\title{
The Hottest Places in Hell: The Catholic Church and Civil Rights in Selma, Alabama, 1937-1965
}

\author{
Gregory Nelson Hite \\ Yonkers, New York
}

B.A., Bates College, 1991

M.A., University of Virginia, 1994

A Dissertation presented to the Graduate Faculty of the University of Virginia in Candidacy for the Degree of Doctor of Philosophy

Department of Religious Studies

University of Virginia

May, 2002




For My Family 


\section{Table to Contents}
Abstract
.. $\quad \mathrm{i}-\mathrm{ii}$
Chapter Summary
iii
Acknowledgements
.. iv-vi
Introduction
$1-12$
Chapter 1: "An Effective Minority."
. $13-48$
Chapter 2: "Patience."
$50-85$
Chapter 3: "The Harvest is Great."
... $\quad 86-129$
Chapter 4: "Heaven."
... 130-156
Chapter 5: "Sanctuary."
.. . $157-178$
Chapter 6: "The Hottest Places in Hell."
... $179-210$
Chapter 7: "Peace Rather than Strife."
- 211-234
Chapter 8: "I Shall Go and See the King.”
$235-279$
Chapter 9: "Outside Agitators."
.. $\quad 280-321$
Chapter 10: "We Shall Overcome."
$322-347$
Chapter 11: "Pilgrimage."
348-396
Bibliography
. $397-408$ 


\section{Abstract}

This dissertation examines the role that Catholics played in the Selma Voting Rights movement between 1962-1965, at both the local and the national level. It assesses the reciprocal impact the Catholic Church and the civil rights movement had upon each other. The goal of this dissertation is to integrate Catholics into the historical narrative of the Selma campaign in particular and the civil rights movement in general. The work traces the history of the Catholic Interracial movement in the United States from its beginnings in the late 1920s through to the rise of the National Catholic Conference for Interracial Justice (NCCIJ) in the early 1960s. The work also explores the growth of the St. Elizabeth's mission in Selma, Alabama 1937-1960.

My aim is to explore how a single religious community brings various physical, economic, political and theological resources, at both the local and national level, to bear upon a grassroots protest movement, and to expand our understanding of the full range of resources the African American community was able to draw upon in the struggle for civil rights. The Selma mission provides a safe haven for the nascent voting rights movement. On March 7, 1965, state troopers brutally assaulted unarmed peaceful protesters and national media was attention riveted upon the city. In answer to a call by Martin Luther King, hundreds of men and women descended upon the city to witness for justice. The NCCIJ mobilized a large Catholic presence to travel to the city and participate in the demonstrations, signaling that the Church was prepared to take its place among the mainstream denominations as an equal partner in the struggle for social justice, and providing the movement with a fresh symbol of Christian witness. 
This dissertation assesses the impact the movement had on the church as it struggled to reappraise its place in a changing America, and the means by which the Black Freedom struggle was able to integrate itself into the American mainstream. How and with what effect these two movements converge at Selma shaped the very nature of the Church and the nation. 


\section{Chapter Summary}

Chapter 1: "An Effective Minority," chronicles the history of the Catholic interracial movement from its beginnings with Daniel Rudd's Colored Catholic Conferences and Turner's Federated Colored Catholics through the rise of Father John LaFarge and the New York Catholic Interracial Council. Chapter 2: "Patience" covers the establishment of the National Catholic Council for Interracial Justice in 1958, and the initial Catholic participation in the emerging civil rights movement, particularly the National Conference on Race and Religion and the March on Washington.

Chapter 3: "The Harvest is Great," explores the founding of the St. Elizabeth's mission in Selma, Alabama in 1937 by the Fathers of St. Edmund to 1960. Chapter 4: "Heaven," details the history of protest activity in Selma from 1930-1960, including the work of the Dallas County Voters' League, the effect of the 1954 Brown v Board of Education decision, the Montgomery Bus Boycott, Sit-ins and Freedom Rides. Chapter 5: "Sanctuary," discusses the entrée of Student Nonviolent Coordinating Committee organizer Bernard Lafayette and the birth of the Alabama Voting Rights Project in 1962. It explores the role the St. Elizabeth's mission played in sustaining the nascent movement. Chapter 6: "The Hottest Places in Hell." Addresses the first two years of the AVRP, 1962-1963 and the establishment of the Alabama Literacy Project in the basement of the St. Elizabeth's mission. Chapter 7: "Peace Rather than Strife," chronicles 1964, the final year SNCC was able to sustain an effective campaign in the city. The chapter explores the various strategies Catholics, white and black, used to deal with the demonstrations with particular emphasis on the relationship between 
Father Maurice Ouellet, S.S.E., pastor of St. Elizabeth's, and Archbishop Thomas J. Toolen.

Chapter 8: "I Shall Go and See the King," examines the entrée of Martin Luther King and the SCLC into Selma in January 1965 and the escalation of demonstrations within and outside the city, the decision to mount a march to the state capital in Montgomery to protest the killing of a demonstrator culminating in "Bloody Sunday," and the assault by state troopers on peaceful marchers on the Edmund Pettus Bridge, March 7, 1965.

Chapter 9: "Outside Agitators," Describes the aftermath of "Bloody Sunday" and the mobilization of massive Catholic participation on the part of NCCIJ as well as the response by the mission to such a large number of Catholic visitors. Chapter 10: "We Shall Overcome," documents the period immediately following "Bloody Sunday," March 8-March 19, and highlights the symbolic and tactical importance of Catholic participation. Chapter 11: "Pilgrimage," describes the final march to Montgomery, March 20-25, Catholic reaction to the demonstrations, particularly to the murder of Viola Liuzzo, and the effects of the march on the Catholic Church and the movement. 


\section{Acknowledgements}

In a project of this size, and especially with one that takes this long, one incurs innumerable debts. I was blessed to have had the strong support of mentors, family, colleagues and friends. I was especially lucky to have a found myself at the University of Virginia where I found not one, but two advisors. Father Gerald Fogarty and Dr. Heather Warren have guided me over the past nine years as I strove to become a better scholar, teacher and person. I am forever indebted to them both for the time, wisdom, and trust they invested in me.

I met David Garrow in 1990 while a senior at Bates College. For over a decade, he has served as a mentor and has been kind enough to share his insights with me at every stage of my career and this project. I am deeply grateful to him for his advice. Professors Wallace Best and John Mason have been unflagging sources of support and encouragement to me throughout the process. Both Father Joseph McLaughlin, S.S.E., and Dr. Steven Longenecker graciously shared with me their knowledge and insight.

Much of this work is based upon hours of personal interviews. I offer my sincere thanks to the Fathers of St. Edmund, Sisters of St. Joseph, the parishioners and staff of the St. Elizabeth's mission, the men and women of the diocese of Mobile, the people of Selma, all of those who traveled to Selma, as well as those who had other parts to play. All shared their time, their stories and their passion with me. I hope that I have I done justice to the story with which they have so carefully entrusted to me.

I have had the pleasure and honor of working with numerous special collections across the country. Archbishop Oscar Lipscombe of Mobile served as chancellor under Archbishop Toolen in 1965. He allowed me complete access to the diocesan archives. 
His vote of confidence inspired me to tackle the more difficult aspects of the project. I offer my thanks and appreciation to John Shepherd at the Catholic University of America, Phil Runkel at the Marquette University, Tom Gino and Pauline Giancoloa at Edmundite Archives at St. Michael's College, the Society of St. Edmund Archives at St. Michael's College, Alston Fitts at the St. Elizabeth's mission archives in Selma, Sister Jean Agnes Michaud, S.S.J., and Kathy Urbanic at the Sisters of St. Joseph Archives at the Motherhouse in Rochester, Kevin Cawley at the University of Notre Dame Archives, and Jim Bagget at the Birmingham Public Library. The staffs at the Amistad Research Center, the Chicago Historical Society the Chicago Archdiocesan Archives, Georgetown University Special Collections, and most importantly at the librarians at the University of Virginia were always kind, helpful and supportive of the project.

I would like to thank the Department of Religious Studies at the University of Virginia. Their generosity allowed me to complete the project. There is one historical truth everyone must recognize: the office staff is the small cog around which the universe revolves. I thank all of the departmental secretaries for their help, encouragement and assistance: Dianne, Linda, Doug, and especially Fonda, thank you. I would also like to thank Dean Robert Huskey for his support over the years.

All the residents of the fun house who when they signed their lease unknowingly joined me on this project. Thank you for dropping me off at the library, abducting me from the library, and, in both cases, watching the dog while I was gone. I thank all the people who I have had the pleasure of working with for the last two years at the South Street Brewery. You provided me not only with friendship, love and support, but a safe place, away from books and school, to work, think and relax. To all my friends, colleagues and teammates in Charlottesville and elsewhere: thank you. I cannot 
possible offer enough thanks to all who have helped me, but a few deserve special mention: Leslie Urofsky, Jeff Earl, Michael Utzinger, Trent Pomplun, Brian Philips, Kristine Lalonde-Mosse, Wes Sechrest, Scott Tobler, Jacquie Bussie, Kelly Mezic, Anne Armstrong, David Hoch, Claiborne Fogleman, John Marone, and Fred Greenewalt. Your friendships have meant more to me than you can possibly imagine.

And finally to my family. The debt that I owe to you all is incalculable. Thank you for your love, support, encouragement and the occasional threat. Thank you for taking me in, and more importantly understanding when I could not be with you-know that I thought about you all at every turn. I dedicate this project to you. 


\section{Introduction}

The 1965 Selma demonstrations are a watershed event in the history of the American civil rights movement. The campaign was the culmination of a number of struggles: the Brown decision, the Montgomery Bus Boycott, the student-led Sit-ins, the Freedom Rides, the demonstrations in Albany and Birmingham, the March on Washington and "Freedom Summer." By 1965, the violence inherent in the segregated South had been made clear to the American public. The media, in particular television, played a crucial role by depicting the brutality that protesters received at the hands of violent segregationists. The Voting Rights Act of 1965, signed into law partly as a result of the intense media scrutiny and public support generated by the campaign, ended white domination of elections. It allowed hundreds of black men and women to win city, county, state and federal offices across the South, and reshaped the national political landscape.

After the demonstrations, the cry "Freedom Now" was replaced with "Black

Power." The goals of the movement shifted from attaining the beloved community to reaping the benefits and struggling with the unintended consequences of the end of segregation. Finally, the campaign marked the end of the Southern phase of the civil rights movement. Selma was the last archetypal confrontation between the violent forces of segregation, symbolized by Dallas County Sheriff Jim Clark and his posse, and a united, nonviolent, 
ecumenical and integrated community. The following year Martin Luther King and the Southern Christian Leadership Conference moved North to mount a campaign in Chicago, and the problem of racial discrimination could no loner be viewed as a particularly Southern phenomenon.

The Selma demonstrations also mark the entrée of the Catholic Church into the civil rights movement. At Selma, Catholic activists on both the local and national scene converged to play important roles in the campaign. After Selma, Catholics became leaders in a number of activist causes in the late 1960s marking the rise of the "New Catholic Left." The story of the Catholic Church's participation in the American civil rights movement has not fully been told. This dissertation seeks to explore the role that Catholics played in the Selma Voting Rights movement at both the local and the national level, and to assess the impact that the reciprocal impact that the Church and the civil rights movement had upon each other.

From its earliest days the Catholic Church had been entangled in the racial question. But for the most part limited her ministry to educational endeavors and worked within the system of segregation. The Catholic Interracial movement was initiated by a small group of African American Catholic laity and white clergy in the early part of the $20^{\text {th }}$ century. Father John LaFarge, S.J., became the Church's preeminent spokesman on race. LaFarge espoused a theology which declared the universal brotherhood of all. He established a national network of 
organizations and individuals dedicated to the cause of interracial justice. In 1927 he founded the New York Catholic Interracial Council. By the 1960s there were CICs in every major city in the North.

From the beginning, the Catholic Interracial movement struggled with the issue of authority. The lack of involvement by Catholics was partly due to restrictions against ecumenical undertakings, as well as Catholics' own sense of mission. For the most part Catholics remained focused on reforming the Church. Black laity, however, saw the movement as an opportunity to pressure the hierarchy for reform in both the Church and the nation. White clergy were reluctant to press the hierarchy and opted for a less confrontational approach that stressed education. The relationship between black laity and white priests was often extremely tense, and friction undermined a number of early reform efforts. Another reason for limited Catholic involvement was that Catholic clergy and religious were unable to react quickly to the rapidly developing events of the 1950s and 1960s. There existed in the Church a long tradition of asking the local bishop's permission to perform a public act in his diocese. The lack of prominent black Catholic leadership and the tepid approach of the clergy regarding the race issue hampered the movement and relegated it to the sidelines as the Southern freedom struggle emerged.

Like the rest of the nation, however, the Church in the 1960s was entering a new era. Catholics were beginning to experience a feeling of independence that 
liberated them from the status of a marginalized religion. The Church was no longer an immigrant Church; Catholics were confident in their patriotism and their sense of belonging in America. The election of Kennedy to the nation's highest office proved beyond a doubt that Catholics were entering an age of open participation in all facets of public life. But not all Catholics found themselves in the same situation. As Edward Kantowictz has noted:

The leaders of big city Catholicism set the tone for the American Church. In rural areas and in large parts of the South and West (what Catholics called "no-priest land."), Catholics remained either invisible or apologetic, but in the larger cities of the Northeast and Midwest, Catholic leaders visibly threw their weight around in an attempt to instill self-confidence in their flocks."1

Unlike their fellow Catholics in the North, Southern Catholics adopted very different strategies to negotiate the issue of race. As Catholics in a Protestant milieu, they adopted very different strategies to secure their place in society. White Southern Catholics vigilantly maintained segregation in their homes, businesses and parishes so that they might enjoy the benefits of being white. In doing so, they relegated their black Catholic neighbors to a double outsider status in a region dominated by white Protestants.

In 1958 the Catholic Interracial activists reassessed their strategy of promoting interracial justice. CIC delegates founded the National Catholic Council for Interracial Justice (NCCIJ) in order to facilitate a broader engagement with the Church and the country. The rise of the NCCIJ signaled a new era of 
Catholic engagement in social issues, especially by Catholic laity. In 1963 two major events occurred: the NCCIJ participated in the National Conference on Race and Religion and the March on Washington. Both were seminal events for Catholic interracial activists. These events introduced Catholic activists to the philosophy of nonviolence and basic community organizing techniques and enabled them to create an important network of contacts with major civil rights organizations and leaders. More importantly, the rise of the NCCIJ established an institutional framework that would enable activists to muster a large Catholic presence on short notice. Prior to 1965, the Catholic Interracial movement simply did not have the institutional resources in place to coordinate such a massive undertaking.

Catholic scholars have brought to light the long and difficult history of the Catholic Interracial movement, but there is a major gap in the historiography. Those who have examined the issue of race in more detail such as Martin A. Zielinski in "Doing the Truth," Andrew Moore in, "Catholics in the Modern South," Cyprian Davis in The History of Black Catholics, Stephen Ochs in Desegegating the Altar, Mary Nichols in, Black Catholic Protest and the Federated Colored Catholics, John McGreevey in Parish Boundaries, and David Southern in The Limits of Catholic Interracialism have touched on Catholic participation in the civil rights movement, but none have addressed Catholic participation in nonviolent

\footnotetext{
${ }^{1}$ Edward Kantowitcz. "Cardinal Mundelein and the Shaping of Twentieth Century Catholicism."
} 
direct action campaigns at the local level. ${ }^{2}$ The focus of these works has almost exclusively been on the educational efforts of the interracial movement to address the issue of interracial justice among Catholics. Leslie Tentler highlighted the failure of Catholic historians to examine how Catholics have engaged with issues outside of the Church. Historians, Tentler noted, "seldom ask how Catholics have affected American society and culture."3 This work is an attempt to bridge the gap between Catholic and civil rights movement scholarship.

Aldon Morris's The Origins of the Civil Rights Movement signaled a decisive shift in how the movement was understood and highlighted the importance of examining the local resources a community drew upon to organize for social and political change. Morris posited, "[communities] were responding through established organizations and developing lines of communications." 4 Over the last decade, civil rights scholars have examined numerous campaigns at the grassroots level such as John Ditmer in Local People and Charles Payne

The Journal of American History v. 68 n.1 (1981) 55.

2 Cyprian Davis, The History of Black Catholics in the United States, (Crossroads: New York, 1993), 256-7. John McGreevey, Parish Boundaries: The Catholic encounter with Race in the Twentieth Century Urban North, Chicago University Press: Chicago: 1996), 155-158 [Note: McGreevey cites my own M.A. thesis, University of Virginia, 1994, in his work on Selma], David Southern John LaFarge and the Limits of Catholic Interracialism,

3 Leslie Tentler, "On the Margins: The State of American Catholic History," American Quarterly, March 1993, 115.

4 Aldon Morris. "Black Southern Sit-In Movement: An Analysis of Internal Organization." American Sociological Review v. 46 Issue 6 (December 1981) 744-767. And Aldon Morris. Origins of the Civil Rights Movement. And Doug McAdam, Freedom Summer, (Oxford University Press: New 
in l've Got the Light of Freedom. However, Catholic participation remains unexplored in these narratives as well. Catholics do not fit into the traditional picture of Southern black Protestant activists and Northern white, liberal, Jewish and Protestant supporters. Where Catholics are mentioned, the references are often brief and without context. A Catholic participant is either considered an individual acting on his or her own or the minion of a monolithic Roman Catholic Church. ${ }^{5}$

A few scholars have begun to bridge the gap between the fields of American religious history and movement history, most notably James Findlay in Church People in the Struggle, Steven Longenecker in Selma's Peacemaker, David Chappell in Inside Agitators and Charles Marsh in God's Long Summer. In a 1998 article Marsh wrote:

We should work hard to understand the rich and complex legacy of those local men and women who believed that God was really there, in the thick of things, working mightily toward a more just society. ${ }^{6}$

It is imperative, if we are to truly understand how movements grow and develop, that we address all of the resources that the African American community drew upon to challenge the status quo in the South.

York, 1988) and Political Process and the Development of Black Insurgency, 1930-1970 (University of Chicago Press: Chicago, 1982)

${ }^{5}$ Andrew Greely. "The Sociology of American Catholics." Annual Review of Sociology v.5 (1979) 91.

${ }^{6}$ Charles Marsh. “Jesus in Mississippi.” Books and Culture March/April 18, 1998. 12. 
The historiography of the Selma movement itself illustrates the problems Catholic involvement presents. James Hennessey's American Catholics does not mention Selma. Jay Dolan and Cyprian Davis, O.S.B., both mention the demonstrations in their respective histories, but offer only a brief summary of the events. Dolan writes:

The 60s was a decade of sit-ins and protest marches. Certainly one of the most significant took place in Selma, Alabama in March 1965, when thousands of people walked from Selma to Montgomery to demonstrate for the rights of blacks to vote. Clergy of all religions took part in this demonstration; over four hundred Catholic priests, nuns, brothers and lay people walked together with blacks and whites, Protestants and Jews, publicly demonstrating on behalf of civil rights for blacks. To be out on the front line publicly demonstrating for social justice was something new for Catholic priests and religious. Eventually a priest or nun standing on a picket line or participating in a protest march became quite a common site. ${ }^{7}$

David Garrow's Protest at Selma and Charles Fager's Selma, 1965 offer the most complete account of the movement. However, Garrow is more concerned with the legislative battle waged in Washington over the Voting Rights Act rather than an analysis of the local activism. Charles Fager served on the Southern Christian Leadership Conference staff in 1965. His account highlights SCLC's role in the Selma movement. Neither account explores to a great extent the efforts of the Student Nonviolent Coordinating Committee in 1961 or any prior local efforts. Both briefly mention Catholics, but do not explore the subject in detail. Stephen Longenecker's Selma's Peacemaker examines the role of 
Church of the Brethren minister Ralph Smeltzer and his efforts at community mediation. It is the most in depth account of the movement and offers a glimpse of the Catholic presence in Selma. Amelia Platts Boynton Robinson's Bridge over Freedom and Charles Chestnutt's Black in Selma are helpful in contextualizing the role Catholics played in the community. None of the present accounts properly explores the impact of the black Catholic community in Selma.

The history of the St. Elizabeth's mission is an essential component of the history of the city of Selma. Founded in 1937 by missionaries from the Society of St. Edmund, a small Catholic religious order in Winooski, Vermont, the mission ran an elementary school, the only black hospital in the county, a school of practical nursing, a retirement home, a boys and girls club, oversaw numerous satellite missions from offices in the city, and played a prominent role in establishing a credit union. The Good Samaritan Hospital, run by the Sisters of St. Joseph of Rochester, New York, and the Mission's business offices were one of the largest employers in the city employing black men and women regardless of denominational affiliation. The mission also provided local children with educational opportunities by arranging scholarships to Catholic colleges around the nation. The Fathers of St. Edmund, the Sisters of St. Joseph and the parishioners of the St. Elizabeth's mission labored to create a vibrant Catholic

7 Jay Dolan, The American Catholic experience; A History from Colonial Times to the Present, (University of Notre Dame Press: Notre Dame, 1992), 445. See also Cyprian Davis, History of Black Catholics, 256-7. 
community within the strict confines of segregation. Unlike Catholic interracialists in the North, they were not concerned with a theoretical defense of interracialism, but with the practical needs of their parishioners.

By 1960 the mission began to serve as a haven for protest activity and bulwark against hostile white intimidation. Although Catholics made up a small percentage of Selma's black community, they played a role in the movement far greater than their numbers suggest. Despite the antipathy of Archbishop Thomas Toolen towards demonstrations, St. Elizabeth's pastor, Father Maurice Ouellet, S.S.E., supported SNCC's initial efforts in the city when no other Church would. The religious, economic and social resources of the mission allowed SNCC organizers to initiate the Alabama Voting Rights Project (AVRP) in 1962. Toolen's objections to the demonstrations and the public reaction to his stance offer an indication as to the extent Catholics were beginning to break out of traditionally conservative roles and to publicly engage in the social revolution sweeping the country.

Parishioners, priests, nuns and staff worked with SNCC staff members to challenge the restrictive voting laws. Despite their efforts the campaign produced few victories, and, after two years, the movement floundered. In 1964 a coalition of local leaders invited Martin Luther King and SCLC to revitalize the campaign. SCLC arrived in January of 1965 and began organizing marches throughout the city, eventually expanding the scope of the movement to include nearby towns. 
Despite the presence of Catholics in the campaign and the emergence of the NCCIJ onto the national scene in the early 1960s, Catholics around the country were not drawn to participate in the Selma Voting Rights Campaign. All that changed on March 7, 1965. The image of state troopers visciously beating unarmed black demonstrators on the Edmund Pettus Bridge and Martin Luther King's "Macedonian call" for clergy of goodwill inspired men and women to travel to Selma and participate. Within days, the NCCIJ had mobilized its affiliates throughout the nation and mustered over nine hundred Catholics -- clergy, religious and laity. The St. Elizabeth's mission provided food and housing for visitors. The Selma demonstration was the culmination of the Catholic Interracial movement's attempt to involve the Church in the struggle for interracial justice. It highlights the critical importance of both local and national structures of the Church in enabling Catholics to successfully engage in social protest.

At Selma the national media picked up on Catholic participation as newsworthy. Catholics had been extremely self-conscious of themselves as outsiders in a Protestant world and had often avoided confrontations with the status quo for fear of inviting economic, political and social retribution. For the first time the Church was publicly aligned with the nonviolent direct action civil rights movement. The Catholic Church provided the campaign with a fresh new symbol of Christian witness, particularly in the case of women religious. The massive influx of Catholics infused the campaign with a renewed sense of moral 
legitimacy, as the last of the mainstream American Churches aligned itself with the struggle for equal rights.

However, there was no mass conversion to the cause of social justice within the Church. Most participants were CIC members and had been involved in the interracial apostolate for years. Instead, Selma signaled a new style of Catholic engagement in social justice. The profound change in public opinion forced many in the Church to question what role Catholics should play in the social revolution that was erupting in the South. At that time, numerous bishops and religious superiors radically changed their opinions about whether clergy should be allowed to participate in nonviolent demonstrations. However, the participation of Catholics revealed internal tensions within the Church. By not seeking permission from the local archbishop, clergy and religious freed themselves to follow their consciences as individuals and became involved in whatever cause they felt demanded their attention wherever that cause might require them to be. After Selma clergy and religious became actively involved in national causes on a scale never before seen, and both SCLC and SNCC struggled to incorporate their new partners effectively into the movement.

The goal of this dissertation is to integrate Catholics into the historical narrative of the Selma campaign in particular and the civil rights movement in general. My aim is to explore how a single religious community brought physical, economic, political and theological resources, at both the local and national level, 
to bear upon a grassroots protest movement. I seek to expand our understanding to include Catholics as part of the full range of resources the African American community was able to draw upon in the struggle for civil rights. At the same time I assess the impact that Catholic participation in the movement had on the Catholic Church as it struggled to reappraise its place in a changing America and the means by which the Black Freedom struggle was able to integrate itself into the American mainstream. 


\section{Chapter 1 :"An Effective Minority"}

"The only true difficulty in realizing Catholic ideals is simply the lack of persons with sufficient spiritual caliber to form an effective minority."

John LaFarge

The Catholic Interracial movement was initiated by a small group of African American Catholic laity and white clergy in the early part of the $20^{\text {th }}$ century. From its beginning the movement struggled with the issue of authority. Black laity saw the movement as an opportunity to pressure the hierarchy for reform of both the Church and the nation. White clergy were reluctant to press the hierarchy and opted for a less confrontational approach that stressed education. The lack of a prominent black Catholic leadership and the tepid approach of the clergy regarding the race issue hampered the movement, and it was relegated to the sidelines as the Southern freedom struggle developed.

The major issue facing the Catholic Church in America at the beginning of the twentieth century was how to assimilate the massive numbers of ethnically diverse European Catholics who had immigrated to the United States over the prior fifty years. Succeeding waves of Irish, Germans, Italians and Poles threatened to overwhelm the institutional and theoretical resources of the Church as it struggled to provide for their material, social, political and spiritual well being. Simultaneously, Catholic leaders were forced to fend off nativist attacks and maintain peace between the various Catholic enclaves that sought to 
maintain their distinct ethnic heritages. The locus of these struggles was the urban North. The majority of Catholic immigrants settled along the industrialized corridor stretching west from New York to Chicago. While some groups, most notably the Germans, settled in scattered rural communities in the Midwest, most remained in concentrated urban neighborhoods. ${ }^{1}$

Ethnicity, not race, was the primary factor in determining social identity for the vast majority of American Catholics. Most African Americans lived in the South and there were few opportunities for these newly Americanized Catholic immigrants to interact with blacks. The race problem was a problem for the South to address, and Southerners were seen by Catholics as Protestant and anti-Catholic. ${ }^{2}$ But there were a small number of African American Catholic communities in the South, most notably in Maryland, Kentucky, and Louisiana. ${ }^{3}$ A small number of Catholic religious orders worked among American blacks. ${ }^{4}$

\footnotetext{
1 Davis, Black Catholics, 195-237and McGreevey, Parish Boundaries, 9. Other general histories that address the diverse ethnic make up of American Catholicism are: Dolan, American Catholic Experience, James Hennesey, American Catholics: A History of the Roman Catholic Community in the United States (New York: Oxford University Press, 1981). Also Delores Liptak. Immigrants and Their Church (New York: Macmillan Press, 1989).

${ }^{2}$ McGreevey, Parish Boundaries, 8.

${ }^{3}$ Maryland was founded by Catholics, and many Catholic slave owners converted their slaves. Many Catholic Marylanders migrated west into Kentucky taking their slaves with them. Louisiana had a long history as a Catholic, first French and then Spanish, colony before becoming a part of the United States. All three have substantial black Catholic communities.

4 See Davis, Black Catholics, "Christ's Image in Black: The Black Community before the Civil War." 67-97, "Builders of Faith: Black Religious Women before and after the Civil War," 98-115, and "A Golden Opportunity for a Harvest of Souls: The Second Plenary Council of Baltimore, 1866," 116-144. The Oblate Sisters of Providence, founded in Baltimore in 1829, were the first religious order of African American women in the United States. They dedicated themselves to establishing schools for orphan women of color. The Sisters of the Holy Family were founded in New Orleans in 1842 and educated and ministered to the city's poor. In 1872 the Congregation of the Holy Ghost, or Spiritans, sent missionaries to the United States and set up parishes in African American neighborhoods in Pittsburgh. The St. Joseph Society of the Sacred Heart for
} 
Despite the work of these orders, however, and the limited efforts of diocesan priests, African American Catholics made up a minute part of the Church. The racial issue, like black Catholics themselves, existed at the margins of the Catholic intellectual and cultural world.

The Vatican made a number of inquiries into the plight of African Americans, particularly African American Catholics. The American hierarchy held the Second Plenary Council in Baltimore in 1866. Archbishop Martin Spalding of Baltimore proposed to Rome that the bishops address how they planned to deal with the recently emancipated slaves. Spalding suggested three options: the establishment of separate black parishes, the use of missionaries and the appointment of a national coordinator to supervise work among African Americans. He saw the Council as a "golden opportunity for reaping a harvest of souls, which if neglected may not return." 5 Rome approved the agenda for the meeting, but the American hierarchy had been seriously divided over the question of slavery. Rather than confront the issue, the council meekly decreed that it hoped that "all who administer the sacraments might be present to all who seek them."6 The council formulated no plan to address the question of black evangelization. Instead, the bishops agreed to care for the needs of African Americans in their respective dioceses individually.

Foreign Missions, or Josephites, had dedicated themselves to prostylatizing among African Americans in 1893.

5 Stephen Ochs, Desegregating the Altar: The Josephites and the Struggle for Black Priests, (Baton Rouge: Louisiana State University Press, 1990), 39.

6 Davis, Black Catholics, 120. 
Black Catholic laymen, while a minority, were by no means silent regarding their status in the Church or the nation. By the close of the $19^{\text {th }}$ century, they had organized to press for equal rights. Daniel Rudd, a successful black Catholic businessman from Springfield Ohio, published the American Catholic Tribune. He believed that the Catholic Church offered the best hope for African Americans to achieve their full civil rights in the United States. "The Holy Roman Catholic Church," Rudd wrote, "offers to the oppressed Negro a material as well as a spiritual refuge, superior to all the inducements of other organizations combined."7 The first Colored Catholic Congress (CCC) was held in 1889 in Washington D.C. Over two hundred delegates from across the country met to address the issues facing them and to press the hierarchy for reform. Recognizing the importance of education to the religious, economic and social well being of black Catholics, they demanded access to parochial schools, Catholic higher education and seminaries, as well as the establishment of a black clergy. Nor did the delegates limit their concern to purely spiritual matters. They urged labor unions to accept black members and businesses to employ blacks. In order to care for the most disadvantaged, the congress called upon the Church to establish orphanages, hospitals and asylums. The congresses were held annually until 1895. By the fifth and final congress, the tone of the organization's demands had become more militant and the group's relationship with the hierarchy increasingly strained. The delegates pressed for an end to all legal

\footnotetext{
${ }^{7}$ Rudd quoted in Ibid, 165-166.
} 
discrimination and continued to lobby the Church for the ordination of African American priests. ${ }^{8}$

In 1904 Pius X wrote to Archbishop Diomede Falconio O.F.M., the Apostolic Delegate to the United States, to state:

It has been referred to this Sacred Congregation that in some of the diocese of the United States the condition of the Catholic Negroes, not only in respect to the other faithful but also in respect to their pastors and bishops, is very humiliating and entirely different from that of whites. ${ }^{9}$

Pius $\mathrm{X}$ admonished the American hierarchy, noting this treatment was "not in conformity with the spirit of Christianity, which proclaims the equality of all men before God."10 In 1907 the bishops established the Commission for Indian and Negro Missions in order to fund evangelization efforts. However, in a letter to Rome, Archbishop Michael Curley summed up the reaction of the hierarchy. Curley implored the Vatican to understand that the American Church's relationship to African Americans was a result of the "the keen race distinctions which the Catholic Church has not made and cannot solve."11

In 1917 Dr. Thomas Wyatt Turner, a black Catholic professor of biology at Howard University, reinvigorated the black Catholic lay movement. Turner was a member of St. Augustine's Church in Washington D.C. and he organized an

\footnotetext{
8 Ibid, 163-194.

9 Ibid. 195-6. Davis notes that the Vatican's interest was aroused as a result of a confidential pamphlet entitled The Miserable Conditions of Black Catholics in the United States, circulated in Rome by Joseph Anciaux, S.S.J. a year earlier.

10 lbid, 195.

11 Ochs, Desegregating the Altar, 237-8. The Commission on Negro and Indian Missions was established in 1884 by the Third Plenary Council of Baltimore. Ochs, Desegregating the Altar, 6.2Later it was reorganized
} 
informal meeting of African American Catholics to discuss the racial conditions within and practices of the Church. These informal meetings developed into the Committee Against the Extension of Race Prejudice in the Church. Two years later the group's name was changed to the Committee for the Advancement of Colored Catholics. Turner planned to use the organization as a springboard to petition the Catholic hierarchy for a redress of grievances. ${ }^{12}$ By 1924 the small Washington based committee had evolved into a national organization of African American Catholic laymen dedicated to promoting the cause of racial justice within the Church. Turner renamed the organization the Federation of Colored Catholics (FCC) and declared that its "sole purpose was to weld [African American Catholics] into a solid unit for race betterment."13 He chastised the bishops for their failure to provide for the spiritual well being of black Catholics, and his tone echoed that of his predecessor Rudd. Turner emphasized Catholic teachings on the equality of all men in Christ, the necessity of a Catholic education for members of the faith, and the immense potential for conversion among African Americans. ${ }^{14}$ He defended the necessity of the new organization by reminding the bishops that the cost of their actions was the souls of his people. He declared:

\footnotetext{
12 Mary Nichols, "The Federated Colored Catholics: A Study of Three Variant Perspectives on Racial Justice as Represented by John LaFarge, William Markoe and Thomas W. Turner," (Ph.D. Dissertation: Catholic University of America, 1975), 2.

13 McGreevey, Parish Boundaries, 31.

14 Cf: Leo XIII's Rerum Novarum and Pius XI's Quadragesimo Anno for the Church's teachings on social justice.
} 
If the color of his skin outweighs every other consideration in the white Catholic mind, then the more completely the spiritual and material accumulations of the race are fused on that basis, and the greater will be his protection and his progress. And thus, in the United States, we have the sad spectacle of colored people being driven in conversion to Protestantism through the inaction of the Church authorities. ${ }^{15}$

Foremost on his list of demands were increased access to Catholic colleges, universities and parochial schools and the training and ordination of African American clergy.

In 1925 two Jesuits, Father John LaFarge and William Markoe joined the FCC and served as the organization's chaplains. LaFarge was born into a wealthy Newport, Rhode Island family in 1880. His Father was a well-known artist, renowned for his murals and stained glass work. ${ }^{16}$ LaFarge was educated at Harvard and Innsbruck. He was ordained in 1905 and entered the Society of Jesus. ${ }^{17}$ In 1911, due to his poor health, LaFarge was assigned to St. Mary's County in Maryland. For fifteen years LaFarge experienced first hand the plight of African Americans living in the rural South. Completely unfamiliar with the social mores of Jim Crow, the young priest recounted his complete surprise when he realized that merely treating a black person as a human being resulted in severe social consequences for the crime of "moving the Negro 'out of his

\footnotetext{
15 Mary Nichols, "Black Catholic Protest and the Federated Colored Catholics: 1917-1933 (New York: Garland Press, 1988), 51. My emphasis.

16 John LaFarge senior is best known for designing the stained glass at Trinity Church in Boston and St. John the Divine in New York City.

17 Most of the information on John LaFarge is taken from his autobiography. Cf: John LaFarge, The Manner is Ordinary (New York: Harcourt and Brace, 1967). See Also Peter McDonough, Men Astutely Trained: A History of the Jesuits in America. (New York, The Free Press, 1990), McGreevey, Parish Boundaries, David Southern, John LaFarge and the Limits of Catholic Interracialism, 1911-1963, (Baton Rouge, Louisiana State University Press, 1996).
} 
place."'18 LaFarge struggled to provide for the spiritual and material needs of his parishioners. The segregated public schools for African Americans in Southern Maryland were atrocious. The schools were open for only four months of the year and attendance was optional. LaFarge set about establishing parish schools, and in 1916 became involved in the Cardinal Gibbon's Institute. ${ }^{19}$ The school was founded as a national Catholic interracial academy and was modeled on Booker T. Washington's Tuskegee Institute. LaFarge envisioned the school as a place, which would provide vocational education for deserving young African Americans in a strong Catholic environment, as well as health and agricultural resources for the local black community. ${ }^{20}$ Cardinal James Gibbons of Baltimore gave $\$ 8,000$ to purchase the land for the school, but it took a few years to raise enough money to build and staff the school. It was through his work with the school, that LaFarge met Dr. Turner. Turner and the FCC were involved in the early stages of the Institute's planning and raised funds for the project. ${ }^{21}$ The school was opened in the fall of 1924 . The principle of the school was Victor Daniel, an alumnus of Tuskegee and a faithful Catholic. Together with his wife, Constance, Daniel ran the school, its farms and community outreach programs. They reported to a board of directors made up almost entirely of white Catholic

\footnotetext{
18 Southern, Limits of Catholic Interracialism, 29. LaFarge, Manner, 190.

$19 \mathrm{lbid}, 33$. LaFarge established two parish schools; two for blacks and two for whites during his tenure in Southern Maryland. The schools were located in St. James and Ridge, Maryland. 20 On the history of the Cardinal Gibbons Institute see Cecelia Moore's dissertation. Cecelia Moore, "A Brilliant Possibility: The Cardinal Gibbons Institute, 1924-1934." (Ph.D. Dissertation: University of Virginia, 1997).

$21 \mathrm{lbid}, 39$.
} 
laymen and clergy and appointed by Gibbon's successor in Baltimore, Archbishop Michael Curley. ${ }^{22}$

Fundraising was difficult as the school was never a priority among Catholic or African American donors, and the school suffered severe fiscal difficulties during the lean years of the Depression. ${ }^{23}$ In addition to financial problems, the relationship of the Daniels and the board of directors became increasingly strained. The Daniels resented the interference of the absentee board in the day-to-day operations of the school, and had substantial disagreements with the board over the Institute's educational philosophy. The Daniels stressed a liberal arts education in addition to vocational training, a policy that many on the board opposed. Board members, particularly those who were priests and prelates, resented what they saw as the arrogance of the Daniel. In part the conflict was the result of clerical antipathy toward lay initiative and partly because of the board's unwillingness to submit to black leadership. Constance Daniels, in a stinging letter to LaFarge in 1925, declared, "If race and creed clash, creed will have to go. I am a Negro first."24 After a seven-year struggle, the Cardinal Gibbon's Institute closed in 1933.

LaFarge's reply to Constance Daniel's concerns is indicative of his understanding of the Church's role in achieving interracial justice. For him

22 Southern, Limits of Catholic Interracialism, 35-36.

23 The Third Penary Council of Baltimore in 1884established the Collection for Negro and Indian Missions, however the collection proved to be unable to sustain any serious mission efforts. In 1907 the hierarchy, at the urging of Mother Katherine Drexel, created the Commission for Negro and Indian Missions. 
appealing to race could not solve the race problem. What was required was an appeal to, and a grounding in, a transcendent, supernatural body, the Roman Catholic Church. Outside of the Church, LaFarge held little hope of overcoming the race problem, and despite the difficulties of implementing reform he boldly asserted to Mrs. Daniel, "the Church, from her intrinsic holiness, infallibly renders justice in the end." 25 LaFarge made a clear distinction between the eternal principles of the sinless Church and the failure of prejudiced Catholics to implement those teachings. His approach rested on an assumption that if Catholics, particularly white Catholics, were presented with those eternal principles, the race problem would eventually be solved. The issue then was not, as John McGreevey notes, "Catholic racialism in theory but Catholic racialism in practice."26

LaFarge hoped that by educating clergy and laymen, an effective leadership corps could be developed which would spread the doctrine of racial justice throughout the Church. In 1929 he wrote:

It is the minority, which ultimately settles things. The only true difficulty in realizing Catholic ideals is simply the lack of persons with sufficient spiritual caliber to form an effective minority. The real work will be done, as always, by men and women who will devote to the task their personal service. ${ }^{27}$

24 Southern, Limits of Catholic Interracialism, 41.

25 Ibid.

26 McGreevey, Parish Boundaries, 33.

27 LaFarg,e “Opportunity for the Negro," America (2 February, 1929), 407. 
This "effective minority" would be firmly grounded in the teachings of the Church. "Accomplish this immediate task," wrote LaFarge, "and I believe that the more difficult problem of the clergy will solve itself as a matter of course."28

Believing that protest was an ineffective strategy for reform, LaFarge consciously rejected a more militant approach in addressing racism in the Church. In 1930 Father John Gillard, S.S.J. sent Lafarge a copy of his doctoral dissertation The Catholic Church and the American Negro. LaFarge was unimpressed with the Josephite's work and harshly criticized the piece for its depiction of blacks as childlike and oversexed. What is revealing, however, is LaFarge's reaction to Gillard's remark that his work would probably "irritate" some people. "I doubt if much is achieved by irritation," LaFarge replied, "In the long run I think more is accomplished by pacific methods."29 For LaFarge, the entire Catholic interracial movement was a spiritual endeavor, not a political one.

LaFarge concentrated his efforts on the clergy and key laymen rather than attempt to build a broad coalition of grassroots Catholic support. LaFarge argued, "Direct contact with the masses of the people was strategically inefficient. This tactic was a poor investment that yielded little in return for the time it consumed." 30 To some extent LaFarge's narrow focus on such a small group of Catholics was due to his desire to maintain control over the movement. His authoritarian style however was also tinged with paternalism, and he remained

\footnotetext{
28 LaFarge, "The Immediate Negro Problem" America (December 24, 1921), 222

29 Southern, Limits of Catholic Interracialism, 118.

${ }^{30} \mathrm{LaFarge}$ quoted in McDonough, Men Astutely Trained, 125.
} 
isolated from the majority of interracial leaders, most of whom were nonCatholics, due to restrictions on cooperation those outside the Church in place at the time. In 1926 he was made an editor of the national Jesuit weekly, America. ${ }^{31}$ While the magazine provided him with a new forum in which to discuss the race question, LaFarge still hoped to create an organization that would be dedicated to promoting the issue of racial justice in the Church.

After moving to New York, LaFarge turned his attention to Dr. Turner and the Federated Colored Catholics. "The possibilities for good," wrote LaFarge before joining the FCC, "not merely for the Negro himself, but for the Church at large, of a solid union of all American colored Catholic . . . are not to be overlooked."32 Although two white Jesuits served as the group's chaplains, lay membership was restricted to African Americans. LaFarge was concerned that an organization that restricted its membership along racial lines could not serve as an appropriate vehicle for Catholic teaching. LaFarge strongly believed the Church's racism could only be overcome by the application of the Church's teachings, which for him were exemplified in the unity of all in the mystical body of Christ. It was the Church's claim to universality that provided the Church with "its most passionate claim to ascendancy." 33 According to LaFarge, the FCC had to serve as a model of interracial cooperation to the larger segregated Church. LaFarge demanded that the organization reflect Church doctrine regarding the

31 Southern, Limits of Catholic Interracialism, 83.

32 LaFarge, "Full Measure for the Negro," America (December 24, 1921), 198.

33 LaFarge, "The Crux of the Negro Problem," in America (November 6, 1926), 80. 
unity of all men in Christ. He wanted no part of what he viewed as a Jim Crow organization. In order to safeguard the organization, Lafarge believed the group needed to be placed under his supervision. Strict clerical supervision was also required by the bishops for any organization which wished to identify itself as Catholic. ${ }^{34}$ Turner was committed to the FCC remaining a black organization under the direct control of laymen. He was convinced that the Church would never alter its policies unless it was pressured to do so. In addition, LaFarge felt that the immediate goal of ending racism should in no way jeopardize the advancement of the faith. The two key issues that derailed the Cardinal Gibbon's Institute, lay leadership and black militancy, resurfaced and would eventually end in a bitter struggle for control of the FCC in 1932.

William Markoe, LaFarge's ally in the FCC, was originally from St. Paul, Minnesota, and entered the seminary in St. Louis in 1912. Like LaFarge, Markoe was from a distinguished family, but there the similarities ended. LaFarge was bookish and reserved, whereas Markoe was confrontational and charismatic. The former was most comfortable at his editor's desk, while the latter flourished as a parish priest. ${ }^{35}$ Whereas LaFarge's entrée into the interracial movement was the result of his assignment to Southern Maryland, Markoe had always been interested in working among African Americans. In 1917 Markoe and three

\footnotetext{
34 LaFarge modeled his vision of the FCC on that of Action Populaire, a French Catholic Action group that sought to implement Catholic social principles. One of the prerequisites for hierarchical approval of Catholic Action was strict clerical supervision.

35 Southern, Limits of Catholic Interracialism, 109. Southern cites Mary Nichol's interview with Claude H. Heithas, S.J. (June 5, 1973).
} 
fellow seminarians, his brother John Markoe, Austin Bork and Horace

Frommelt, pledged "to give their whole lives and all our energies as far as we are able for the work and salvation of the Negroes in the United States. "36 Markoe held that black culture was superior to that of whites and "lamented that he had no 'black blood' in his veins." 37

In 1926 Markoe was assigned to St. Elizabeth's Parish, an all black parish in St. Louis that served the city's entire black population. He published articles in the Jesuit weekly America chiding the Church on its racial policies and advocated full equality for blacks. Markoe's strident tone, however, was unsettling to his superiors and the editorial staff at America. In 1928 Markoe began publishing the St. Elizabeth's Chronicle, a weekly parish newspaper. ${ }^{38}$ He distributed the paper to black Catholic parishes across the country and in 1929 changed the name of the paper to The Chronicle in order to emphasize its national stature. Eventually, the paper became the official journal of the FCC. But as Markoe's interracial activities increased, the paper came under increasing scrutiny by the Chancery of St. Louis, which by 1930 was censoring his articles. Like LaFarge, Markoe increasingly became upset with the FCC's policy of limiting membership to blacks. Whereas LaFarge was content to work behind the scenes for a change in the FCC policy, Markoe published an article in the July 1930 edition of

\footnotetext{
36 McGreevey, Parish Boundaries, 39-41. See also Southern, Limits of Catholic Interracialism, 111.

37 Markoe quoted in Ibid, 110. St. Elizabeth's parish boundaries encompassed all of the city of St. Louis. The Church was located at $14^{\text {th }}$ and Gay Streets and was founded in 1873.

38 Southern, Limits of Catholic Interracialism, 115.
} 
The Chronicle entitled "Our Jim Crow Organization." 39 Noting that the name of the FCC was not indicative of its goals, Markoe offered the FCC a backhanded compliment, applauding the organization for attempting to forge "a closer union between all Catholics."40 Markoe then went on an extensive tour of the Midwest and Northeast and publicly rallied support for a policy change regarding FCC membership. While Markoe publicly squabbled with the FCC, LaFarge began maneuvering behind the scenes to have Turner ousted as FCC president. For his part, Turner's initial reaction was to remain cordial with the chaplains and avoid a confrontation.

In 1931 LaFarge petitioned Turner to reorganize the FCC and place control of the organization in a small board of directors, as had been the case with the Cardinal Gibbon's Institute. He threatened to resign from the FCC when black Catholic laymen challenged clerical control of the FCC chapter in Philadelphia. ${ }^{41}$ LaFarge wrote to Turner and explained that what was at stake was "the whole question of ecclesiastical authority." 42 In 1932 LaFarge suggested the FCC change its name to the National Catholic Interracial Federation (NCIF). Despite Turner's objections, LaFarge pushed the change through at the FCC's national convention in New York. ${ }^{43}$ Following the convention, LaFarge suggested that Markoe, now in New York after having been

39 Markoe, William. "Our Jim Crow Organization.” The Chronicle, July 1930, 149-150.

40 Ibid.

${ }^{41}$ Father Vincent Dever was the chaplain of the Philadelphia Chapter.

42 LaFarge quoted in ibid,127-8.

43 Southern, Limits of Catholic Interracialism, 130-131. 
removed by his superiors from St. Elizabeth's, change the name of his paper from The Chronicle to the Interracial Review. This proved to be the final straw. Turner was furious with LaFarge and Markoe. He informed the priests that the paper would no longer serve as the organization's official publication. The crisis split the FCC into two factions. LaFarge and his followers renamed their group the NCIF, while Turner and his allies attempted to continue the FCC. Animosity and continual struggles for control of funds and resources between the two factions prevented either organization from achieving any degree of success, and both disbanded within a few years. W.E.B. DuBois wrote about the debacle in the Crisis in March of 1933. Turner and his supporters, "stood up and talked like men," DuBois wrote, "instead of begging like supplicants." Parodying the clerical argument against belonging to a Jim Crow group, DuBois mimicked, “Don't segregate yourselves! Let's all go together, white and black, and let the whites lead you!"44

LaFarge next turned his energies towards the construction of a new organization. He organized the Clergy Conference on Negro Welfare (CCNW) in 1933. In targeting the clergy, LaFarge sought to spread the message of interracial justice to those who were unlikely to come into contact with African Americans or their concerns. He envisioned the Conference to be a clearinghouse of ideas and a platform for promoting the cause of interracial

44 W.E.B. Dubois, "The Negro and the Catholic Church," The Crisis 42 (March 1933), 68-9. 
justice among the clergy. In the fall of 1934, the CCNW sent out a letter to 10,000 priests in the northern United States. It stated:

Nothing will more readily create a conviction in the minds of the colored people that the Church is genuinely interested in their salvation, than to see the obstacles that they daily encounter in trying to do their duty--obstacles that their more fortunate white brethren little suspect. They are told that it is their duty to lead industrious lives and support their families. Yet of all the people in this country the Negroes have the greatest difficulty obtaining employment. They are told to bring up their children in fear of God. Yet they find that their attempts to provide decent homes or suitable education for their families meet with resentment. The Catholic Negro, in particular, is often prevented by insuperable obstacles from giving his children a Catholic education. 45

That LaFarge focused his efforts entirely on Northern diocese indicated the limited influence the Catholic interracial movement hoped to have.

While LaFarge was optimistic that priests would be receptive to his message, he was aware that there were a number of men in the Church who threatened to undermine the organization. Two key members of the diocese, Monsignor James Francis Mclntyre, the chancellor, and Father Charles McCann, pastor of St. Charles Borromeo Parish, the largest African American parish in Harlem, opposed LaFarge's plan from the outset. Mclntyre made it clear to LaFarge that he thought the Church's only concern should be for the spiritual welfare of blacks, and not their economic, social or political welfare. McCann

45 George Hunton All of Which I Saw, Part of Which I Was, 148. One of the founding members of the CCNW and a signer of the letter was Father John Ryan. Other signers included: Father Wilfred Parsons, S.J., editor of America, Father James Gillis, C.S.P., of Catholic World, Father Joseph Corrigan, rector of Overbrook Seminary, Father John Delaney, secretary to the Bishop of Newark, Father Hugh Lamb, chancellor of the Archdiocese of Philadelphia, and two professors from Catholic University; Fathers Francis Walsh O.S.B. and John Cooper. 
saw LaFarge's CCNW as a threat to his own evangelical work in Harlem. ${ }^{46}$

LaFarge reluctantly realized that the success of the Catholic interracial

movement rested in the hands of a lay run organization. He wrote:

The clergy worked out the principles and their lay associates worked out the immediate and technical applications, the laymen taking sole responsibility for the latter. This keeps us clergy and Jesuits out of the controversial special issues while it enables us to get across what is really essential. 47

A lay-run organization under his control would provide the necessary cover from the interference of McCann and Mclntyre. While LaFarge always stressed the need to operate with the approval of the hierarchy, he understood that the question of authority made the already daunting task of implementing racial justice in the Church almost impossible for a non-lay group.

LaFarge had founded the Catholic Layman's Retreat Union (CLRU) in 1928. The group consisted of twenty-five black Catholic professional men from the New York area. Membership was by invitation only. ${ }^{48}$ The union's primary mission was to provide liturgical and spiritual renewal for African American men. The program involved personal spiritual reflection and growth and communal worship. In his memoirs he wrote:

The task, as I saw it, was one of getting to work early on the problem of social reconstruction. That meant a fundamental renewal of religious life in its totality, and particularly the renewal of communal religious worship as was practiced in the earlier ages of the Church and was recommended by the leading liturgical scholars of the present time. ${ }^{49}$

\footnotetext{
46 Southern, Limits of Catholic Interracialism. 180.

47 LaFarge quoted in McDonough, Men Astutely Trained, 130.

48 Cardinal Hayes of New York formally approved of the C.L.R.U. rules on February 15, 1932.

49 LaFarge, Manner, 246. The "leading liturgical scholars of the time" refers to the founding of the magazine Orate Frates (known today as Worship) in November of 1926 by Father Virgil Michel
} 
LaFarge served as the group's chaplain and led the group's retreats. The CLRU also maintained an outreach program that was designed to educate and inform both white and black, Catholic and non-Catholic alike, on the issue of interracial justice. The group sponsored bi-monthly lectures, retreats, seminars and forums that dealt with the racial question and the Catholic position. A weekly radio show, the "Interracial Hour" on New York station WLWL, was another feature of the program. The show consisted of various speakers who discussed the issue of racial justice. Many of the CLRU members, such as Elmo Anderson, Maceo Thomas and Emanuel Romero, had been members of the FCC and left along with LaFarge in 1933. Realizing that a group as small as the Union was unsuited to playing a leading role in the Catholic interracial movement, LaFarge began planning yet another organization. The Catholic Interracial Council of New York (CICNY) grew out of the early educational endeavors of the CRLU.

The CICNY would be everything that the FCC had not been-- run by laity, under the firm control of LaFarge, integrated, and dedicated to promoting the cause of interracial justice within the Church. The mission statement adopted by the CICNY explained:

It is necessary that the Negro secure the essential opportunities of life and the full measure of social justice. All educational opportunities should be made available to Negro youth, both as a matter of right and in order to develop Catholic leaders. ${ }^{50}$

O.S.B. The aim of the periodical was to bring all Catholics together through the celebration of the mass and reverence for the mystical body of Christ. Cf: ed. John Tracy Ellis, Documents of American Catholic History Vol. II (Chicago: Henry Regnery Company, 1967).

50 Hunton, All of Which, 88. 
It declared that the problem was primarily a moral issue and was of concern to all Catholics, regardless of race. Again, the favored means of achieving racial justice was education. The statement also signaled a broader engagement with other interracialists than previous groups LaFarge had been involved with. The board was made up of Catholic laymen and women and LaFarge served as a chaplain. ${ }^{51}$ The day chosen to inaugurate the CICNY was May 20, 1934, Pentecost Sunday. LaFarge chose the date to emphasize the union of all people in the mystical body of Christ through the Holy Spirit. The proceedings were held in New York's Town Hall before an estimated crowd of 800 . The program began with an acknowledgment of sin on the part of all white Catholics for allowing racism to exist in the Church. It ended with a call to Catholics to implement the Church's teachings. ${ }^{52}$

The CICNY attempted to reach four audiences: Catholic labor organizations, colleges, social clubs (e.g. the Knights of Columbus), and African Americans. The CICNY used LaFarge's numerous personal contacts in the Church in order to reach Catholic groups. Establishing relationships with African American organizations proved to be more difficult. To promote the CICNY and the Church as a whole in the field of race relations, the Council began to carry

\footnotetext{
51 The board included Elmo Anderson, Maceo Thomas, Jim Hoey (Chief Revenue Collections Officer for New York City), Emanuel Romero, Dr. Hudson Oliver, Dorothy Day (editor of The Catholic Worker), Michael Williams (editor of Commonweal), Francis Mosely, and Nicholas Donnelly.

52 Cf: Martin A. Zeilinski, "Working for Interracial Justice: The Catholic Interracial Council of New York, 1934-1964," U.S. Catholic Historian (1990), 235-236.
} 
news items that dealt with issues affecting the African American community in the Interracial Review. The Interracial Review now served as the official paper of the CICNY. LaFarge assigned Catholic layman George Hunton to edit the journal. Hunton was a lawyer who had become interested in interracial justice while attending Fordham University Law School. Hunton and LaFarge had served together on the board of directors of the Cardinal Gibbon's Institute. ${ }^{53} \mathrm{He}$ and LaFarge wanted to change the public image blacks had of the Church. In 1934 Hunton contacted the news bureau of the National Catholic Welfare Conference (NCWC), the national administrative board of the American bishops, and pressed for wider coverage of issues concerning African Americans. Hunton discussed the issue with Frank Hall, director of the News Service for the NCWC. Hall responded, saying:

Our news service holds itself open at all times for news of Negro happenings which have a particular importance to Catholics and that we are particularly anxious to have such news ... we are not disposed to submerge Negro news because of racial feelings; and that we are glad of an opportunity to bring the problems of the Negro to the fore. ${ }^{54}$

Similar efforts were made to reach out to a group that had long been suspicious of the Church, the Black press. The CICNY hoped the Black press might cover news of Catholic activities in exchange for coverage of African American stories in the Catholic press.

\footnotetext{
53 Hunton recounted that his work under Father Terrence Shealy, a noted Jesuit sociologist, was instrumental in the development of his thought.

54 Frank A. Hall letter to George Hunton. June 13, 1934. Cited in Zielinski, "Working for Justice," 237.
} 
The CICNY did not consider itself the only organization capable of leading the interracial movement. It actively promoted the establishment of councils in other cities and sought to work with other organizations. The first major event that the council took up forced some members of the Black press to rethink their anti-Catholic bias. That event was the trial of the "Scottsboro Boys." The American Scottsboro Committee (ASC) was formed in 1934 just as the trials of two of the nine men accused of raping two white woman three years earlier were to come before the Supreme Court. The ASC's Executive Director, Dr. George Haynes, had attended the inauguration of the CICNY. ${ }^{55}$ He asked both Hunton and LaFarge to join the ASC, in the hopes of enlisting the aid of the CICNY. But the effort to provide for the defense of the accused men was ill fated. The group became entangled in a conflict with a rival group, the National Scottsboro Herndon Action Committee (NSHAC), which had communist ties. The ASC was unable to raise a defense fund, as they were unable to distance themselves from the Herndon group. Within a year the committee disbanded. Although the effort failed, it provided the CICNY with its first real experience of running a national campaign and enabled the Council to make contacts with other interracial justice organizations such as the National Association for the Advancement of Colored People (NAACP) ${ }^{56}$

\footnotetext{
55 Haynes was also the director of the Race Relations department of the Federal Council of Churches of Christ in America at the time.

56 Southern, Limits of Catholic Interracialism, 196.
} 
That same year LaFarge and the CICNY supported a key piece of antilynching legislation, the Costigan-Wagner bill. The Council published a number of articles and editorials expressing support for the bill. ${ }^{57}$ In December the CICNY cosponsored a rally with the NAACP in support of the legislation. ${ }^{58}$ Although the Costigan-Wagner bill was defeated, the CICNY continued to support anti-lynching legislation. Three years later, the CICNY sent telegrams to various senators urging support for the new Wagner-Van Nuys-Gavagan bill. Despite its efforts, the bill died at the hands of a twenty-two day Southern filibuster. 59

More successful than its lobbying efforts was the council's educational program at Catholic colleges and universities. The CICNY's first presentation on interracial justice to a Catholic college took place at Manhattanville College of the Sacred Heart in New York City in April and May of 1933. The President of the College, Mother Grace Dammann, R.S.C.J. invited George Hunton to give a series of talks to the all-female, all-white student body on the race question and the Catholic Church. At the end of the lectures, the student body met privately and asked Mr. Hunton to return and help them implement what he had

57 Cf: Interracial Review: Paul Blakely, "The Right Not to be Lynched," (December 7, 1934), 134, "Open Letter to Father Charles Coughlin," (March 8, 1934), 34, "Anti-Lynching Bill," (September 9, 1935), 132, "Catholics and the Anti-Lynching Bill," (September 9, 1935), 131-132. See also: Amy MacKenzie "Walter White on Lynching," (September 9, 1935), 135, and "A Fourteen Point Indictment of Lynching," (April 10, 1937), 51-52.

58 Cf: Zielinski, "Working for Justice," 239.

59 Martin A. Zielinski "Doing the Truth: The Catholic Interracial Council of New York, 1945-1965." (Unpublished Ph.D. Dissertation: Catholic University of America, 1989), 35-36. 
discussed. The outcome was the "Manhattanville Resolutions." The students declared:

Whereas I am enjoying the privileges of a Catholic higher education, I recognize that I have certain duties and obligations towards my fellow man, among which I must consider my conduct and attitude toward the American Negro. 60

The resolutions went on to acknowledge the complicity of all persons in the sin of racism and reaffirmed that "the Negro shares my membership in the Mystical Body of Christ."61 The Brooklyn Catholic Interracial Council, in a pamphlet entitled "All Men are Equal," published the resolutions. It was the first pamphlet on Interracial Justice published under Catholic auspices in the United States. 62 Numerous colleges and universities throughout the United States such as Notre Dame, Boston College, Holy Cross and Marymount adopted these resolutions. In 1937 the newly formed National Federation of Catholic Alumni adopted the resolutions and formed an Interracial Committee.63 Four years later the CICNY adopted a "Standard Program for Adoption in Catholic Colleges."

The method the CICNY used to promote their case can best be described as an "Interracial Hearing." Hunton based the technique on the practice of moot courts, with which he would have been familiar as a lawyer. The process was to present, in a court like setting, representatives of the Catholic Church and the

\footnotetext{
60 The resolutions were published in a Catholic Interracial Council Pamphlet. Francis Mosely Brooklyn, "All Men Are Equal: A Brief for the Black Man," (1934), 3. John LaFarge Papers (JLP) Box 5 .

61 Mosely, "All Men Are Equal," 3.

62 Hunton, All of Which I Saw, 94.

63 Southern, Limits of Catholic Interracialism, 206.
} 
African American Catholic community and to cross-examine them as if they were on trial. The audience was given the role of jury, and it was their task to decide whether or not the Church was living up to her responsibilities. Scripture and Papal Encyclicals such as Rerum Novarum (1891), Quadragessima Anno (1931) and later Divini Redemptoris (1937) and Sertum Laetitiae (1939) were discussed in light of the Church's teachings on race.64 The first attempt at an "Interracial Hearing" was made at Providence College in Rhode Island on March 20, 1938. LaFarge represented the Church, Elmo Anderson represented the black Catholic point of view, and Hunton played the role of mediator/attorney. ${ }^{65}$ The aim of the program was to educate the students and get them interested in working for interracial justice at their schools and in their communities. At the end of each session the presenters would place before the audience for adoption a set of resolutions based upon the "Manhattanville Resolutions."

In 1938 LaFarge traveled to Rome where he was asked by Pope Pius XI to write an encyclical addressing racism. The pope was familiar with LaFarge's

\footnotetext{
64 Rerum Novarum May 15, 1891, On Capital and Labor, Quadragesimo Anno, May 15, 1931, On the Reconstruction of the Social Order, Divini Redemptoris, March 19, 1937, On Atheistic communism, and Sertum Laetitiae, November 1, 1939, On the Establishment of the Hierarchy in the United States.

65 Cf: Transcript of Interracial hearing at Providence College (March 20, 1938), 4-5. JLP Box 30 File 1. Schools who participated in the program were: College of Mt. St. Vincent's (New York City), College of New Rochelle (New Rochelle, New York), College of St. Elizabeth (Convent Station, New Jersey), College of the Sacred Heart (New York City), Manhattan College (New York City), Fordham University (Bronx, New York), St. Francis College (Brooklyn, New York), St. John's University (Brooklyn, New York), St. Joseph's College for Women (Brooklyn, New York), St. Joseph's College (Philadelphia, Pennsylvania), St. Joseph's College (Hartford, Connecticut), and St. Peter's College (Jersey City, New Jersey).
} 
work and instructed him to write the letter as if he were the pope.66 The assignment was perhaps the highpoint of the Jesuit's career. LaFarge, along with two other Jesuits, worked in secret for months only to have their work undermined by Father Wlodomir Ledochowski, Superior General of the Order. LaFarge gave the completed document, entitled "The Unity of Mankind," to Ledochowski and not the Pope. LaFarge covered much the same ground that he had covered in his previous work. He condemned distinctions based on race, but fell short of declaring all segregation immoral. LaFarge asserted that "such differences and social aspirations as brotherly love and prudence may counsel to the advantages of all different races in view of their actual circumstances" would not be considered discriminatory. Ledochowski was opposed to the encyclical since he felt that Communism posed a much greater threat to the Church than the German racialism. He held on to the completed document for months. When Pius XI died, his successor opted not to issue the letter. ${ }^{67}$ Ironically, the opportunity LaFarge had been given to speak for Rome on the racial problem in America was lost just as the racial issue, which had been viewed by Catholics as a Southern problem, began to press North.

European Catholic immigrants had created an insular world in Northern cites with Catholic social and professional institutions that mirrored their

66 Southern, The Limits of Catholic Interracialism, 231.

67 LaFarge quoted in Southern, Limits of Catholic Interracialism, 232-237. McDonough, Men Astutely Trained, 56-68. 
Protestant and secular counterparts. ${ }^{68}$ Churches dominated the clearly defined geographical parishes. They included schools, convents, rectories and, in many cases, gymnasiums and auditoriums. ${ }^{69}$ Prior to the 1920 s, the North had a relatively small African American community, but in the 1930s as a result of deteriorating economic conditions in the South, large numbers of Southern blacks migrated from the Black Belt to new opportunities in the industrial North and Midwest. For the first time, northern Catholic dioceses were confronted with racial problems as substantial numbers of African Americans moved into Catholic neighborhoods. Many bishops, clergy and laity viewed the influx of Southern blacks as at best a drain upon their limited resources and at worst a threat to the stability of Catholic parishes. Because each parish had distinct geographic boundaries, Church officials encouraged home ownership. Catholic parishes were remarkably stable communities. For European ethnic Catholics, leaving the area meant abandoning the parish. As African Americans, most of whom were Protestant, moved into Catholic enclaves, parishioners often responded to the integration of their neighborhoods with violence. They struggled over housing and not specifically race. ${ }^{70}$

Ethnic groups that had previously competed against one another banded together to halt the influx of blacks. European Catholics, John McGreevey notes, "could lay claim to shared European heritage" and ethnic identity was flattened

68 Charles Morris, American Catholic: The Saints and Sinners Who Built American's Most Powerful Church, (New York, Random House, 1990), 160.

69 McGreevey, Parish Boundaries, 15. 
into a racial one. ${ }^{71}$ Parish priests often led opposition to the integration of neighborhoods, and violence flared in New York, Chicago, Philadelphia and Boston as Catholics tried to prevent integration. ${ }^{72}$ Integrated housing would be the primary issue that Catholic Interracial Councils addressed around the country during the war and the decade that followed. Local Catholic Interracial Councils tried to counter anti-black sentiment, pressed bishops to condemn such actions and attempted to mediate local situations. ${ }^{73}$ The CICs also pressured the city, state and federal governments to build integrated housing projects, and applauded the 1948 Supreme Court ruling, which ruled against restrictive housing covenants. ${ }^{74}$ The failure of the Catholic Interracialists to prevent antiblack violence on the part of the fellow Catholics highlights to the obstacles they faced and the limits of a purely educational program.

Most African Americans moved North in search of jobs, and LaFarge used the threat of communism and especially its potential appeal to African American workers as leverage against the hierarchy's intransigence on racial issues. While the advent of the cold war heralded America's engagement with the 'red menace,' Catholics had been struggling against communism since the Russian Revolution. The appearance of the Virgin Mary to three young shepherds at

70 Ibid, 20.

$71 \mathrm{lbid}, 34,36$.

72 Cf: McGreevey, Parish Boundaries, 91-101.

73 Southern, Limits of Catholic Interracialism, 252-253.

74 Shelly v. Kraemer 334 US 1 (1948) and Hurd v. Hodge 334 US 26 (1948). 
Fatima, Portugal in 1917 framed the battle with Communism in apocalyptic terms. The Marian vision, the first of the twentieth century, told the young girl: I come to ask the consecration of Russia to my Immaculate Heart If [the world's Catholics] listen to my request, Russia will be converted and there will be peace. If not she will scatter her error through the world, provoking wars and persecution of the Church. ${ }^{75}$

Catholics therefore viewed the confrontation with Communism as much more than a battle between competing political ideologies.

The pace of civil rights protest picked up with the outbreak of World War II as African Americans fought for the "Double V," victory against fascism abroad and racism at home. The more militant mood among African Americans affected LaFarge, and he began to reassess both the depth of the race problem and strategies for confronting it. In 1941 A. Philip Randolph, founder of the United Brotherhood of Sleeping Car Porters, the first African American labor union, threatened to organize a "March on Washington for Jobs and Freedom." The goal of the March was to force President Franklin D. Roosevelt to end segregation in all government agencies and the District of Columbia. Through his contacts in both the labor movement and the interracial movement LaFarge had maintained a close relationship with Randolph. The two had worked closely together on many projects, and Randolph often contributed articles to the Interracial Review. Randolph asked LaFarge to speak at the rally in New York's Madison Square Garden in support of the March. According to Hunton,

75 Cf: William T. Walsh, Our Lady of Fatima, (New York: McMillan Press, 1947), 83. Quoted in Morris, American Catholics, 229. 
LaFarge's impeccable anti-communist credentials made him the only white Randolph could trust. Surprisingly LaFarge cast aside his long-held belief that agitation was counterproductive and agreed to speak. Concerned that a massive march on the capitol would distract from the war effort, President Roosevelt issued executive order \#8802 in 1942 prohibiting segregation in defense industries. ${ }^{76}$

Although LaFarge concerned himself almost exclusively with the race problem in the North, he applauded the efforts of the Catholic Committee of the South (CCS), a small organization that convened ten times between 1940-1953. He lauded them for their "bold and prudent" stand against segregation. ${ }^{77}$ LaFarge was grateful for the mere fact that desegregation was being discussed at all. He declared, "This marks a definite break with the time-honored position of hush-hush."78 LaFarge continued to hold out a naïve hope that "silent Southern moderate" would eventually play an important role in ending Southern segregation. But the group never had the full support of Southern bishops and failed to generate any grassroots support among lay Catholics. Bishop Thomas Toolen of Mobile withdrew his support of CCS in 1942 noting, "All I can see is a convention once a year with a number of names that mean nothing to us in the

76 Southern, Limits of Catholic Interracialism, 248.

77 John LaFarge, "Southern Catholics and Applied Democracy," America 84 (February 10, 1951), 549-552.

78 LaFarge Letter to William Crandell, S.J., cited in Southern, Limits of Catholic Interracialism, 314. 
South, a few reproductions of pamphlets and a few meetings to attend."79

Support from the hierarchy finally came in 1943 when the American bishops issued a joint statement on the rights of black Americans. "The Essentials of a Good Peace" linked the fight for democracy and justice abroad with the racial struggle being waged at home. The bishops, in a section entitled "Constitutional Rights of the Black Man," stated:

We owe to these fellow citizens, who have contributed so largely to the development of our country, and for whose welfare history imposes on us a special obligation of justice, to see that they have in fact the rights, which are given them in our Constitution. This means not only political equality, but also fair economic and educational opportunities, a just share in public welfare projects, good housing without exploitation, and a full chance for the social advancement of their race. ${ }^{80}$

The bishops of the administrative committee of the NCWC were on record in support of the Catholic interracial movement. ${ }^{81}$

The Catholic Interracial movement also pressured Catholic labor leaders and union organizers to integrate. While the Catholic labor movement had as its philosophical underpinnings the major papal statements on labor and the rights of the workingman, labor leaders had more often than not refused to cooperate with their interracial counterparts. Despite pressure from Catholic labor leaders,

\footnotetext{
79 Letter cited in Katherine Martensen, "Region, Religion and Social Action: The Catholic Committee of the South, 1939-1956," Catholic Historical Review 69:2 (1982), 249-265. 254.

80 "Essentials of a Good Peace." In Documents of American Catholic History ed. Ellis, John Tracy (Wilmington: Glazier Press, 1987).

81 Hugh Nolan, Pastoral Letters of the American Hierarchy, 1792-1970, (Huntington, IN: Our Sunday Visitor, 1971), 388. The NCWC Administrative committee included; Archbishop of Detroit Edward Mooney, Archbishop of Chicago Samuel Stritch, Archbishop of New York Francis Spellman, Archbishop of Cincinnati John Nicholas, Archbishop of San Francisco John Mitty, Bishop of Fort Wayne John Noll, Bishop of Erie John Mark Gannon, Bishop of Toledo Karl Alter, and Bishop of Buffalo John Duffy.
} 
such as Monsignor John Ryan, founder of the Social Action department of the NCWC and the leading American theoretician of Catholic social justice, and labor mediator Father Francis Haas, the unions were ineffective in promoting racial justice within their ranks. ${ }^{82}$ The Knights of Columbus although they did not specifically restrict membership to whites, refused to investigate allegations of racism among member organizations. After years of CICNY pressure, the first African American became a member of the Brooklyn Knights of Columbus in 1950. However, the practice did not spread. In 1954 the national organization of the Knights refused Auxiliary Bishop of Cleveland Floyd Begin's appeal for the establishment of an interracial committee.

The CICNY also negotiated with Catholic hospitals and social organizations to integrate, but the group's primary focus was the integration of Catholic high schools, colleges and universities. The most important case involved the integration of St. Louis University in 1945. On February 11, 1944 Father George Heithaus, S.J., a professor of archeology, condemned racial segregation at a student Mass. He preached on the mystical body of Christ and asked that the student body pledge itself to end racism. ${ }^{83}$ Father George Dunne, S.J., who had come to teach at the school's Institute for Social Order, arrived

\footnotetext{
82 Franics Haas was a key Cathollic labor activist. The NCWC successfully pressured Washington to establish the Fair Employment Practices Commission (FEPC) to oversee implementation of the order. Father Francis Haas was named chairman of the FEPC in 1943.82 However, the FEPC was not a permanent committee, and George Hunton continued to lobby Congress for a change in its status and in support of FEP legislation. Haas was later named Bishop of Green Bay. 83 Southern, Limits of Catholic Interracialism, 261.
} 
after the decision to integrate had been made, but used the incident as a springboard to publish a number of articles in Commonweal attacking critics of integration. Calling a Christian defense of segregation as untenable as that of "Christian cannibalism," he boldly called racism a sin and a heresy. "We can go to hell for sins against charity," he wrote, "as easily for sins against justice, perhaps more easily."84 Dunne denounced anyone who cooperated with Jim Crow. He and fellow Jesuit Markoe protested the failure of the University to admit qualified black applicants. The administration bowed to the pressure and admitted five African Americans that summer. The agitation resulted in the transfer of both Heithaus and Dunne from the University. The University remained integrated, and there was no public outcry following the decision. But neither did an interracial movement blossom in St. Louis which historian Peter McDonough attributes to the particular nature of the city as a border town, neither Southern nor Northern, and the fact that the integration policy did not extend to social gatherings. ${ }^{85}$ LaFarge supported Heithaus, Dunne and Markoe, but took pains to distance himself from their statements. He added a disclaimer to a reprint of Dunne's article in America, which stated that Dunne's article did not apply to legal segregation as practiced in the South—a stance Markoe loudly denounced. 86

84 George Dunne, "The Sin of Segregation," Commonweal 42 (September 21, 1945), 545.

85 McDonough, Men Astutely Trained, 183-4.

86 Southern, Limits of Catholic Interracialism, 265. 
Integration at the secondary level proved to be a difficult task as well. Archbishop John Ritter of St. Louis integrated parochial schools in 1946. Members of the diocese refused to abide by the order, and a laymen-led legal challenge to the desegregation order was ended only after the instigators were threatened with excommunication. The following year, Archbishop Patrick O'Boyle of Washington D.C. desegregated his school system. ${ }^{87}$ Bishop Vincent Waters of Raleigh desegregated his parishes in 1954. Bishop William Adrian of Nashville, Bishop Peter Ireton of Richmond and Bishop Albert Fletcher of Little Rock ordered an end to segregation in their parochial schools. 88 These actions anticipated the Supreme Court decision, Brown v. Board of Education of Topeka, Kansas, desegregating public secondary education, and were widely hailed in the Catholic press as indications of the Church's forthright stand on the race issue. However, the actual implementation of the orders was problematic. Catholic lay opposition to parochial desegregation for the most part mirrored Southern opposition to the court's desegregation order.

The most flagrant case of lay opposition was in New Orleans. Archbishop Joseph Rummell announced an end to segregation in parishes in 1954, but did not order the integration of schools. Rummell's modest effort resulted in widespread lay opposition. In a public letter Emile Wagner, Jr., a Catholic layman and member of the New Orleans School Board, questioned why the long-

87 Davis, Black Catholics, 256.

88 Gerald Fogarty, Commonwealth Catholicism: A History of the Catholic Church in Virginia, University of Notre Dame Press: Notre Dame, 2001), 529-532. 
standing practice of segregation had suddenly become a $\sin .89$ The confrontation gained national and international attention. Not only did lay Catholics challenge Rummell on the issue of school desegregation, but Catholic laymen also challenged the bishop's right to assign priests to parishes.

In 1954 the white members of the Jesuit Bend Mission in Plaquemine parish, led by Catholic segregationist leader Leander Perez, refused to allow Father Gerald Lewis, a black priest, to celebrate mass. ${ }^{90}$ This incident was a direct challenge not only to the Church's position that all men were equal before God but openly disregarded the sanctity of the priesthood and the right of the Bishop to run his diocese. Rummell placed the Mission under interdict, suspending masses for four years. In 1955 he issued a pastoral denouncing segregation as "morally wrong and sinful." 91 When Perez instructed Catholics to withhold donations to the Church, Rummell excommunicated him.

In 1957 Rummell ordered the desegregation of the schools, but he was forced to slow down the pace. Southern Catholic laywoman Agnes Waldron counseled Catholic interracial activists against the naïve hope many held that Catholic Southerners would simply accept the orders of their bishops in regard to

\footnotetext{
89 Emile Wagner Letter to Joseph Rummel, December 14, 1955. Unpublished. Catholic University of America Archives (CUAA). National Catholic Welfare Confernce Papers (NCWCP). File 89 Box 13.

90 Southern, Limits of Catholic Interracialism, 314. See also Michael Freidland, Lift Up Your Voice Like a Trumpet: White Clergy and the Civil Rights and Antiwar Movements, 1954-1973, (Chapel Hill, University of North Carolina Press, 1998), 41.

${ }^{91}$ Rummell's pastoral quoted in Southern, Limits of Catholic Interracialism, 315.
} 
integration. Describing the "flat opposition" Rummell was facing in New

Orleans, she wrote:

He had everything in his favor- a strongly Catholic population; the liberal French influence, and the American tradition of obedience without hesitation to an archbishop speaking on a moral problem. Yet he was flatly repulsed and forced to back down. The same treatment was given to Bishop Waters in North Carolina. On that basis, it is only fair to conclude that resistance to racial equality is very deep[ly] rooted, and that attempts to change the situation are not likely to succeed, at least not this time. ${ }^{92}$

Massive resistance had a Catholic face, and full desegregation of Catholic institutions did not take place in New Orleans until 1962.93 By this time even LaFarge was growing impatient with the pace of reform in the South and the increasingly violent opposition to change. In October LaFarge asked Bishop Thomas McDonough of Savannah to push the hierarchy to speak out against racism. He declared the Church "could no longer avoid going on record" and pointed out that black Catholics were losing faith in the Church. "The strains of

92 John T. Donovan, "Crusader in the Cold War: A Biography of John T. Cronin, S.S. (19081994)," (Ph.D. Dissertation: Marquette University, 2000), 132. Southern, Limits of Catholic Interracialism, 131. 
loyalty which an older generation might endure," he noted, "can be too much for younger ones."94

93 Ibid, 316.

94 John LaFarge Letter to Thomas McDonough. October 17, 1957. GUA JLP Box 28 Folder 1. 


\section{Chapter 2 : "Pat ience."}

"Catholics believe in patience."

Bayard Rustin

Prior to 1958 the Catholic interracial movement consisted of a number of loosely affiliated interracial councils, staffed by volunteer priests and laymen, and concerned almost exclusively with the Catholic Church's response to racism. That year the movement was reorganized, revitalized and refocused. A new cadre of clerical and lay leaders, many with graduate degrees and professional experience in community organizing, stepped up to take the place of LaFarge and Hunton. These men and women pressed for the creation of a national organization to effectively promote the movement's goals and sought to broaden the movement's engagement with the emerging civil rights movements.

That year 400 delegates from 36 Catholic Interracial Councils met in Chicago for the first national $\mathrm{CIC}$ convention. Almost every city with a large Catholic, if not a substantial African American, population had a council: Boston, Philadelphia, Chicago, Washington, Baltimore, Philadelphia, Rochester, Detroit, San Francisco, Newark, Brooklyn, and Kansas City. But the 36 Catholic Interracial Councils were well below the 100 LaFarge had hoped would be established. ${ }^{1}$ The movement remained predominately a Northern one, with few inroads having been made into the South. Most CICs suffered from meager

\footnotetext{
${ }^{1}$ Southern, Limits of Catholic Interracialism, 213.
} 
funding, none had full-time staff, and all chafed under suspicious diocesan supervision. ${ }^{2}$

The goal of the conference was "to fully implement the principles of Christian Social Justice and American Democracy in regard to race relations."3 Resolutions were adopted calling upon Catholics, individually and collectively, to institute the principles of interracial and social justice, pressure the federal government to quicken the pace of desegregation, and support the work being done by the Rev. Martin Luther King, Jr., following his rise to national prominence after the success of the Montgomery Bus Boycott. The most important accomplishment of the conference was the adoption of a proposal that had been made a year earlier by Monsignor Daniel Cantwell, Chaplain of the Chicago CIC. He suggested the establishment of a federation of CICs that could more effectively promote interracial justice at the national level. The delegates appointed a committee to form the National Catholic Conference for Interracial Justice (NCClJ).

The NCClJ would serve as a national clearinghouse for information among the $\mathrm{CIC}$, direct public relations on a national level for the movement, enlarge the scope and focus of $\mathrm{CIC}$ activities, and foster new leadership. It provided services and information for affiliate members who remained independent, allowing local councils to focus on local concerns. LaFarge had rejected the idea of a national organization previously and wanted to limit the organization's role to developing

2 Ibid, 345. 
already existing councils. A national organization threatened to take up much of the responsibility and prestige that his New York council had previously enjoyed. He also worried that a wider engagement with national organizations and groups might leave the movement open to more "uncontrollable" elements. ${ }^{4}$ But the aging LaFarge's influence on the movement was waning.

Cantwell strongly believed that the younger and more dynamic Chicago Council had already effectively assumed the mantle of leadership for the interracial movement. ${ }^{5}$ Matt Ahmann, who had briefly worked with the Chicago CIC, was appointed Executive Director of the NCCIJ. He recalled that he and others in the movement believed:

We had to move as rapidly as possible so that we could move this interest in race relations in the Catholic community to the center of the apparatus of the diocese where it would have the resources and the commitment of leadership and not leave it languishing with the CICs. ${ }^{6}$

Ahmann decided to locate the NCCIJ in Chicago. Chicago was chosen as the site for the $\mathrm{NCClJ}$ because of its central location and the liberal political leanings of Archbishop Albert Meyer. The Catholic activists in Chicago enjoyed a greater degree of freedom from the diocesan authorities than their New York counterparts. In addition to enjoying episcopal support, the Chicago $\mathrm{CIC}$ was financially stable and employed a full-time staff. Consequently, Chicago had a

\footnotetext{
${ }^{3}$ McGreevey, Parish Boundaries, 86.

4 Southern, Limits of Catholic Interracialism, 330.

$5 \mathrm{lbid}$. It is interesting to note that both John LaFarge's and George Hunton's autobiographies neglect to discuss the issue of the loss of the CICNY's status as leader of the Catholic interracial movement even though both men end their stories in 1960 two years after the $\mathrm{NCClJ}$ is formed.

${ }^{6}$ Matt Ahmann Interview by author (20 December 1993).
} 
more dynamic history of interracial activity in the area of housing integration and community organizing. ${ }^{7}$ However, Archbishop Meyer was ill, and Ahmann and LaFarge both feared that his successor might not be as supportive of the new organization. In order to provide better political cover for the NCCIJ, LaFarge and Ahmann arranged to have the organization listed under O'Boyle's jurisdiction in Washington in the Catholic Directory while allowing it to remain headquartered in Chicago. ${ }^{8}$

There were three major reasons for the change of direction within the Catholic interracial movement: the increasing importance and seriousness of the race issue and the need to formulate an effective response, the growing importance of the lay apostolate, and the professionalization of the CIC. ${ }^{9}$ As younger Catholic interracialists sought to take a more active stance on the racial issue in both the Church and the nation, the CICs were forced to confront the growing militancy and demands of blacks. For the new cadre of leaders, the educational programs LaFarge had developed seemed out of step with the times. CICs began to reassess their programs and embrace new strategies and tactics for achieving racial justice. The renewed emphasis on the integral role of laymen and women was in marked contrast to LaFarge's view of a docile laity. The involvement of men and women who had received professional degrees, often

\footnotetext{
7 Ahmann Interview and John McDermott Interview by author. (20 January 1994).

$8 \mathrm{lbid}$. Ahmann recounts that "[LaFarge and I] went off to see O'Boyle and O'Boyle answered LaFarge's question without it ever being asked-- it was a masterful piece of diplomacy. I was amazed when I left there. O'Boyle said list it under me and keep it in Chicago."
} 
from Catholic colleges and universities, highlighted the important new role laity were beginning to play in the movement. The CICs were transformed from voluntary groups into professionally staffed social organizations. All of these factors contributed to a broadening of the scope of CIC activity. The Councils began to engage with the entire community.

Further support for the Catholic interracial movement came in November 1958 when the American bishops issued "Discrimination and the Christian Conscience." The pastoral, like the Chicago Conference, signaled a change in the leadership and direction of the interracial movement. LaFarge was now out of the ecclesiastical loop. His age and his style caught up with him as a new generation of Catholic laymen and clergy took their places at the forefront of the struggle. The pastoral was written not by LaFarge, but by Father John Cronin, S.S., assistant director of the National Catholic Welfare Conference's Social Action Department. A staunch anti-communist, Cronin was used by the FBI as a source to leak information on suspected communists to the House Un-American Activities Committee. ${ }^{10}$ Like LaFarge, he used the communist threat and its potential appeal to African Americans to press the hierarchy for racial reform. ${ }^{11}$ Cronin had been traveling in Europe during the 1956 Little Rock school desegregation crisis and was shocked and humiliated by the events. When he

9 John McDermott, "CIC's Changing Role," (1964) Chicago Historical Society (CHS) Chicago Catholic Interracial Council Papers (CCICP) Box 109 File "McDermott."

10 Cronin was a confident of Senator Richard Nixon, who sat on House Un-American Activities Committee.

${ }^{11}$ McGreevey, Parish Boundaries, 67. 
returned he began lobbying the NCWC administrative board to issue a statement on racism. ${ }^{12}$ Cronin anticipated many of the possible objections but declared, "Even if . . . we lost some Catholics in the South, I still think that we would be far ahead arithmetically in a few years, to say nothing of the worldwide impact of our moral leadership."13 NCWC board member Edward Cardinal Mooney of Detroit, however, was against bringing up such a divisive issue among the hierarchy. Archbishop O'Boyle agreed with Cronin and personally pressed his fellow bishops to act. Pointing out that Protestants had already spoken out on segregation, O'Boyle convinced Mooney that a pastoral on racism "was necessary for the moral guidance of our people" and noted, "the American public will feel that silence on our part would mean acquiescence."14

However, the bishops' statement masked deep divisions among the hierarchy. A month before the pastoral was issued, Bishop John Russell of Richmond wrote to O'Boyle in order to set forth the concerns Southern bishops had with the draft statement. He explained that the Southern bishops were concerned about white flight from the Church and did not want to risk the immediate benefits of integration against the potential loss of "two million souls." 15 Rummell also noted that the practice of segregation had been upheld by the decisions of the federal, district, and state courts for decades, as well as

\footnotetext{
12 Donovan, Crusader in the Cold War, 317.

$13 \mathrm{lbid}, 140$.

14 O'Boyle letter cited in Donovan, "Crusader in the Cold War," 140-141. Southern, Limits of Catholic Interracialism, 317.

15 Joseph Russell Letter to Patrick O'Boyle. October 25, 1958, 2. CUAA NCWCP, Box 89 File 13.
} 
"by the practices of the Catholic Church herself providing separate schools for the Negroes with the permission of the Holy See."16 Many bishops felt that the Church ought not to be involved in questions regarding the social and political status of blacks at all. He quoted one unnamed bishop as saying:

The principle and primary mission of the Church, as of Christ, is to save souls, and not to better the material lot of minorities. The latter the Church should promote, as it is in her competence and mission, but only in a secondary way and not to the detriment of the principle objective, the spiritual welfare of her people, salus populi suprema lex. ${ }^{17}$

Russell listed nine Southern dioceses that as of 1958 had not integrated: Atlanta, Savannah, Miami, St. Augustine, Alexandria, Mobile-Birmingham, NatchezJackson, Charleston and Lafayette. He also pointed out the difficulties Rummell was having in New Orleans. ${ }^{18}$ As a compromise, Russell requested a number of changes to the final draft. He dismissed the statement "We have moved with firm determination to bring together all our peoples, regardless of race, in our Churches, schools, and hospitals" as patently untrue, and he requested that the phrase "fight for this principle" be changed to "work for this principle."19 Some bishops refused to sign the pastoral, while others were reluctant to publish it. Fearing the pastoral would not be issued, Monsignor Paul Tanner of the NCWC leaked a copy to the Apostolic Delegate, Archbishop Amelio Cicognani.

\footnotetext{
$16 \mathrm{lbid}, 1$.

17 Ibid, 1. "The welfare of the people shall be the supreme law."

$18 \mathrm{lbid}, 2$.

$19 \mathrm{lbid}, 2$.
} 
Cicognani passed it along to Pius XII in Rome. The Pope, who lay on his deathbed, ordered the bishops to issue the statement immediately. ${ }^{20}$

Affirming the message that LaFarge and other Catholic interracialists had been proclaiming since the mid-1930s, the bishops declared, "The heart of the race question is moral and religious." They clearly stated that segregation could not be reconciled with the teachings of the Church. However, just as the Supreme Court had done in the Brown decisions, the bishops offered no timetable for remedying the issue. ${ }^{21}$ Instead, they counseled against both "a gradualism that is merely a cloak for inaction" and "rash impetuosity that would sacrifice the achievements of decades in ill-timed and ill-considered ventures." The decision on the implementation of integration, the bishops wrote, should be left up to "the prayerful and considered judgment of experienced counselors who have achieved success in meeting similar problems."22 Four years later, when the Second Vatican Council opened in Rome, few bishops even mentioned race as a topic when asked to suggest topics for discussion. ${ }^{23}$ While the idea of racial justice was gaining wider acceptance among mainstream Catholics, it remained far from a pressing issue.

On February 1, 1960, the sit-in movement began in Greensboro, North Carolina. The student-led movement used the principles of nonviolence and civil

20 Donovan, "Crusader in the Cold War," 90-1, 141.

21 On May 31,1955, the court had ordered that desegregation be pursued with "all deliberate speed."

22 "Discrimination and the Christian Conscience," In Documents of American Catholic History ed. Ellis, John Tracy (Wilmington: Glazier Press, 1987), 642-647. 
disobedience as a provocative tactic to force the issue of desegregation throughout the South. The Interracial Review printed several editorials, which supported the demonstrators. A July editorial, commented:

We are in favor, as we have always been, of negotiation, of arbitration and discussion. We prefer the council table to the picket line. But millions of our fellow citizens are convinced that direct action only will succeed. We have to admit that this is not time to indulge in exhortation. In this crisis, the simplest solution is the one that has always been the best and the only one: give the Negro his rights. ${ }^{24}$

But the editorial stopped short of an outright endorsement of the new protest tactics, highlighting LaFarge's conservatism. Matt Ahmann bristled at the outdated responses of the Catholic interracial movements noting, "there have been very few imaginative attempts on the part of Catholic people or institutions to face the problem and to work to solve them." 25 Father William Kenealy, S.J., a professor of Law at Loyola University in Chicago defended the rights of individuals to protest nonviolently and cited Church doctrine and teachings. ${ }^{26}$ Both the NCCIJ and the Chicago CIC honored the North Carolina A\&M students for their actions. ${ }^{27}$

A year later, two integrated teams of demonstrators from the Congress of Racial Equality (CORE) planned to test a Supreme Court ruling which banned discrimination in interstate travel. After three days of training, the integrated

23 McGreevey, Parish Boundaries, 136.

24 "Editorial," Interracial Review (July, 1961), 185.

25 McGreevey, Parish Boundaries, 140.

26 William Kenealy, "The Legality of the Sit-ins," in Matthew Ahmann (ed.), The New Negro (New York: Bilbo and Tannen, 1961), 63-88.

$27 \mathrm{Ibid}$. McGreevey notes that one of the four men was Catholic but does identify him. 
group of CORE volunteers boarded two Greyhound buses in Washington, D.C. and set off for New Orleans. ${ }^{28}$ The Freedom Rides left on May 4, 1961 and were scheduled to arrive in New Orleans on May 17, the seventh anniversary of the Brown decision. ${ }^{29}$ The demonstrators traveled to Rock Hill, South Carolina without incident. ${ }^{30}$ However when the groups reached Alabama on May 14 violence erupted. The first group was attacked by a large mob in Anniston, Alabama. The mob stoned the bus, slashed its tires and pursued it as it fled the city. When the vehicle came to a halt six miles outside of town, the mob firebombed it, and barricaded the door. Only the intervention of the director of the Alabama Highway Patrol prevented a massacre. The Klu Klux Klan attacked the second group in Birmingham, Alabama. The Klan had reached an agreement with the local police chief. The police told the Klansmen that they would have fifteen minutes to deal with the demonstrators before police arrived on the scene. ${ }^{31}$ CORE leaders considered canceling the demonstration. When the group arrived in Montgomery, they were once again beaten by an angry mob as police stood by.

\footnotetext{
28 John Lewis with Michael D'Ors, Walking with the Wind: A Memoir of the Movement, (New York, Simon \& Shuster, 1998), 135. Another group had attempted a similar action fifteen years earlier. Billed as the "Journey of Reconciliation," integrated groups had ridden buses through Virginia, Kentucky and Tennessee. However, the demonstration was largely symbolic and never generated a great deal of publicity or support.

$29 \mathrm{lbid}, 135-174$.

$30 \mathrm{lbid}, 142$.

31 Dianne McWhorter, Carry Me Home: Birmingham, Alabama, Climactic Battle of the Civil Rights Revolution, (New York, Simon \& Schuster, 2001), 194. See Also Lewis. Walking with the Wind. 145-146.
} 
Catholic reaction to the Freedom Rides of 1961 was mixed and

highlighted the divisions among Catholic interracialists. Father Robert Wilken of

North Carolina praised the actions of the demonstrators, declaring:

Those who preach prudence for others are often the standpatters who never take a step involving self-sacrifice, even embarrassment, on behalf of social or economic justice. Piously and pusillanimously they caution prudence: "Education will do it!" "Let's not push things!" "As long as they keep their place, I'm all for the $\mathrm{N}$-----rs getting ahead." All the shibboleths of gradualism, so long as they enforce and canonize passivity, we utter pompously and inanely. Christ said boldly: "Blessed are they that suffer persecution for justice's sake, for theirs is the Kingdom of Heaven." To the Freedom Riders we say the same. ${ }^{32}$

The Detroit CIC called for a student from every Catholic college and university to participate in the Freedom Rides. Other organizations were supportive, if less in favor, of increased involvement. ${ }^{33}$ In contrast, Father Patrick Molloy of the St. Louis CIC declared that the Freedom Rides were designed to incite violence and suggested a possible communist involvement in the affair. The NCCIJ and CICNY both issued strong statements denouncing Molloy's analysis. ${ }^{34}$ A number of the Freedom Riders were Catholic laymen and women. Diane Nash of the Student Nonviolent Coordinating Committee (SNCC), Phil Havey of the New York Catholic Worker, Bill Hansen of Xavier University, Cincinnati, Terry Sullivan

\footnotetext{
32 Robert Wilken, "Gadfly Freedom Riders," Interracial Review (October, 1961), 247.

33 McGreevey, Parish Boundaries, 143-145.

34 Zielinski, "Working for Justice," 255.
} 
of the University of Chicago and Anna Holden, the National Secretary of CORE, all participated. ${ }^{35}$

At the 1961 NCClJ convention in Nashville, Dianne Nash was a featured speaker. Raised in Chicago where she attended Catholic school, Nash had enrolled at Fisk University in 1959 where she became active in the sit-in movement. She later dropped out of school and joined SNCC as a full-time community organizer. Nash described her experiences as a Freedom Rider and demanded that Catholics forthrightly address the racial issue. Chastising the Church for its failure unequivocally to condemn racism she asked, "If this is not an area in which the Church must work, what is?"36 As the movement gained momentum, Catholic participation in demonstrations escalated, and the $\mathrm{CICs}$ were forced to decide whether to engage in the tactics of nonviolent protest. That year the NCCIJ passed a resolution supporting the participation and laity and clergy in nonviolent direct action. ${ }^{37}$ But to date, no Catholic organization had participated in or sponsored a non-violent demonstration.

Following the Freedom Rides, two New Orleans priests, Phillip Berrigan, S.S.J., and Richard Wagner, S.S.J., attempted to join a CORE demonstration. As Josephites, both men were heavily involved in the interracial apostolate. Berrigan taught at St. Augustine's, a black Catholic high school, and Warner was

\footnotetext{
35 For accounts of Catholic participation in the Freedom Rides see Terry Sullivan, "What is it like to be a Freedom Rider?" and Anna Holden "A Call to Catholics," Interracial Review, (June, 1961), 143-145.

36 Diane Nash, "Inside the Sit-ins and Freedom Rides: Testimony of a Southern Student" in Ahmann, The New Negro, 43-60.
} 
a chaplain at Xavier University, the only black Catholic university in the country. James Farmer, Director of CORE had issued a call to priests, rabbis and ministers to fly into Jackson, Mississippi and integrate the local airport. Berrigan and Wagner flew to New York where they spoke with Farmer about the plan. Farmer warned them that the trip posed a considerable risk of violence. Before they boarded a flight from New York to Atlanta, Berrigan called Frank Hall at the NCWC News Service and read a statement declaring their intentions. The two explained that they had received permission for their actions from their superior in Baltimore. Philip's brother, Father Daniel Berrigan, S.J., had requested permission from his superior but had been turned down. Philip Berrigan informed Hall that he was "confident" the two would be arrested when they reached Jackson.

Hall called Father George O'Dea, S.S.J., Superior of the Society of St. Joseph, and reported the "rather bizarre incident."38 He asked O'Dea to confirm the story. O'Dea admitted that he had given the priests permission but was forced to retract it. Bishop Richard Gerow of Natchez had somehow learned of the plan and informed O'Dea that if the two went to Jackson, he would expel the Josephite order from his diocese. ${ }^{39}$ Protocol required that whenever a

37 NCCIJ (1963). "Statements on Direct Action." NCCIJ. Unpublished.

38 Frank Hall Letter to Paul Tanner. August 22, 1961. Unpublished. CUAA. NCWCP. Box 89 File 14. See Also Philip Berrigan. "Statement," August 21, 1961. Unpublished. CUAA NCWCP. Box 89 File 14.

39 Hall Letter to Tanner. On Gerow threat see Freidland, Lift Up Your Voice, 54. Hall seems to have misunderstood the plan and mistakenly identified the priest as wanting to "join the Freedom Riders." 
clergyman or religious enter another diocese, he ask the local ordinary permission to perform any public acts. This was to insure that the authority of the bishop would not be undermined by anyone from outside his jurisdiction. The tradition had seriously limited Catholics' ability to respond to events in a diocese where the bishop did not support demonstrations. O'Dea paged Berrigan at the Atlanta airport and ordered the two priests back to Baltimore. 40 The incident was typical of Catholic involvement in direct action. There was no clearly articulated vision of what the role of a Catholic priest should be in nonviolent demonstrations or how the issue of ecclesiastic jurisdiction should be approached. By the early 1960s Catholic interracialists had developed a highly sophisticated vision of what an integrated society would look like, but had very little idea about how to get there.

Not surprisingly, the first steps in addressing this issue of protest and authority were taken in Chicago, the new center for Catholic interracial activity. John McDermott had recently been appointed Executive Director of the Chicago CIC. He was representative of the new breed of Catholic interracialist-- active, educated, professional laymen who were willing to press the hierarchy on the issue of racism. McDermott had attended graduate school at Georgetown University on the G.I. Bill where he became involved with the Catholic interracial movement. After graduation he worked for the City of Philadelphia's Redevelopment Authority as a public relations specialist and a member of the 
City's Human Relations Committee. There he met fellow Catholic layman, Dr. Dennis Clark, the noted African American sociologist. ${ }^{41}$ Clark and McDermott founded the Philadelphia Housing Council (PHC). The PHC initiated projects to ease tensions brought about by neighborhood integration, and eventually affiliated with the Philadelphia CIC.

In 1960 McDermott moved to Chicago to be the executive director of the Chicago CIC. McDermott oversaw the first organized involvement of Catholics with non-violent direct action. The program at the Chicago $\mathrm{CIC}$ when he arrived was an educational one on the LaFarge/CICNY model. He recalled:

I had inherited a good program, but basically it was an educational program. And then that was the time that the non-violent civil rights movement was just coming along. What I did was to bring the non-violent civil rights movement into harmony, or bring the Council into harmony with that a movement was coming along and we had to make a major decision: does the $\mathrm{CIC}$ believe in non-violent direct action, and to our credit we did. 42

In 1961 the Chicago CIC helped to organize demonstrations at Rainbow Beach, a public beach on the South Shore of Lake Michigan off $79^{\text {th }}$ Street in Chicago. The beach as not legally segregated, but local whites had prevented blacks from using the facility with threats of violence. The NAACP and CORE had targeted the beach earlier in the summer but were unable successfully to integrate it. Realizing that the area was heavily Catholic, the Chicago CIC sponsored a

40 Philip Berrigan. Fighting the Lambs War: Skirmishes with the American Empire. The Autobiography of Philip Berrigan, (Monroe, Maine: Common Courage Press, 1996), 58-59.

41 Clark's research on the sociological effects of segregation was used by the NAACP in the 1954 Brown v. Board of Education of Topeka, Kansas case.

$42 \mathrm{McDermott}$ Interview. 
"wade-in" to show Catholic support for integration and arranged for back demonstrators to be accompanied by priests. ${ }^{43}$

The following year, the nine members of the Chicago $\mathrm{CIC}$ traveled to Albany, Georgia to join civil rights demonstrations sponsored by Martin Luther King's Southern Christian Leadership Conference. They went as part of an ecumenical delegation of Chicago clergy and laity, which was sponsored by the United Church Federation. The group was responding to King's appeal for concerned citizens to join his protest. They were arrested while conducting a prayer vigil on the courthouse steps. ${ }^{44}$ One participant, a Catholic college student from Marquette University, described his feelings at being told the local Catholic priest refused to visit him in jail. "I was at once shocked and hurt," he wrote "that a priest of my own faith could not act so."45 For most of the Catholic participants, this was their first trip into the Deep South and few were prepared for the depth and tenor of Southern racism. The Chicago CIC heralded the nine as the "largest group of American Catholics that has participated in the nonviolent movement." 46 The statement was an unfortunate admission of the state of Catholic involvement in direct action. In addition to indicating the small number of participants, the Chicago $\mathrm{CIC}$ itself was perhaps the only group who

\footnotetext{
43 Ibid. See also John McDermott "Wade-in Witness at Rainbow Beach, Interracial Review (June, 1962), 146-147. McGreevey, Parish Boundaries, 142. William Hogan, "Wade-In at 'Rainbow'” Community 21 (October, 1961) 4-6.

44 Zielinski, "Working for Justice," 255.

45 "Why We Went to Albany: A Report by the Catholic members of the Chicago Interreligious Delegation." Cited in McGreevey, Parish Boundaries, 142. 46 Ibid.
} 
knew that the participants were Catholics. The press covering the Albany movement made no mention of the group's religious affiliation.

In 1963 the Chicago CIC organized a demonstration at Loyola University in Chicago to protest the discriminatory practices of the Illinois Club for Catholic Women (ICCW). The ICCW was a social club that organized charitable events. It met on the downtown campus of Loyola University in Lewis Tower, a building that the husband of Julia Lewis, the president of the club, had donated to the University. The club was open to all women attending Loyola except African Americans. The Chicago $\mathrm{CIC}$ made ten separate attempts to arrange a peaceful resolution to the problem over a two-month period. 47 Lewis cited the numerous charitable works the club engaged in, and then defended the club's membership policy on the grounds that forced integration might jeopardize their ability to raise money for its welfare programs. "We too are entitled to civil rights," she declared, "[and] we are taking them." 48 She even denied that African American women wanted to join the ICCW. 49

The Council decided to picket, and on July 1, 1963, six Franciscan Sisters and Father Daniel Mallette of St. Agatha's Parish in Chicago carried placards in front of Lewis Tower. ${ }^{50}$ McDermott announced that demonstrations would begin immediately. He stated:

\footnotetext{
47 "Religious Picketing of ICCW Defended." The New World, July 23, 1963. 48 Ibid.

49 Dave Meade, "Club's Racial Policy Stirs Loyola Students," Chicago Daily News June 29, 1963. 50 lbid.
} 
As a general policy, $\mathrm{CIC}$ will use direct action methods only after serious consideration and as a last resort after ordinary methods have been tried and found wanting. We believe that peaceful demonstrations against racial injustice can be an effective and proper means for Catholics to give witness to the principles of their faith. Carefully and prayerfully conceived, we believe these actions can sometimes achieve reforms where ordinary methods fail. 51

The previous summer the nuns had attended a seminar on race relations sponsored by the Chicago CIC. That spring the sisters had listened to a member of the Albany delegation recount her experience in Albany. She challenged the sisters to join the civil rights movement and man the picket lines. ${ }^{52}$ The sight of the Sisters shocked Lewis. Within days she agreed to alter the membership policy of the club. Lewis son's asked "why women in $18^{\text {th }}$ century garb with $19^{\text {th }}$ century rules, should suddenly vault into the 20th century." 53

Lewis' son's reaction to the presence of the Sisters was understandable, Catholic women religious held an esteemed place in the American Catholic milieu, and the image of nuns picketing was at odds with most Catholics' view of the proper place for nuns. Two of the nuns discussed the reasons for their participation. Sisters Anthony Claret, O.S.F. explained, "We did this not just because we were students at Loyola and teachers; we did this most of all because we are religious." Sisters Angelica added that criticism of their participation indicated a "serious lack of understanding of just what is the

51 "CIC Replies to Criticism of Nun Pickets." The New World, July 19, 1963.

52 McGreevey Parish Boundaries. 144.

53 lbid. 
Church."54 Sisters were not immune from the social and cultural changes that were taking place in the country, and since the 1940s, they had been questioning their place in society.

That movement, known as the Sisters Formation movement (SFM), began as a candid evaluation of the state of Catholic secondary education in the United States in the early 1940s. The Sisters were concerned with the professionalization of Sisters-educators at a time when many states were adopting new standards and certification requirements. Catholic educators were acutely conscious of a negative attitude held by the public towards Catholic education. To counteract this perception they sought to match or exceed the new state standards. Many of the key leaders of the SFM were educators and played prominent roles in the National Catholic Education Association (NCEA). 55 Young women, who often entered their orders as early as age sixteen, were given very little and in some case no formal training. They were not expected or encouraged to obtain their bachelors degree before embarking on their career as educators. ${ }^{56}$ By raising the quality and level of training each Sisters received, it was hoped that the public perception of parochial schools would improve. They also urged orders to reform the rules, which dominated the lives of women

\footnotetext{
54 Sisters Angelica and Anthony Claret, "The Nun's Story: Why We Picketed." Community 22 (February 1963), 4-5.

55 Two works contributed most to the beginnings of the emerging movement. In 1941, Sisters Bertrand Meyers, D.C. published The Education of Sisters, and in 1949, Sisters Mary Madeleva Wolff, C.S.C., gave a report to the NCEA entitled "The Education of Our Young Religious Teachers."

56 Ibid, 9.
} 
religious and often made it extremely difficult for them to perform their duties. ${ }^{57}$

The Vatican encouraged the reform efforts in 1950 and 1951.58

In 1952 the NCEA members met to discuss the issues Rome had raised. ${ }^{59}$

The result of the Sister's discussions was the Sisters Educational and

Professional Standards Commission. Later renamed the Sisters Formation

Conference (SFC), it was the first organization created, staffed and concerned

with issues facing American Catholic women religious. SFC Institutes were

established to promote and direct in-service training for Sisters who were already

involved in ministry. The Conference also encouraged women religious to

pursue a liberal arts education, including coursework in theology and philosophy

57 Elizabeth Carrol, "Reaping the Fruits of Redemption," in Midwives for the Future: American Sisters Tell Their Story, ed. Ann Patrick Ware (Kansas City, Missouri: Leaven Press, 1985). 55.

58 Mary Schneider, "The Transformation of American Women Religious: The Sisters Formation Conference as Catalyst for Change (1954-1964)," Unpublished paper prepared for American Catholic Studies Seminar, Cushwa Center for the Study of American Catholicism, University of Notre Dame (February 6, 1986), 5. Schnieder also notes that the Papal support for these activities was seen as a further clarification of Pius Xl's statements on matters of education. Unigenitas Dei Filius (1924) had emphasized the necessity for theological training in all clerics [no women were given theological education] and in his apostolic letter "Christian Education of Youth" where he noted that "perfect schools are not so much of good methods as of good teachers ..." The predecessors of the Sisters Formation movement took these statements and applied them to themselves in light of the more recent Papal pronouncements, 4-5. The 1950 General Conference of the Sisters of Perfection called for a return to the particular charism of each order's founder. A year later, Pius XII convened the International Congress of Teaching Sisters in Rome. At the conference he stressed that each order should reevaluate the means by which they conduct their ministries, noting "it would not be reasonable to persist in customs and forms that hinder the service [to Christ] or perhaps render it impossible."

59 The results of this group were compiled in a Masters thesis, written the following year at Marquette University, by Sisters Mary Richardine Quirk, B.V.M "Some Present Day Problems in the Education of Teaching Sisters in the United States" (Unpublished M.A. Thesis, Marquette University, 1953) The group identified three areas that required attention: the lack of support among superiors and bishops as to the necessity of having Sisters complete their bachelors degree before entering a community; the lack of understanding of the issues facing Catholic education among Sisters themselves-- especially as to the necessity of a full education and continued training; and the lack of financial and institutional resources. Another NCEA panel was convened to discuss these problems in 1953. 
as well as masters and doctorates. ${ }^{60}$ The first chair of the SFC, Sr. Mary Emil Penet I.H.M., declared that Sisters Formation stood "not only for the education of the Sisters in a formal and informal sense, but for all the influences spiritual and intellectual, formal and informal, pre-service and in-service, which go to make a better religious and a better professional person." ${ }^{61}$

The SFC had opened the doors of the convent and pushed the Sisters into a complex and dangerous world. Many Sisters looked forward to the challenges that would now confront them, while others were more wary of the opportunity. Many of the orders worked among the poor, among African Americans and Native Americans, in rural and urban areas, and the Sisters had seen for themselves the effects oppression, poverty and despair had on these communities. But for the first time Sisters were speaking out on the political and moral question of the day. In order to promote the cause of interracial justice, the SFC established a close relationship with the Catholic interracial movement. ${ }^{2}$ It sponsored joint efforts with local orders, NCCIJ and local CICs. The Sisters

60 Schnieder, "Transformation," 14. Traxler Interview by author January 12, 1994. Various orders in the U.S. founded Sisters Formation colleges while others affiliated themselves with existing Catholic institutions. As the SFC pushed for greater number of Sisters to pursue their doctorates, it became apparent that the Sisters Formation colleges could not place all the candidates in teaching positions. The SFC affiliated itself a number of historically black colleges who needed a certain number of faculty with doctorates in order to keep maintain their state accredation. 61 Sisters Mary Emil Penet, "Progress A Report on Sisters Formation" in Sisters Formation Bulletin (Summer, 1956), 1. Cited in Schnieder, "Transformation," 8.

62 "Minutes of the Everett Workshop Meeting," July 8, 1956. MUA SFCP. 
Formation Conference Bulletin, the SFC's journal, carried news and covered events relating to interracial justice. 63

The Sisters Formation movement, like the Catholic interracial movement, created a theoretical and organizational base of support that prepared Sisters for involvement in the civil rights movement. Sisters Ritamary Bradley, editor of the Sisters Formation Conference Bulletin, noted:

These and other Sisters were moving out of a narrow ascetic tradition, with its "convent mysticism" of regulation and dependence, into a world that demanded a mature conscience. The emerging influences on all of us were from within the Church primarily. But there were also ecumenical influences and secular influences. We were now in touch with a community of rationality and moral insight on a broad scale. To this community belonged the disciples of Gandhi, teaching on nonviolence, and Martin Luther King, devising strategies against racism in the American tradition, and in his later years, brave initiatives (along with the Berrigans) for global peace. Contact with this world community of conscience, of moral insight, of inspiration was indeed "the world"-- but not in the sense of a danger to holiness or as opposite of "the convent". 64

The convent walls, which had isolated them, had been breached and with that freedom came a great deal of personal and collective responsibility. The participation of Sisters in demonstrations, as well as in religious renewal, argued Sisters Mary Berchmans Shea, O.S.U., were indicative of their "quest for identity as a person rather than in terms of a function or a role." 65 Like their male and lay

\footnotetext{
63 Schnieder, "Transformation," 19. Sisters Ritamary Bradley, C.H.M./S.F.C.C. from 1954-1964, edited the quarterly Bulletin. In 1954 the circulation was 100 readers; by 1964 the Bulletin was reaching an audience of 11,000 .

64 Ritamary Bradley, "The Truth Shall Make You Free," in Midwives, 74.

65 Sisters Mary Berchmans Shea, "Protest Movements and the Renewal of Religious Life," National Catholic Reporter, April 27, 196610.
} 
counterparts in the Church, sisters struggled to formulate an appropriate plan of action in addressing the challenge of racism in the Church and the world.

Three days after the Lewis Tower protest, the Baltimore CIC participated in a demonstration at the segregated Gwynne Oak Amusement Park. The NCCIJ had urged the local $\mathrm{CIC}$ to participate. ${ }^{66}$ Involved in the interfaith demonstration were nine diocesan priests and a large number of laymen. The group formed a barricade around the park and distributed a pastoral letter the Archbishop Lawrence Shehan of Baltimore had issued earlier that year. Two priests, Monsignor Austin Heady and Father Joseph Connolly, were arrested.

Responses to the demonstrations were varied, with some laity expressing outrage that the priests had been involved at all, while others supported the action. ${ }^{67}$ For the first time the national secular press noted Catholic participation. Both incidents made the national news section of Time. ${ }^{68}$ Father Connolly described his actions as fulfilling the "prophetic function of the Church." An article published in America under a pseudonym noted:

Gwynne Oak was not a pastoral letter; it cannot be put away unread. It happened. It was no generalized statement, but a concrete act. As Father Connolly said on Television: "Action makes the Church an effective prophet."69

After the initial demonstration, members of the Baltimore CIC participated in a picket line and continued to pressure Gwynne Oak to reverse its policy.

66 McGreevey, Parish Boundaries, 148.

67 Trueblood Mattingly (Pseudonym), "Gwynne Oak," America, August 10, 1963, 136-137.

68 "Civil Rights: The Force of Conscience," Time Magazine, 82:2 July 12, 1963, 17.

69 Ibid. 
Archbishop Shehan, a longtime supporter of the interracial movement, reprimanded the priests who took part in the demonstration and instructed "all our priests to abstain from organizing, or participating, in public demonstrations unless they shall have previously obtained permission."70 Monsignor Paul Tanner of the NCWC met with Shehan after the arrests and recalled his reaction to the incident:

The archbishop stated that he has directed his priests not to violate any trespassing laws. In retrospect he is happy that it happened on July 4th and does not object to the fact two of his priests were arrested. In the future, however, he wants them to avoid the possibility of arrest because demonstrations ending up in arrest too easily lead to violence. ${ }^{71}$

The New York Times called the protest "the first [interreligious] directed concerted protest against discrimination," while a letter to the editor of the Baltimore Sun referred to the actions of the "rabble-rousing priests"72

On the national front, the Catholic interracial movement was affected by two major events in 1963. The first was the National Conference on Race and Religion (NCRR). The Conference was the idea of Matt Ahmann of the NCCIJ who felt that the time had come for an interfaith dialogue on the race question. It took place in Chicago at the Edgewater Hotel, January 14-17, coinciding with the 100th anniversary of Lincoln's Emancipation Proclamation. An ecumenical affair, the NCRR was sponsored by the Department of Racial and Cultural Relations of the National Council of Churches, the Social Action Committee of the Synagogue

\footnotetext{
70 Mattingly "Gwynne Oak," 137.

71 Paul Tanner, "Meeting on Race Relations," July 12, 1963. Unpublished. CUAA NCWCP. Box 89 File 15.
} 
Council of America, and the Social Action Department of the NCWC. Eight hundred attended the conference, including twenty-four Roman Catholic Bishops and a Roman Catholic Cardinal. ${ }^{73}$ Other notable attendees were Archbishop Germanos of the Greek Orthodox Church, Rabbi Julius Mark of the Synagogue Council of America, Dr. Irwin Miller of the National Council of Churches, and Sergeant Shriver, brother-in-law of President Kennedy, Director of the Peace Corps and longtime Chicago CIC board member. Martin Luther King, Jr. gave the keynote address. He called upon all denominations to take action, declaring that they had forsaken "their prophetic mission on the question of racial justice."74

The NCRR concluded by issuing a joint statement on racism. Entitled, "An Appeal to the Conscience of the American People," the statement was further justification for the aims of the interracial movement. It described racism and segregation as "an insult to God."75 That the various groups had worked together in fashioning such a document held out the promise of further cooperation on a more active, rather than intellectual, level. John McDermott remembered:

It became the one issue where the major faith groups could work together very closely; pressing national issues, pressing moral issues with no theological disagreement on the issue or what had to be done. And the byproduct was that a lot of friendships were made, a lot of trust relationships were created, a lot of myths and prejudices and shibboleths faded away. ${ }^{76}$

72 Mattingly, "Gwynne Oak," 137.

73 Zielinski, "Working for Justice," 255.

74 LaFarge, "Religion and Race Meeting," America, February 2, 1963, 159. See also McDermott Interview. King quoted in Southern, Limits of Catholic Interracialism, 347.

75 "An Appeal to the Conscience of the Nation." Cited in Zielinski "Working for Justice," 257.

76 McDermott Interview. 
Many participants were introduced to each other for the first time at the conference. These personal contacts would prove to be invaluable when it came time for organizations to cooperate. After the NCRR, a Chicago-based ecumenical gathering, modeled on the NCRR, was established. The Chicago Archdiocese, the Church Federation and the Board of Rabbis sponsored the Chicago Conference on Religion and Race. Eugene Callahan, a professor at Loyola, served as Executive Director. ${ }^{77}$ Other local conferences were initiated to promote interracial justice in cities throughout the nation. ${ }^{78}$

The second event affecting the Catholic interracial movement that year was the March on Washington. In August, thousands of men and women descended upon the nation's capitol to urge the passage of the Kennedy administration's civil rights bill. The SCLC, NAACP, SNCC and CORE cosponsored the March, which was a revival of A. Philip Randolph's original 1941 plan. While LaFarge had been the only Catholic, as well as the only white, involved in the first March, the 1963 March was an interracial and ecumenical affair. Catholics played key roles as organizers, participants and attendees. Matt Ahmann, as Executive Director of the $\mathrm{NCClJ}$, was appointed one of ten March chairmen. Platform

77 Ibid.

78 Areas that started local conferences on race and religion: Chicago IL, Peoria IL, South Bend IN, Marion IN, Gary IN, Waterloo IN, Des Moines IW, Lexington KY, the state of DE, Boston MA, Ann Arbor-Washtenaw MI, Kansas City KS, St. Louis MO, Syracuse NY, Rochester NY, the state of NC, the state of OK, the state of RI, Houston TX, Seattle WA, Washington DC, Milwaukee WI. Organizational efforts: Little Rock AR, Oakland CA, San Diego CA, Miami FL, Atlanta GA, Savannah GA, Joliet IL, Portland OR, New Orleans LA, Springfield MA, Detroit MI, state of MI, New York City NY, Cincinnati OH, Omaha NE, Pittsburgh PA, San Antonio TX. Matthew Ahmann, "NCRR Steering Committee Memo," August 14, 1963. CUAA NCWCP. The CCRR met from 1963-1973. 
guests included Archbishops O'Boyle and Shehan, Bishops Jerome Hannan of Scranton, Michael Hyle of Wilmington and Ernest L. Unterkoefler of Charleston, as well as Fathers LaFarge of the CICNY and Daniel Cantwell of the Chicago CIC. For Catholics, the March was the first civil rights event in which the Catholic Church was publicly identified with the civil rights movement, and it was the first event in which the Church played a role in organization and policy making.

While the leaders of the Catholic interracial movement were ecstatic over the level of Catholic participation, some bishops refused to allow their priests to attend. Many, including LaFarge, worried that the March might deteriorate into a riot. In July, LaFarge wrote Ahmann and confessed:

It is not pleasant to say these things. There may be good people who enjoy excitement and demonstrations, but for the most of us it is an unwilling task, one which we embark on not from any enthusiastic or revolutionary spirit, but simply because plain logic and honest faith drove us to this conclusion, as it drove the peaceful inhabitants of our original Thirteen Colonies in the summer of 1776.79

Father Matthew Gottschalk, O.F.M., wrote to the NCClJ to inform them that the Milwaukee chancery office viewed the march as "rash and imprudent" and had forbidden its priests to attend. 80

Nor was the event itself without conflict and crisis. A copy of SNCC director John Lewis' speech had been given to March organizers in advance. A copy was passed along to Archbishop O'Boyle who objected to the "incendiary" tone of John Lewis' speech with its martial language of "nonviolent armies" and

79 John LaFarge Letter to Matthew Ahmann. July 24, 1963. LaFarge Papers. Box 8, Folder 19.

80 McGreevey, Parish Boundaries, 197. 
"scorched earth policies." O’Boyle found Lewis' criticism of the Civil Rights bill as "too little, too late" particularly troubling since the March had been organized to support the pending legislation. ${ }^{81}$ That Lewis called patience a "dirty and nasty word" infuriated the archbishop. Bayard Rustin, chief organizer of the March, attempted to resolve the crisis that evening at the Statler-Hilton. Lewis felt that some of the objections had merit, but could not understand why O'Boyle was so upset over his use of word patience. He later recalled Rustin's explanation:

"This is offensive to the Catholic Church," explained Bayard. "Why?" I asked. I honestly had no idea.

"Payyy tience," Bayard said, drawing the word out, as if that made it clear to me. "Catholics believe in the word patience." 82

However, after the evening meeting not all parties were satisfied with the changes. The argument resumed the next day, and O’Boyle told March organizers that he would not give the invocation if the speech were not changed. Rustin recognized how important maintaining the support of the Roman Catholic delegation was and promised the Archbishop that the speech would be acceptable by the time it was delivered. O'Boyle agreed and gave the invocation while negotiations with Lewis continued in a guardroom under the statue of Lincoln. A. Philip Randolph, Bayard Rustin, Eugene Carson Blake, a

81 On SNCC's objection to the pending legislation see Carson, In Struggle, 85-88.

82 Lewis, Walking with the Wind, 219. See also Kristine LaLonde, Transfromations of Authority: Reform, Rebellion, and resistance in the Catholic Church of the 1960s. (Ph.D. Dissertation: University of Virginia, 2001), 173-175. 
Presbyterian minister from the National Council of Churches, and King finally persuaded Lewis to rework the offensive passages. ${ }^{83}$

A large number of dioceses were represented at the March. Some carried signs and placards identifying their diocese, order or organization. Chicago priest Father Francis Kearns noted of the experience, "No one can say that the drive for human dignity and civil rights in the United States is simply a political effort. At this stage, it is a deeply religious movement, and the March on Washington was also a religious meeting." ${ }^{4}$ Another priest described the event as "marching the mass" - carrying the Eucharist from the altar, over the communion rail, out of the Church and into the streets of the capital. 85 The event was a major accomplishment for the aging LaFarge who at 83 had only a few more months to live. He had traveled from segregated black parishes in Southern Maryland to center stage at the largest public ecumenical social justice rally of the twentieth century and had quietly shepherded the Roman Catholic Church along with him.

Serious questions, however, remained about the proper role of participation by the laity, clergy and religious, and Catholic participation in demonstrations remained sporadic and uncoordinated. On July 28,1963 , the NCCIJ passed a resolution not only supporting the use of direct action nonviolent techniques, but also called for the NCCIJ and member CIC's to actively train their

83 Cf: Taylor Branch Parting the Waters: Martin Luther King and the Civil Rights Movement, 19541963 (London: Macmillan, 1988), 874-880. See also Ibid, 217-224.

84 Francis Kearns, "Marching for Justice," Commonweal 78, September 20, 1963, 553. 
members in those techniques. ${ }^{86}$ Priests and nuns participated in an ecumenical, round-the-clock vigil at the Lincoln Memorial in support of the Civil Rights bill. That spring, two Boston priests were arrested in North Carolina for integrating a local restaurant. Their superior, Monsignor George Casey, exclaimed, "They couldn't stand to see the place of danger wholly occupied by Protestants, Jews and non-believers, with the Catholic Church home in safety, composing nice statements by way of compensation." 87 Later that year, a number of priests and laity participated in the Freedom Summer Project in Mississippi, a SNCC led voter registration campaign. ${ }^{88}$ However, the question of episcopal approval, clerical involvement and the right of priests and laity to cross into another diocese to protest had not been addressed.

In December, 1963 Father Thomas Carroll, Director of the Boston Catholic Guild for the Blind, wrote to Father Dennis J. Geaney, O.S.A., to discuss a plan to involve more clergy in the Southern civil rights demonstrations. Carroll respected the attempt by Berrigan and Wagner to join the Freedom Rides two years earlier, but was keenly aware of the problem posed by ecclesiastical authority and jurisdiction. Carroll hoped that a group of priests might be formed in which members would sign a pledge declaring their willingness "to put themselves on the line in a demonstration provided that it were not contrary to

\footnotetext{
85 Ronald Luka C.M.F., "We Marched the Mass," Ave Maria 98 (November 2, 1963), 10,28. 86 "NCCIJ Statements on Direct Action." CHS Monsignor Daniel Cantwell Papers (DCP). Box 32, File "Race Relations September-December 1963."

87 George Casey, Homiletic and Pastoral Review 64 (October 1964), 1036.

88 McGreevey, Parish Boundaries, 152.
} 
the wishes of the Ordinary in the area to which they were going, and provided that they had the requisite permission of their own superiors." 89 Carroll modeled the pledge on the oath taken by the Order of Our Lady of Mercy. The Mercendarians, as they were commonly known, were established in Spain in 1218 for rescuing Christian captives from the Moors. The priests took a vow in which they promised to offer themselves up for the ransom of captives. Carroll noted that in 1964 they still took a fourth vow "to become hostage among the infidels if required." 90 He recognized that the creation of a new order was unfeasible and that a complete identification with the civil rights movement would limit a group's ability to function in the South. Instead, he envisioned a cadre of between 250 and 300 diocesan and religious priests from across the country serving as a sort of Catholic civil rights rapid deployment force..$^{91}$

Carroll sent invitations to priests across the country involved in the interracial movement to discuss "how the Church might witness her concern and Christ's concern for the Negro."92 Twenty-four of the twenty-nine priests he contacted agreed to attend. ${ }^{93}$ On March 8 and 9 the group met as the "Priests' Rights Committee" at the Americana Motel in Chicago to discus Carroll's proposals. Attending were: Father Eugene O'Boyle, Father Daniel Cantwell of

\footnotetext{
89 Thomas Carroll Letter to Dennis Geaney. December 5, 1963. CHS DCP. Box 32, File "Race Relations December 1963."

90Thomas Carroll Report on Priests' Meeting on Rights, 2. CHS DCP. Box 32, File "Race Relations January March 1964." On the Mercendarians see Catholic Encyclopedia, J. M. Besse The Catholic Encyclopedia, Volume X Copyright (C 1911 by Robert Appleton Company Online Edition 1999 by Kevin Knight.

91 Thomas Carroll Letter to Geaney. See also McGreevey, Parish Boundaries, 151.
} 
the Chicago CIC, Monsignor Joseph Connolly, Father John D. Conway of the Washington, D.C. CIC, Father John Cronin, S.S., of the NCWC, Father Dennis Geaney O.S.A., Monsignor George Gingras of the Washington, D.C. CIC, Monsignor Austin Healy of the Baltimore CIC, Father William Hogan, Father John LaBauve, Father Rollins Lambert, Father Eugene McManus, Father John Morris, Father Marvin A. Mottet, Matthew J O'Rourke, Monsignor Harold Perry, S.V.D., Father Herman Porter, Monsignor William Quinn, James Sheehan, Father John Shocklee, Father Sherrill Smith of San Antonio, Father James Stewart, Father August Thompson. ${ }^{94}$ Carroll chaired the meeting.

The minutes of the meeting note that many of the attendees were disturbed by the lack of opportunity to participate in the civil rights movement, while clergymen of other faiths had "departed as potential martyrs into areas of Southern injustice."95 These restrictions compromised the priests' ability to work in the black community. The result of this "multifold scandal" was threefold: opportunities for ecumenical cooperation were sharply reduced, white Catholics remained indifferent to the issue of racial justice, and the African American community continued to regard the Catholic Church as a pawn of the status quo.96 And while the committee was disappointed with the present level of

92 Carroll, "Report on Priests' Meeting on Rights," 2.

93 One priest was unable to make the meeting due to illness.

94 "Lists of Priests Attending Meeting at the Americana Motel," March 8-9,1964. CHS DCP. Box 32, File "Race Relations December 1963."

95 Carroll, "Report on Priests' Meeting on Rights," 1.

96 Ibid. 
participation in the protest movement, it recognized "the importance of canon law and orderliness in Church procedures."97

The committee naively concluded that the real obstacle to the participation of clergy in civil rights demonstrations was not lack of ecclesiastical support, but a paucity of priests in local dioceses willing or able to undertake such actions. The committee proposed the formation of a group of priests who would consent to undertake the mission of offering themselves as public witnesses at the discretion of the local ordinary who would temporarily release them from their obligations. The final decision on participation would be left to the local bishop who could withdraw it at any time as local circumstances warranted. The committee made it clear that it did not seek to embarrass the local ordinary. It was decided that no permission was needed from the hierarchy for "a group of priests to establish a quiet organization for the purpose of carrying out the encyclicals" although officers would need to get permission of their own ordinary to become members of a society outside of their diocese. The committee proposed two forms of membership: one in which the priest, with permission from his superior, agreed to participate in demonstrations, and one in which the priest "merely showed the priest's sympathy for the aims and purpose of the organization."98

A nine-member governing board was established that consisted of six elected members who then chose the remaining three. The committee issued a

97 Ibid. 
five-point declaration of principles that reflected the new rights language

priests were adopting from the civil rights movement. The statement declared:

1. Our bishops, individually and collectively, have spoken strongly and frequently on the matter of human rights. This group of priests is being formed to help implement these directives and to give witness without which the mission of the Church will be disastrously compromised.

2. In the face of the continuing Civil Rights crisis and the indispensable role of the Church in the situation, the members of the committee feel obliged in conscience to address themselves to the problem by being involved in obtaining freedom for all the children of God.

3. The conscience of the total religious community can best be stirred by the clergymen of various Communions standing shoulder to shoulder in their involvement. In the era of ecumenism, joint, practical exercises of the works of justice and charity should be in evidence.

4. Recognizing that it is the same Holy Spirit Who places the bishops in the rule within the Church, and Who also stimulates the conscience of individual priests, we express our complete acceptance of the principle that the exercise of individual conscience must be responsive to episcopal authority.

5. In the face of increased activity and mounting tension, the members of this committee stand ready to give witness by direct action wherever the local ordinary welcomes such help. As the bishops have reminded us that the heart of the question is moral and religious, the members of this Committee envision their witness as being moral leadership motivated by divine charity. ${ }^{99}$

The group recommended the establishment of a "House of Studies" which would act as a headquarters for organization. The center would provide educational programs on social justice issues and training in nonviolent demonstration techniques. The center would support scholarly research and publish articles and books on related subjects, and serve to coordinate the activities of its

98 Ibid, 4.

99 Thomas Carroll, "5 Point Mission Statement." CHS DCP. Box 32, File "Race Relations December 1963." 
members with local bishops and the hierarchy. 100

But the members of the Priests Rights Committee were surprised at the reaction of bishops and superiors. The Committee faced the same antipathy LaFarge had encountered thirty-one years earlier with the surprised Clergy Conference on Negro Welfare. None of the bishops the group approached were willing to give permission for the purpose of priestly witness even with the stipulation that the group required approval of the local ordinary and a priest's superior. Carroll wrote to the committee members to inform them of the difficulties. "In the meantime," he wrote, "in specific situations we may be able to get the permission for some kind of involvement." He pointed out that Bishop Joseph Reed of Oklahoma had permitted two of his priests to go to Hattiesburg, Mississippi to take part in a voter registration campaign, and Cardinal James Ritter of St. Louis has just appointed one of his priests as full time secretary to the Archbishop's Commission on Human Rights with full powers to mobilize the Catholic community and to hasten the attainment of full equality and freedom. ${ }^{101}$ As of 1964 , individual conscience and authority posed contradictions that remained, for the most part, unresolved despite efforts to address them on the part of Catholic clergy, religious and lay men and women.

The main tenets of the Catholic interracial movement had gained acceptance among many bishops and Catholic scholars, but many others

\footnotetext{
100 Thomas Carroll, "Proposed Form and Position Paper." CHS DCP. Box 32, File "Race Relations April-August 1964."
} 
remained indifferent, if not openly hostile, to the social revolution sweeping the country. By 1960 a new generation of leaders was struggling to mobilize the resources of the Church to fully implement the principles of equality and brotherhood. The NCCIJ and the renewed efforts of Catholic Interracial Councils signaled a new era of engagement by Catholics, especially Catholic laity, with social issues on the national scene, but they remained, in LaFarge's words, "an effective minority." Nor had laymen and women fared any better at unraveling the tangled issue of individual conscience and authority. Catholic participation in the civil rights movement was limited to the impulsive activities of small groups and individuals and the more organized educational programs of the NCCIJ. Both groups' activities were concentrated in the urban North and in some border states like Missouri and Maryland. The former set precedents and inspired Catholics to take greater risks to press for further involvement in the Southern civil rights struggle. The latter created an important network of contacts with civil rights organizations and leaders.

101 Thomas Carroll, "Current Status Letter" May 14, 1964). CHS DCP. Box 32, File "Race Relations December 1964." 


\section{Chapter 3 : "The harvest indeed is great."}

"The harvest indeed is great, but the laborers are few"

Matthew 9:35; Luke 10:2

The Catholic Interracial movement was almost exclusively a Northern movement. As LaFarge and others leaders formulated a Catholic vision of a racially integrated society, Catholic missionaries in the South labored to bring the faith to African Americans within the strict confines of segregation. These missionaries were not concerned with a theoretical defense of interracialism but with the practical needs of their parishioners. Catholics had firmly established themselves politically, socially and culturally in the North, but in the South Catholics were a distinct minority. The issue of race further marginalized not only black Catholics but also the whites who worked among them. The establishment of these black Catholic communities provided important resources for all African Americans as they struggled to live under Jim Crow, and later as they fought to dismantle it.

The Bishop of Alabama, Thomas J. Toolen, had encouraged Catholic evangelization among African Americans in his diocese since he became bishop in 1927. In 1937 Toolen wrote to Father J.B.Tennelly, S.S. of the Commission for the Catholic Missions among Colored People and the Indians to implore for more funds. "We are face to face with the fact that we must win them now or lose them forever," he said, "and yet how are we to win them unless those in 
more prosperous dioceses help us."1 As a result of his modest acts on behalf of Alabama's black Catholics, Toolen was labeled the "nigger bishop" by the Klan. ${ }^{2}$

Toolen was born in 1886 in Baltimore. He was ordained to the priesthood in 1910, and served the St. Bernard's Parish in Baltimore for 15 years. In 1927 he became the sixth Bishop of Mobile. ${ }^{3}$ His diocese of 40,000 Catholics encompassed all of Alabama and a portion of the Florida panhandle. The cities of Birmingham, Mobile and Pensacola had large and vibrant Catholic populations, while the remaining Catholics were spread throughout the diocese in rural areas. ${ }^{4}$ In the cities, a parish structure very similar to the urban parishes of the North had developed. There priests were available to administer the sacraments to their parishioners regularly. However, in the countryside and in the smaller cities, priests were few and parishioners scattered. Catholics made up only $3 \%$ of the predominantly Protestant population, and while the city of Mobile could lay claim to a pre-colonial Catholic history, most of Alabama viewed Catholics as dangerous outsiders. W.J. Cash in his seminal work, the Mind of

1 Commission for the Catholic Missions among Colored People and Indians. Thomas J. Toolen Letter to Tennelly. September 25, 1937. Archdiocese of Mobile Archives (ADMA) Box 1937, File: "Missions Negroes and Indians."

2 Oscar Lipscomb Interview by author (February 3,1997).

3 Oscar Lipscomb. "Thomas Joseph Toolen." New Catholic Encyclopedia Vol. 17 p. 667. The Diocese of Mobile became the diocese of Mobile-Birmingham in 1954, and included portions of the Florida panhandle until 1968. In 1969 the diocese of Mobile-Birmingham was separated into two dioceses. Although the Diocese of Mobile was not elevated to the status of an Archdiocese until 1980, Pius XII in 1954 awarded Toolen the title "Archbishop ad Personam." Therefore he is referred to throughout most of this work as Archbishop Toolen.

4 Andrew Moore, "Catholics in the Modern South: The Transformation of a Religion and a Region, 1945-1975," (Ph.D. Dissertation: University of Florida, 2000), 27. 
the South, wrote that Protestant Southerners saw Catholics as "the intolerable alien, the bearer of a Jesuit plot to rob them of their religion by force." 5 Therefore, much of Toolen's energy was directed toward three goals: maintaining the faith of Catholics, defending their faith against attacks from enemies, and evangelization.

He was the prototypical pre-concilar brick and mortar prelate. His diocese was a mission territory and most of the money that Toolen raised came from sources outside the South. Toolen had ambitious plans to expand the institutional infrastructure of the diocese in the hopes of strengthening the Catholic community there. In 1945 he announced a "four million dollar plan" which would build parishes, schools and hospitals throughout Alabama. ${ }^{6}$ The son of Irish immigrant parents, Toolen maintained close ties to his parents' homeland, taking yearly trips there to recruit priests for his diocese. ${ }^{7}$ Priests and religious worked throughout the diocese to reclaim lapsed Catholics and convert non-Catholics using methods that in many ways mirrored their Protestant neighbors. But it was evangelization among the large African American population that posed a unique set of problems for Toolen.

Race was the crucial issue that confronted Southern Catholics. The social gains made by the Catholic community in the South were in part the result of a Faustian bargain. In supporting the "Southern Way of Life," in particular its racial

5 Wilbur J. Cash, The Mind of the South, (Knopf: New York, 1941), 342.

6 "Diocese to Spend Four Million Dollars," The Catholic Week, Nov. 16, 1945, 1.

7 Archbishop Oscar Lipscombe Interview by author. (February 3, 1997) 
mores, Southern Catholics were beginning in the 1940s to enter the public arena as equals with their Protestant neighbors. With the end of the Second World War and the advent of the Cold War, Catholics could point with pride to their participation in the war effort and to their impeccable anti-Communist credentials and stake their claim to full membership as Southerners. Historian Andrew Moore has noted:

Catholics would wear the "intolerable alien badge" for only so long. Their patriotism and commitment to democracy and religious liberty should be indisputable. Southern Catholics asserted their right to be taken seriously in the larger society. In their minds, they and their message were to be acknowledged and heeded not in spite of their Catholicism but because of it. 8

However, this statement held true for Southern white Catholics only. Unlike Catholics in the urban North whose ethnic identities differentiated Catholic groups from each other, Catholics in the South were placed into two clearly marked groups. The ethnic distinctions among Italian, English, and Irish Catholics were transmuted into a generic white Catholic identity. The very same process relegated the few black Catholics to a double outsider status in the South. The price white Catholics had to, and were willing to, pay for entry into the center of Southern life was the vigilant maintenance of segregation.

The Church used public ritual to reinforce its vision of the social order. In establishing the feast of Christ the King in 1925, Pius XI had warned of "the plague of anti-clericalism, its errors and impious activities" and worried about the

8 Moore, Catholics in the Modern South, 87. 
"decline of public authority, the lack of respect for the same." 9 The public display was meant to reinforce the idea that salvation was through Christ and his sacrifice, which in turn was made available to the faithful through the priests who were to be obedient to their bishop who was Christ's representative. Everyone had his place in the divinely instituted order. And while salvation was potentially available to all, that in no way implied either a spiritual or social equality. ${ }^{10}$ Thousands of Catholics attended the feast day celebrations, which were organized by the Holy Name Societies in each parish. Being a Southerner and a Bishop, Toolen believed fervently in a strict social and theological hierarchy. The annual Christ the King celebration was held every November 25 as an "outward demonstration of faith," and was meant to serve as a clear model for the Catholic social order that Toolen envisioned. ${ }^{11}$ The largest celebration took place in Mobile. Mobile's parochial school children were required by Toolen to attend and participate in the parade, which necessitated the presence of their parents. Not only was the public ritual meant to reinforce a particularly Catholic vision of the social order, but to demonstrate to non-Catholic Southerners that the Church was in full compliance with Jim Crow. African American Catholics were notably

9 Pius XI, Quas Primas, December 11, 1925 in Claudia Carlen I.H.M., (ed.), The Papal Encyclicals, 1903-1939, (Wilmington, NC: McGrath, 1981) 276.

10 For a further analysis of Nineteenth century models of Church authority see Jay Dolan, The American Catholic Experience: A History from Colonial Times to the Present. (Notre Dame: University of Notre Dame Press, 1992), 221-225.

11 "20,000 Mobile Catholics Honor Christ the King," Catholic Week November 2, 1945. 1. Cf. Moore, Catholics in the Modern South, 97-113. 
relegated to the rear of the parade, where they were both a part of the church and apart from the church.

Toolen considered himself a liberal on the race question. His liberalism, however, was shaped by an older, more conservative generation. He built parishes, hospitals and schools for African Americans, but within the established system of segregation. Toolen balanced his obligation to proselytize African Americans with the need to safeguard the recent gains made by white Catholics. Without ever directly confronting the system, Toolen worked and hoped for the gradual demise of segregation as a result of the Church's work. What enabled Toolen to walk this tightrope was the sheer force of his personality and the unquestioning loyalty he demanded from his subjects.

Father Albert Foley, S.J., a liberal Catholic sociologist, taught at Spring Hill College in Mobile. Toolen often stymied Foley's modest efforts in the field of interracial justice. In the early 1940s Foley attempted to form a bi-racial Catholic committee at the college. Foley recounts in his memoirs that Toolen required all priests working with African Americans "to operate behind the segregation lines and not push the blacks on whites in Alabama." Toolen claimed that he fully supported "the religious equality of the Negro and his right to access the church and the sacraments." But that was the extent Toolen was willing to go in the cause of racial justice. He often "warned against social equality which led to 
nothing but trouble."12 On the other hand, when the issue of the morality of segregation was raised, his standard response was to deny that segregation existed at all in his diocese.

Keeping in mind the difficulties of balancing the competing requirements of Catholic doctrine and Southern custom, it was no accident then that Toolen sought outside help for work among African Americans. Few Southern men could be found who were willing to enter the priesthood, and of those, few could be convinced to work among blacks. The Irish priests Toolen recruited were also reluctant to work among blacks as they quickly adopted the social customs and attitudes of Southern whites. So the task of bringing the faith to the large numbers of Southern blacks Toolen hoped to reach was left in the hands of "Yankee" priests — from such orders as the Josephites, Vincentians, Passionists and Edmundites. Like the men and women they sought to evangelize, these men took upon themselves a double minority status in the South, as Catholic and, in the most cutting pejorative reserved for whites, "nigger-lover." It was in this milieu that the Society of St. Edmund planned to set up a small mission in Alabama.

The Society of St. Edmund is a small religious order headquartered in Vermont. Father Jean-Baptiste Muard had founded the society in France in

12 Moore, Catholics in the Modern South,152. Moore cites Foley's unpublished memoirs "In the Shadow of the White Camellia's" of which there are two versions. One is located in the archives at Spring Hill College, Mobile, AL and the other is in the possession of Miss Joan Sage of Mobile. Each version is slightly different. All Foley quotations are from the Spring Hill version, 210-213. 
1843.13 The order originally functioned as "auxiliary priests" and conducted parish missions in and around Burgundy. However, in 1891 the chapter decided to establish a mission in Canada in the hope of avoiding the social and political turmoil that plagued France at the turn of the century. Upon their arrival in Quebec, two of the priests were instructed to contact Bishop Louis de Goesbriand of Burlington, Vermont, who was in desperate need of Frenchspeaking clergy for his diocese. Within a few years, the Edmundites were administering parishes in Vermont at Keeler's Bay and Swanton. ${ }^{14}$ In 1902 the order purchased a small farm in Winooski Park for a novitiate. Two years later this was transformed into the first Catholic college in the diocese. In 1913 the school was incorporated as St. Michael's College. ${ }^{15}$

The Reverend Victor Nicolle, S.S.E., Superior General of the Society from 1930-1946, gave the following reason why the Edmundites decided to establish a mission among African Americans in the South:

First, we needed more diversified activities for our members than we had then Second, I thought that it was good spiritually for the community to have to do some work that would demand a greater measure of sacrifice than what we had. There was also the reason that about this time the Holy

13 On September 29, 1852, the auxiliary priests became constitutionally known as the "Society of the fathers and the Brothers of Saint Edmund, Oblates of the Sacred Heart of Jesus and the Immaculate Heart of Mary." The Chapter in 1970 adopted the title, "Society of Saint Edmund," in the interest of simplicity and as a result of custom. They are commonly referred to as 'Edmundites.' The order was awarded pontifical status by Pius IX in the spring of 1876. A Brief History of the Edmundites. (Winooski, Society of St. Edmund Web Page URL: http://sse.org/history.htm).

14 The mission at Keeler's Bay was founded in 1891 and Swanton was founded in1895. Brief History. 15 Ibid. 
See urged religious communities to interest themselves more in the work of conversion of the Colored. ${ }^{16}$

In 1926 Pope Pius XI's Rerum Ecclesiae addressed the state of Catholic missions. The Pope, citing Benedict XV's 1919 encyclical Maximum lliud, was concerned that the recently ended World War would have lasting negative consequences for both foreign and domestic missions. ${ }^{17}$ The Pope stressed the importance of evangelization, declaring:

It seems to Us that two special objectives ought to be aimed at in all missionary work, both of which are not only timely but necessary and closely connected with each other; namely, that a much larger number than heretofore of missionaries, well trained in the different fields of knowledge, be sent into the vast regions which are still deprived of the civilizing influence of the Christian religion; and secondly, that the faithful be brought to understand with what zeal, constancy in prayer, and with what generosity they too must cooperate in a work which is so holy and fruitful. ${ }^{18}$

However, the opportunity for mission work outside Vermont did not present itself for a number of years. It was the Order's contact with a Passionist priest some ten years after the papal encyclical that inspired the Society to establish a mission in Alabama.

Father Stephen Sweeney, C.P, had preached at the Society's annual retreat of 1936. Sweeney worked in Alabama and was familiar with the need of Bishop Thomas J. Toolen of Mobile for clergy to work in what was then called the Colored Apostolate. Superior General Nicolle, with a letter of introduction from

16 Joseph Couture, Twelve Years in the Southern Missions, 8. Sisters of St. Joseph Archives (SSJA) Selma Collection Box13-Folder 1-1/"History- Establishment of Mission." See also Cyprian Davis, The History of Black Catholics in the United States, (New York, Crossroads, 1993).

17 Rerum Ecclesiae. Pope Pius XI. 1926. 9.

18 Ibid, 3. 
Father Sweeney, met with Toolen in December of 1936 to discuss the details of the Society establishing a mission there. A month later, Nicolle accepted Toolen's offer to work in the diocese. During their initial meeting, Toolen had also mentioned that there was some land in Selma that the society might use for the mission, and Nicolle inquired about making the necessary arrangements to transfer the property. Nicolle was also concerned that the missionaries might be isolated in the city, and suggested to the bishop that he might eventually assign three priests to the mission. ${ }^{19}$ In the meantime, Nicolle chose two priests for the task.

Nicolle assigned Father Francis Casey, S.S.E., to lead the new mission. Casey had been a district manager for Travelers Insurance Company in Hartford, Connecticut, but in 1927 had returned to his hometown of Dorchester, Massachusetts, with the hope of entering religious life. ${ }^{20}$ Born into a devoted Catholic family in 1901, he had attended Boston Public Latin, and had for some time considered entered the priesthood. ${ }^{21}$ However, he was having difficulty finding a community he wished to join. He consulted his parish priest, Father David Murphy, who pulled open his desk drawer and said, "I got this in the mail the other day. Look them up." Murphy then handed Casey a brochure describing the Society of St. Edmund. Murphy and Casey visited the school, and spoke with Father Charles Dodge, S.S.E. Dodge met the two men wearing his cassock over

\footnotetext{
19 Nicolle Letter to Thomas J. Toolen. January 25, 1937. ADMA Box 1937 File: "T"

20 "Rev. Francis Casey, S.S.E. Buried in Selma" Catholic Week. n.d. SSJA Selma Collection, Box G 13-1-1/"Funeral- Father Casey."
} 
his overalls. The no-nonsense, practical spirit of the community intrigued Casey. He exclaimed to Father Murphy on the ride home, "This is it, I think, Father. Did you see the pants that priest had on? A pair of overalls. A gang that can't even have pants sure is poor." 22 Casey was accepted into the order in 1930 , but as his education had been in business, he was forced to continue his studies. He completed his theological studies at Putney, Vermont, and was ordained in 1936.

The priest assigned to assist Casey was Father John Paro, S.S.E. The two men had been classmates at St. Michael's and had taken similar paths into the priesthood. Upon graduating from high school, Paro worked as a traveling salesman. During a friendly bridge game with his parish priest, Paro first considered attending college. His priest suggested that he attend St. Michael's. During his sophomore year, Paro decided to enter the novitiate of the Society, and on September 1, 1930 he took his first vows. He was ordained the same year as Casey. ${ }^{23}$

Casey’s first task was to raise money for the project. He secured $\$ 5,000$ from Father Richard Cushing of the Propagation of the Faith Office in Boston. ${ }^{24}$

\footnotetext{
21 lbid.

22 Casey is quoted in Francis Egan, "An Old Friend of Father Casey Writes," Your Edmundite Missions Newsletter, June 1967, 10.

23“ A True Pioneer of the South," Your Edmundite Missions Newsletter, January 1978, 2. Paro was first assigned to teach in the Society's Juniorate, but in 1937 he was asked by Nicolle to assist Casey.

24 Egan, "An Old Friend," 11. See also Francis Casey Letter to Thomas Toolen. October 25, 1937. ADMA Box 1937, File: "C." Note: The Donor was Miss Catherine G. O'Brien who requested that the money be used for a chapel in memory of her sisters and asked that it be dedicated to St. Elizabeth of Portugal Couture, Twelve Years, 7-8. records: ". . . the Stipulations
} 
With the money from Cushing, the two priests began the long trip to Alabama in a new Pontiac recently donated by the Burlington Merchants Association. ${ }^{25}$

In 1937 the two priests loaded up their car and began the long drive from Winooski, Vermont to Selma, Alabama. The two men were charged with the task of establishing a mission within the African American community of the small Southern town. Neither man had ever done mission work, nor did they have any experience of working among blacks in the Jim Crow South. Nothing could have prepared them for the obstacles and challenges they would confront. Leaving in late June, the two men stopped along the way to visit friends and solicit donations of money and supplies for their mission. ${ }^{26}$ They arrived in Selma, Alabama, on July 6, 1937 in a car filled with hammers, nails, and saws. With a small amount of money, donated supplies and a great deal of faith, the two drove southward into the heart of Alabama's Black Belt. ${ }^{27}$

The city of Selma was founded in 1820 at Moore's Bluff, overlooking the Alabama River in Dallas County. Located in the heart of Alabama's Black Belt, Dallas County quickly became the richest cotton-producing region in the state. In order to produce the cotton, large numbers of slaves were imported into Selma, and the city became an important regional slave market. Between 1840 and

\footnotetext{
are that the finished chapel be a memorial to a single donor, and that the donor be present at the time of the Blessing (if possible)." Cushing was later Archbishop of Boston and a Cardinal.

25 Couture, Twelve Years, 1

26 "A True Pioneer," 2. The author notes that the two men stopped at Catholic University in Washington D.C. (c. early July, 1937).

27 Note the term 'Black Belt' refers to the rich alluvial soil of the area and not the large African American population that was brought into the area in order to work the land.
} 
1850 the amount of cotton shipped down the Alabama River doubled, and in the next decade that number doubled again. The city soon established itself as the economic hub of west central Alabama. ${ }^{28}$ During the Civil War, the city's railroad and river access made it the logical choice for a Confederate arsenal and the city became a key supplier of arms for the Confederate Army. The Confederate naval yard was relocated to Selma following the fall of New Orleans to Union forces in April of 1862 . On April 2, 1865, Union forces attacked the city. Out-manned, the Confederate forces were soon overwhelmed and the city was captured.

Following the war, large numbers of freedmen moved into the city seeking jobs, schools and churches. The city's black population quickly jumped from 1,386 in 1860 to 3,660 in 1865.29 The first black public school, Burrell Academy, was founded in 1869 with teachers and funding from the American Missionary Association. The black members of the First Baptist Church left the church in 1866 and established their own congregation. Black Methodists also split with their white counterparts in the Methodist Episcopal Church South, and with help from missionaries from the African Methodist Episcopal Church and African Methodist Episcopal Zion established their own congregations.

In 1865 Selma became the Dallas County seat, but the war had done grievous harm to the city and its economy. ${ }^{30}$ The city's brief reign as an industrial

28 Alston Fitts, Selma: Queen City of the Blackbelt. (Selma: Clairmont Press, 1989), 1-10, 23, 50. 29 Ibid, 70. 30 Ibid, 66. 
center was soon overshadowed by Birmingham, although the railroads and cotton mills still made Selma an important regional economic center. By 1868 the city's black leadership was well established and produced Dallas County's first black congressman, judge and state senator. ${ }^{31}$ In the mid 1870 s a number of black colleges were founded. The Reformed Presbyterian Church founded Knox Academy in 1874. In 1878 the Baptists founded Selma University, and in 1889 the African Methodist Episcopal Church founded Payne Institute. ${ }^{32}$ However, the gains made during Reconstruction were short-lived. The Compromise of 1877 placed control of the South back in the hands of its white planters.

Upon their arrival, Casey and Paro found a city of some 20,000 people, roughly half of whom were African American. The black community was struggling in 1937 with the Depression and with Jim Crow. Selma had no local black-owned newspaper and the illiteracy rate was 50\%. Selma's black professional class consisted of three dentists, two doctors, over a hundred teachers, two principals, a number of ministers and the presidents of Concordia College and Selma University - people whose positions did not allow them a great deal of protection from white authority. ${ }^{33}$ The jobs of the teachers, the

\footnotetext{
31 Ibid. Benjamin S. Turner was elected to the House of Representatives in 1870. Roderick B. Thomas was elected the first black judge in Alabama history in 1874 and Jeremiah Harrelson was elected the first black state senator in 1868.

32 Ibid, 91.

${ }^{33}$ Chestnut, Black in Selma. 92. Concordia College was founded by Dr. Rosa Young in 1922 in order to train Lutheran missionaries for work among blacks in Alabama. Selma University was
} 
largest professional group, were entirely in the hands of the white school

board. ${ }^{34}$ There were no black lawyers in town. Only a small number of African American businesses, mostly restaurants and bars in an area called "The Drag," operated in Selma. ${ }^{35}$ Selma did have a number of textile mills, but the work was temporary, the conditions were dangerous and the wages were low. ${ }^{36}$ The 1940 census recorded that only ten percent of black Selmians were employed in whitecollar jobs and seventy five percent of black women worked as domestic servants. ${ }^{37}$ While many blacks moved off farms and into the city, agriculture dominated the economy. Few if any African Americans could vote, and only one local organization struggled to address that issue. The city was heavily Protestant.

The house owned by the diocese and promised to the Edmundites was located at 1415 Broad Street, the main thoroughfare of town. Archbishop Toolen agreed to transfer ownership of the property to the Society of St. Edmund so long as they remained in the diocese. ${ }^{38}$ With the money contributed by Cushing,

founded in 1878 as the Alabama Baptist Normal and Theological School to train blacks to become ministers and teachers.

34 Ibid, 119.

35 Chestnut, Black in Selma, 10-11.

36 Robert Scott Hereford, "A Study of Selma and Dallas County, Alabama, 1930-1970," (M.A. Thesis: University of Georgia, 1989), 37-38.

37 United States Department of Commerce, Sixteenth Census of the United States: 1940, Population, Vol. II, (Washington: United States Government Printing Office, 1942), Characteristics of the Population, 323. Cited in Hereford, "A Study of Selma and Dallas County," 39, 41.

38 Francis Casey Letter to Thomas J. Toolen. Casey wrote; "The point at issue we both agree on, i.e. what happens when you and I are gone. Both the diocese and the Community should be properly protected. This can be accomplished by a contract as well as by a deed, in fact better, for a deed would have to be supplemented by a contract in any case. If you will, therefore, draw 
Casey purchased the nearby Hasselvander house at 1423 Broad Street. The large plot of land was a motley collection of dilapidated structures-a house, the remains of an old gas station and some smaller outbuildings. Most recently, the house had served as a brothel. ${ }^{39}$ Since all of the buildings needed serious repair, the fathers rented an apartment from Claughton Johnson a few blocks down on Broad Street in the white section of town. They took their meals at the local white Catholic Church. 40 The fathers tore down all but the frame of the house at 1423, and with the help of a young African American teenager, W.D. "Deb" Herman, set about rebuilding. ${ }^{41}$

The reception of the priests by Selmians, white and black, was muted. The Mission history recalls, "Their reception in this beautiful little Southern town was not exactly cordial. There were few Catholics and the good Southerners were very suspicious of Yankee priests working with the Colored people."42 The "Yankee priests" not only posed a potential threat to the white power structure of Selma, but also were directly competing with Selma's Protestant African American religious institutions for parishioners. Anti-Catholic sentiment was rampant among both whites and blacks. But the Edmundites were not the first Catholic missionaries in Selma.

up the contract turning over the property to the Community as long as they remain in the diocese I shall see it properly signed."

39 Couture, Twelve Years, 2.

40 "Your Missions 15th Anniversary," Your Edmundite Newsletter August 1952,10.

41 Couture, Twelve Years, 2. Couture cites "Deb, a colored boy "as the helper.

42 Ibid, 1. 
Irish workers who came to the city in the 1860 s to work in the war industries formed Selma's first Catholic Church. The Church of the Assumption was built in 1869 with stones recovered from the old arsenal. ${ }^{43}$ The Society of Jesus made Selma its headquarters for central Alabama in 1880. Prior to that date, a single Jesuit missionary attempted to minister to the Catholics scattered among the eighteen surrounding counties. The only other Catholic church was in Demopolis, fifty miles to the west. ${ }^{44}$ The Masonic Hall in nearby Cahawba was moved to the city and reopened as St. Andrew's Hall, a Catholic boys' school. The Religious of the Sacred Heart arrived in 1884 to administer a girls' school, Sacred Heart Academy. In 1888 the Sisters of Mercy took over operation of the school. The Jesuits maintained the Selma mission until 1931, when it was returned to the Diocese of Mobile. ${ }^{45}$ Father McCormack, pastor of Assumption in 1937, offered some advice to the fathers. He cautioned the priests against working too hard in the Alabama heat. "You fellows aren't used to this climate. Many a priest has made the same mistake you boys are making. You can't stand the pace. Dixie will be here long after you and I are gone."46

Like their counterparts throughout the South, Selma's white Catholics masked their religious difference with a firm commitment to segregation.

43 Fitts, Selma: Queen City, 73.

44 "Assumption History-- Jesuit Manuscript," SSJA Selma Collection Box G13 File 14/Assumption. Manuscript from a Jesuit father's (name unknown) history of the Selma mission. From the Collection of Miss Clementime Lambrecht. The work was transcribed by Florence Lambrecht Swanson.

45 Fitts, Selma: Queen City, 94.

46 Casey Letter to Toolen. 2. 
Assumption had no black parishioners. One parishioner of Assumption refused to believe that Catholic priests were in Selma to serve among African Americans. She was convinced that the priests must be Episcopalians, and was shocked when the priests appeared at Assumption to offer Mass the following Sunday. 47

Unsure of the priests' motives and wary of competition from Catholics, the reactions of Selma's African American ministers ranged from indifference to outright hostility. The response of the Rev. D.V. Jemison, pastor of Tabernacle Baptist, chair of Selma University and head of the National Baptist Convention U.S.A., illustrates the mixed feelings of African American Protestant ministers toward the missionaries. Jemison, whose church was located next to the former gas station/brothel, was asked how he liked his new neighbors. He was reported to have said, "Those Priests? Well, I don't know, but I suspect they're probably a little better than the last white trash we had in there." 48 Within a month of the priests' arrival, Jemison began building a twelve-foot fence between his church and the fathers' land. Another unidentified African American minister called on the fathers to wish them well. His comment is indicative of the lack of understanding most Protestants had of Catholics:

Father Casey mentioned that they had quite a job ahead of them. His answer was, "Of course you have a job and it is only the Catholic Church today that will take a hard job." Before leaving he asked: "Where is you all going to build your Cathedral?"49

\footnotetext{
47 The Selma Missions. Rochester.

48 Couture, Twelve Years, 5.

49 lbid, 5.
} 
The Rev. Claude C. Brown, pastor of the Black Reformed Presbyterian Church, was reported to have attacked the Catholics as Communists. 50 "The Catholic Church would do well to mind its own business, keep out of the South, and let the Negro alone," Brown was quoted as saying. ${ }^{51}$ However, unlike their white counterparts, Selma's African American clergy were, for the most part, willing to wait and see what the priests had to offer the black community.

In general, Selma's white Protestants were very suspicious of the priests' motives. One woman approached Casey and Paro as they worked on the house, hoping to get to the bottom of the rumors. Casey recounted:

We were in our undershirts and covered with dirt. "Are you working here?" she asked. "Yes ma'm," I answered. "Well," she said, "perhaps you can tell me what is going on here. I have heard that some of those Catholic priests are coming here and I just hope there is no truth to that." '"Well, Lady." I answered, "you are talking to a Catholic priest now and there is another one over there," pointing to Father Paro who was also incognito. I wish you could have seen the little lady dash out. 52

The police questioned the two priests to ascertain their reasons for being in town. The officers told Casey they were investigating reports of "a couple of bogus priests who were going to seduce the Negroes and swindle the whites." 53 In addition to this cool reception, other problems plagued the priests. Their plot of land was located in a poor black section of town, and the abundance of building supplies stored on the lot made it an easy target for thieves. Casey

50 J.L. Chestnut and Julia Cass, Black In Selma: The The Uncommon Life of J.L. Chestnut, Jr. (Politics and Power in a Small Town), (New York: Farrar, Strauss and Giroux, 1990), 41.

51 Couture, Twelve Years, 5. See also Chestnut, Black in Selma, 41, 184-5.

52 Couture, Twelve Years, 4. 
purchased a watchdog in order to combat the constant break-ins. He wrote to a fellow priest:

Captain, a fine greyhound, took us out of bed three times last night. There is much loose lumber around and the car is in the alleyway. Whoever it was, was scared away before anything was taken. The rates on burglar insurance are high in this district, and I do not feel that we can afford it. Hence, we have more appreciation for the efforts of the dog.

Despite these troubling encounters, Casey and Paro concentrated on rebuilding the Hasselvander house and constructing a temporary chapel. Within a few months the house was sufficiently finished to allow the priests to move in on September 23, $1937 . .^{54}$ The house consisted of two bedrooms, a temporary chapel, an instruction room, kitchen and a screened-porch that was used as a dining room.

As yet, Casey and Paro had made no contacts among the black community since their arrival. Casey wrote to his superiors in Vermont:

While we have found but two practical Negro Catholics here, we have ascertained there is a little settlement of them who are waiting for a church. They will not go to the church for the whites. They have already started coming to the rooms where we are living, and since this is in the white section, we can do nothing but put them off. If we move into our own house in the Negro section, we can deal with them. We can't here."55

The two priests began constructing the chapel and establishing a congregation. In October Nicolle sent Father Joseph Walsh, S.S.E. to help with the nascent mission. When Walsh arrived, the three priests took out a map of the city, and

53 lbid.

54 Ibid, 4.

55 Ibid, 2-3, 9. 
divided the entire area into sections. ${ }^{56}$ The men then began canvassing African American neighborhoods looking for lapsed Catholics and potential converts. The mission began with two Catholics, "Deb" Herman and Becky McGuire, and grew quickly, as it expanded its work in the African American community. ${ }^{57}$ The three priests visited families in the African American community, especially the elderly, sick and shut-in. Soon the mission had a number of lapsed Catholics and aspiring converts attending Catechism classes and participating in regular masses. The fathers provided whatever aid they could to those in need, regardless of their church affiliation. Usually they supplied food, firewood or medicine. Almost immediately, all the resources of the mission were pressed into service; that spring, floods ravaged the town, and the mission provided space, blankets, food and medicine to families in the area. 58 Casey soon came to the conclusion that he needed more help in order to serve the needs of the African American community. He wrote to Archbishop Toolen in November of 1937, and mused:

One of my "day-dreams" is on me and your advice is much needed. The question of Sisters in Selma. Of course, from all external appearances they are somewhat remote, but I hesitate to wait too long to start lining them up. 59

Toolen contacted the Sisters of St. Joseph in Rochester, New York. The order, engaged primarily in teaching and nursing in Rochester, had been founded in

\footnotetext{
56 "A True Pioneer of the South," Society of St. Edmundite Newsletter, January 1978, 2.

57 The Selma Missions, 1-2. SSJA, Selma Collection. Box G13-1-1 File: "History-Establishment of Mission 8A."

58 Couture, Twelve Years, 9.
} 
$17^{\text {th }}$ century France as an active community whose members went out to "quarter the city," to assess the needs there, and to do "any work of which women are capable" to address the root causes of the suffering they found. The order came to Carondelet, Missouri in 1836 and spread throughout the United States and Canada. They arrived in Rochester in 1854. They established Nazareth College in Rochester in 1924, ran St. Joseph's Hospital in Elmira, New York, and administered approximately 100 schools in the diocese. ${ }^{60}$

White Southern Catholic Sisters did not do mission work among African Americans and bishops were forced to recruit outside of the South. One of the nuns eventually assigned to the mission, Sisters Mary Paul Geck, S.S.J., explained:

When Archbishop Toolen wanted to establish a school for black children, he knew he would have to get Sisters from the North. He couldn't get Sisters from the South, because they considered themselves Southern first and Catholic second. I got that right from one of the Sisters themselves."61

White women religious from all over the United States came South to work in African American communities, setting up schools and hospitals. Sisters Rose Miriam Smith, Mother Superior of the Sisters of St. Joseph, Father Casey and Reverend John Randall, Director of the Society for the Propagation of the Faith for the diocese of Rochester, discussed the possibility of the order sending some Sisters to the nascent mission. Casey was forthright in admitting that he had no

59 Franics Casey Letter to Thomas J. Toolen. November 2, 1937. ADMA Box 1937 File "C."

60 For an early history of the congregation see Sisters of St. Joseph of Rochester, (Sisters of St. Joseph: Rochester, 1950). The author is listed only as "A Sisters of St. Jospeh."

61 Interview with Mary Paul Geck by author (March 2, 2001). 
money to pay the Sisters. ${ }^{62}$ In spite of the enormous difficulties, Reverend Mother Smith announced in June 1940 that five nuns would be appointed in August to serve in Selma.

On August 27, 1940, Sisters Francis Marie Kehoe, Catherine Charlotte Hyland, Anastasia McCormick, Francis de Sales Murphy and Mary Ellen Dundon were chosen for assignment in Selma.63 All were young, and few had ever traveled outside the diocese of Rochester. The Sisters arrived by train in Montgomery in September 1940, and were met at the depot by Father Casey. They were taken to Mass at St. Margaret's in Montgomery, and after a short tour of the State Capitol they were driven to Selma. In a report to the Motherhouse in Rochester, one of the Sisters recounted their initial impressions of the mission:

Our first Sunday in Selma and how shall I describe our sensation as we found ourselves the only white people in a congregation of about eighty. The altar boys too were black and non-Catholics. They attend Mass and instructions regularly but they will not be baptized until they are sixteen unless their parents are received into the Church before that. About fifteen people received Holy Communion, one of them a First Communicant.

We have just had Benediction in our little Chapel (Feast of the Holy Rosary). The Extension Society, through the efforts of Rochester chapter, Order of Martha, sent us a box of beautiful new vestments and a generous supply of altar linens. Father wore the cope and Benediction veil tonight for the first time. So you can see we are all strongly bound together by the ties material as well as spiritual. 64

\footnotetext{
62 Francis Marie Kehoe Lecture. August 11, 1977. SSJA, Selma Collection: Audio Recording. 63 "Chronicle of the Selma Mission," 1. SSJA Selma Collection: Box G13-1-1 File: "HistoryEstablishment of Mission 8"

64 "Selma News- First Report" (1940), 1. SSJA Selma Collection: Box G13-1-1 File: "HistoryEstablishment of Mission 8"
} 
The Sisters moved into the rectory while Casey, Paro and Walsh moved into the parish hall, the front of which served as Casey's office and the rear as living quarters for the priests. Casey then purchased a small shack on an adjacent piece of property, which they began renovating to serve as the new rectory. 65

Like their male counterparts, the Sisters were ostracized by the white community, Protestant and Catholic, for their identification with blacks. The Sisters prayed, evangelized, worked and spent their free time in the black community. The trust and loyalty that the Sisters engendered was the result of their tireless efforts on behalf of their parishioners and the community. One Sisters recalled:

In the course of a catechism lesson not long ago, one of the Sisters was speaking of moral goodness to some of the smaller children of this colored mission. In the course of her remarks Sisters said that it didn't matter whether one was colored or white. The important thing was to be good. If God wanted one to be a colored person, it was the same she said, for white people. Regardless of color, God wanted all people to be good. During this lecture one little girl intently watched Sisters and after the class was over and went to the Sisters and said, "Sisters, if you get much lighter folks are going to think you are a white lady."66

But it was Selmians themselves who made the clearest distinctions among between those who worked among whites and blacks. White Selmians referred to the Sisters of St. Joseph as the "black Sisters," while African American Catholics referred to them as "their" sisters. ${ }^{67}$

65 Sisters Kehoe Lecture.

66 Patricia Creighton, "What were you doing in Selma, Sisters?," (B.A. Thesis: State University of New York at Purchase, SUNY Purchase, 1988), 92.

67 Sisters Mary Paul Weaver interview by author (March 2, 2001) 
The Sisters' primary role in the mission was evangelical. They continued the practice of home visits and provided what help they could to Selma's African American families. The Chronicle of the Mission Convent recounts the early years:

During the first year the sisters set about visiting homes, assessing the needs of the elderly, the children, the sick; they gave religious instruction to women in their homes or at the mission; they brought the sick to doctors or cared for them in their own homes; they held recreational programs for young people each night and held rummage sales to involve people in helping each other. 68

Both the fathers and the Sisters were constantly struggling to provide for the practical, as well as the spiritual, needs of their parishioners, the mission and the African American community. The Sisters did not receive a salary and so were completely dependent upon themselves, the congregation, the fundraising activities of the mission, and friends, to provide for their needs. Sisters Marie Albert Alderman, S.S.J., noted that, "We were often helped by our northern communities. They sent us clothes and gifts and through their generosity we were able to have a clothes room for continuous availability to the poor."69 Taking in donations of clothing from all across the country, but particularly Rochester and Winooski, the mission sold clothes and during the holiday seasons they sold gifts and toys at very reduced prices in what was known as the Clothes Room. The small amount of money that was charged was reinvested into the mission and helped to defray the mission's costs for other programs.

68 "Interview with Dr. Isabel Dumont and Joan Mulder, "Your Edmundite Missions Newsletter. (Easter 1966), 10. 
Soon the Sisters set about planning an elementary school. It was obvious that the community desperately needed more educational facilities. In the spring of 1940 a kindergarten opened, and by the next fall, the first grade was begun. Housed in the parish hall, the school was open to all. A new grade was added each year through the eighth grade. Facilities were spartan, with tables and chairs built by Casey. The school provided a lunch for the children, often the only meal they would have each day. A federal government program funded half the cost of the program; the mission paid for the other half. ${ }^{70}$ In 1941 a small house was purchased for the school. As there was no library for African Americans in the city, the mission established one in 1948 with books donated by priests, Sisters and friends of the mission. The library had 4,617 volumes (500 children's books) and 427 borrowers registered in the first year. ${ }^{71}$ Since the city did not provide transportation for black school children, the mission provided transportation with a donated school bus. In addition, the bus enabled parishioners who lived outside the city to attend Mass. ${ }^{72}$

By 1950 it was apparent that the small house the fathers had purchased for the school would not hold the growing number of students who wanted to attend. The schoolhouse was filled to capacity, and rooms in the parish hall were

69 lbid.

70 Sisters Kehoe Lecture.

71 Chronicles of the St. Elizabeth's Convent, 112.

72 Your Edmundite Newsletter (Easter, 1950), 2. 
pressed into service as classrooms. ${ }^{73}$ In 1951, with money raised from across the country, the mission began construction of a new state-of-the-art school that would house grades K-8 in one facility. The building was finished in December of 1952. Over three hundred students attended St. Elizabeth's school in its first year of operation. ${ }^{74}$ The old school house was then converted into space for the expanding library and as a home for a newly established Girls Club. ${ }^{75}$

While work on building the mission in Selma progressed, a number of new challenges were given to the Edmundites. In 1937 Toolen asked the priests for help in establishing a mission in the city of Anniston in the northeastern part of the state. By 1945 the small mission in Selma would become a Mother Mission House to eight missions in Alabama and a large mission in North Carolina, covering ten counties. ${ }^{76}$ Like the fathers in Selma, the missionaries built chapels, rectories and parish halls. They arranged for Sisters from northern dioceses to help them establish schools. The expansions necessitated more priests and money being sent South. They also necessitated a change in the organizational structure of the Selma mission. Casey, in addition to being pastor and superior

73 "St. Elizabeth's School," Your Edmundite Newsletter, (Christmas 1950), 2. SMCA, SSEP: Selma Collection: Your Edmundite Missions Newsletter.

74 "St. Elizabeth's School," Your Edmundite Newsletter. (1953), 6-7. SMCA, SSEP: Selma Collection: Your Edmundite Missions Newsletter.

75 lbid, 10.

76 The mission in Anniston was founded in 1937. The St. Rose of Lima Mission on Mon Luis Island on Mobile Bay and Belle Fontaine were founded in 1939. In 1940 the Diocese of Raleigh requested the fathers open a mission in Elizabeth City, North Carolina. Also in 1940 the fathers founded a mission in Heron Bay, Alabama. In 1941 the fathers took over the Our Lady of 
of the St. Elizabeth's Mission, was given the title Director of Southern Missions. He was responsible for administering the various missions, coordinating the constant fundraising, and producing the newsletter. ${ }^{77}$

Meanwhile, work in Selma continued. One of the many problems that the Mission sought to address was that of finding adequate housing for the aged. The fathers and Sisters often found elderly blacks living in appalling conditions. Unable to work, without family, and without access to basic government social services, these men and women were left to fend for themselves in shanties throughout Selma. Casey purchased a small house near the mission and renovated it for use as a retirement home. Sisters Kehoe recalled:

There was no place for them to go so the fathers bought this house and they called it Holy Infant Inn. There was a hall down the center. There was one side for the men and the other for the women, a bathroom at the end, and a kitchen The price to get in was to have nothing. ${ }^{78}$

On Christmas Eve in 1943, the Holy Infant Inn opened with six residents. ${ }^{79}$

Casey had recognized the need for expanded medical care for the aged and homeless. The Holy Infant Inn provided free care for aged blacks on a nonsectarian basis. By 1945 eighteen men and women were living in a house that was meant to house twelve. ${ }^{80}$ Eventually, the small house was unable to

Lourdes Parish in Mobile. The next year a mission station was opened at Fowl River. In 1943 Archbishop Toolen assigned the fathers St. Agnes Parish.

77 “Edmundite Mission Territories- 1937-1957," Your Edmundite Newsletter, (October 1957), 8-9.

78 Sisters Kehoe Lecture.

79 Chronicle of Selma Mission, 2. SSJA Selma Collection: Box G13-1-1 File: "HistoryEstablishment of Mission 8."

80 "Old Folks Home," Your Edmundite Newsletter (1956). S. Mission. Selma, Society of St. Edmund,12. 
accommodate the growing number of residents and the fathers screened in the front porch in order to make more room. .1

In 1940 Casey had wondered about the possibility of opening a medical clinic, but had opted against it "until such time as conditions in the town were more favorable and perhaps for a play on the city helping to finance it." 82 Casey and the Society were reluctant to overextend the limited resources of the mission. His decision not to open a facility, however, did not deter some of the Sisters from soliciting donations of medical supplies in the North to help ameliorate the lack of proper medical care in the city. ${ }^{83}$ However, four years later, recognizing the desperate need to provide improved medical care to Selma's black community, the Society looked into purchasing a small two-story wooden building from the Baptist Hospital Association. ${ }^{84}$ Assistant pastor Norman Lambert, S.S.E., wrote to Reverend Mother Smith to ask for nursing Sisters who could work in the hospital:

My interest with the colored is primarily spiritual. On the other hand there are corporal works of mercy, and God knows these people need care, it seems in His wisdom He has decided that the exercise of corporal works of mercy directly affect all things spiritual, and hence, for the spiritual and material good of the colored, I am most anxious to go ahead. ${ }^{85}$

$81 \mathrm{lbid}, 2$.

82 Casey Letter to Victor Nicolle. October 14, 1940. SMCA SSEP Selma Collection File:"Casey Correspondence."

83 lbid, 1.

84 "The History of Good Samaritan Hospital," Good Samaritan Newsletter Vol. 1, no. 1 (December 1964), 1. Author's collection.

85 Norman Lambert Letter to Rose Miriam. April 6, 1944. SSJA Box 13-1 File 2. 
At the time the city had three hospitals: Vaughn Memorial, Baptist, and King Memorial. All three were private; each had roughly 50-60 beds and none accepted African American patients.

Burwell Infirmary and Good Samaritan Hospital provided medical care for blacks. Burwell was originally a small infirmary with fourteen beds, which had been founded in 1907 by Dr. Burwell. Mr. and Mrs. [Minnie] Anderson came to work at Burwell in 1926 and now operated it. Mrs. Anderson served as a nurse and her husband as a lab technician. Eventually Burwell would have a small Xray room, first aid room, a five-bed children's charity ward, maternity ward with a small bassinet-nursery, a single incubator and a twenty-five-bed nursing home annex. ${ }^{86}$ It was at Burwell that the white doctors from Vaughn Memorial saw their black patients. A very small clinic, it could care for only a few patients at a time. Casey described the other clinic:

The second is ... located exactly two blocks from our property. Its start I do not know, but I do know that the doctors who own the Baptist Hospital bought it some time ago and use it for their patients. As far as the usual conception of a hospital goes it is nothing much either. It can comfortably handle perhaps thirty patients and constantly has in it between 40 and up to 50. It is a series of frame buildings added to the original, the latest addition including a small operating room. ${ }^{87}$

Doctors from King Memorial and Baptist saw their black patients at Good Samaritan.

${ }^{86}$ Hatch, M. (1965). Report on Burwell Infirmary Selma, Alabama. Selma, Selma Project: 1-5, 1. Burwell was the grandfather of Good Samaritan physician William Dinkins.

87 Lambert Letter to Miriam. April 6, 1944. April 6, 1944. SSJA Box 13-1 File 2. 
The board of Baptist Hospital told Casey that the group had decided to sell Good Samaritan, even though it was making money. The group admitted it was unhappy with the condition of the facility, and they hoped that the fathers would be able to provide a better environment for both patients and doctors. Casey doubted that the hospital was doing well financially, and was extremely concerned about the expense such a project would entail. The lack of support among Selma's medical community made him especially wary. He confided to Reverend Mother Smith:

As you know for almost seven years all the attempts that we have made to secure the cooperation of the local medical profession in connection with some type of clinical work have met with not only a negative but a violently negative response. I have never neglected an opportunity to talk it over with the doctors whom I have come to know and yet had never gotten an affirmative hint, let alone a sign of cooperation. ${ }^{88}$

Casey discussed the possibility of purchasing the hospital with Archbishop Toolen. During these talks, Toolen told Casey about two young Catholic women, a doctor, and an X-ray and lab technician, who were interested in mission work. With the support of Toolen, the promise of a skeleton medical staff, and the promise of more Sisters of St. Joseph, Casey purchased Good Samaritan.

The fathers appealed to the War Production Board office in Birmingham for authority to renovate the facilities. The mayor of Selma and the administrator of Selma Baptist Hospital both sent letters to the Board in support of Casey's application. The War Production Board approved the alterations and additions at 
a cost not to exceed $\$ 7,000.89$ In the fall of 1944 , Sisters Louis Bertrand,

S.S.J., came to Selma as the first administrator of Good Samaritan Hospital along with Sisters Anastasia McCormick, Francis Xavier Dailor and Uriel Vernetti.90 The medical staff was racially integrated with two African American doctors: Dr. Ed Maddox and Dr. William Dinkens. ${ }^{91}$ It was the only hospital in Dallas County that treated African Americans.

Despite the assurances of the Baptist Hospital board to the contrary, the facility was in appalling condition. The building and equipment were filthy. Upon assuming control of the hospital, the Sisters began to clean out the rooms. Sisters Anastasia rounded up some out-of-work men on a nearby corner. In exchange for a set of clothes from the Clothes Room, they agreed to help the Sisters clean the hospital. All of the patients were taken out of the building, and the workers removed all of the equipment from the building. The mattresses were burned, the bed frames and equipment were sprayed with ammonia and the rooms were scrubbed and painted. Only then were patients returned to their wards. ${ }^{92}$

The two white laywomen Toolen had mentioned to Casey were Dr. Isabel S. Dumont and Miss Joan Mulder. Both women immigrated to the United States

88 Ibid.

89 "The History of Good Samaritan Hospital," Good Samaritan Newsletter Vol. 1, no. 1 (December 1964), 1. Author's collection. The Mayor at the time was Mr. P.T. Burns and the Administrator of the Baptist Hospital was Mr. W.H. Slaughter.

90 Chronicle of Selma Mission, 3.

91 Fitts, Selma: Queen City, 20. See also Chestnut, Black in Selma, 140.

92 Sisters Kehoe Lecture. 
to pursue their education. They met at Trinity College in Philadelphia and discussed their mutual desire to become missionaries in Africa. However, World War II prevented them from going. Answering an advertisement in the Journal of the American Medical Association, they joined the staff of St. Vincent's Hospital in Birmingham, Alabama, in 1943 where Dumont worked in the Obstetrics Ward and Mulder as a lab technician. Archbishop Toolen told the women about the work of Father Casey was doing in Selma. The Archbishop proposed that the two women join the staff of the new hospital. The two arrived in Selma on September 8, 1944. They would spend the rest of their lives providing care for Selma's black community. Over the years, the two women adopted a number of orphans whom they raised as their own. An accomplished artist, Mulder also established the Canterbury Arts Guild where she created liturgical art for the mission and taught arts and crafts to local black youths. ${ }^{93}$

In 1946 Father Casey was reassigned from the Selma Mission. Nine years of constant work had taken its toll on the Edmundite, and his health was failing. Father Norman Lambert, S.S.E., was assigned to replace Casey as

93 "The Citizens of Selma-Dallas County Present a Tribute to Dr. Isabel S. Dumont, M.D. and Miss Joan Mulder, Medical Associate," (November 3, 1974), 6-7. SSJA Box G13-1-1 File: "Celebration-Events 1." Dumont was born in Cologne, Germany, and had come to the U.S. in 1929 to attend St. Catherine's College in St. Paul, Minnesota, on an exchange scholarship. She received her B.S. from the University of Minnesota, her M.D. from Women's Medical College in Philadelphia and did her internship and some additional work in surgery at St. Mary's Hospital in Philadelphia. Mulder was born in Deventer, Holland. She graduated from Trinity College in Washington, D.C., with a degree in biology and did graduate studies in chemistry and biology. Pope John XXIII awarded Doctor Dumont and Joan Mulder the Papal "Pro Ecclesia et Pontifice" medal in 1961, and St. Michael's College conferred Honorary Doctorate Law Degrees upon them in 1966. In 1972, Dr. Dumont was cited as a Charter Fellow in the American Association of Family Physicians. 
superior and as Director of Southern Missions. One of the first issues that Lambert had to address was the growing tension between the Sisters and the fathers in regard to each group's role in the expanding mission. In September 1946, Sisters Vincentine Broderick, S.S.J., was appointed the new Superior of the Convent in Selma. Her traveling companion, Sisters Helene Garvin, S.S.J., spoke with Father Lambert about the difficulties the Sisters were having meeting all of the demands placed upon them by the school, hospital, Clothes Room, library, and evangelical work. Lambert wrote to Rochester and assured Rev. Mother Smith that the problems would be addressed, so that the Sisters would not feel overworked. The management of the Clothes Room was assigned to the fathers, the Sisters were advised not to do any more home visits or catechetical work, and a confessor other than the fathers was assigned to them by Archbishop Toolen. 94

From 1943-1947 the Sisters and staff worked in the old rambling building. According to Sisters Barbara Lum the building had open wires and holes in the floor where one could see through to the ground. She recalled that the place passed inspection only due to the good graces of the investigator and the assurances of the staff that a new hospital was being planned. ${ }^{95}$ In 1947 a 78bed two-story brick hospital was constructed adjacent to the original wood frame

94 Norman Lambert Letter to Rose Miriam. December 4, 1946. SSJA Box 13-1 File 2.

95 Sisters Barbara Lum Interview by Author (March 2, 2001) Note: Sisters Lum was known as Sisters Eleanor while she was in Selma, and following Vatican II reverted to her given name. 
structure. ${ }^{96}$ Archbishop Toolen dedicated the new hospital building on

December 2, 1947. In his remarks he:

thanked the fathers of St. Edmund, the Sisters of St. Joseph and all who made this day possible. He encouraged all white and colored to work together to solve the great problems existing in the South between white and colored. He condemned outside agitators who do not understand conditions of the South. ${ }^{97}$ The residents of the Holy Infant Inn were moved into space in the old building, and the Holy Infant Inn was converted into the new home for the parish boys' club.

In 1950 the Sisters inaugurated a Training School for Practical Nurses at Good Samaritan, the only such school for African Americans in Alabama. Seven years later the hospital was expanded again. The small frame building that housed the original hospital was razed and a new three-story brick building with modern operating room and delivery rooms, x-ray rooms and labs, kitchen and laundry facilities, and dining rooms was built. In addition, classrooms for the nursing school and a new wing for the nursing home were added. 98 Beginning with a handful of employees in 1944, the staff of the hospital reached 110 full-time employees by 1964, making it one of the city's largest employers. ${ }^{99}$

Two years after the fathers purchased the hospital, Father Nelson Ziter S.S.E. arrived in Selma to serve as assistant pastor. Ziter founded the Don

96 Your Edmundite Newsletter (Christmas 1946), 13.

97 "Dedication of Good Samaritan" Your Edmundite Newsletter (December, 1947), 3.

98 "Future Hopes for Your Good Samaritan Hospital," Your Edmundite Newsletter (Easter 1957), 8 and "Our Hope Our Dream Third Unit of Your Good Samaritan Hospital," Your Edmundite Newsletter" (October 1957), 6-7.

99 Joseph T. Smitherman, "Letter from the Mayor," Good Samaritan Newsletter Vol. 1, no. 1 (December 1964), 1. Author's collection. 
Bosco Boys Club (DBBC). 100 Named for Saint Giovanni Melchior Bosco, the club was the only center for black youth in the city. Pool, basketball, and pingpong were among the many activities that were available at the DBBC. Within three years, the club had 200 members ranging in age from 12 to 16 . It was an important source of converts for the mission. In a letter to Monsignor John Randall, the Sisters described the DBBC:

The clubs recently have been improved to the amount of $\$ 1500$. Showers have been installed; a monthly fee of fifty cents is charged for using them. How is the club financed? The boys saved quite a sum from the dances, the rest was provided from personal donations. Father Ziter's brother, an Eastman graduate, put on a piano recital, which netted the boys club about $\$ 300$. Fathers mother says she will be glad when he is removed from Selma, as she fears she will have to mortgage her home. The Don Bosco Club is the only club for colored boys in Alabama. ${ }^{101}$

While providing a safe and constructive outlet for the children of Selma was important to the Edmundites, they also stressed the importance of education and made sure that opportunities were available to those who wished to continue their studies. The club sponsored loans and educational scholarships for youth who wished to attend college. For those who did not wish to or could not attend college, the fathers found employment and training opportunities within the community. 102

\footnotetext{
100 Don Bosco was a nineteenth century Italian priest who ministered to the orphans of Turin. In 1874 Don Bosco founded the Society of St. Francis de Sale (Salesians). The order was dedicated to the task of providing homes and education to the unwanted youth of the city. By the priest's death in 1888 there were 250 houses throughout the world that provided home, education, and instruction in the faith to over 130,000 young boys. (Catholic Encyclopedia, cf Bosco and Salesian Society)

101 Chronicles of the St. Elizabeth Convent, 114.

102 Robert Craig Interview by Author (March 18, 1994).
} 
The fathers also took an interest in youth activities outside of the club.

The all-white police force had always treated African Americans in Selma with little, if any, respect; none was given if the individual was a black child. Father Ziter had an arrangement with the police. If any member of the DBBC was to be arrested, he was to be notified. Ziter would then post bail or arrange to have the charges dropped. Robert Craig was at the time a fourteen-year-old member of the club. He recalled that he and a friend were hauled in by the police for flying a kite over the railroad tracks.

The police car came and they got us and put us in jail. There was nothing that you could do. And here, coming down the hallway was this big desk sergeant and he got his book, and asked, "Boy, what's your name?" And we told him. And one of the policemen said, "Aren't you boys from the Don Bosco Boys Club?" We said, "Yes sir." And the policeman said, "Don't bother writing in that book, that nigger-loving priest will be down here before you can get the lock on the door." And sure enough about fifteen minutes later or so, you heard [Fr. Ziter] come in and whistle. He'd always whistle. ${ }^{103}$

The Edmundites provided young blacks with a sense of respect, and as Craig noted, "I am sure that the respect was directed towards [Father Ziter], but he handed it on to us."104

DBBC activities were provided on a non-sectarian basis, but the involvement and dedication of the fathers led a number of club members to convert. John Crear became involved with the DBBC as a teenager, and later

103 Ibid.

104 Ibid. 
converted to Catholicism at age fourteen. He remembered that it was the commitment and activism of the fathers that led him to make his decision.

Interestingly enough, I was a Baptist. I am a convert. My father operated a small grocery store over near Selma University, and every Sunday morning I would listen to the preachers talking about how they had knocked'em dead and how much money they had collected the Sunday before. And I think that was the time that I began to think that there must be something more. About that time I started going to the Boys Club and here were a group of people that were doing something and not asking anything in return, so I guess that is how I became involved . . . I converted that year, talked to my parents about it, and they didn't have a problem with it. 105

While young people made up a large number of converts, many adults converted for the same reasons. However, the Society's emphasis on service to the entire African American community outweighed denominational concerns.

The mission had a major impact on the African American adult community. It provided jobs to African Americans regardless of their denominational membership. These jobs were secure from coercion by the white power structure. 106 Violet Moss started working for the mission as a secretary in 1938. Originally a Baptist, Mrs. Moss later converted. Her husband, Edwin Moss, began working for the Edmundites in 1946 after serving in the Navy during World War II. Moss, a deacon at Brown's African Methodist Episcopal Church in Selma, never converted, but was a key figure in the daily operations of the Mission, directing the Fundraising Department.

105 John Crear interview by author (March 14, 1994).

106 Edwin Moss Interview by author (March 16, 1994). 
Fundraising was always a pressing concern for Casey. In the first years of the mission, the money that Casey had secured for the chapel was barely enough to cover the expense. He set about making personal appeals to his friends and colleagues throughout the country. He purchased a second-hand duplicating machine and sent out an appeal to the alumni of St. Michael's, fellow Vermont clergy, and friends and relatives in New England.

"The Negro cannot give us money. He has none. Hence this letter to ask you to do four things, or at least as many of them as you can. Will you? First, Pray that our Blessed Mother will bless and guide our work (and everyone can do that) for us.

Second, if you are in a position to help us financially, please do so. We are truly in a real tight spot and every little bit will help.

Third, if you have some close friends to whom you can show this letter, will you give it them and ask them to help us also.

Fourth, there are many whom you know might help us, but whom you do not care to approach directly. Will you send us their name and address that we may write direct?"107

Casey answered each response with a personal "thank you." The mission also began publishing a newsletter. The Your Edmundite Newsletter provided updates on the work of the mission and allowed for more efficient fundraising.

All fundraising for the Society's ten Southern missions was done out of the Selma office. By 1942 the fathers had moved the operation out of the parish hall to an office across the street from St. Elizabeth's. The offices included the mailroom and printing room. Casey's handwritten replies were eventually standardized and automated. After a donation was received, a record was created that identified the type of donation and the name and address of the 
giver. A code was assigned to each type of donation. The code referred to what pre-written reply would be sent to the donor. The staff used 28 automatic typewriters. The staff would personally type the proper name and address of the benefactor, and then using technology similar to that used in a player piano, a code was entered into the machine and the appropriate letter was automatically generated. The machines enabled the mission to produce 7,500 pieces of mail a day. The sheer volume of mail the department produced forced the city's Post Office to modernize its facilities. ${ }^{108}$

Moss established a credit union that served the African American community. Originally the plan had been to found a parish credit union; however, the fathers had difficulty gaining approval for the project from State banking authorities. Moss, who was Exalted Ruler of the local black Elks Lodge, organized the credit union through the Elks, while the fathers provided most of the capital. ${ }^{109}$ The Elks Federal Credit Union provided the community with an alternative agency that would not use the loans for political leverage. Moss recalled:

It was really tough for people to go to the banks and borrow money. The credit union was really a help to black people here in Selma. People would come from all over and ask how to set a credit union up. And the fathers would let me go with them. The fathers really wanted me to keep that office running and help anyone who needed help. And that is what I did. ${ }^{110}$

107 Couture, Twelve Years, 3.

108 Crowley Interview by author (July 10, 2001). See also Steven Longenecker, Selma's Peacemaker: Ralph Smeltzer and Civil Rights Mediation, (Philadelphia: Temple University Press, 1987), 43.

109 Chestnut Black in Selma, 91.

110 Moss Interview. See also: Longenecker, Selma's Peacemaker, 44. 
Money from the fundraising operations, weekly collections, and the mission budget were deposited in the Credit Union as capital, and bolstered the deposits of local members. In 1950 the Credit Union's assets totaled three million dollars. ${ }^{111}$

Whites were quick to realize the extent to which the Mission was serving as a bulwark against their traditional methods of economic and political control. Father Couture in his Chronicle noted the many anonymous letters and phone calls "threatening him with dire consequences if he and his companion did not leave town."112 The priests purchased a watchdog for the mission. ${ }^{113}$ They had reason to take the threats seriously. Sixteen years earlier a priest had been murdered in Birmingham. Father James Coyle had officiated at the marriage of a young convert. The groom was Puerto Rican and the bride's father, E. R. Stephenson, was a Methodist preacher and Klansmen. Stephenson shot Coyle on August 11, 1921, on the steps of St. Paul's rectory. The Klan paid Stephenson's legal fees and hired Hugo Black, a young up-and-coming trial lawyer and future Supreme Court Justice, to defend him. The judge and most members of the jury were also Klansmen. The defense admitted Stephenson's guilt, argued that he was "temporarily insane" and forcefully implied that he had a

111 Ibid, 42.

112 Couture Twelve Years, 4.

113 Ibid. Captain was the name of the greyhound. 
right to kill the priest. Stephenson was acquitted on the grounds of selfdefense. ${ }^{114}$

Twice Casey was forced to confront hostile crowds. In the late 1930's, when a mob formed and began to talk of running the priests out of town, Casey armed himself with a pistol and went to meet them. His show of force cooled the ire of the mob and the crowd dispersed. On another occasion in the late 1940s, while Casey was meeting with Edwin Moss, someone knocked at the mission door. Moss answered it only to discover a Klansmen in full Klan regalia. Casey came to the door and with a crushing left hook dispatched the threat. Hostility persisted throughout the early years of the mission so much so that parishioners, armed with shotguns, took turns guarding the mission and the priests in times of racial unrest. ${ }^{115}$

In 1950 the Klan placed a sign on the front lawn of the mission. It read, "The KKK is Looking at You." Other signs had been placed in front of the recently opened black Hudson High School and Tabernacle Baptist Church. The mission issued a statement the following Monday:

We are doing our work while respecting all local customs regarding races; we have nothing to hide, and will discuss any effort at any time in open. Signs which appeared on our Church the past Friday night are a cowardly gesture, and may be compared to the secret police of Russia. ${ }^{116}$

\footnotetext{
114 Albert J. Menendez, "Religious Violence." Freedom Writer, (June 1996), See also: "Bigotry Turns to Murder," The Nation, August 31, 1921, pp. 323, 233 and Roger K. Newman, $\underline{\text { Hugo }}$ Black. (New York: Pantheon, 1994), p. 86.

115 O.S. "Selma Aftermath: Segregationists Take Over After the Marchers Leave," Jubilee (August, 1965), 16. This recounts early years of the mission. See also Edwin Moss Interview by author. (16 March 1994).

116 "The KKK is looking at You," Your Edmundite Newsletter (Easter 1950), 10.
} 
Whites also tried a more genteel approach to the "Catholic problem." A delegation from the Chamber of Commerce came to speak with Casey about Edwin Moss and what they considered an exorbitant salary for whites to be paying "some nigger." During the meeting, Casey asked Moss to step into his office and explained to him "these gentlemen here feel I am paying you too much."117 With Casey's full support, Moss lambasted the delegation and escorted them out. In doing so, Casey further asserted his independence as well as that of the mission. ${ }^{118}$ And while the fathers and Sisters did not challenge the segregation laws, the growing presence and success of the mission challenged the basic tenets of Jim Crow. Their work empowered the black community. In the face of Klan intimidation, the fathers also maintained their sense of humor. The account of the KKK incident in the Easter issue of Your Edmundite Newsletter noted, "If the label above is any indication, our work is at least, at long last, recognized by an organized group."119

Despite the rapid expansion of the mission, the fathers and Sisters continued to address the spiritual and practical needs of Selma's black men, women and children as best they could. In doing so, they clearly identified themselves with the black community. By 1950 the St. Elizabeth Mission was a thriving Catholic mission. In thirteen years, the two priests from Winooski had

117 Selma Aftermath, 16.

118 Ibid.

119 Ibid. 
built a chapel, rectory, convent, parish hall, hospital, school and offices. St.

Elizabeth's provided a spiritual refuge for black Catholics in a hostile white world, but it also provided jobs, education, recreational opportunities, social services, economic development, and medical care for African Americans regardless of their religious affiliation. 120 The Mission was one of the largest employers in the city. The fathers and the Sisters served as liaisons between white and black Selmians. As the new decade began, these religious, economic, and social resources would provide an important foundation for the emerging black freedom struggle that would soon sweep into the city.

120 See E. Franklin Frazier's five point definition of the African American church: a agency of social control, a venue for economic cooperation, as a educational provider, an arena for political and a refuge in a hostile white world. The Negro Church in America. (Schocken Press: New York: 1974), 35-52. 


\section{Chapter 4 : "Heaven."}

"If Selma is heaven, then God keep me out of Heaven."

Amelia Boynton

The St. Elizabeth's mission in Selma had done much to provide for the African American community. But it could only ameliorate the difficulties blacks faced under the harsh form of Jim Crow practiced in the city. In 1952 Harris Wofford, a young lawyer for the Department of Justice, wrote A Preliminary Report on the Status of the Negro in Dallas County. Wofford interviewed the Chairwoman of the Dallas County Chamber of Commerce and asked her about the state of black life in the area. She noted:

The nigger is well taken care of here. I'd say this is a nigger heaven. Segregation there is definitely of course. But no race riots, nothing of that kind. The niggers know their place and seem to keep in their place. They are the friendly sort around here. If they are hungry they will come and tell you and there isn't a person who wouldn't feed and clothe a nigger. ${ }^{1}$

When Wofford told a local black activist that the Chairwomen had characterized Selma as "Nigger heaven," Boynton retorted, "then God keep me out of heaven."2

The reality of black life in Selma was in marked contrast to the image Southern whites projected. In 1950 the median income for Selma residents was $\$ 1,543$, twenty-five percent below the poverty line. The median income for African Americans living in the city was $\$ 856$, almost half the income of whites.

\footnotetext{
${ }^{1}$ Harris Wofford, "A Preliminary Report on The Status of the Negro in Dallas County," in David Garrow (ed.), We Shall Overcome: A Civil Rights Anthology, (Carlson Publishing: New York, 1989),1091.
} 
Although blacks made up just over half of the city's population, 82 percent of black families were defined as living in poverty. ${ }^{3}$

On May 17, 1954, the United States Supreme Court handed down the Brown v. Board of Education decision declaring segregation in public education unconstitutional. As the school year approached, black organizations throughout the South began to press for integration as whites marshaled their forces in order to prevent that from happening. The NAACP instructed each of its chapters to submit a desegregation plan to its local school boards. Montgomery, Anniston, Brewton, Roanoke and Fairfield chapters had submitted their plans by September of $1954 .{ }^{4}$ That year black students were turned away from white schools in Montgomery. In Selma blacks closely watched events unfold in the state capitol. ${ }^{5}$ As a warning to Dallas County parents, segregationists burned two black rural schools to the ground in Dallas County on September 19 and 26, $1954 .^{6}$

The next month local whites organized the first white citizens' council in the state of Alabama. Historian Charles Payne has described the white citizens' council as an organization with "the agenda of the Klan and the demeanor of the

\footnotetext{
2 David Halberstam, The Children, (New York: Fawcett, 1998), 412. The woman was Amelia Boynton.

${ }^{3}$ Census statistics cited in Robert Scott Hereford, "A Study of Selma and Dallas County, Alabama, 1930-1970," (M.A. Thesis: University of Georgia, 1989), 60-1.

4 J. Mils Thornton, "Selma's Smitherman Affair of 1955," Alabama Review, 42:2 (April 1991), 112113. Note: On June 10 Thurgood Marshall in speech in Montgomery at Alabama State College called upon NAACP chapters to press local school boards for integration.

5 Ibid, 113-4.

6 Ibid,114.
} 
Rotary."7 On November 19 a veritable "who's who" of Dallas County's white elite met in the local white junior high school and founded the Dallas County Citizens' Council (DCCC). Founding members included: Dallas County Probate Judge, Bernard Reynolds; Circuit Court Judge, James Hare; Selma mayor, Chris Heinz; Dallas County State Senator, Walter Givhan, attorney and chair of the Dallas County Democratic Executive Committee, M. Alston Keith; and City Attorney, McLean Pitts. ${ }^{8}$ Keith served as the DCCC's first president. Two hundred men joined the group at its initial meeting and within six months that number had grown to 1,200 . By November of 1955 , the Council would claim 1,500 members; a figure which amounted to $25 \%$ of the county's adult white male population. ${ }^{9}$

The involvement of Heinz, Reynolds, Keith and Edwards in the DCCC is indicative of the breadth and depth of the Councils' power. Council members were friends, business associates, political allies and supervisors of each other. DCCC President Alston Keith was a close friend of Heinz and had replaced him as Chair of the Dallas County Democratic party in 1952. Judge Reynolds and Heinz were also close friends, and the two selected the Chair of the DCCC every

${ }^{7}$ Charles Payne, l've Got the Light of Freedom: the Organizing Tradition and the Mississippi Freedom Struggle, (Berkeley: University of California Press, 1995), 35. For a description of the role and tactics of the Citizens' Council see Patterson Brown, 98. See also Longenecker, Selma's Peacemaker, 35.

8 J.L. Chestnut and Julia Cass, Black In Selma: The The Uncommon Life of J.L. Chestnut, Jr. (Politics and Power in a Small Town), (New York: Farrar, Strauss and Giroux, 1990), 82. Chestnut grew up in Selma and attended Howard Law School. He returned to Selma to practice law in 1962.

9 Thornton, "Selma's Smitherman Affair," 116 
year. Edward would eventually serve as Heinz's campaign manager in 1964. ${ }^{10}$ The city's law enforcement, legal institutions, political machinery, businesses and city government were owned or controlled by members of the Council. While the group espoused the use of nonviolent legal means to prevent integration, the DCCC had in its arsenal a full range of options. The Council's apparent antipathy toward the Klan stemmed more from the Klan's failure to recognize the DCCC's legitimate authority and superior social position, than distaste for violence. While the Council publicly presented itself as an independent, nonpartisan, law abiding political group, it was, in fact, the control center for segregationist opposition to Brown, and later to all black political activity. ${ }^{11}$ The triumvirate of the DCCC, the county Democratic Party, and the city government made for a formidable defense of segregation and the status quo.

Lucien P. Burns, mayor of Selma between 1932 and 1949, had established an efficient political machine that had dominated Selma politics since the early 1930s. Burns resigned in 1949 to take a position as president of a local bank. Chris Heinz had served on the city council since 1934 and was Burns' heir apparent. Heinz was from a well-connected political family; both his father and

\footnotetext{
$10 \mathrm{lbid}$. See Footnote 8.

11 The following year, in 1956, the Alabama State Constitution was amended. Section 256 guarantying every child in the state the right to a segregated public education, was removed. The strategy was to segregate children on the basis of non-racial categories and thereby force the NAACP to prove that the separation was based on race. This would require them to file suit in every single school district. See Edward Crowther, "Alabama's Fight to Maintain Segregated Schools, 1953-1956," Alabama Review, (July, 1990), 206-225.
} 
grandfather had served on the city council. Heinz owned an insurance agency with state representative Frank Hardy and fellow city councilmen Mallory Privett. By 1951 Heinz was council president and chair of the Dallas County Democratic Executive Committee. The following year, Ralph Nicholson, who had been appointed to fill out Burns' term in 1949, announced that he would not seek reelection, allowing Heinz to run unopposed for mayor. He would also run unopposed in 1956 and $1960 .{ }^{12}$

The Burns Machine, and Heinz in particular, had not shown any overtly racist tendencies, but in 1953 Heinz's eldest daughter, Jean Heinz Rockwell, claimed that a black man had broken into her home and attempted to rape her. The case was one of many rape accusations that spring. The police eventually arrested William Earl Fikes, a twenty-seven year-old black gas station attendant from the nearby city of Marion, Alabama. ${ }^{13}$ Fikes had dropped out of school at age 16 while still in the third grade. At his trial three psychologists testified that he was slightly retarded, highly suggestible and possibly schizophrenic. Fikes did have a previous run-in with the law. In 1949 he had been arrested for burglary and served two years before being released on parole. After his arrest, Fikes was held in solitary confinement at Kilby State Prison and prevented from having

\footnotetext{
12 J. Mills Thornton, "Municipal Politics and the Course of the Movement," in New Directions in Civil Rights Studies, Armstead Robinson and Patricia Sullivan, (Charlottesville: University Press of Virginia), 38-64, 54.

13 Thornton, "Selma's Smitherman Affair," 115. See also Chestnut Black in Selma, 74. Fikes v Virginia (1955), US Supreme Court.
} 
any contact with his lawyer or family. After hours of interrogation, Fikes confessed to the rape.

The NAACP defended Fikes. He was convicted of assault in a related case and sentenced to life imprisonment. He was also convicted on the rape charge and sentenced to death. Fike's lawyers appealed the rape conviction all the way up to the United States Supreme Court. The court ruled that the confession had been coerced and the conviction was overturned. While the rape charge was reversed, Fikes still had to serve a life sentence for assault. ${ }^{14}$

As a result of the NAACP's involvement in the case, Heinz became ardently opposed to the NAACP and used his political and personal resources to combat the organization and any black activism. ${ }^{15}$ Publicly, Heinz maintained that no racial problems existed in the city. At a City Council meeting immediately following the initial DCCC convention he proclaimed:

Under our present system, each race is free from social discrimination, free from any ill-feeling that would exist if our system were to be changed ... I feel I speak for all of the thinking citizens of our community, both white and colored, when I say to you I am sure that there will be no integration of white pupils in colored schools and no integration of colored pupils in white schools in the city of Selma. ${ }^{16}$

More telling however was an anonymous letter to the local newspaper, the Selma Times-Journal. The letter boldly asserted the means by which local whites would maintain the "Southern Way of Life." The author declared:

\footnotetext{
$14 \mathrm{lbid}, 116$. See also Chestnut Black in Selma, 74.

15 Ibid.

${ }^{16}$ Chestnut Black in Selma, 82.
} 
The white population of this county controls the money and this is an advantage that the Council will use in a fight to legally maintain complete segregation of the races. We intend to make it difficult, if not impossible, for any Negro who advocated desegregation to find or hold a job, get credit, or renew a mortgage.

We are not anti-Negro. We only want segregation maintained. And we are not vigilantes. We will operate openly and violence is the furthest thing from the minds of the Council members. We have lived with Negroes all of these years without trouble, and it is our utmost desire to continue this happy relationship, but on a segregated basis. We have no hatred for the race. In fact, I believe, we have love for the Negro and have his welfare far more at heart than the NAACP. ${ }^{17}$

While the DCCC ostensibly renounced violence, the group made good on its promise to use all other means to quash any attempt to integrate the schools.

A few days before the beginning of the new school year, on August 30, 1955, twenty-nine black parents submitted a petition to the School Board asking that the school integrate. ${ }^{18}$ The petition came on the heels of the Supreme Court's May 31, 1955 decision in Brown II. In that decision the Court instructed that integration plans proceed "with all deliberate speed."19 Buoyed by the Court's language, the parents hoped for some progress on the matter. Selma was the only city in the western black belt to submit a plan. ${ }^{20}$ School Board

\footnotetext{
17 “Open Letter." Selma Times-Journal, November 18, 1954.

18 The parents who signed the petition were: Rev. John D Hunter, NAACP president insurance agent and minister, Rev Seborn Acoff, Otis Washinton, Sadie Mae Washington, Oliver W. Bryant, Rev. L.S. Smith, Lucinda Steele, A.D. Bush, Ethel Griffin,, H.S. Jones, H.W. Shannon, Minnie Bell Harris, Joseph Holmes, Lottie B. Bridges, Elcania B. Page, Isaac Rhodes, Kemp S. Stallworth, J.H. Scott, Romie Small, Velberta Chestnut, Elizabeth D. Smith, Ada Jackson, Joe Vann, Sr., Daisy Phillips, Lela B. Suttles, Ernest L. Doyle, Richard Winston, Daniel Stevenson, Rosa Purifoy. See Thornton, "Selma's Smitherman Affair," 117.

19 Brown v. Board of Education, 349 U.S. 294 (1955)). Supreme Court of the United States.

20 Other locals where plans were submitted were: Jefferson County, Birmingham, Bessemer County, Etowah County, Gadsden, Attallah, Mobile, Montgomery, Macon County, Bullock County,
} 
President Rex Morthland and Superintendent W. Elbert Snuggs announced

on September 6 that the schools would open on a segregated basis and that the board would address the petition the following week.

The DCCC moved quickly against the men and women who had initiated the petition. By September 9, sixteen of the twenty-nine petitioners were fired from their jobs and five had asked that their names be withdrawn, claiming that they did not understand the petition sought integration. The editor of the Selma Times Journal claimed, "These Negroes have maneuvered the white people of the Black Belt into a defensive action which is unpalatable to them."21 The pressure on those who had signed the petition was systematic, ruthless and effective. ${ }^{22}$ Interestingly, the DCCC did not take credit for the firings. Of their role, DCCC president Keith said:

The Dallas County Council has operated entirely within its legal rights in whatever action had been taken in connection with the school petition...[although] the Council does not take credit for the discharge of the petitioners who have lost their jobs, I will say this: I don't believe there would have been the unity of action there was in this respect without the educational work we have done. They [the employers] did just what we have been advocating all along. ${ }^{23}$

The school board met again on September 15, and agreed to refer the integration issue to a committee, effectively burying it.

Butler County, Russell County, Roanoke, Anniston, Tuscaloosa. See Thornton, "Selma's Smitherman Affair," 117.

$21 \mathrm{lbid}, 119$. Edward B. Field, Editor, "Letter from the Editor," Selma Times Journal, Sept 11, 1955.

22 Fred Powledge, Free at Last?: The Civil Rights Movement and the People Who Made It, (New York: Harper, 1991) 615.

23 Thornton, "Selma's Smitherman Affair," 119. 
The black community refused to drop the issue, and initiated a boycott against one of the few white businesses in the city involved with the DCCC that had a large black customer base. DCCC member Edward T. McBride owned the Cloverleaf Creamery. McBride had fired longtime employee Joseph Holmes on September 8 for his involvement with the petition. While most of the Creamery's business was with local Air Force Bases, a substantial portion of the company's customers were African American. The boycott, however, was not public. A white woman, who worked for a competitor of Cloverleaf, noticed the decline in Cloverleaf sales at a small black-owned grocery in Selma and began asking the owner questions. ${ }^{24}$ The owner, John Smitherman and his wife Helena, had moved to Selma in 1925 and bought the store in 1952 . He balked at answering the questions and suggested that she call him later to discuss the matter. In a marked breach of Jim Crow etiquette, he gave her his phone number.

The DCCC quickly learned of the social faux pas and was convinced that Smitherman was hoping to have interracial sex with the woman. The day after the conversation at the store, Smitherman received a phone call at home demanding that he leave town immediately. On October 13, Police Sergeant Clyde Pressley, Lawrence Vickers, C. Benjamin Mitchell, and Billy Mac Bobo kidnapped John Sturdivant, a black porter at a local jewelry store as he rode

\footnotetext{
$24 \mathrm{lbid}, 121-2$. The woman is not identified by name. Thornton's source for the story is an article in the Birmingham World October 21, 1955. See Also Amelia Platts Boynton Robinson, Bridge Across Jordan: The Struggle for Civil Rights in Selma, Alabama (New York: Carlton Press, 1978), 102-104. Note: Robinson identifies the woman as Mrs. Hancock, a being a customer to whom
} 
home from work on his bicycle. The men thought they had abducted

Smitherman, who also rode his bicycle to work. The men eventually released

Sturdivant after he convinced them he was not the grocery store owner. He was told to warn Smitherman to leave town. ${ }^{25}$ Four days later, Selma Police Office William Bailey attempted to set fire to the Smitherman home, but mistakenly attacked the wrong house. Bailey returned the next evening and fired two shots into the correct home, one of which barely missed Smitherman's wife. All six perpetrators were arrested, although none were indicted, and the charges were eventually dropped. Although he was cleared, Sergeant Pressley was demoted to patrolman. On October 25, Officer Bailey, apparently distraught over his involvement in the assaults, committed suicide in his car. ${ }^{26}$ The Smithermans left Selma after the attacks, as did his next-door neighbor, and Officer Bailey's widow. Joseph Holmes, the fired Creamery worker and petition signer, also left town. Billy Mac Bobo went on to serve as a Dallas County Sheriff's deputy. ${ }^{27}$ The Fikes and Smitherman affairs point to the increasing militancy of white opposition to black activism following the Brown decision.

The following year in Montgomery, a determined black community sustained a 360-day boycott against the city's public transportation system, and launched a young Baptist minister, Martin Luther King Jr., into the national spotlight. Two

\footnotetext{
Smitherman delivered milk, and claims their conversation was about improving his business. Thornton located no such person in the city directory for that period.

25 Thornton, "Selma's Smitherman Affair." 122-4.

26 Ibid, 125.

27 Ibid, 125-7
} 
years later the NAACP was banned from operating in the state and fined $\$ 100,000$ after refusing to turn its membership rolls over to state officials. ${ }^{28}$ In 1960 four college students at North Carolina A\&T in Greensboro launched what became known as the sit-in movement. Their quiet protest at the local Woolworth's store sparked similar actions by black college students across the nation. Blacks were challenging segregation in the courts and in the streets.

However, Selma's white elites wanted to make sure that nothing of the kind happened in their city. By 1955 the DCCC had made it almost impossible for African Americans to pursue any issue regarding racial justice in the city or county. Some of the Council's effectiveness can be attributed to the precarious position most blacks found themselves in. The over-all small size of the professional class and its complete vulnerability to white economic intimidation were major factors in limiting the size and scope of Selma's activist community. Since the NAACP had been enjoined in 1957 from operating in the state, there was only a single local organization dedicated to challenging the status quo in Selma.

The Dallas County Voters League (DCVL) had been working to secure the right to vote for all citizens of Selma since the early 1920's, but had floundered due to a lack of interest. C.J. Adams, the league's founder, worked for the Southern Rail Road as a postman, a position that had enabled him a small degree of freedom to challenge Jim Crow. But Adams had been jailed on 
charges of fraud, and in 1953 left town. ${ }^{29}$ William Samuel Boynton and his wife Amelia Platts Boynton had reinvigorated the organization in 1936. Amelia Platts was a graduate of Tuskegee Institute and after teaching for a year in Georgia, she took a job with the Alabama Cooperative Extension Service as a County Home Demonstration Agent in 1930. There she met William Boynton, another County Agent. The Boynton's instructed blacks in home economics and modern farming techniques and strategies. Platts resigned her position in 1936 to marry Boynton. ${ }^{30}$

The Boyntons' work put them in contact with blacks throughout the county. The two were responsible for working with the 15,000 independent farmers, sharecroppers, and tenant farmers throughout the county. Roads often ended at the white plantation home, and the agents were required to lug heavy demonstration equipment through fields and over creeks to "the quarters," often no more than tarpaper shacks with no running water or electricity. On many occasions whites refused the Boynton's permission to come on their land. Large public gatherings, such as county fairs and community sings, were often the only way to keep in touch with large numbers of blacks, as few had telephones and many could not read any mail sent to them. ${ }^{31}$

\footnotetext{
28 James T. Patterson, Brown v Board of Education: A Civil Rights Milestone and Its Troubled Legacy, (New York: Oxford University Press, 2001), 95.

$29 \mathrm{lbid}, 51-54$. A notary public in a town with no black lawyers, he was arrested a number of times for allegedly falsifying documents and eventually moved to Detroit.

30 Robinson Bridge Across Jordan, Introduction, Forward, 41.

$31 \mathrm{lbid}, 82$.
} 
William Boynton helped to organize a black farmer's cooperative.

During the depression, whites refused to sell sodium nitrate, a key fertilizer used in growing cotton, to black sharecroppers and tenant farmers. It was hoped that without the fertilizer, the sharecroppers would have such bad years that they would either fall even deeper into debt or, in the case of independent farmers, default on their loans and be forced back into sharecropping. Boynton arranged for the independent farmers to buy sodium nitrate in bulk wholesale. ${ }^{32} \mathrm{He}$ also preached the value of land ownership and helped farmers arrange for financing to buy their own land. In addition to his work for the Department of Agriculture, Boynton was one of the few black businessmen in town. He ran an insurance agency, real estate agency and later a job placement service. ${ }^{33}$ The Boyntons' government jobs and multiple business interests allowed the couple to pursue activist causes. They revived the local NAACP chapter in Selma with fellow Alabama activists, attorneys Peter Hall and Orzell Billingsley.

In spite of the various forces arrayed against black protest in Selma, Boynton did manage successfully to gain concessions from the white establishment on a number of occasions. In 1935 he petitioned the city to build a community center in the downtown shopping area. Built in 1937 the center not only provided a large venue for social and cultural events, but much needed restrooms and waiting rooms for black shoppers—services that Selma's

32 Ibid, 83-4.

$33 \mathrm{lbid}, 101$. The name of the business was "The Boynton Real Estate and Insurance Agency." 
merchants refused to provide. ${ }^{34} \mathrm{He}$ had also successfully petitioned the City Council to build a recreational facility for African Americans. The city constructed two fishing holes, one for whites and one for blacks. However, when it became common knowledge that the black site seemed to contain the larger fish, the city re-designated the area as "White."35 In 1940 Boynton, coordinated the purchase of a large piece of property in the county to be used as a campground for African Americans in an attempt to provide a facility for blacks outside of white control. While he was constantly pressured to sell the land, he refused. ${ }^{36}$ In 1953 Boynton retired from his job as a county agent in order to devote more time to his protest activities. ${ }^{37}$ In 1958 the Boyntons testified before the Civil Rights Commission in Montgomery. ${ }^{38}$

The modest efforts of the Boyntons and the DCVL attracted a great deal of attention from the white establishment. In 1954 the Boyntons protested the lack of black jurors in the Fikes trial. The DCCC quickly retaliated and pressured the couple's customers to cancel insurance policies and had his creditors call in outstanding loans. It was only by arranging a loan with the Pilgrim Health and Life Insurance Company that the couple was able to avoid foreclosure on their farm. Government officials blocked Boynton's attempt to sell Mutual Funds by denying him a license. They removed his name from the list of voters who could

\footnotetext{
$34 \mathrm{Ibid}, 84$. The city agreed to build the Center only after a white Episcopal priest, Dr. E. W. Gamble, was found who was willing to front the effort.

35 Ibid, 87.

36 Ibid, 89.

37 Ibid, 92.
} 
vouch for those attempting to register to vote. The state refused to grade the gravel road leading to the Boynton's farm in Dallas County. ${ }^{39}$ Any and all means were used to derail black activism.

Many in the community were afraid to associate with the Boyntons in either social or business settings for fear of being branded an activist by whites. ${ }^{40}$ In 1960 the DCCC threatened Sultan Moore, the owner of a prosperous grocery store in Dallas County. The Council had learned that Moore's son was taking part in demonstrations in Montgomery. Moore received a call from the DCCC. The caller demanded that he end his son's participation. Moore replied that, whether he agreed with him or not, his son was a grown man and was acting on his own. Soon the gas and soft drink companies refused to deliver to his store. Moore went to some of Selma's leading whites to discuss the situation. The county sheriff told Moore that he could arrange for deliveries to resume if he could tell him where and with whom the Boyntons were meeting. Moore refused and eventually left the county. ${ }^{41}$ In order to participate in social activism in Selma, one had to be self-sufficient or very discrete about his involvement. As a result of the constant pressure and harassment, neither the NAACP nor the

\footnotetext{
38 Ibid, 138.

39 Longenecker, Selma's Peacemaker, 41. See also Robinson, Bridge Across Jordon, 106-111.

40 Robinson, Bridge Across Jordon, 99-100.

41 lbid, 113-116.
} 
DCVL ever enjoyed widespread support within the African American community. ${ }^{42}$ There was, in effect, no base for a viable protest movement. ${ }^{43}$ In 1952 a young Edmundite, Father Maurice Ouellet, came to St. Elizabeth's to serve as an assistant pastor. The son of French-Canadian parents, Ouellet was born in St. Albans, Vermont, on September 10, 1926. His parents had emigrated from Canada in order to work in the textile mills of New England. His father was a union organizer and was familiar with Catholic teachings on social justice. His parents thought of America "as a special place where people were treated equally." 44 He attended St. Michael's College, and at one of the many talks given by Father Casey, the St. Elizabeth's mission founder, became interested in working in Selma. According to Ouellet, "the question of justice was always a big thing in our family, and the idea of doing things for others was strongly valued. And it sounded adventuresome." 45 He entered the Edmundites and came to Selma a few months after his ordination in 1952. He served as an assistant pastor for four years and then returned to Vermont.

Ouellet returned in the fall of 1960, replacing Father Ziter as pastor. None of the mission staff were involved with any protest organizations. Nor were they involved with the Catholic Interracial movement. Ouellet noted:

\footnotetext{
42 Catrena Norris, "Amelia Boynton's Story" in 25th Anniversary Selma to Montgomery March: How We Got Over the Bridge to Freedom, (National Voting Rights Museum: Selma, 1990), 7. 43 Charles Fager, Selma 1965: The March that Changed the South (Boston: Beacon Press, 1985), 22.

44 Maurice Ouellet Interview by author. (January 4, 1993).

45 Ouellet Interview.
} 
It was really a local thing. It wasn't a national need really that touched me so much. It was the idea of going to a particular place and trying to help people who were there. I had no sense of a national movement probably I had not heard of [Father John] LaFarge at all, although I may have read some articles by him. ${ }^{46}$

Sisters Barbara Lum remembered, "I went to Selma to save the world," but admitted that she was for the most part unaware of the civil rights movement in general and about local activity in particular. ${ }^{47}$ The Sisters did not watch or listen to the news. Magazines provided the Sisters with their only contact with the movement. Recalling how she learned of major news events, Lum said:

I remember working nights and looking through these Life Magazines and people looking with me and people saying this will never happen in Selma. People were in a sense not really ready for it and in another sense very ready for it. 48

Much of what the Sisters learned about life in Selma was gleaned from their interactions with their students at the nursing school and from the hospital and mission staffs. The nursing program drew students from all across Alabama. The impression Lum had was that segregation was noticeably more severe in Selma than in other parts of the state and that "[white Selmians] were harsh and segregation [in the city] was very absolute and unforgiving." 49

The Fathers and Sisters had established a unique place for themselves in the social order of the city. While they were white, they had so completely

\footnotetext{
46 lbid. Father John LaFarge was the church's preeminent spokesman on the issue of racial justice and the founder of the Catholic Interracial Council of New York. See Chapter 2: An Effective Minority."

47 Interview with Sisters Barbara Lum, S.S.J. by author (March 2, 2000).

48 Ibid.

49 Ibid..
} 
identified themselves with the black community that white Selmians considered them black, and only begrudgingly allowed them to exercise the rights and privileges that there color ostensibly entitled them to in Southern society. The Sisters and Fathers fervently believed that all men and women were united in the mystical body of Christ—regardless of race, class and gender. That belief often superceded the very practical considerations that living in the South and working among African Americans required. Sisters Mary Paul Geck recalled:

One Sunday when I was talking with Father Ouellet and I said to him "it seems to me we are colorless." And I remember he was taken aback and said "don't you know you ain't white? We are their Fathers and their Sisters." They never considered us white Sisters; we were just theirs. I thought that was a great compliment. They know that you are totally with them and for them. 50

Black or white Selmians were not likely to misread the clear racial categories life in the South demanded. In order to function effectively, the white Northern Catholic missionaries had to learn that lesson.

The 1955-1956 Montgomery Bus Boycott raised the hopes of civil rights activists throughout the nation. Although Montgomery was located only fifty miles to the east of Selma, no activity took place in Selma as a direct result. In fact the Montgomery movement failed to embolden Selma's black activists, and seems to have hardened white resistance to any challenges to segregation. Two weeks after the boycott began, civil rights attorney Fred Gray traveled to Selma

50 Interview with Sisters Mary Paul Geck, S.S.J. by author (March 2, 2000). 
from Montgomery to represent a client at a hearing. Gray's client was Wesley Jones, an African American Air Force Sergeant, who was stationed at Craig Air Force base on the outskirts of the city. He had been driving through town and had stopped at an intersection behind another car. After the light had changed twice and the car in front of his had still not moved, Jones honked, spoke with the driver and then drove around him. Jones was arrested and charged with disorderly conduct. The couple in front of Jones was white. He had violated a central tenet of Jim Crow—he had challenged a white man.

Gray was well aware of Selma's reputation for the harsh brand of Jim Crow the city practiced. Not wanting to make the trip alone, he traveled to Selma with two friends. In court Gray had to negotiate a dangerous situation. As Gray made his opening statement, the prosecution continuously objected to every statement he made. It took some time before Gray realized that his white colleague was objecting to the fact that he was addressing his client as "Mr." Jones. After a brief conference at the bench, all parties agreed that Sergeant would be an acceptable form of address. ${ }^{51}$ While Gray was in court, his companions, Frank L. Massey and Elbert Hill, took seats in the rear of the courtroom. Almost immediately, a police officer ordered Massey out of the courtroom. He recalled:

\footnotetext{
51 Fred Gray, Bus Ride to Justice: Changing the Sytem by the System-- the Life and Works of Fred Gray-- Lawyer for Rosa Parks, Martin Luther King, Jr., the Montgomery Bus Boycott, the Tuskegee Syphilis Study, the Desegregation of Alabama Schools, the 1965 Selma March, (Montgomery: Black Belt Press, 1994). 98-100.
} 
I asked what I was charged with and no answer was given to me. The word Negro or colored was never used by the police officers; they referred to me and the other Negroes as "niggers." Almost every other word was "nigger." I did not know if anyone knew if I was in jail "52

Massey quickly learned from his cellmates of the violence that Selma police routinely directed against black prisoners. They told him of whippings they regularly received and begged him not to invite the attention of the officers. When Gray finally discovered what had happened, he arranged bail. When Massey was finally released a few hours later on bond, the arresting officer told him:

You niggers got hell going on in Montgomery but this is Selma and Dallas County, and you are not going to start anything here. Tell all the niggers in Montgomery to stay over there. They have no business in Selma, get out and stay over there. If you don't, the nigger undertakers are going to have a lot of business, including them nigger soldiers who testified in court today"53

Selma was determined to maintain the traditional social, political and economic arrangements and would not tolerate any challenges to that cherished way of life. The first major challenge to segregation since the Montgomery boycott would come to Selma in 1961.

That year the Congress of Racial Equality (CORE) planned to send an integrated team of "Freedom Riders" to ride interstate buses from Washington to New Orleans. The teams would test each state's compliance with the new Supreme Court ruling prohibiting segregation in interstate travel facilities. The case itself, Boynton v. Richmond, had an interesting connection to Selma. The

52 Ibid, 100 (see note).

53 Ibid, 
plaintiff in the case, Bruce Boynton, was the son of the city's activist couple William and Amelia. In 1958 while he was returning to Selma from Howard Law School in Washington D.C, Boynton was held over in Richmond, Virginia on a forty-five minute layover. The restaurant in the terminal had one room that was divided into a white and colored section. The colored section had a long wait whereas the white section was empty. He sat down in the white section and ordered a sandwich and some tea. After being asked to leave by the assistant manager and refusing, he was arrested.

Boynton was convicted in Richmond City Court of trespassing. He never denied that he refused to leave the premises. Instead he argued that he was not in the restaurant "unlawfully," noting that the restaurant was an integral part of the station. He argued that as an interstate traveler he could not be denied service solely of the basis of his color because he was protected by the Interstate Commerce Act and the equal protection, due process and commerce clauses of the United States Constitution. He was convicted but appealed the decision in state court and later in federal court. The case eventually made its way to the Supreme Court. ${ }^{54}$ Ironically, the majority decision outlawing segregation in interstate travel was written by Justice Hugo Black, the ex-Klan attorney who had

\footnotetext{
54 John Lewis with Michael O'Dea, Walking with the Wind: A Memoir of the Movement, (New
} York: Simon \& Shuster, 1998), 128. 
defended the Rev. E. R. Stephenson for the murder of a Catholic priest in Birmingham 79 years earlier. ${ }^{55}$

After three days of training, the integrated group of CORE volunteers boarded Greyhound buses in Washington DC and set off for New Orleans. ${ }^{56}$ The Freedom Rides left Washington DC on May 4, 1961 and were scheduled to arrive in New Orleans on May 17, the seventh anniversary of the Brown decision. ${ }^{57}$ The group traveled from Washington through Virginia, from Petersburg to Farmville to Lynchburg and on to Danville. Crossing the North Carolina State line, the group proceeded to Charlotte and them onto Rock Hill, South Carolina. ${ }^{58}$

Few incidents occurred until the group reached Alabama on May 14. The Freedom Riders rode in two groups. The first group was attacked by a large mob in Anniston, Alabama. The mob stoned the bus and slashed its tires. The bus sped out of Anniston but was chased down by the unruly mob of whites. Six miles outside of town the bus was forced to stop and the riders were forced to choose between being incinerated inside the bus or forcing the doors of the bus open and facing a lynch mob. However, an undercover Alabama highway patrolman who had been placed on the bus as a spy forced the barricaded doors

\footnotetext{
55 Boynton v. Virginia (1960). US Supreme Court. For more on the events surrounding the murder of Father Coyle see Chapter 3: "The Harvest Indeed is Great."

56 Lewis, Walking with the Wind, 135. Another group had attempted a similar action fifteen years earlier. Billed as the "Journey of Reconciliation," integrated groups had riden buses through Virginia, Kentucky and Tennessee. However, the demonstration was largely symbolic and never generated a great deal of publicity or support.

57 Ibid, 135-174.
} 
of the bus open with his pistol drawn, allowing the riders to escape the fire.

The trapped protesters fled the burning bus only to run headlong into the angry mob. Floyd Mann, head of the Alabama Highway Patrol, had followed behind the bus in his car. Mann dispersed the mob by firing his weapon into the air. The second group was attacked in Birmingham, Alabama. The Klan had made an agreement with Birmingham's police Chief Eugene "Bull" Connor. The mob waiting was given fifteen minutes without police interference to beat the Freedom Riders. Connor would later claim that, as it was Mother's Day, his officers were home. 59

Bloody and beaten, the protesters discussed whether to continue the Freedom Rides. CORE leaders were considering canceling the demonstration, until Dianne Nash of the Nashville movement arrived and vowed to continue the rides. Nash explained:

If the Freedom Riders had been stopped as a result of violence, I strongly felt that the future of the movement was going to be cut short. The impression would have been that whenever a movement starts, all [you have to do] is attack it with massive violence and the blacks will stop."60

On May $20^{\text {th }}$ the Freedom Rides resumed, this time with police protection from Birmingham to Montgomery. The Freedom Riders opted not to attempt to integrate the Selma station on their way to Montgomery as it was reported that a

\footnotetext{
$58 \mathrm{Ibid}, 142$.

59 Dianne McWhorter, Carry Me Home: Birmingham, Alabama, Climactic Battle of the Civil Rights Revolution, (New York: Simon \& Schuster, 2001), 194. See Also Lewis Walking with the Wind. 145-146.

$\frac{60}{60}$ uan Williams, Eyes on the Prize: America's Civil Rights Years, 1954-1965, (New York: Viking Penguin Inc., 1987) 149.
} 
crowd of over 1,000 had gathered outside the city's bus terminal. ${ }^{61}$ Like the Montgomery Bus Boycott, the Freedom Rides failed to inspire activism in Selma. Sisters Lum recalled, "Some of [our nursing students going home for the weekend] were on a bus with Freedom Riders. They were terrified. They were not part of the movement." 62 Many of the older activists and community leaders thought any attempts would be rash and foolhardy. The fact that the threat of violence had scared away "outside agitators" was a lesson that would not be lost on the city's whites.

As the bus entered the Montgomery city limits, the police escort disappeared. "And then, all of a sudden," recalled Freedom Rider Frederick Leonard, "just like magic, [there were] white people everywhere."63 Jim Zwerg, a white rider, bravely marched off the bus first. As Zwerg was brutally beaten, the other riders slipped off. For the second time in less than a week, Floyd Mann confronted a lynch mob. Unable to disperse the mob, Mann ordered in state troopers. Martin Luther King, Jr., flew to Montgomery and held a mass meeting, surrounded by federal marshals, in support of the Freedom Riders. That evening, while the mass meeting was in progress, a mob of several thousand whites surrounded the church. The marshals were unable to disperse the mob with tear gas, and King feared that they would not be able to hold off the mob if it rushed the church. At 3 am King called Robert Kennedy and pleaded for help.

61 Powledge, Free at Last?, 614.

62 Lum Interview.

63 Williams, Eyes on the Prize, 153. 
Kennedy called Alabama Governor Floyd Patterson and demanded that he deal with the situation. Patterson declared martial law and sent in state police and the National Guard. 64

In spite of the violent opposition, the Riders decided to continue on to Mississippi. However, instead of a mob, state law enforcement officials met the protesters in Mississippi. Robert Kennedy and Mississippi Senator James Eastland had reached a compromise. Kennedy pledged not to use federal troops so long as there was no violence. As the riders exited the bus, they were arrested. ${ }^{65}$ At their trial the presiding judge turned his back on the defense attorney as he made his case and then promptly sentenced the defendants to 60days in the notorious Parchman state penitentiary.

In the hopes of avoiding another state-federal showdown over integration, the Kennedy administration sought to channel the efforts of the major civil rights organizations away from direct action campaigns and into what they felt was a more benign activity: voter registration. Administration officials had repeatedly asked for a cooling- off period after but had been rebuffed. During the Freedom Rides, James farmer, the leader of CORE, had declared, "We've been cooling off for a hundred years, if we get any cooler we'll be in a deep freeze."66 The administration saw two advantages to this change in focus from direct action to voter registration. First, the administration wanted to get the violence that had

64 Lewis, Walking with the Wind, 156-163.

65 Williams, Eyes on the Prize, 146-158.

66 Lewis, Walking with the Wind, 178. 
erupted at recent demonstrations off the front pages of the nation's and the world's newspapers. Second, the administration hoped that a large percentage of newly registered black voters would support the Democrats in upcoming elections. The carrot held in front of SNCC, SCLC and CORE was money. Kennedy promised any organization that undertook voter registration large grants to fund their efforts. The funding for the project came from a number of sources, including the Ford and the Taconic Foundations. The money would be funneled through the Southern Regional Council (SRC) in order to avoid appearing partisan. The SRC plan called for sending field secretaries into communities, along with a projected 20,000 volunteer workers "to bring America's invisible black vote out of the darkness." 67

Bobby Kennedy met with the leaders of the major civil rights organizations to discuss the plan. ${ }^{68}$ King and SCLC gave the plan their endorsement, but not all were enthralled with the proposal. Dianne Nash and others in SNCC felt it was a device "to get the niggers off the street." Others were less antagonistic. Some in SNCC felt that the shift to voter registration was a logical next phase of the struggle. The ensuing debate among SNCC staffers was resolved only after it was agreed to divide the organizations resources between direct action and voter registration. Dianne Nash was chosen to head the direct action wing, and

$67 \mathrm{Ibid}, 182$. See also Clayborne Carson, In Struggle: SNCC and the Awakening of the 1960s, (Harvard University Press: Boston, 1995), 70-71.

68 Ibid, 180. 
Charlie Jones was chosen to head the voter registration wing. ${ }^{69}$ But the Kennedy administration and the Civil Rights activists grievously underestimated the depth of fear Southern whites had for black voters and the lengths to which they would go to prevent it from happening. The reality was, as Powledge states, "voter registration and direct action were the same thing in the deep South."70

$69 \mathrm{lbid}, 181$. See also Carson, In Struggle, 38-40.

70 Powledge, Free at Last?, 478 


\section{Chapter 5 : "Sanct uary."}

Worth came to the back door by way of a sidewalk edged with riotously colorful flowers surrounded by a deep green lawn. But the look on his face was in grim contrast to the surroundings on that beautiful fall day. His body was tense and his face frozen like an infantryman walking through a minefield. I opened the door for him. As he stepped into the room, the mask splintered. His face lit up in a warm smile. He didn't know me from Adam. But the parish hall was sanctuary.

Maria Varela

While the thought of integration in schools, buses and terminals was abhorrent to most white Southerners, the idea of blacks voting was even more frightening. Selma was roughly half black and half white, whereas blacks made up a sizeable majority in the surrounding counties. While the DCCC had forsworn violence in preventing the integration of schools, Selma's white elite was not above using violence to prevent blacks from voting. Only a small number of blacks were registered. In order to prevent any challenges to this prearranged order, the city and the county took elaborate measures to prevent blacks from exercising the right to vote.

State law required that registrars process applicants on the first and third Monday of each month. Between long lunches and slow service on the part of registrars, few blacks even had the opportunity to register. If a person did get the chance to register, he or she had to pass an extensive written test on the state constitution and then face verbal questions from the voter registration board. The board was made up of Selma's leading white citizens. The written exam was graded at the discretion of the registrar, which made him "law unto himself in 
determining the citizen's possession of literacy, understanding, and other qualifications."1 In addition, each potential registrant had to be vouched for by two registered voters. Any problem with the application, testing or vouching would result in the applicant being rejected. African Americans attempting to register were identified by the $\mathrm{DCCC}$ and steps were taken to have the individual fired, to call in any loans he might have, or to suspend credit at local stores. If a person was able to find the time to register, meet the qualifications, pass the test and endure harassment by the Citizens' Council, they could register.

However, a final obstacle awaited them when they attempted actually to vote. A poll tax had to be paid in order to receive a ballot. The tax was $\$ 2.00$ and was cumulative for each year since the applicant had last voted. Back payment of the poll tax often was a financial burden many African Americans could not bear. The numerous obstacles placed before blacks served as a powerful means of limited black enfranchisement. In 1960, although Dallas County was $57 \%$ black, less than $1 \%$ of African Americans were registered to vote, while $66 \%$ of eligible whites were registered. ${ }^{2}$

If the long delays, the requirements, the threat of losing one's job, or the poll tax did not stop an African American from registering and voting, there was always the possibility of violence. The city of Selma was not a stronghold of the Klu Klux Klan. While there were Klaverns in the surrounding counties, Selma's

\footnotetext{
1 David Garrow, Protest at Selma: Martin Luther King and the Voting Rights Act of 1965, (New Haven: Yale University. Press, 1978), 8.

2 Powledge, Free at Last?, 612-613.
} 
well to do had traditionally frowned upon what they considered the baser "unwashed" men who joined the Klan. ${ }^{3}$ However, genteel white Southerners were not above letting an underling do their dirty work. And the man that they chose to enforce their will on blacks was Dallas County Sheriff James Clark. Jim Clark was a "good ol' boy" from Coffee County in Southeast Alabama. He was an outsider and was, by no means, part of the local elite. He had come to the area in 1948 to raise cattle but was unsuccessful. The nephew of Governor Jim Folsom's brother-in-law, Clark had run two of Folsom's gubernatorial campaigns in Dallas County. In 1957 when the Sheriff of Selma died, Folsom appointed Clark to serve out the remainder of the term, despite the fact that he had no law enforcement experience. ${ }^{4}$ Clark was six feet tall, broad shouldered, but carried a bit of a belly. Clark styled himself the "toughest lawman in the region." 5 He wore an Eisenhower jacket with gold epaulets and a white helmet stamped with a Confederate battle flag. One historian wrote that the entire outfit made him look like "a second tier Latin American dictator."6

Clark's full time staff consisted of only nine deputies. In 1960 the sheriff deputized a large group of men to assist him evacuate victims of a flood that devastated the area that spring. ${ }^{7}$ Clark explained that the men served without pay "in times of emergency" when the regular staff was unable to deal with the

\footnotetext{
3 Longenecker, Selma's Peacemaker, 16.

${ }^{4}$ Fager, Selma, 17. See also Thornton. "Municipal Politics and the Course of the Movement." 55.

5 Halberstam, The Children, 417.

6 Ibid, 489.

7 “300 Aides Enlisted By Sheriff," Selma Times-Journal March 30, 1960.
} 
situation. ${ }^{8}$ As David Halberstam has noted "the white men of Selma thought of themselves as volunteers—quick to answer the call."9 Clark and his posse often assisted other Southern cities under "attack" from "outside agitators" in Notagula, Tuskegee, Montgomery, Tuscaloosa, and Birmingham. ${ }^{10}$ The group was made up of day laborers, mechanics and farm hands. None had any law enforcement experience or training. When the floods subsided, the posse was not disbanded. Instead, it served as Clark's private army in the battle against those who might challenge the status quo. The men wore khaki Gl shirts, tan workpants and donned steel helmets with a "Sheriff's Posse" decal. They were armed with electric cattle prods and billy clubs. Clark paid for some of the men's equipment himself. ${ }^{11}$

Clark reported to county court Judge James Hare. Hare was Clark's superior in all aspects of the two men's relationship. A well-heeled member of Selma's white elite, Hare was a graduate of the University of Alabama. He had served in the state legislature as Dallas County's representative and, after serving briefly as assistant state attorney general, he was appointed circuit court judge in 1954. The Judge fancied himself an expert on a number of subjects, including Africa, genetics and Southern history. He held elaborate theories regarding the racial make up of the slaves that had been imported into Dallas

\footnotetext{
8 James G. Clark, The Jim Clark Story: I Saw Selma Raped, (Birmingham: The Sizemore Agency, 1966), 19.

9 Halberstam, $\underline{\text { Children, }} 417$.

10 Baker quoted in Harold Raines, My Soul is Rested: The Story of the Civil Rights Movement in the Deep South, (New York: Penguin, 1988), 198.
} 
County. According to the Judge, the present racial strife could be directly attributed to the poor genetic stock of the descendents of those slaves. Another target of Hare's ire were the Fathers of St. Edmund, whom he referred to as "the popes." Hare "considered them race mixers, un-American and Roman poison."12 In his estimation, the inferior minds of Selma's black citizens were being taken advantage of by two great conspiracies: Communism and Catholicism. Hare placed few conditions on Clark as to how he was to deal with those who challenged the social and political order.

The DCVL recognized that outside help was necessary in order to make progress in Selma. SCLC and SNCC had both looked at Selma and decided not to initiate a campaign there due to the tenacity of the white power structure and the lack of an independent black middle class. The DCVL invited SCLC to come to the city in 1962, but SCLC turned them down citing their commitment in Birmingham. ${ }^{13}$ The man who would reinvigorate the city's protest community was a young SNCC activist named Bernard Lafayette.

Lafayette was born in Tampa, Florida. His father worked as a baker, in steel mills, and as a cabinetmaker. There the center of his family's life was the New Hope Baptist church, which his maternal grandmother had founded. He remembered his grandmother advising him, "Now always stand up for your

\footnotetext{
11 Longenecker, Selma's Peacemaker, 36.

12 Michael Freidland, Lift Up Your Voice Like a Trumpet: White Clergy and the Civil Rights and Antiwar Movements, 1954-1973, (Chapel Hill: University of North Carolina Press, 1998), 118. See also Chestnut, Black in Selma, 184-5.

13 U.S. Commission on Civil Rights Data cited in Powledge, Free at last?, 613.
} 
rights, and don't let anyone walk over you and don't ever be afraid." She would quickly add "and don't get in any trouble with white folks."14

Somewhat of a country boy, Lafayette moved to Philadelphia his junior year of high school. He enjoyed his experience in the urban north where he "felt like I was a real American." 15 He returned to Tampa and completed high school where won a full scholarship to Florida A\&M to study journalism. Rather than take the scholarship, he chose to pursue a career in the ministry. "I liked the idea of journalism," he said, "but I was moved by the idea of serving God."16 $\mathrm{He}$ enrolled at the American Baptist Theological Seminary (ABT), a small unaccredited and under-funded Baptist seminary in Nashville, Tennessee. While at $\mathrm{ABT}$, he became close friends with two other seminarians who would later play crucial roles in the Selma movement, John Lewis and James Bevel. Lewis introduced Lafayette to the workshops on nonviolence being conducted by James Lawson.

Through Lawson's workshops, Lafayette was drawn into the Nashville movement. In the fall of 1960, Lafayette became a full-time activist. He participated in the Freedom Rides and was involved in SNCC's Albany campaign. By 1962 Lafayette was a seasoned veteran of the movement. His wife, Colia Liddell, was from an upper class black family in Jackson, Mississippi. She had attended Tougaloo College and had worked for Medgar Evers and the

\footnotetext{
14 Ibid, 418.

15 Halberstam, The Children, 71.

16 Ibid, 71.
} 
NAACP. That summer the Lafayettes were touring in the Northeast raising money for SNCC.

At the end of the summer they returned to Atlanta where James Forman, executive director of SNCC, offered them the chance to work with Bob Moses in Mississippi. They declined. To date Lafayette had not been in charge of a campaign and he wanted his own project. ${ }^{17}$ He recalled his meeting with Foreman:

"I want to experiment with this thing the way I want to do it and I don't want to end up in jail on somebody else's decision." I wanted to see what really could be done. My theory was to develop a community to the point where the community was willing to go to jail and take a stand. That's when you get change. ${ }^{18}$

SNCC had virtually crossed Selma off its list, and it remained the last unclaimed area. No one wanted it because "previous investigation had shown the intense repression made it unlikely that local people would join a movement."19 However, Foreman had heard that the Department of Justice was planning on giving a "very hard look" at Selma's voter registration practices. The Justice Department felt the city provided "a textbook example of how the white power structure denied blacks the right to vote."20

Lafayette volunteered to "open the Alabama beachhead" for SNCC and was named Director of the Alabama Voter Registration Project (AVRP). He came to Selma the first week of November 1962, in order to survey the city and lay the

\footnotetext{
$17 \mathrm{lbid}, 411$.

18 Powledge, Free at Last?, 614.

$19 \mathrm{lbid}, 614$. Halberstam, The Children. 411.
} 
initial groundwork for his campaign. ${ }^{21}$ Knowing that he would need as much information as he could gather, Lafayette went to the Tuskegee Institute and began to research the history of the city. ${ }^{22} \mathrm{He}$ discovered that all the rumors were true. Selma would be extremely difficult to organize. He learned that after Federal troops had been withdrawn and the South had been "Redeemed" in 1877 , the area had been allotted a number of seats much greater than its population would seem to have demanded. These were apportioned by the state legislature in order to compensate the area for the loss of its slave population. Thus the county played an important role in state politics that belied its size. ${ }^{23}$ Lafayette came to the conclusion that "in order to break Alabama, one had to break Selma and Dallas County." 24 Selma presented a unique opportunity in the struggle for voting rights in Alabama.

Lafayette also went to Montgomery and sought out local activist Rufus Lewis for advice on how to register people in a hostile rural environment. Lewis was the director of a funeral home and the Alabama A\&M football coach. He had been involved in the Montgomery Bus Boycott and had been actively working in voter registration for years. He told Lafayette that the biggest obstacle he faced was not white opposition, but rather "all those years of deadening fear." $\mathrm{He}$ advised him to "go in as quietly as you can, so as not to provoke the white

20 Halberstam, The Children, 412.

21 Powledge, Free at Last?, 614.

22 Ibid, 615.

23 Halberstam, The Children, 412.

24 Ibid. 
people." By maintaining a low profile, Rufus felt that Lafayette would avoid some of the pressure whites might employ against him. The key for organizing was finding those in the community who were most insulated from white pressure, such as retired military personnel and independent farmers. He suggested beginning with small groups and with general discussions of citizenship and constitutional rights. He advised Lafayette to expand his circle of activists slowly and gradually to narrow his focus to registering and voting.

By creating an environment where people could "unburden themselves of the rage which had built up for years," Lafayette hoped to mobilize a committed group that would be willing to risk "the reprisals that were sure to come." 25 However, his first contacts with Selma's black leadership were far from promising, as his reputation as a civil rights activist colored many of his encounters with them. Lafayette noted that fear gripped the entire community. He recalled:

Some people were fearful that I was going to organize demonstrations and get their kids in jail, and we had no money to bail them out. They used to call me "Freedom Rider," because the Freedom Rides were still prominent on their minds. So there were some people who were afraid to identify with me and talk with me. I couldn't find a place to live. ${ }^{26}$

No one was willing to trust a young militant outsider. When he asked a number of the local ministers for permission to hold voter registration meetings in their churches, they turned him down. One minister, in language that mimicked the Heinz letter a few years earlier, declared that Selma had no racial problems. He

25 Ibid. 420. 
then added, "We know how to get what we want from white people. You just have to know how to ask." The minister fell to his knees with his hat in hand. ${ }^{27}$ Having failed to gain the support of Selma's black clergy, Lafayette next went to the Dallas County Voters' League. Rather than praise the group for the work it had done, Lafayette chided the activists. His favorite subject was what he called the "Psychology of Fear." Lafayette asked the group:

What is the limit of the number of black people they'll allow to register to vote? You don't know if that limit has been reached because fear has kept you from testing it. We need to find where the limit of tolerance is. ${ }^{28}$

While it was important for Lafayette to make contact with the League, the group had no resources to offer him and, in particular, no sizeable space to hold meetings.

DCVL member James Chestnut who had recently returned to the city to practice law took Lafayette to the local Elks Lodge. The meeting with the Elk's did not produce any results either, but it did allow Chestnut to introduce Lafayette to an old childhood friend, Edwin Moss. ${ }^{29}$ Moss, in addition to running the Edmundite fundraising operation and the Elks Credit Union, was the Exalted Ruler of the Alabama Elks and a respected member of Brown's Chapel A.M.E. Church. Moss told Lafayette that the pastor of St. Elizabeth's might be supportive of his activities. Moss introduced Lafayette to a parishioner of St. Elizabeth's, John Crear. Crear, since returning to Selma from Xavier University

26 Powledge, Free at Last?, 615, 616.

27 Chestnut Black in Selma. ${ }^{149}$. 
in 1960, was running the Don Bosco Boys Club. Crear introduced Lafayette to Father Ouellet. 30 Lafayette explained to Ouellet that the black clergy were unwilling to allow him the use of their facilities. They were unwilling to risk the repercussions that would result from such brazen support of voting rights. He asked Ouellet if he could use the mission to hold meetings. Ouellet recalled:

We as a white organized church had more financial power and even more moral power I guess. Someone would not be as quick to push a white Catholic priest around as they would a local minister. And so, when he asked me, I saw some of the problems in doing it, but I thought that it was something that we ought to do to help out. But then, of course, the sit-ins were taking place... So we were very much aware of what was going on, but really didn't expect it to happen in Selma so quickly. ${ }^{31}$

Ouellet agreed to let Lafayette use St. Elizabeth's for voter education meetings and adult literacy classes. ${ }^{32}$ The mission's unique position in Selma made it a perfect place for Lafayette to begin his campaign. "I have no family," Ouellet explained, "and am not financially dependent on the white politicians or merchants, so they have no way to get at me in the way they can hurt others." 33 Ouellet was aware of Toolen's opposition to activism but felt that his actions did not require the archbishop's approval. Just as Lafayette and Ouellet were discussing the details of their relationship, the Vatican contacted Toolen to discus the racial situation in the South. Archbishop Egidio Vagnozzi, Apostolic

\footnotetext{
$28 \mathrm{lbid}, 150$.

29 Longenecker, Selma 's Peacemaker, 21.

30 John Crear Interview by author (March 15, 1994).

31 Ouellet Interview.

32 Telephone Interview with Bernard Lafayette by author (18 March 1994).

33 John R. Fry, "The Voter Registration Drive in Selma Alabama," in David Garrow (ed.), We Shall Overcome Anthology, 249-267.
} 
delegate to the American hierarchy wrote Toolen in June and asked about the progress of integration in the diocese. Toolen in a lengthy reply once again declared that segregation did not exist in the diocese. He admitted that he was trying to prepare his diocese for the inevitability of integration, he chafed at the pace of change noting, "If the Communistic dominated N.A.A.C.P. would leave our people alone the day of integration would come much faster." 34 The cost of integration Toolen felt was too great for the church to bear. He explained that the entire Negro Apostolate depended on donations from white Catholics. None of the 29 black parishes, schools, or hospitals was self-supporting and challenging the social mores of the South would cause a severe drop in donations and cripple the Church's outreach to blacks. ${ }^{35}$

Picking up a theme that Toolen often returned to of the rights and responsibilities of African Americans, Toolen blamed black Catholics for failing to live up to their responsibility of supporting Catholic institutions. He adamantly denied that economic inequality was to blame, noting that blacks received "equal wages with the white man in the South today." 36 He defended his policy of proceeding slowly and closed the letter:

You may not believe it after reading this long letter, but I am really on the side of the Negro. However, he is just not ready for what he is asking and won't know to do with it when it comes. To be honest with you I wondered why you asked the question? For almost thirty-six years I have worked closely among the Negroes, have gotten much from them, but as far as

\footnotetext{
34 Thomas Letter Toolen to Edigio Vagnozzi, June 8, 1962. Unpublished. ADMA Diocesan Papers. Box 1962. Apostolic Delegate File.

35 Ibid.

36 Ibid.
} 
teaching them to do unto others as they would have others do unto them, I think my work has failed utterly, it is a blank. If you desire any further information, I will be glad to give what I can." 37

Toolen hoped to delay the inevitable, but the uneasy accommodation Catholics had made with Southern culture was going to be challenged and the crisis would test the limits of the archbishop's leadership and authority.

Colia Lafayette later recalled, "Bernard told me that Selma would be easy. That's not exactly what I would call the truth." The two moved to Selma in February of 1963. However, before they could begin their work, two representatives from the Department of Justice tried to talk them out of staying. Despite the government's interest in using Selma as a test case for illegal voting practices, the Lafayettes were offered scholarships to Columbia University if they would leave the city. They refused. ${ }^{38}$ DCVL members Marie Foster and Amelia Boynton found the couple a place to live. ${ }^{39}$ Margaret Moore, a teacher at Hudson High, the local black high school, agreed to house the activists. In addition to teaching, Moore was owner of a number of properties in the city and provided Lafayette and his wife with both an apartment and an office.

Bernard and Colia Lafayette, along with SNCC staffers Frank Holloway and James Austin, set up the Alabama Voting Rights Project.40 They immediately

\footnotetext{
37 Ibid.

38 Halberstam, The Children, 416.

${ }^{39}$ Chestnut, Black in Selma, 150.

${ }^{40}$ Bruce Gordon, "Field Report: From Bruce Gordon," (Selma, Alabama, November 9, 1963), 2. SNNC Papers (Microfiche).
} 
began to organize voter education classes. Of the initial attempts to bring people into the movement, Lafayette recalled:

People had to have a greater sense of respect for each other. When I was walking around talking to people I would ask them the same question. I'd say, 'Why is Selma like it is?' And to a person they would say to me, "This is the worst place in the world. Nothing's ever going to happen here. These people are so backwards and they're so afraid." And the very people that I was talking to, the same thing was being said about them. Everybody was saying the same thing about each other. So there was a lack of respect for each other, for the ministers, and the other civic leaders. ${ }^{41}$

One of Lafayette's main challenges was "building a community out of a disorganized, disjunctive collection of people." Blacks were afraid not only of what the whites might do to them, but also of what trouble the outsiders from SNCC might bring down on their heads. ${ }^{42}$ Initial organizing attempts were small and proceeded slowly.

Not surprisingly, most adults were less than enthusiastic about SNCC's activities. However, the younger generation was excited. SNCC aimed its initial focus at high school students-who unlike their parents were free from economic harassment, educated and willing participants in the struggle. The plan was to train students to go out and educate the adults about how to register, as well as enlist them in collecting information about the number of potential voters in Selma. Organizers went door-to-door, just as the Fathers had done in 1937 when they were building the mission. But this time, the activists preached a new gospel.

${ }^{41}$ Powledge, Free at Last?, 616. 
Local authorities quickly became aware of Lafayette's activities and began to harass the organizers. Death threats, arrests on trumped up traffic violations, and daily intimidation were the norm. The four SNCC workers complained to the Department of Justice, but were convinced that any information they gave was passed back down to local authorities. Colia Lafayette recalled how she informed SNCC on the status of the organizers. She would place a collect call to the SNCC office in Atlanta. If she placed the call under an assumed name to herself, that meant everything was okay. A call placed to the office under her name alerted the staff that something was wrong. However, as soon as the local authorities identified the couple as activists, they began listening in on their conversations. The operator would often cut in after she placed the call under a pseudonym and say "I know who you are. You're Colia Lafayette, and I know where you are too."43 Three months into their stay in Selma, the Selma Times Journal ran a story on Lafayette and his activities alerting the entire town to their activities. ${ }^{44}$ Some students at the local black college Selma University wanted to participate in the organization but had to withdraw after being threatened with expulsion from college. ${ }^{45}$

\footnotetext{
42 Ibid, 616. See also Carson, In Struggle, 57. Carson notes the psychological importance of militancy for young blacks during the period.

43 Halberstam, The Children, 425-426.

44 Ibid, 426.

45 Gordon, "Field Report," 3.
} 
By June the campaign was beginning to make some progress. The Voter Education clinics were now drawing an average of forty people. 46 Moss and the Edmundite presses provided SNCC with the flyers for the meetings, as the local black printer would not take the job. The mission's parish hall proved too small to hold the larger classes and, unable to locate another facility, the clinics were held outside in tents near the Washington Carter Homes on Sylvan Street. ${ }^{47}$ In spite of the archbishop's clear disdain for activism, Ouellet intensified the mission's involvement in the movement. That same month, to combat the widespread problem of illiteracy, the AVRP set up a number an adult literacy programs at St. Elizabeth's under the leadership of SNCC staff member Maria Varela. 48

Varela had been raised Catholic. Her mother was of Irish and German heritage. Her father, a Mexican national, had immigrated to the United States at a young age. The fact that her father was Hispanic and her mother white proved difficult, and she was forced to confront racial issues early in her life. Her father worked for the chemical companies as a weapons plant safety inspector. His job required the family to move constantly, and Varela joked that she grew up "in the back seat of a 52 Pontiac station wagon." 49 Varela attended parochial schools in

\footnotetext{
46 Lewis, Walking with the Wind, 211.

47 The Washington Carver Homes were the low income housing projects in Selma. They are located next to Brown's Chapel A.M.E. Church; center of later civil rights activity.

48 Powledge, Free at Last?, 613. Mary Varela, My Sixties was not Drugs, Sex and Rock and Roll, Unpublished Memoir. Author's Collection. 19. Carson, In Struggle, 119.

49 Ibid.
} 
Chicago. ${ }^{50}$ In 1961 she graduated from Alverno College and went to work for the Young Christian Student (YCS) movement. YCS sought to minister to the special needs of Catholic high school and college students, and instill in them the same sense of duty and obligation toward their fellow students. ${ }^{51}$ Varela led information sessions for Catholic college students on social justice issues. In her first year as a field worker for YCS the annual program focused on international issues of social justice, such as apartheid in South African. However, in her second year, the program's focus began to shift to the southern freedom movement. 52

In 1962 she participated in a summer literacy program funded by the National Student Association (NSA). SNCC staffer Frank Smith spoke at the NSA summer program and was particularly interested in the work Varela was doing. He told her about the AVRP in Selma. Smith explained to her that the black leadership of Selma was divided. She recalled:

Frank and Bernard felt that the continued support of the pastor of the black Catholic Church was critical to the Selma movement. Father Maurice Ouellet had begun literacy classes in his parish to help prepare people for voter registration. SNCC wanted to find a way to support Father Ouellet's commitment. 53

50 Ibid.

51 The YCS was an offshoot of the Young Christian Worker (YCW) movement. Father Joseph Cardijn had founded the YCW in Belgium in 1927. Cardijn sought to develop a devout Catholic piety in men and women who were entering the working class. Priests sought out Catholics in the work place and tried not only to minister to their spiritual, emotional, and practical needs, but also to instill a sense of duty among the workers toward their colleagues. In 1935 the YCW held its first Congress in Belgium and within ten years the organization was spread throughout Europe. In 1957 the YCS was a well-established international organization. Cf. M. Fievez, "Young Christian Worker," in The New Catholic Encyclopedia Volume 14, 1076-1077.

52 Varela Interview.

53 Varela, My Sixties, 7. Note: Varela misidentifies the mission as the "St. Edmund's" mission. 
A few days later, Lafayette arrived. He and Smith felt Father Ouellet's participation "in some sort of interdenominational effort around voter registration" might legitimize the movement and "dampen down" some of the internal conflicts. ${ }^{54}$ The town men recruited Varela to move to Selma and develop a literacy project based out of the mission.

In October of 1963, Varela flew to Montgomery, where Ouellet met her at the airport. She lived in Selma for eight months researching plans for the Alabama Literacy Project. While she was not involved in parish life, she notes, "Everyone knew that I was associated with SNCC, that I was a civil rights worker so that I was not going to be given any other duties in the parish." ${ }_{55}$ The SNCC staff was convinced that she would be safe and her presence at the mission would not arouse any undue suspicion because people in town were used to "'missionary types' working out of St. Elizabeth's." 56

The ALP had two goals. First, the project sought to empower local people by teaching them how to read. Poor illiterate blacks were often at the mercy of whites. Second, the project hoped it could generate a large number of qualified black applicants who, after the registrars rejected them, would be able to initiate a class action suit against the state. Varela recalled:

Getting large numbers of adults to take that test meant teaching reading. And in those heady days, we anticipated a revolution across the South

\footnotetext{
54 Phone Interview with Maria Varela by author (April 10, 2001).

55 Varela Interview.

56 Varela, My Sixties, 7.
} 
where very shortly black people would be voting and holding office. I felt that literacy would be a critical building block in this revolution. ${ }^{57}$

Alabama's state voting laws required the applicants to demonstrate that they were literate in order to be eligible to vote. John Lewis wryly noted the synergistic relationship that was in place, "how can you deny an education to black men and women and then require it when they reach adulthood to vote."58

Varela surmised that the problem previous literacy projects encountered were an inability to make the students feel comfortable. A major obstacle for adult students to overcome was the presence of white instructors. In addition to finding suitable instructors, she found locating materials to use in the project difficult. She recalled:

As I began researching existing literacy materials, I realized very quickly that they would only make the problem worse. Written by whites about white life, they were framed in a simplistic, childish wording. Shame, it seemed to me, was a huge barrier to learning If SNCC was going to develop a literacy program that would not just teach reading but transform people; materials would have to be created from scratch. ${ }^{59}$

Varela planned to recruit and train black college students to teach literacy in students' churches and homes. She put out a call for summer volunteers through the NSA. Varela's plan was similar to the one being developed by SNCC organizer Bob Moses in Mississippi, but Varela was unaware of the

57 lbid, 8.

58 Lewis, Walking with the Wind, 216.

${ }^{59}$ Varela, My Sixties, 7. 
Freedom Summer project until it came up for discussion in 1963.60 Like Moses' project, the target date for initiating the project was the summer of 1964.

Varela raised money to fund the project and recruited its staff over the winter. By early spring she had hired four black college students. She held two orientation sessions in the North and a weeklong training session at the Tuskegee Institute to prepare teaching materials and methods, as well as to acclimate the students to life in the Deep South. Of the Tuskegee session, Varela noted:

We did some role playing in Tuskegee before we moved to Selma which was interesting because there were white people who were on staff there and somehow it was a little more tolerant than Selma and the central or southern part of Alabama. We did get pulled over by the cops, but they were very different from the cops in Selma. 61

The ALP staff arrived in Selma in June of 1964.

One of the ALP volunteers was Silas Norman. Norman had graduated in 1962 from Payne College in Georgia and was pursuing graduate work at the University of Wisconsin. He had done some organizing for SNCC, working on the Albany campaign in 1961. Varela met Norman in Madison and asked him to join the ALP. He recalled:

We were specifically there to help prepare people for political activity. Advancing your life and doing all those other things would have been important, but we were strictly at that point trying to prepare people to be involved in the political process. ${ }^{62}$

60 Varela Interview.

61 lbid.

62 Powledge. Free at Last?, 620. 
The ALP operated out of St. Elizabeth's parish hall. The program was not

only designed to teach literacy, but to develop a program that might be emulated elsewhere. Varela described the strategy of the ALP:

We were going to create literacy material out of people's own experiences; the way they spoke for example and the things they wanted to learn and integrating black history into it. So that we would maybe end the summer with a curriculum. And my sense was that the students would be turned on by this idea because it wasn't like we were imposing a curriculum on them. Some got it, some didn't."63

The staff would meet daily and discuss approaches to teaching and plan the day's activities. Most of the volunteer/student interaction, however, occurred not in the parish hall but in student's homes.

Varela lived in the white community, while the ALP summer volunteers lived in the black community. The ALP staff tried to maintain as low a profile as possible throughout the summer. ${ }^{64}$ Just as SNCC had hoped, the mission was the perfect venue for whites and blacks to interact on a regular basis without arousing undue suspicion. The mission provided not only cover for the ALP staffers, but also a safe haven for activists. Varela recounted her first meeting with SNCC staffer Worth Long:

Worth came to the back door by way of a sidewalk edged with riotously colorful flowers surrounded by a deep green lawn. But the look on his face was in grim contrast to the surroundings on that beautiful fall day. His body was tense and his face frozen like an infantryman walking through a minefield. I opened the door for him. As he stepped into the room, the mask splintered. His face lit up in a warm smile. He didn't know me from Adam. But the parish hall was sanctuary. 65

63 Varela Interview.

64 Powledge, Free at Last?, 619.

65 Varela, My Sixties, 7. 
Worth Long, a SNCC field secretary from Arkansas who had been working in North Carolina, was assigned to Selma in 1964 to replace Bernard Lafayette. 66 The Lafayettes had been accepted at Fisk University in Nashville and planned to finish their degrees. Another reason for their leaving was that Colia was pregnant.

${ }^{66}$ Lewis, Walking with the Wind, 233. 


\section{Chapter 6 : "The Hottest Places in Hell."}

The hottest places in Hell are reserved for those who in times of great moral crisis maintain their neutrality.

Anonymous

Years of constant community organizing and harassment by disgruntled whites had taken their toll on William Boynton. Boynton' health had failed by the time Lafayette arrived in town, and he now played a limited role in the Voters' League. ${ }^{1}$ On May 13,1963, Boynton died of heart failure. Lafayette sensed that his death might provide a way to bring the black churches into the movement. Boynton was a prominent community activist and a respected member of Tabernacle Baptist. Tabernacle's pastor, Rev. Lewis L. Anderson had been inclined to allow the AVRP use of the church for some time, but the Church's board of deacons wanted no part of the movement. When Lafayette asked to hold a "Memorial service and voter registration drive," Anderson gave him permission without consulting the deacons.

Baptist ministers may have been called by God to preach, but they were paid by the board of deacons. In order to be successful, a minister had to have a working relationship with his deacons. The deacons were incensed. This was not the first run in with the board that Anderson had been forced to deal with. On a number of occasions, the board had attempted to force Anderson out of the church. Some members had accused him of fathering a child with a mistress. 
Anderson had also been involved in a car accident in which a pedestrian had been killed, and his trial on manslaughter charges was under appeal. Dr. William Dinkens, who practiced medicine at Good Samaritan, was president of Tabernacle's board of deacons. He was deeply troubled by Anderson's decision to hold a mass meeting. The deacons were representative of Selma's black elite and wanted no part of a protest movement. Boynton's death, however, had provided Anderson with an opportunity to press the deacons on the issue. Anderson told them that he had been "called to set the captives free" and threatened to set up loudspeakers outside the Church and announce to the public that they were all afraid to open their doors. ${ }^{2}$ Unable to persuade Anderson to change his mind, Dinkens was said to have broken down and cried, "You are deserting your friends and going with strangers."3

The first mass meeting of the Selma movement was held on May 23, 1963.4 Colia Lafayette recalled that evening:

It had rained that night and we were not sure anyone would turn out. We got there and there were black people as far as the eye could see. It was as if you had never seen so many black people in all your life. ${ }^{5}$

Over 350 people attended the memorial service. SNCC Executive Director James Foreman was a featured speaker. He declared that the time to wait was

\footnotetext{
1 James Patterson, Brown v Board of Education: A Civil Rights Milestone and Its Troubled Legacy, (New York, Oxford University Press, 2000), 95.

2 Halberstam, The Children, 422 and Longenecker, Selma's Peacemaker, 22.

3 Chestnut Black In Selma, 163.

4 Alston Fitts, "The Churches and the Freedom Movement," in 25th Aniversary Selma to Montgomery March, ed. Octavia Vivian (Atlanta: SCLC Publication, 1990), 15.

${ }^{5}$ Halberstam, Children, 422.
} 
at an end. However, not all those on the podium harbored enthusiasm for the movement. The Rev. C. C. Hunter, pastor of the Clinton Chapel AME Zion Church gave a conservative rebuttal to Foreman's speech. Hunter's theme was "love thy neighbor and let God fight your battles." He proclaimed that the "black man's problems were his own making" and the community needed to clean up its own act before anyone could begin to request "some of the things that have been mentioned here tonight." The congregation greeted his remarks with a stony silence. ${ }^{6}$ The mood, it appeared, was changing in Selma.

During the service, Sheriff Clark and his posse of ruffians lined up along the street around the church. It was standard operating procedure. Clark made a habit of appearing at large gatherings in order to reinforce his authority. ${ }^{7}$ The posse men carried wooden bats, actually unfinished table legs from a local furniture store many of which had special steel rods inserted into their centers. ${ }^{8}$ While the service was in progress, posse men took down license plate numbers of those attending the meeting, and broke taillights so that traffic tickets could be issued to them the following day. The information was passed along to the

\footnotetext{
${ }^{6}$ Longenecker, Selma's Peacemaker, 45 . Hunter's remarks were given almost exclusive coverage by Selma Times Journal Editor Arthur Capell the following morning. Cf. Longenecker, Selma's Peacemaker, 240. Arthur Capel, "Voter Registration Rally Concluded Quietly Here," Selma Times-Journal. May 15, 1963.

7 Halberstam, Children, 418.

8 Ibid, 423.
} 
DCCC. ${ }^{9}$ Judge Hare later ruled that the sheriff had a right "to protect and maintain public safety."10

Sisters Barbara Lum watched the scene from the convent which was next door to Tabernacle. Everyone who exited the church was forced to pass through a gauntlet of sheriff's deputies and possemen. She recalled:

And when the people came out into streets, [they] were lined with very hostile white men [They] came out in total silence. It was like a church procession. ${ }^{11}$

Instead of discouraging participation in the movement, Clark's intimidation seemed to have the opposite effect. Colia Lafayette felt that Clark's bullying backfired and that he was, in effect, forcing Selma's blacks to choose sides by making it impossible to remain neutral. "The basic lesson learned," she thought, "was not about integration; it was more basic. It was about whether a man could stand up and act like a man."12 The meeting was an important breakthrough in the AVRP. Another meeting was held later that month at Clinton Chapel A.M.E. Zion Church.

In response to the success Lafayette and the other SNCC organizers were enjoying, whites escalated their efforts to derail the movement. Late in the evening on June 11, 1963, Lafayette pulled his car up in front of his apartment. The apartment was located in an area where a black and white neighborhood

\footnotetext{
9 lbid, 424.

$10 \mathrm{lbid}, 425$.

${ }^{11}$ Barbara Lum Interview by author (March 2, 2001). At the time, she was known as Sisters Eleanor. She later reverted to her given

12 Halberstam, Children, 424-5
} 
came together, and so he was not too surprised to see a small group of white men ahead of him. They appeared to be having trouble with their car. One of the men approached Lafayette and asked him, "How much do you charge for a push?" Their car was a pink and white '57 Chevy — a "good 'ol boy car." Lafayette's was a ' 48 Chevy. His car had been issued to him from the SNCC motor pool. He recalled that it was perfect for civil rights work. It was "like a tank [with] four heavy doors and small windows" and it provided ample protection from attacks. Lafayette agreed to assist the men, and he slowly drove his car up behind theirs. One of the men said, "You better get out here and take a look." To which he replied, "What's the matter? Aren't the bumper guards matching?" As he opened his door and leaned out to see, he was hit from behind with what he thought was the butt of a gun. The blow knocked him down. He tried to rise twice, and both times he was beaten back to the ground. The third blow left a deep gash in his forehead.

The commotion brought some of Lafayette's neighbors to their porches. One brandished a shotgun, whereupon his attackers fled. Even though he was dazed from the assault, Lafayette screamed to his neighbor not to shoot. He knew that Clark would use any aggressive action to charge him with attempted murder. He was taken to Burwell Infirmary where he received eleven stitches for the gash in his head. ${ }^{13}$ That night NAACP organizer Medgar Evers was

\footnotetext{
13 See Howard Zinn, "Alabama: Freedom Day in Selma," in The Zinn Reader: Writing on Disobedience and Democracy, (New York: Seven Stories Press, 1997), 76. See also Halberstam, Children, 426-7.
} 
assassinated in front of his home in Jackson, Mississippi. Another attack was thwarted in Louisiana when the intended target, a CORE activist, failed to show up at a meeting. ${ }^{14}$

James Chestnut encountered Bernard still wearing his bloody shirt the following morning. He refused to stop organizing and intensified his schedule. Of his decision to continue working, Lafayette said:

The first thing that you have to do when people are afraid is to give them other models and examples of courage. See, the models and examples they had had been the people who had been beaten down and killed.

People had been run out of town; lost their jobs. It was a consistent pattern. So why should they believe what I said? Well, seeing is believing. So I was beaten in the community and arrested. . . The next day, I got out of the hospital and organized them for a mass meeting. I provided the role model for people; the beating did not stop me from continuing my work. ${ }^{15}$

In spite of Lafayette's stoic efforts, attendance at mass meetings, adult literacy classes and DCVL meetings remained low through August of 1963.

The black community was by no means united. Personal and theological squabbles prevented a number of prominent black leaders from cooperating with each other and private foibles made a few activists unlikely to gain widespread support. The Reverend Ralph Smeltzer, a Church of the Brethren minister who came to Selma in 1962 to attempt to mediate the city's racial strife, made the

\footnotetext{
14 Halberstam Children, 427-428, and John R. Fry, "The Voter Registration Drive in Selma Alabama," in We Shall Overcome: Anthology, 256.

15 Powledge, Free at Last?, 616. See also Bernard Lafayette, "SNCC and Selma," in 25th Anniversary Selma to Montgomery March, ed. Octavia Vivian (Atlanta: SCLC Publication, 1990), 9
} 
most careful assessment of the city's black leadership. ${ }^{16}$ Smeltzer spoke with white and black leaders over a three-year period in an attempt to facilitate an interracial dialogue and to prevent violence. Smeltzer kept extremely detailed notes on his conversations and of his and other's impressions of the situation. The most obvious choice for community leader was Amelia Boynton. By far the most outspoken and active of the black leadership, Boynton was perceived as too militant by whites and, therefore, Smeltzer felt she would not make an effective leader. Smeltzer felt that the three key black leaders were Frederick Reese, the Reverend Claude Brown and Edwin Moss.

Reese, Smeltzer felt, was capable and committed, but his job as a teacher placed him in a very vulnerable position. In a letter to local white businessman Art Lewis, Smeltzer gave his assessment of Reese's ability:

He is the only man who so far in the Negro community has been able to get all segments of the Negro community working together. He has been able to do this, not only because he is a natural leader, but because he understands persons and the psychology of human relationships better than most any other Negro leader in the Negro community. Also, he is a man of integrity and principle. Generally he knows when to speak and when to be quiet. Because of these qualities he has been able to get Brown and Moss working together, which has been quite a feat in itself. ${ }^{17}$

Brown was the most conservative of the three, and he distrusted the young SNCC workers who had come to Selma. While he approved of the goals of the movement, he hoped to avoid demonstrations. Brown also had a drinking

\footnotetext{
16 For a complete examination of the role Ralph Smeltzer played in Selma see Longenecker Selma's Peacemaker.

17 Ralph Smeltzer Letter to Art Lewis. October 9, 1964. RSP (Microfiche, Reel 2)
} 
problem. ${ }^{18}$ Moss was a moderate, and while his job was secure, he had a number of commitments around the city including the credit union, a family grocery store, the Elks Lodge and his job at the Mission. He could not always be counted on to attend meetings. Brown and Moss often attended meetings only when they were scheduled to speak. ${ }^{19}$ Similarly, Moss and Brown had a longstanding feud. Brown was a fervent anti-Catholic, and while Moss was a deacon at Brown's Chapel A.M.E Church, Brown accused him of trying "to infiltrate Protestant groups with the poison of Romanism."20

SNCC organizers constantly emphasized that the vote was an essential tool blacks could use to address a number of important concerns such as quality education for their children, paved streets, decent housing, police brutality, jobs and taxes. In order to press the city council into dealing with these concerns, Dr. William B. Dinkens, Edwin Moss, Reverend Frederick Reese, the Reverend V. T. Minnifee, Father Ouellet, Reverend Lewis Anderson, Reverend Brown and Reverend C. C. Hunton, founded Dallas County Improvement Association (DCIA). ${ }^{21}$ Moss invited Ouellet to join the DCIA. Ouellet described the organization as:

A businessman's organization also made up of church leaders. And that if we were going to have someone come in from the outside, we wanted to have some say in what is going on..22

\footnotetext{
18 Ralph Smeltzer, “Smeltzer Interview with Frederick Reese”, July 17, 1964. RSP (Microfiche, Reel 3)

19 Longenecker, Selma's Peacemaker, 74.

20 lbid, 45.

21 Alston Fitts, "The Churches and the Freedom Movement," 15.

22 Maurice Ouellet Interview by author (January 4, 1994).
} 
The group consisted of a broad cross section of the African American community and represented the strongest coalition of black community leaders to date.

The DCIA submitted a petition to Mayor Heinz in the first week of August. The Mayor and the Chamber refused to see the delegation and directed them to contact the city's Police Chief, Ed Mullen. The letter informed Mullen that the group came to him "as representative of the Negro citizens of Selma by virtue of the fact that we have for better than four months now been discussing the racial problems as they exist now and we are able to foresee what they will be in the near future." The letter noted that the DCIA had been established in order to avoid the necessity of demonstrations and potential violence by establishing "positive but friendly lines of communication between the races" in order to present the concerns and grievances of Selma's black community. ${ }^{23}$ Later that month, the group then sent letters to all of Selma's business owners and government officials requesting jobs and equal pay for blacks, courtesy for customers, and the removal of all white and colored signs from stores and public buildings. ${ }^{24}$ The letter read:

We see no reason to make this a threat; however, every businessman must know that the Negro wants to do business now where it is appreciated. His desire to spend his money with those who treat him as a customer and give him the opportunity to benefit from its profits by giving him employment other than janitors, maids, and porters. ${ }^{25}$

23 Dallas Improvement Association Letter to Ed Mullen. August 8, 1963. RSP (Michrofiche, Reel 2).

24 Dallas County Improvement Association Letter to All Businesses. RSP (Microfiche, Reel 2). 25 Ibid. 
The group requested a reply by September 15, and noted that the lack of one would be interpreted as a rejection of the association's proposals.

On July 23, 1963, Ouellet wrote to auxiliary Bishop Joseph Durick in Birmingham. At the time, Toolen was in Rome for the Second Vatican Council. Durick was a native of Alabama. Born in Bessemer in 1914, Durick lived through the high point of anti-Catholic violence in Alabama. He had entered St. Bernard's College in Cullman, Alabama, after graduating from high school. He graduated in 1933. Toolen sent Durick to St. Mary's Seminary in Baltimore and then to the Urban College in Rome to complete his studies. Durick was ordained on March 23, 1940 in Mobile. He then joined Father Frank Giri's North Alabama Mission Band, a Catholic evangelizing group that lead outdoor revivals and missions throughout the state. ${ }^{26}$ The Band sang "non-heretical" Protestant hymns, preached and answered questions about the faith. ${ }^{27}$ When asked by one curious onlooker where his horns were, Durick replied, "I'm kind'a young. I haven't grown my yet."28

Durick was named auxiliary Bishop of Mobile-Birmingham in 1954, making him the nation's youngest Bishop. He had been assigned to the diocese out of concern for Toolen's age and health. It was hoped that he might alleviate some of the administrative duties the large diocese demanded of the aging archbishop.

\footnotetext{
26 Note on mission bands. Cf Fogarty. 27 Jonathon Bass, Blessed are the Peacemakers: Martin Luther King Jr., Eight White Religious Leaders, and the "Letter from Birmingham Jail," (Baton Rouge: Louisiana State University Press, 2001), 54-57.

28 Ibid, 57.
} 
Durick's experience and age do much to explain the difference between his approach to the race question and Toolen's. Durick had asked the Archbishop whether he wanted to integrate the parochial schools in light of the Brown decision. Toolen declined to do so and cited his fear of violence as his reason for delaying. ${ }^{29}$ For years Durick and Toolen had clashed over integration. At one point Durick had confided to Toolen, "My generation will have to face up to the [racial] question and you and your generation will not. You're past that age."30

Durick's experiences at school in Rome and as an evangelist in Alabama enabled him to develop working relationships with non-Catholics. Whereas Toolen refused to participate in ecumenical gatherings Durick was comfortable preaching in a Protestant milieu and was heavily involved in interfaith activity. He met regularly with white Protestant ministers and a rabbi to discuss the city's racial ad political situation. The group, the Birmingham Ministers' Association (BMA), had issued a statement following Wallace's 1960 inauguration. While the statement did not name the governor, it was a rare Southern white criticism of Wallace's inauguration speech. The statement consisted of seven points:

1. Hatred and violence had no sanction in American religious and political tradition.

2. Disagreement over laws and social change should never lead to defiance, anarchy and subversion.

3. Courts and legislatures had the power to review and change laws but laws "could not be ignored by whims of individuals."

4. Citizens had the right to amend the constitution or impeach judges through proper action but, in the meantime, America's way of life depended upon obedience to court decisions.

29 Bass, Blessed are the Peacemakers, 60.

30 lbid. 
5. No person's freedom was safe unless everyone's freedoms were equally protected.

6. The first amendment right of free speech must be "preserved and exercised" without fear of recrimination or harassment.

7. By being created in God's image, every person deserves respect and all basic rights, privileges, and responsibilities. ${ }^{31}$

The reaction to the statement was swift. The Birmingham Post Herald ran an editorial that predicted the BMA members who had signed the statement would face retribution from the more forceful segregationists in the community. ${ }^{32}$

During the SCLC campaign in Birmingham, the BMA called for restraint on both sides. On April 13, 1963, Durick and the BMA issued the "Good Friday Statement." They criticized King and the SCLC as outsiders and called for restraint on the part of demonstrators and law enforcement officials. A few days later, Birmingham Police Chief "Bull" Conner ordered fire hoses and police dogs turned on demonstrators in Kelly Ingram Park. Soon afterwards, Martin Luther King issued his "Letter from a Birmingham Jail." Technically addressed to the eight Birmingham Ministers Association members who had signed the "Good Friday Statement," King's letter was, in fact, a forceful and carefully constructed retort to the "white moderate" stance that the ministers represented. King's "Letter" was never sent to any of the ministers. Instead, it was released directly to the press. Durick was deeply moved by the letter, and experienced what he called a personal transformation as a result of the experience. But in December

31 Ibid, 19-20.

32 Ibid, 20. 
of 1963, Durick was appointed coadjutor Bishop of Nashville, and an important ally for the movement was lost. ${ }^{33}$

In July, Ouellet informed Durick of his plans to arrange a meeting of Selma's ministers to discuss the present situation. He said that he had contacted the Rev. Warren Lindsey, the District Superintendent of the Methodist Church in Selma. Ouellet sought to address the Dallas County Christian Ministers Union (DCMU). Lindsay had delayed calling the meeting, feeling that it would be more prudent to wait until all of the clergy had returned from their summer vacations. However, Lindsay and some other ministers did agree to discuss the details of the proposed meeting on July 24 at St. Elizabeth's. While he sensed that Lindsay was reluctant, Ouellet was encouraged by what he saw as the minister's willingness "to do whatever he could to be of assistance to the city by presenting a united front." He wrote:

Things have remained very quiet here in Selma. It would seem that the white people in town are hoping that nothing will happen and that everything will just return to normal. At the same time there is a great deal of tension and fear on both sides. I do feel that there has been some very wise restraint on the part of leadership of both parties but it is impossible to determine whether this is a lasting condition. It would seem that neither side is willing to compromise. I would hope that a meeting of the ministers in the city will help to ease the present tension. ${ }^{34}$

In September the city was near the breaking point as no progress had been made in months. Younger activists wanted demonstrations to protest the city's complete failure to address the movement's concerns. With tensions rising, and

33 As coadjutator, Durick had the right of sucession.

34 Maurice Ouellet Letter to Joseph Durick, July 23, 1963. ARC Ouellet Papers. Box 1 Folder 1. 
still no substantial participation by adults, the movement lost two of its key organizers. Bernard and Colia Lafayette left Selma that month to resume their studies at Fisk University in Nashville. SNCC organizers Worth Long and Prathia Hall replaced them.

Ouellet's hopes that a joint statement by the Selma's white clergy might create an atmosphere in which face-to-face negotiations could take place were dashed on September 14, 1963. That morning a bomb exploded at the 16th Street Baptist Church in Birmingham, and four young girls were killed while attending Sunday school. The bombing severely tested the nonviolent discipline of the movement and dramatically increased the threat of violence throughout the South. Ouellet, feeling that a statement on behalf of the white clergy of Selma might be the only means of preventing an outbreak of violence in Selma, intensified his efforts to convene a meeting of the city's white clergy.

Both Archbishop Toolen and Bishop Durick issued statements condemning the attack. Toolen was "shocked, amazed and grieved by the dastardly act" and pleaded with his parishioners:

If there are any of our Catholic people with hatred in their hearts for their Negro brethren (and I pray God there are not), but if there are, I plead that they will pluck this hatred out of their hearts, and remember all men are created equal, all are redeemed by the precious blood of Christ. Though their color may be different than that of the white man, their souls may be much whiter and more pure than those seeking to destroy them. ${ }^{35}$

35 Thomas J. Toolen, December 3, 1963, "Church Bombing Pastoral," ADMA. Box: 1963 File: Unfiled. 
He requested that the community and law enforcement work diligently to bring those responsible to justice. Durick asked that all of the city's clergy attend the funerals of the girls together as a show of support and solidarity. The ecumenical and interracial group walked to the Church and sat as Dr. King gave the eulogy. ${ }^{36}$

Ouellet spoke to an emergency session of the DCCMU the next day. This was not the first time the Ministers Union had failed to address a difficult issue. A year earlier, the Reverend George Hrbek, pastor of the Trinity Lutheran Church had objected to another minister's biblical defense of segregation, whereupon the "wrath of the Citizens' Council descended upon him."37 He requested the DCCMU issue a statement in support of freedom of speech. The DCCMU refused. Eventually, Hrbek was forced to leave town. ${ }^{38}$ To date the DCCMU had been unable to reach across racial lines and was unwilling to take any moral initiative by taking a stand on any controversial issue. Ouellet called the DCCMU and said, "that it was a disgrace that not one person would vote for racial justice and that no one would vote against violence."39

Ouellet suggested that the ministers issue a statement as individuals and not as representatives of their congregations. He recommended it support the right of all Americans to vote. That proposal was defeated. Ouellet then urged the ministers issue a statement deploring violence by all parties. That too was

\footnotetext{
36 Bass, Blessed are the Peacemakers, 181.

37 Longenecker, Selma's Peacemaker, 36-37.

$38 \mathrm{lbid}, 36$. Hrbek went on to work in the Probation Friend Project in Cleveland, Ohio.
} 
defeated, this time on a technicality. According to the union's by-laws, in order to vote, each member had to have paid his yearly dues of one dollar. The ministers did not wish to antagonize any member of the group by asking for money, as "it was felt that the taking of a vote would prove more divisive than helpful." 40 Just as the city government had summarily dismissed the requests of the movement leadership, the Ministers Union, whose mission was "to crystallize the moral and spiritual sentiment of Dallas County and thus cause the impact of this cooperation to be felt upon the life of the county," was unable to even muster a vote. 41

Ouellet had a sign hanging above his desk that read: "The hottest places in Hell are reserved for those who in times of great moral crisis maintain their neutrality." 42 Ouellet felt as if the ministers had abdicated their responsibility as the moral leaders of the community, and the following week, he left no doubt as to how he felt about their inability to act. Incensed, Ouellet wrote a letter to the editor in which he lambasted the ministers. ${ }^{43}$ Members of the DCCMU were outraged at Ouellet's public harangue in the Selma Times Journal. DCCMU

\footnotetext{
39 Ouellet Interview.

40 "Emergency Meeting-- Dallas County Christian Minister's Union." Minutes of meeting held on September 16, 1963. Selma Mission Archives.

41 lbid.

42 Ibid. See also Franklin McMahon, “These are my people.” July 4, 1965, Chicago Sun-Times. Note: The quotation can not be attributed to either Dante or a Dante scholar. Rather it is a popular observation referring to the fact that in the Inferno, Dante reserves a special place outside the gates of hell, in hell's vestibule so to speak, for those who did not take a side but chose to be neutral when faced with difficult moral choices. They are not even worthy of hell Dante seems to say. See Inf. Canto III, 31-75. I am most grateful to Professor Theodore J. Cachey Jr., Director of the William and Katherine Devers Program in Dante Studies at the University of Notre Dame, for his help in this matter.
} 
member, the Rev. George Privet wrote Ouellet personally to register his disgust with the priest's actions. Rather than seeing the meeting as a failure, the members thought that an important first step had been taken. Privett wrote:

What did you expect to accomplish by your letter? I refer particularly to your reference to the religious leaders of our community. A basic law of psychology is to win the confidence of another before he can influence him for good Although you had not won the confidence of the group, you were permitted the privilege of airing your views before the Dallas County Christian Ministers Union. Something was started that could have been built upon. However, since we failed to take action you felt to be imperative, we have (according to you) become criminals and our persons and ministries publicly ridiculed. Such action is unfair and a breach of trust. ${ }^{44}$

Ouellet's frustration with his colleagues allowed his temper to get the better of him and derailed any possibility of future meetings. But he was correct in assuming that events in the city were deteriorating, and his inability to persuade the DCCMU to issue a statement illuminates the limits the white moderate could play in the city. No minister was willing to challenge the staunch segregationists who controlled the city and county. The DCCMU would not address the issue of racial unrest again until March 8, 1965.

News of the bombing and the children's deaths made any hope of delaying demonstrations impossible. As Ouellet met with the DCCMU, five high school students staged a sit-in at Selma's Carter-Walgreen drugstore. All of the demonstrators were arrested, but not before two were beaten by white bystanders. The beatings further intensified the demonstrations. On September 18 , SNCC held a demonstration outside the courthouse. It was interrupted by a 
white man who leapt into the crowd of protesters with what appeared to be a large black snake. He ran up to James Gildersleeve, a teacher at the local black Lutheran Academy and member of the DCVL, and attempted to force the snake into his mouth. ${ }^{45}$ John Crear, who was now working at Good Samaritan Hospital, intervened and knocked the snake out of the man's hand.

That afternoon, Crear had driven by Brown's Chapel to check up on the day's events and was chatting with Gildersleeve and some of the other movement leaders. Crear did not participate in the demonstrations, but was supportive of the movement. "I did whatever I could to do but did not put myself in a position where I would get hit," he said. "I was not nonviolent and knew that if hit, I would hit back." While he avoided marching, he did whatever else he could to help the movement. . ${ }^{46}$ He remembered:

Well, we saw this white guy and he was walking down towards us . . and whatever he had in his hand made the people in front of the church move back. We walked over towards him. He poked Mr. Gildersleeve and Mr. Shanon. He poked me, and not being nonviolent, I didn't back up . . All I know is next minute I had Jim Clark on me with a billy club in my back telling me that I am under arrest. ${ }^{47}$

Both Crear and the snake handler were arrested. Crear was charged with assault and battery, while the attacker was charged with attempt to incite a riot. ${ }^{48}$ Two days later the student body of Hudson High walked out of classes and marched to the courthouse to protest his arrest.

44 George Privett Letter to Maurice Ouellet, September 23, 1964. ARC Box 1, Folder 1.

45 Fry, "The Voter Registration Drive in Selma Alabama," 263. Note: The snake was plastic.

46 John Crear Interview by author (March 15, 1994).

47 Ibid. 
Ouellet's participation in the movement had not gone unnoticed by whites in the city, or diocesan officials in Mobile. Both kept a watchful eye on the priest, as they were convinced he was playing an essential role in the movement. A few months after the arrival of SNCC in 1963, the city convened a grand jury to determine who was behind the unrest. While the Dallas County Voters League had been operating in Selma for over thirty-five years and had publicly extended the invitation to SNCC to head the voting rights campaign, the grand jury focused its attention on Ouellet. He recalled that as time passed, "the sentiments seemed to be in Selma that there was a white priest involved in all of this and, therefore, he must be at the root of it all because black people could not do this themselves."49 The grand jury found nothing with which to charge the priest.

City officials told Ouellet that he would be arrested if he continued to attend mass meetings. He ignored the warnings. After his first mass meeting following the warning, he prepared for jail. "I put on clean clothes picked up a toothbrush, put my breviary in my pocket and was ready," he said. "Nothing happened, so I went to bed." 50 Surprisingly, the authorities took no action. On Sunday, September 20 Mayor Heinz requested a meeting with Ouellet and Father Galligan. Also attending the meeting were County Solicitor Balinshard McCloud, and Probate Judge Bernard Reynolds. He was asked to take an "extended

48 Barbara Lum Letter to Parents. Septmber 18, 1963. Author's Collection.

49 Ibid.

50 John Cogley, "Archbishop Ousts Priests at Selma," New York Times, June 26, 1965. 
vacation" in order to "protect himself" from possible violence. ${ }^{51}$ He refused. Ouellet informed the officials he was aware of the danger. "I felt my job was here," he explained, "and I wasn't about to run away from it."52

That evening Heinz called Father Eymard Galligan, the Director of Southern Missions. Unable to convince Ouellet of the need to leave town, the delegation tried to pressure Galligan into reining in the priest. Galligan refused to curtail Ouellet's participation. ${ }^{53}$ Ironically, Ouellet had no experience in community organizing and leaned heavily on the experience of Lafayette. "[Bernard] took me by the hand," Ouellet related to a reporter, "as though I were in kindergarten and led me to understand community relations." ${ }^{4}$ Unable to dissuade the priest from continuing his activities, city authorities continued their harassment.

Sisters Geck recalled that she would often meet with Father Ouellet after she finished teaching, so that they could discuss mission business. Ouellet's office in the parish hall looked out onto Broad Street. As the children walked home from school, sheriff's deputies would roust them directly in front of the mission in the hopes of drawing the priest out of the mission. Ouellet told Geck, "They are waiting to see what I will do. I can't go out I don't want to give them the satisfaction of arresting me."55 As a result of the harassment Ouellet's own

51 Ouellet Interview. See also: Zinn, Zinn Reader, 78. Zinn mist-identifies Ouellet as "Ouillet" and the mission as the "St. Edmond's" mission

52 John Cogley, "Archbishop Ousts Priests at Selma," New York Times, June26, 1965.

53 Chris Heinz Letter to Thomas J. Toolen, September 23, 1963. ADMA. Box 1963, File "H."

54 Fry, "The Voter Registration Drive in Selma Alabama," 256.

55 Geck Interview. 
commitment was only deepened. He recounted a 1963 trip with another minister to Tuskegee, where the two discussed the very real possibility of being killed:

We were both physically and emotionally tired We both concluded that we couldn't think about that. It would influence what we did and didn't do. The thing was that we were committed and what would happen would happen and there was nothing that we could do to control it. This is what we wanted and what we were committing ourselves to and we would take whatever consequences and with that for me came a lot of peace..$^{56}$

As Ouellet's commitment deepened, tensions began to rise between white and black Catholics in nearby parishes.

As the only white identified with the movement, Ouellet became a likely contact for whites. Ouellet received a phone call from Rex Morthland, president of a local bank and the school board, who wondered if he and Ouellet could arrange a meeting between the two sides. After a number of calls, Northland's plan failed. No whites would agree to meet with the black leadership. He relayed to Ouellet a rumor that he had come across. The moderate business community, like their religious counterparts, was not willing to suffer the retribution of rabid segregationists. Ouellet remembers that supposedly "there was a big stash of guns ... somewhere near a railroad site and that black people were going to get together and that they were going kill everybody." ${ }^{57}$ White fears of a race war created an atmosphere that prevented meaningful discussion, just as much as the intransigence of the city government and DCCC.

56 Ouellet Interview.

57 Ouellet Interview. 
On the same day that Heinz and the city officials were pressuring Ouellet to leave the city, a black Catholic layman, Eddie English and his family were traveling from Mobile to Selma to visit family. When English realized that he was not going to be able to make the Mass at St. Elizabeth's, he decided to attend Mass at the Chapel of the Immaculate Conception in Orrville, a small town fifteen miles from Selma. When he and his family entered the Church the ushers asked them what they wanted. English replied that he and his family only wanted to attend Mass. Again he was asked what he wanted. The ushers refused to seat the family, explaining that they did not want a "racial incident" and that this was their church. English left and, as he had feared, was unable to reach Selma before the Mass at St. Elizabeth's had ended. English wrote to the archbishop and explained what had happened.

Toolen was extremely upset by the incident. The archbishop wrote a letter which he ordered Father Thomas Lorigan, the pastor at Immaculate Conception, to read to the parish the following Sunday. In the short memo, typical of Toolen, he explained that he was in receipt of a letter describing the incident from "a fine colored Catholic from Mobile," and asked: "Will you please tell the people of the Orrville church that it is a Catholic Church and belongs to all our people, and that if such a thing happens again I will close the church." 58 Joseph McHugh, a longtime member of the parish was upset and wrote to Toolen to explain his side of the "unpleasant situation".

58 Thomas J. Toolen Letter to Thomas Lorigan. September 24, 1962. ADMA. Box: 1963 File: "E." 
He noted that there were no black Catholics in the area, and he was convinced that the incident was a planned attempt to integrate the service. McHugh criticized the Father of St. Edmund for contributing to the unrest, asking if they were not "more involved than necessary?" He wondered why Catholics should "rush to the scene and be the knight in shinning armor when the only consequence will be unnecessary ridicule." 59 He refused to turn over his church to "the Fathers of St. Edmund to be used as a headquarters for Martin Luther King, Jr., Roy Wilkens, Shuttlesworth, Shores, etc. to accomplish their purpose by using God's Church and innocent children as an instrument of nine percent of our nation's population in their demands rather than their requests." 60

McHugh, the owner of a cotton gin, also described the difficult position he found himself in as a Southern Catholic. He wrote:

The candle seems to be burning on both ends! For instance, in my business I am having heavy pressures from the Citizens' Council along with the help of the KKK, bankers, etc. If I have to accept integration in our Church from outsiders whose primary purpose is not religion but that of providing gains for the NAACP, I will ultimately be forced out of business. Presently, there are many colored families dependent on the operation of my business for their livelihood. If I am forced to make other plans for MY livelihood, will this be a step forward? Do those who are forcing the issue realize our situation and what are they asking of their own people also?61

Toolen replied to McHugh and repeated his claim that the diocese had never been segregated and that all Catholics were always welcome in any Catholic

\footnotetext{
59 Jospeh McHugh Letter to Thomas J. Toolen. September 29, 1963. ADMA. Box: 1963 File: "Mc."

60 lbid.

61 Ibid.
} 
church. What McHugh did not know was that Toolen knew English

personally. Toolen wrote:

I am shocked that any Catholic should think because a man is colored, his faith is not as good as theirs. This man was not planted, I know him well and he is a fine, exemplary Catholic and very modest. He was very hurt that he missed Mass and that one of his fellow Catholics would turn him away from the church. 62

The archbishop again reiterated his threat to close the church should anyone be refused entrance.

But Toolen sympathized with McHugh's position as both men struggled to reconcile the competing requirements of their Catholic faith and their Southern identity. Toolen counseled:

This is a time of stress and strife as we both know, but God's principles are higher than our natural motives and must be carried out. I am sorry that you feel the way you do because God said, "Love God and Love Your Neighbor" and whether we like it or not, the Negroes are our neighbors. I realize the difficulties in a small town like Orrville because of the hatred in the hearts of so many people in regard to the Negroes. Nevertheless your faith is over and above all these things and if necessary we must suffer for it. ${ }^{63}$

Toolen closed the letter telling McHugh that he too was aware of the difficulties the demonstrations were creating for everyone and agreed that "one of the Edmundite priests" might be responsible for escalating the situation. The archbishop explained to McHugh that both he and Ouellet thought they were acting in the best interests of the Church. "He is doing what he feels is right,"

62 Thomas J. Toolen Letter to McHugh. September 29, 1963.

63 Ibid. 
wrote Toolen, "just as you were doing what was right when you turned this Negro away."64

On September 22, SNCC Chairman John Lewis and Executive Director James Forman arrived in Selma. ${ }^{65}$ A large crowd attended a mass meeting Sunday evening at Tabernacle Baptist church. It was the largest crowd the movement had yet generated. Colonel Al Lingo, head of the Alabama Department of Highway Safety, surrounded the church with his troopers. ${ }^{66}$ On Monday, SNCC led a large demonstration to the federal courthouse building. The commitment on the part of the students served as an example to the adults in Selma and soon led to more involvement on their part in the movement. Of the two hundred demonstrators, 150 were students at Hudson High, Selma's black high school. In the last week of September alone, 300 students were rounded-up by Clark and his posse. 67

Many of the parents refused to let their children participate in the movement. They were concerned, both for their children's safety and for their own well-being. The Citizens' Council targeted parents of children who participated in the movement. Sisters Lum in a letter to her parents in Rochester, described how one family was intimidated by the DCCC:

Mrs. Peterson who works at the hospital was worried sick because her son Lester skipped school to go to the demonstrations His parents have

64 Ibid.

65 John Lewis, Walking with the Wind: A Memoir of the Movement, (New York, Simon \& Shuster, 1998), 234.

66 Ibid, 234.

67 Ibid. 
forbidden him to take part because it could put his father out of

business. His father runs an auto repair shop next to his home. Inez said that a white man came to see them to say every child who is arrested will have his family investigated and they will either lose their jobs or be put out of business. He told them "we know your boys."68

But it was a random and unnecessarily aggressive move on Clark's part that brought Selma's black community together.

Clark had heard that the students were planning to march downtown. As the children walked home from school, he arrested 60-75 children. The children were not taken to jail, but to work camps in the surrounding counties. Locals referred to the facility Clark used to hold demonstrators as "Camp Selma." Students were packed into stark, barracks-style buildings. John Lewis described the buildings as little more than chicken coups, with concrete floors, a toilet, a sink and filthy mattresses thrown on the floor. ${ }^{69}$ Ouellet spent a number of days trying to locate the children who had been arrested. Within a few days, lawyers arranged bail for the children, some of whom were as young as ten. Parents were not allowed to see their children.

Ouellet and a few of the Sisters attempted to visit the camp. He wanted to check on their condition, reassure them and bring food. Sisters Alonzo was told that the deputies would bring the food to the prisoners. It had been reported by some of the children held at the camp that the deputies had mixed sand in with some of the food earlier in the day. She demanded the right personally to bring the peanut butter and jelly sandwiches the group had brought with them. The

68 Barbara Lum Letter to Parents. September 18, 1963. Author's collection. 
guards refused and the group left without handing over the food. Sisters

Geck recalled what has been described as "the look" activists often received from

whites. She remembered:

You hear these things but I never really knew what hate was in the eyes of a person until I saw the eyes of the guard up in the tower giving us permission to drive out, you hear it or see it in movies, but to actually see it 70

The incident solidified the support of the adults in the community, Ouellet recalled.

A lot of people in the community who had not come out to mass meetings before suddenly were there - the fact that their kids were endangered, and publicly so, really galvanized them and that really put them behind us I still remember that meeting, all the kids were together, and they all came marching in. You could just feel the resolve and that is when the ministers who had been in the background before, teachers, principals, professional blacks for the first time the black community as a whole was saying things need to change. That had not happened before '63.71

Mass meetings were held at Brown's Chapel, First Baptist and Tabernacle Baptist in response to the arrests. Attendance soared from a few hundred to almost a thousand.

John Lewis was slated to speak at the third mass meeting held at Tabernacle, but at the last minute was unable to attend. He asked Father Ouellet if he would speak in his stead. While Ouellet and the fathers had attended most of the mass meetings, none had spoken publicly. Ouellet began his speech by defending his right to be involved in the movement on scriptural

69 Lewis, Walking with the Wind, 234.

70 Mary Paul Geck Interview by author (March 2, 2001).

71 Ouellet Interview . 
grounds. He responded to those who argued that he "mind his own

business. "Recalling the parable of the fishes and loaves, he pointed out that Jesus instructed his apostles to be concerned with the practical welfare of His people. ${ }^{72}$ Jesus instructed Peter to "Feed my lambs and feed my sheep."

Ouellet explained:

He did not tell Peter how his lambs and sheep should be fed; he did not tell Peter to go forth and build a church and concern himself with purely spiritual matters of his people, rather our Lord very simply entrusted to him the care of his flock. I firmly believe that it is the duty of any religious leader to perform this duty in whatever manner he can. He is limited to no particular sphere. He must look to the welfare of his people and this will carry him into many diversified areas. ${ }^{73}$

This concern for the welfare of the people, he noted, was not a recent invention. It was rooted in a strong tradition of Catholic social and political involvement. He pointed to the encyclicals of Popes Leo XIII and Pius XI on the rights of the workingman, and most recently the work of John XXIII and the Second Vatican Council. ${ }^{74}$ Speaking specifically of voting rights, Ouellet declared that, "In this instance, we are generally concerned with the fundamental rights of men as created by God."75

Having established his responsibility to participate in the movement as a Catholic priest, Ouellet declared that he also had a right and an obligation to speak as an American citizen saying:

\footnotetext{
72 Maurice Ouellet, "Mass Meeting Address," July, 1963, 1, 2. ARC. Ouellet Papers. Box 1, Folder 1.

$73 \mathrm{lbid}, 2$.

74 Leo XIII's encyclical Rerum Novarum, Pius XIII Quadregisimo Ano, and John XXIII convened the Second Vatican Council.,
} 
I, therefore, as a citizen of the United States, resident of the State of Alabama, of the City of Selma, do proclaim my right to speak, as is my right, for the equality of all mankind. I do not stand against something, I stand for something, namely, the freedom to proclaim men free. ${ }^{76}$

As Americans, Ouellet explained, everyone had a duty to fight for freedom and justice. He equated the present struggle for freedom with World War II. As a young seminarian during the war, he admitted feeling that he was somehow avoiding his responsibility. He told the crowd that he considered leaving the seminary to join the service and how he wrote to his brother in the Navy for advice. His brother pointed out to him that if he joined the war effort, he would be serving among millions of men, and that his contribution would be diluted. However, if he remained in school and became a priest, he "might someday be able to lead men in a time when there would exist possibly even greater need." 77 That time of great need, Ouellet believed, was the present. He told the assembly that his brother was dead and "buried beneath an American Flag." "I am sincerely convinced," he said, "that I cannot be unwilling to pay a lesser price than he did."78

Ouellet then chastised the black leadership. Noting that many of the important members of the community were not in attendance, He declared that the failure of the community to come together was the fault of the black leadership. While he and the mission had clearly identified themselves with the

\footnotetext{
75 Ouellet, "Mass Meeting Address," 2.

$76 \mathrm{lbid}, 2$.

77 Ibid, 3.

78 Ibid.
} 
black community, as a white man and a Catholic, he stood outside of the black power structure. Those leaders were black and Protestant. Without naming names, the priest recalled that many of those leaders had questioned his motives for working among blacks. He asked where were they when their community needed them? He requested that these leaders display the kind of courage that the children had demonstrated, and he appealed to them to "cease being afraid, to show the people the way ... nonviolently, in accordance with the law."79

Even though he recognized that they would think his request "ridiculous," Ouellet called upon the whites to put away their fears and to address constructively the concerns the black community had raised. He asked whites to stop hoping that this situation would simply "go away" and specifically charged white religious leaders to "lead their people in love of God and in love of their neighbor." 80 From the black community, he asked for courtesy and good manners and pleaded that they maintain nonviolent discipline and put aside notions of revenge and retaliation.

Ouellet then pointed out that no one had yet acknowledged the work that Bernard Lafayette had done. He said:

I personally feel that I owe him a great deal. Though he is younger in years than I, he has taught me much. I believe he deserves a great deal of credit because he was willing to stand up alone, and this is not easy. I think this community owes him a debt that it can never repay. I consider him to be a man of conviction and, therefore, a very holy man. And certainly it would be

79 Ibid, 5.

80 lbid. 
a shame if the people of Selma repaid his dedication to them with a lack of conviction, such as has been manifested by the leaders of this community. ${ }^{81}$

As a Christian, Ouellet declared, "the greatest sin lies in the soul of a man who loves God and hates his neighbor." Therefore every member of the community, white and black, had a moral obligation to participate in the movement to end segregation and secure the rights of all citizens.

While many, in both the Mission and the community, were proud of Ouellet's speaking out, some were not. The next day, one of his parishioners came up to him and warned him saying, "Father, don't do that. I have been here a long time and you can't do that stuff around here. You can't do what you did last night."82 Ouellet continued to speak out. Every Sunday, Ouellet addressed the injustices the community faced and the Christian means that might enable them to overcome those injustices. He recalled:

I constantly included in Sunday homilies references to what was going on and what our Christian duty was. That we had an obligation before God to vote If we are going to be good citizens we certainly had to [vote]. I stressed Dr. King's idea of redemptive suffering Possibly we wouldn't bring about all the changes that we wanted, but that there was something redemptive in the fact that we were willing to suffer for this, and that someday it would be worthwhile. 83

The support of the Fathers and the Sisters was an inspiration to those who were involved and an example to those who were not. Parishioner Robert "Shooty" Craig was employed by the Fathers as a handyman, doing small carpentry work

$81 \mathrm{lbid}, 6$.

82 Ouellet Interview.

83 Ouellet Interview. 
around the mission. He recalled that Ouellet did a great deal for the confidence of those who chose to be active. He said:

It was a star in his crown when his congregation looked and saw him participating, especially in what most now call a "black thing." Talking against segregation. It made you feel good when you were sitting there on Sunday that here was somebody on your side, even though he was a different color. ${ }^{84}$

Numerous members of the congregation, as well as the hospital and mission staff, were involved in the movement. While Craig pointed out that he did not march during the movement as he felt he would be unable to refrain from retaliating if assaulted, he did assist in other ways. ${ }^{85}$ He recalled the support of the Fathers. Ouellet told Craig that he could leave whenever he wanted if the movement needed him.

${ }^{84}$ Robert Craig Interview by author (March 18, 1994). Note: Craig's nickname, "Shooty" refers to his propensity for always shooting the ball while playing for the Don Bosco Boy Club basketball team as a child.

85 Craig Interview. 


\section{Chapter 7 :"Peace Rather than Strife.”}

I think that it is the duty of all of us to try to bring peace rather than strife. We know that by the colored going to Assumption Church we shall have strife."

Archbishop Thomas J. Toolen

Early in 1964, Father John Crowley, S.S.E. arrived in Selma and replaced Father Galligan as Director of the Edmundites' Southern Missions. Galligan had been recently elected Superior General of the Society of St. Edmund and was returning to Vermont. Crowley was aware of Ouellet's activities and supported him in those efforts. He suggested that Ouellet meet with Archbishop Toolen to detail his involvement in the movement. Ouellet was convinced that none of his activities to this point warranted the archbishop's approval, but agreed with Crowley that it would be best to keep the archbishop informed of his activities. ${ }^{1}$ This was particularly important since Toolen had been getting pressure from state and local authorities complaining of the priest's activities.

Mayor Heinz had written to Toolen detailing his meetings with Ouellet and Galligan. He noted that his delegation had strongly recommended to Galligan "some curtailment" of Ouellet's activities "in the open advocacy and latent activity of public defiance of the law." 2 He enclosed the letter Ouellet had written to the local paper following his failed DCCMU meeting. The mayor explained:

I feel that I speak the opinion of the intelligent Catholic community, as well as law enforcement authorities, and the Protestants of Selma, when I say

\footnotetext{
${ }^{1}$ Fry, "The Voter Registration Drive in Selma Alabama," 261

2 Heinz Heinz Letter to Toolen.
} 
that the continued presence of the Rev. Ouellet is detrimental to the public relations of the Catholic community and may also involve the personal safety of this priest. The white people have shown a remarkable restraint in the crisis through which we are passing in Selma. We have dealt severely with the hooligan element, which would make capital of this situation and we are doing everything possible to preserve peace and order here, but it is my opinion that open defiance, on the part of any of the clergy, creates an impossible situation. ${ }^{3}$

Ouellet and Crowley met with Toolen at the archbishop's residence in Mobile.

Ouellet explained that his activities dealt mainly with voter registration, and that the parish hall was being used for voter registration and literacy classes. "We certainly ought to be helping people to exercise a right which was theirs by the Constitution," Toolen said, " so long as legal processes were observed. ${ }^{4}$ But he had serious reservations about the willingness of Southern whites to stand by and let blacks register without resorting to violence. With the unpunished murder of Father Coyle in 1921 on his mind, the archbishop instructed Ouellet that he could continue his work, but under no circumstances could he march.

Ouellet argued that it would be very difficult to continue his efforts and yet be restricted from marching. How could he ask his parishioners to march and not go with them? Toolen countered:

I don't want a dead priest in my diocese. I don't want you marching. You can help out in this, do what you can in this, but I don't want you marching." 5 Toolen extended the order to all Fathers and Sisters of the Mission. Henry Cabriac, Southern Field Secretary for the NCCIJ, visited Selma in early

\footnotetext{
3 lbid.

4 Ouellet Interview.

5 lbid.
} 
December 1963 and noted that while Toolen had been pressured by both Wallace and Heinz to remove Ouellet, he had denied both requests. Cabriac wryly noted that, "this isn't any indication that he is favorable to what Father Ouellet is doing, but is more unfavorable to non-Catholics trying to run his Church for him." 6 Cabriac reported that many felt that Ouellet had mishandled the situation in Selma and that the only reason Ouellet apparently was allowed to remain in Selma was due to the good relationship he had with his superior. ${ }^{7}$

Ouellet never questioned the archbishop, and he and the other men and women religious in Selma abided by the order. They were quickly told of the archbishop's stance. Sisters Lum recalled that:

[Toolen] was very fearful of losing the financial support of the white Catholics in Alabama. He had visions of the Church losing the small foothold that it already had . . . but he wasn't seeing the injustice and the opportunity. ${ }^{8}$

The sisters and fathers agreed that the best course of action would be to concentrate on the mission. Sisters Lum noted that most of the priests and sisters felt that "this was a time to focus on our mission at the hospital." 9 Sisters Geck recalled that some of the priests wanted to march and to participate more fully in the demonstrations. She noted:

I remember that Father McNeice just begged to march. He was just three years ordained ... . He just wanted to get in and Ouellet said no because the

\footnotetext{
6 Henry Cabriac Letter to Matthew Ahmann. (December 17 \& 18, 1963), NCCIJ Papers MUA. Ahmann Correspondence.

7 lbid.

8 Lum Interview

9 Ibid.
} 
Archbishop has said if you or the Sisters march you will be out of Alabama on the next train. ${ }^{10}$

Father Ouellet told his assistant pastor, "It will mean the death of everything we've done."11

The involvement of St. Elizabeth's with the AVRP was beginning to strain the already tense relationship between the mission and Our Lady of the Assumption. Blacks occasionally attended Mass at Assumption, but interracial worship was not something white Catholics were willing to tolerate any longer. Black militancy now demanded a determined white response. In late June, after three black Catholics attended Mass there, they were attacked by a small group of parishioners who cursed, chased and threw stones at them. The three blacks escaped, although their attackers continued looking for them in a nearby black neighborhood for some time.

The following week, Assumption placed a sign marked "Visitors" on the back pew. Ouellet wrote to Toolen to report the incident:

Your Excellency, I am taking it upon myself to report two facts which have been reported to me. My purpose is not to criticize or ask for action on these facts. I simply wish to state these as they were told to me, realizing that any decision in respect to them is in your hands It is no exaggeration to say that Negroes feel they are not welcome at Assumption church. ${ }^{12}$

Toolen began to lose patience with all parties in Selma. His response to Ouellet is the clearest indication he gave as to how to he felt the situation should be handled. The

\footnotetext{
10 Geck Interview.

11 Patricia Creighton, "What were you doing in Selma, Sisters?," (B.A. Thesis, State University of New York at Purchase, Department of History, 1992)
} 
archbishop noted that he had requested an explanation from the pastor of Assumption, and chastised Ouellet for failing to "quell the disturbances." He then asserted:

We know these Negroes go to the Church for no other purpose than to stir up trouble. We have fought for them and tried to make known to them that they are welcome in any Catholic church, but not much has been done to urge them to attend their own Church. They are really members of St. Elizabeth's. I feel sure that they know they are not welcome by the people of Assumption church, but are welcome at the Church itself, and we cannot control all the people of any parish, even yours. ${ }^{13}$

Toolen admitted that it was unfortunate that the incident had occurred, but recognized that the present racial strife was not going to go away anytime soon and other similar incidents were more than likely to occur in the future. Therefore, Toolen lectured Ouellet, "I think that it is the duty of all of us to try to bring peace rather than strife. We know that by the colored going to Assumption Church we shall have strife."14 The distinction Toolen makes between the Church as a whole and the particular manifestations of that Church in a particular society is crucial to understanding his rationale for working within the confines of Jim Crow. Toolen believed that progress had to occur without discord. Conflict not only made progress less likely, but threatened to undermine recent gains.

Despite Toolen's intervention, there was another incident at Assumption a few months later that deeply disturbed the Archbishop and gave further credence to his fear of escalating violence. Air Force Sgt. James Burke, a World War II

\footnotetext{
12 Maurice Ouellet to Thomas Toolen. March 3, 1964. Amistad Center. Ouellet Papers. Box 1 Folder 12.

13 Ibid.
} 
veteran, had been stationed at Craig Air Force Base since January. He had moved into town with his family, rather than live on the base. Burke mentioned to a neighbor that he was Catholic. The neighbor insisted "there were two Catholic Churches in Selma, one white and one 'nigger."' He then advised Burke to be sure to attend the white one. Burke replied that:

There was but one Catholic Church, the universal Catholic Church for every race and every color, and that I had never known anywhere where they had a separate church for the colored people. ${ }^{15}$

The neighbor insisted that it was not a colored church but a "nigger" church and warned Burke to watch his step. Burke recalled that the racial tension in the city made him feel as if he were "living in a foreign country." 16 However, no other incidents occurred until October.

On Sunday, October 4, 1964, Burke attended the 10 am Mass at Assumption with his two young sons. A small group of African American teenagers sat in the back during the Mass. A few of the black children attended mass at Assumption regularly, others had begun coming only recently, mostly as an outgrowth of the demonstrations..$^{17}$ Someone in the congregation became incensed at their presence and attempted to force the children to leave. Burke stated that he saw:

One of the regular [parishioners] twist and pull one of the colored boy's ears. After Mass had ended and the congregation filed out, my sons and I proceeded to our car; as I reached it, I heard someone scream, and turning

\footnotetext{
14 Ibid.

15 "Srgt. James Burke, Jr. USAF," Jubilee, August 1965, 18

16 Ibid.

17 Longenecker, Selma's Peacemaker, 116.
} 
around I saw three white men beating two little colored boys. They had knocked them down and were kicking them. ${ }^{18}$

Burke ran to the aid of the children. When he went to discuss the matter with the parish priest, Father Charles Aucoin, he "saw in his eyes the same fear that I had seen so many times before."19 Later Aucoin asked Burke not to attend Mass at Assumption, but at Craig Air Force Base.

Within days the Burke family began to receive threatening phone calls at their house. On October 11, while at Mass at Assumption, Burke's car was vandalized. Local police and the FBI refused to investigate. Burke took to keeping guns in his house and carrying one with him when he was not on the base. The harassment culminated on the 19th of December. Burke had just returned home from Christmas shopping when two men knocked at his door claiming to have accidentally backed into his car on the street. As he was examining his car, two more men appeared and they began to beat him, one with a blackjack. He testified that, "During the fighting, these men who I had never seen before, kept telling me not to go to church with niggers; they called me a goddamn nigger lover, and said they would kill me."20 Burke's son dispersed the attackers with a number of shots from a rifle, hitting one of them. Burke suffered severe bruises all over his body, numerous stitches, and had both eyes swell shut. His back was permanently damaged. None of his neighbors came to his defense or aid.

18 "Sgt. James Burke, Jr. USAF," Jubilee, August 1965, 18.

19 lbid. 
Aucoin reported the incidents to Archbishop Toolen. He stated that the attack on the children was "brought about by these colored men occupying a separate pew in Church, and refusing to budge to allow anyone easy entrance." The assault on Burke, the priest declared:

Was and, purely is, a police matter, which the Selma police department is handling extremely well. There may be overtones to the integration problem, since the thugs who attacked Sgt. Burke are supposed to have made remarks about his integrationist views while they were beating him up in front of his home. ${ }^{21}$

The Selma police department did act swiftly to resolve the matter. Three men were arrested later that night, while the fourth was arrested in Montgomery a few days later. The men took Burke's wallet, which contained three hundred dollars, and so the case was being treated by authorities as a robbery.

Not all of Selma's white Catholics dismissed the "overtones" of the incident. One concerned Catholic citizen, Mrs. M.B. Tidwell of Selma, did write Bishop Toolen about the affair in order to express her concern and shock at the behavior of her fellow parishioners. Toolen's response is indicative of his sense that events were beginning to spiral out of control and his wish to hold back Catholic involvement for fear of real damage being done to the Church. He wrote:

I believe that the Church has done about all it can do in Selma. We have taken the stand that no one shall be refused entrance into our Church or taking part of the services of our Church. It seems to me that it is the work of the police department, which is not too favorable, but there is the U.S.

20 Burke, "Frightening Case," 20.

21 Charles Aucoin Letter to Thomas Toolen. January 2, 1965. ADMA. Box 1965 File "Assumption, Selma." 
Armed Forces, which should take care of their people. We should cooperate in every way but it is their obligation, not ours. ${ }^{22}$

Burke later transferred to an Air Force base in Texas, and soon retired from the military as a result of injuries he sustained in the attack. ${ }^{23}$ As far as Toolen was concerned, the events of the past year had exceeded his worst fears.

Gradualism had given way to violent confrontation.

As the Burke incident unfolded, the AVRP escalated demonstrations at the courthouse. Organizers declared Monday, October 7, 1963, "Freedom Day" and, for the first time since the demonstrations began, national attention was focused on Selma. ${ }^{24}$ Members of the national media, federal observers from the FBI and Justice Department, came to Selma, as well as celebrities such as Dick Gregory. ${ }^{25}$ High school students canvassed the city that week and posted numerous fliers informing the community that the courthouse would be open on Monday for registration. On Sunday, October 6, James Foreman addressed the mass meeting and declared:

All right, let's go through the phone book. You'll know who's Negro, because they won't have Mr. or Mrs. in front of their names! You got to get on the phone tonight and call these people and tell them to come down to the courthouse tomorrow and register tomorrow You take a bologna sandwich and a cool glass of water and stay there all day. Now get on that phone tonight. Who'll take the "A"s?26

22 Thomas J. Toolen Letter to M.B. Tidwell. January 9, 1964, ADMA. Box 1965 File 'T'

23 Ibid.

24 Powledge, Free at Last?, 613.

25 Zinn, Zinn Reader, 79

$26 \mathrm{Ibid}, 81$ 
A sign on the podium read "Do You Want to Be Free?"27

That Monday, 350 African Americans marched to the courthouse and stood in line for eight hours to register. The line of African American applicants stretched from the courthouse steps, along the building and into the side alley. Clark and his posse were positioned on the steps and along the street. Foreman asked some SNCC staffers to procure food and water for the people waiting in line. Around noon a large contingent of Alabama State Troopers arrived. While the County registrars took a two-hour lunch break, those standing in line began to wither from the heat. No one had been allowed to bring food or water, and Foreman feared that if they left, they would not be allowed or might not want to return.

Foreman asked Clark if he could bring those in line something to eat. Clark retorted, "They will not be molested in any way, if you do you'll be arrested." Howard Zinn, professor at Spellman College and senior consultant to SNCC, spoke with a senior Justice Department official whether or not he might attempt to negotiate a settlement. While the official acknowledged that those in line were entitled to food and water, he refused to speak with Clark on their behalf. With no other alternative, SNCC staffers Avery Williams and Chico Neblett crossed the street and attempted to deliver sandwiches to those in line. As they approached the line, they were attacked by state troopers with billy clubs 
and cattle prods. ${ }^{28}$ Members of the news media were assaulted and had their cameras or film confiscated during the assault. That day six people were arrested, while the registrar processed only fourteen people.

Sisters Barbara Lum recounted the week's events to her parents in Rochester:

Monday was 'Freedom Day' in Selma. Every Negro was encouraged to go downtown and register to vote. A large number went and stood all day waiting for the line to move. A small number got in The mass meeting Monday night was next door to us. Of course we watched and listened all we could in the dark. They filled the gallery which we never even saw people use before. We couldn't hear the speakers but the Freedom songs were sung beautifully and with vigor. ${ }^{29}$

Both Ouellet and McNeice attended the mass meeting. ${ }^{30}$ The next morning a full-page newspaper advertisement responded to "Freedom Day" by proclaiming that peace and tranquility existed between the races in Selma. The advertisement blamed outside agitators for the recent unrest. ${ }^{31}$

Earlier that Fall, in the hopes of putting even more pressure on Selma's business community, SNCC tried to have Air Force personnel at Craig Air Force Base restricted from the city. Worth Long met with Colonel Richard Ault and requested the Air Force bar its personnel at Craig from entering the city due to the "gross discrimination practiced against Negroes." Ault denied the alleged discrimination was directed towards citizens and not servicemen. SNCC

\footnotetext{
28 "Freedom Monday" account in Ibid, 80-90. See also Lewis, Walking with the Wind, 235, Fry, "The Voter Registration Drive," 251.

29 Barbara Lum Letter to Parents. October 9, 1963. Author's collection.

30 Zinn, Zinn Reader, 89-90

31 Powledge, Free at Last?, 613.
} 
continued to press the issue, without success throughout 1964.32 While the number of demonstrations and the level of participation were increasing, the AVRP began to run out of bail money. ${ }^{33}$ Organizers shifted away from demonstrations and concentrated instead on a Christmas boycott. The theme of the boycott was "Don't Buy Segregation." ${ }^{4}$ The boycott posed a serious logistical problem for black Selmians, the Mission and the hospital, as it required them to drive to Montgomery and Birmingham for supplies. ${ }^{35}$ The boycott, though not a complete success, was by no means a failure and continued through the spring. The white power structure, while relieved that the demonstrations had ceased, was disgruntled about being on the receiving end of economic retaliation. The DCCC increased its efforts to identify, pressure and intimidate movement participants. A number of women who had marched on “Freedom Day" were fired and blacklisted by the Citizens' Council when their employer spotted them in line. ${ }^{36}$

As the demonstrations wound down and the boycott began, the city's struggles with civil rights were overshadowed in late November by events in Dallas. The reaction to the assassination of President Kennedy demonstrated the vast gulf that separated those on both sides of the city. News of the assassination touched off a celebration among whites that lasted well into the

\footnotetext{
32 John Love letter to Robert McNamara. December 23, 1964. RSP (Microfiche Reel 3) See also: Lewis Walking with the Wind. 233

33 Longenecker, Selma's Peacemaker, 50

34 Ibid, 51.

35 Geck Interview.
} 
evening. ${ }^{37}$ For Southern whites, Kennedy possessed all the qualities they despised-he was a Yankee, a Catholic, an integrationist, and he had the audacity to try and interfere with what was clearly a local matter. For Catholics, Kennedy's election three years earlier had signaled a profound shift in the status quo. That a Catholic could be elected to the nation's highest office had seemed impossible only a few years earlier. At St. Elizabeth's the children and staff were devastated. Sisters and students cried upon hearing the news of the President's death. Sisters Geck gathered the entire school together and led students and teachers in the rosary. However, the reaction of children at the white Catholic school in town was markedly different. One of the Sisters of Mercy who taught at Assumption's school explained to Geck that her Catholic students cheered when they were told that the President was dead. ${ }^{38}$ The Sisters was visibly shaken by the reaction of her children and appeared for the first time to confront the depth of racism that existed in the South. ${ }^{39}$

All of the Sisters planned to vote in the 1964 presidential election. Sisters Geck went down to the courthouse to pay the poll tax. She explained to the registrar that she wanted to pay for all of the Sisters who were registered. She asked for the total amount she owed, but it seemed to her the figure the man gave her was too low. After questioning the official a number of times, she left with her receipt. When Geck went to vote, she was given the national ballot but

\footnotetext{
36 Fager, Selma:1965, 44. The woman worked in the Dunn Rest Home in Selma.

37 Longenecker, Selma's Peacemaker, 39.

38 Geck Interview.
} 
not the local ballot. She also remembered that the national ballot did not have President Johnson's name on it, but "Democratic Candidate" instead. Incensed, she argued with the voting officials, and eventually drove to the courthouse to seek out a Judge. Most of the staff had gone home for the evening, but she was able to catch Judge Reynolds' secretary before she left. She explained what had happened, and refused to leave until the matter was resolved. As the Sisters stood over her desk, the secretary called Reynolds at his home and explained the situation to him. Realizing that if she could hear what the Judge was saying, he might be able to hear her, Geck began loudly demanding a full ballot. 40 Judge Reynolds relented and issued an order authorizing her access to a full ballot. However, Geck was very aware that her ability to vote was tied inextricably to her race. That evening while relating the incident to the other Sisters, she said "but you know if I had been a black person, I would have been slapped in jail."41

Other Sisters had to overcome less sinister but equally frustrating obstacles in order to vote. Sisters Virginia during her interview by the Board of Registrars was asked if she would serve in the armed forces. After some thought, she answered that as a Catholic Sisters she could not serve in the military. She was rejected but did not receive notification until it was too late to appeal the decision. Nor did the notice clarify the reason for the rejection. Sisters Virginia compared 
her answers with those of Sisters Geck and came to the conclusion that her refusal to serve in the military was the reason for her disqualification. Sisters Geck recalled that the only way she was able to answer the written questions on the Alabama constitution was that she had taught the required curriculum on Alabama history to her eighth graders earlier that year. ${ }^{42}$

That year Selma's incumbent mayor, Mayor Heinz, was defeated by a young brash politician, Joseph Smitherman. Smitherman was the antithesis of Heinz. His father had abandoned the family when he was young, and his mother had died shortly afterwards. He had essentially raised himself. After graduating from high school, he become a partner in a successful home appliance store. Smitherman was elected to the city council in 1960 , and championed a number of municipal improvements including street paving and sewer construction. In 1962 he organized a group of businessmen, the Committee of 100 , who sought to attract new industry to the area in order to diversify the economy. The group was made up of younger business men, many who had recently moved to Selma, and were a direct challenge to Selma's ruling class..$^{43}$ Smitherman and the city's business community realized that in order to do this, they would have to avoid bad publicity. 44

The 1964 mayoral race was the first won by a non-Burns-machine candidate in 31 years. Smitherman ran on a progressive platform that stressed

42 Ibid.

43 Robert Scott Hereford, "A Study of Selma and Dallas County, Alabama, 1930-1970," (M.A. Thesis: University of Georgia, 1989), 80-91. 
municipal improvements, professional law enforcement and industrial

development. He also promised to break up the Burns machine. "For 30 years a favored few have dominated Selma and have tried to do your thinking for you!" Smitherman asked, "Are you satisfied with Selma's progress under their control? Or do you agree that after 30 years it's time for a change?"45 While the new mayor was not a member of the Democratic Party, DCCC, or the city's business elite, he did support segregation, but he promised to rein in Sheriff Clark and his posse. The black community supported Smitherman, and almost all of the city's black voters cast their ballots for him in the election. Those 200 votes made up almost half of Smitherman's margin of victory. Amelia Boynton apparently considered running for mayor but decided against it for fear of splitting the vote and weakening Smitherman's chances. ${ }^{46}$

Smitherman did not take office for seven months after the election, and just as the city was reevaluating its commitment to segregation and the best means of preserving it, SNCC began to view Selma as a test of its ability to organize in Alabama. The AVRP had not achieved any substantial victories; few new voters had been added to the rolls and Clark's constant harassment was beginning to take an emotional and financial toll on the AVRP staff and volunteers. SNCC began to invest a larger share of its resources in the

\footnotetext{
44 Ibid, 54-59. See also Fager, Selma, 1965, 6 and Fitts, Selma: Queen City of the South, 135. $45 \mathrm{~J}$. Mills Thornton, "Municipal Politics and the Course of the Movement," in New Directions in Civil Rights Studies. Eds. Armstead Robinson and Patricia Robinson (Charlottesville, University Press of Virginia, 1991), 38-64, 55. Cf. Selma Times Journal, February 2, 1964. 46 Ibid, 57.
} 
campaign. As the SNCC presence increased in the city, more and more arrests were made.

On July 4, 1964, SNCC and SCLC tested theaters, restaurants, and hotels throughout the state for compliance with the newly enacted Civil Rights Law that President Johnson had signed into law two days earlier. ${ }^{47}$ Unexpectedly, they found that in most cities merchants were complying with the new legislation. In fact, compliance was so widespread that SCLC concluded that no concerted campaign could be mounted in Alabama around the issue of desegregation. 48 To no one's surprise, Selma proved to be the exception. AVRP teams tested the city's two movie theaters, the Wilby and the Walton, and a number of local restaurants. On Saturday, police were called to both theaters and a number of restaurants. Nonviolent discipline broke down and scuffles occurred on a number of occasions, as tensions quickly escalated between activists and onlookers. The next day a riot erupted outside a SNCC mass meeting. Clark and his men were called to the scene after a shot was fired and bricks and bottles were thrown. Clark broke up the melee with tear gas and billy clubs. He declared, "I hate to think what would have happened if the posse hadn't been on hand." 49

Ouellet had been out of town on a much-needed vacation. When he returned, he counseled patience and restraint, but the situation continued to

47 Longenecker, Selma's Peacemaker, 79.

48 David Garrow, Bearing the Cross: Martin Luther King Jr. and The Southern Christian Leadership Conference, (New York, Vintage, 1986), 339-340. 
deteriorate and his pleas fell upon deaf ears. ${ }^{50}$ Tensions were running high and proved to be too much for the ALP summer volunteers. The pressure of working underground in a small town led them to a breaking point. All four ALP staffers blew their cover that weekend by participating in the testing at the Thirsty Boy. ${ }^{51}$ Varela, who had not been identified by the police as a SNCC activist, was forced to go and bail her staff out. She remembered:

Screwing up my courage, I put on my most feminine summer dress and went down to the jail to get them out. Because the SNCC and St. Elizabeth staffs had so effectively protected my presence in Selma, the cops didn't know me or what to do about my request for information on getting bail. It was a holiday and impossible to get anything done. ${ }^{52}$

Eventually Varela was able to secure the release of her staff. But the arrests effectively ended the Alabama Literacy Project. Having compromised their anonymity, the ALP staff became targets of Clark and his posse. Writing about the events years later, Varela concluded that:

Testing the literacy programs on a small basis blew up because it didn't matter to the racists whether we stood in their face in demonstrations or quietly tutored someone to read. All of our actions were assaults on apartheid. Our attempts at creating an orderly, sequential way of challenging the literacy tests disintegrated. ${ }^{53}$

Educating potential voters, holding demonstrations at the courthouse, or staging sit ins at a local business were all equally unacceptable challenges to the status quo. By the end of the summer all but one ALP staff member returned home.

49 Longenecker, Selma's Peacemaker, 80-1.

$50 \mathrm{lbid}, 81$ and 93.

51 Powledge, Free at Last?, 621 and Longenecker, Selma's Peacemaker, 79.

52 Varela, My Sixties, 11.

$53 \mathrm{lbid}, 11$ 
Silas Norman became a full-time SNCC staff member, and was eventually named the Alabama Project Director for SNCC. ${ }^{54}$

Selma was becoming the flashpoint for all civil rights battles in the state which prompted some of the more volatile elements of the pro-segregation forces to move into the city. On July 8 , the Klan, the American Nazi Party and the National States Rights Party sent groups to Selma, and a number of fights with movement supporters broke out. The city was a powder keg and neither Clark nor the DCCC were able to control the pro-segregation forces. Fearing a serious outbreak of violence and wanting to curtail further protests, Circuit Court Judge James Hare issued an injunction on July 9, 1964.55 The order was nothing short of a universal ban on all civil rights activity, pro or con. The injunction prohibited assembly of three persons or more in a public place or from meeting with any of the 41 civil rights activists he named in the petition.

Just as the AVRP was facing its first major setback, SCLC staff members James Bevel and Dianne Nash were beginning to build support for a plan that they had devised a few years earlier. In 1963 after they had learned of the bombing at the 16 th Street Church, both were shaken and resolved to end segregation in Alabama. The plan called for the creation of a "nonviolent army" that would be sent into Montgomery, and through the use of direct-action protests, call-ins, sit-ins and strikes, paralyze the city. The ultimate goal of the

54 Powledge, Free at Last?, 622.

55 Fager, Selma 1965, 5. 
plan was the removal of Governor Wallace from office and the registration to vote of every Alabama citizen over the age of twenty-one.

Bevel and Nash presented "A Proposal for Action in Montgomery" to King and the rest of the SCLC senior staff at a meeting on September 18, 1963 in Birmingham. He envisioned high school and college students providing most of the manpower. Large-scale demonstrations throughout the state, heavily focused on particular localities were to be initiated. Widespread action would divide the government's forces over a large area, thus limiting their ability to interfere with the movement. Also, indigenous leadership would be developed statewide. At the same time, a more concentrated approach would enable the news media more effectively to cover the demonstrations should violence occur. Also, nonviolent discipline would be easier to maintain due to the concentration of well-trained organizers. In either case, the resulting pressure placed on the state and local governments would probably lead to violence and the resulting media attention would help SCLC to pressure the state and federal governments to change the voting laws. "The most important thing in this battle," Bevel claimed, "is to actually see that obstacles are removed and to get large numbers of Negroes in Alabama registered." 56

King was bemused by the plan. SCLC member Rev. John Thomas Porter remembers that King "looked at [Nash] and laughed because she suggested

56 Ibid, 315. 
that we go out and throw ourselves under trains and the wheels of airplanes."57 The plan was shelved, but the Bevels continued to lobby for support of the idea. A month later, on October 15, 1963, King came to Selma to speak at a rally. Amelia Boynton had extended the invitation on behalf of the DCVL. Bevel was impressed with the progress that SNCC had made and pondered making Selma the focus of his plans. ${ }^{58}$ However, the movement in Birmingham precluded any immediate SCLC move into the city. That did not stop the local authorities from taking notice. They discovered that Thelton Henderson, a young lawyer for the Justice Department, had lent his rental car to a local pastor, Nelson Smith. Smith was scheduled to drive King to the airport in Montgomery, but his car had a flat. When it came to light that the car driving King was from the Justice Department, the segregationists seized upon the fact as proof that the government was part of a conspiracy with the civil rights activists. The city convened a grand jury to investigate and threatened to subpoena top Justice Department officials. As the scandal unfolded, Henderson was forced to resign his position. 59

Bevel continued to press for a prolonged nonviolent campaign that "would lead to the education and enfranchisement of nearly all people in Alabama."60 In February he resubmitted his plan to the SCLC leadership. This time King was

\footnotetext{
57 Garrow, Bearing the Cross, 293-294

58 Ibid, 301

59 Thelton Henderson, "An Interview with Thelton Henderson," in We Shall Overcome Anthology, 407. See also Garrow, Bearing the Cross, 306

60 "Program for Action in Alabama" cited in Garrow, Bearing the Cross, 314.
} 
more receptive to the plan, and he eventually endorsed it. At the March 4, 1964, SCLC Affiliates meeting in Montgomery, King announced he was adopting a five-point plan:

1. Intensification of voter registration efforts.

2. Initiation of a state-wide coordination of [the] masses in direct action to secure in fact the right of the ballot" by employing whatever techniques are necessary to implement one man-one vote concept.

3. Patronizing only those businesses that practice equal employment.

4. Implementing the civil rights bill's public accommodations provisions all across Alabama if and when Congress passed the bill.

5. Petitioning congress to reduce Alabama's representation in the Congress until the state's black citizens were allowed to vote freely.

But, it was not until December that SCLC seriously considered implementing Bevel's plan. 61

By the fall of 1964, the SNCC-led Alabama Voting Rights Project had run its course. SNCC had successfully organized the community to a point, but had been unable to reach a critical mass that would force the city and state to address their concerns or generate enough media attention, which would enable them to pressure the federal government to act. After two years of organizing and demonstrations, only 156 black voters had been added to the rolls in Selma. ${ }^{62}$ Ouellet recalled:

The whole thing kind of died in '63. People saw Selma as one movement. It wasn't. SNCC had done all it could, there was a lot of suffering, a lot of people got beaten, and so on. And so SNCC was kind of staggering in ' 63 There were a lot of cameras but nothing

61 Garrow, Bearing the Cross, 339.

62 Lewis, Walking with the Wind, 302. 
really happened and it was only later in '64 that this just resuscitated-- asking Dr. King to come to Selma. ${ }^{63}$

On November 6, the DCIA met with the mayor to request that the city address seven areas of concern: Equality of opportunity, equal pay for equal work, equal protection of the law, equality of suffrage, abolition of public segregation and that city officials and workers respect the dignity of all citizens. ${ }^{64}$ Their petition was ignored. It was now a war of attrition, and the SNCC staff was battered, bruised and running low on resources. ${ }^{65}$ Most of the activists were out on a peace bond, which meant that they forfeited bail money if they were arrested for so much as a traffic violation.

On November 11, Amelia Boynton attended an SCLC staff retreat in Birmingham. Speaking on behalf of the DCVL, she discussed the possibility of SCLC moving into Selma. The recent election of Smitherman, and his appointment of Wilson Baker as Public Safety Director, signaled a radical change in the city's politics. And while Smitherman was by no means a liberal on the race question, his election signaled a chink in the armor of Selma's white elite. ${ }^{66}$ Now, Boynton felt, was the time to press the city for real change, and SNCC's campaign was floundering. Recognizing that without outside help the movement would collapse, she extended an invitation to King, asking SCLC to come to Selma to help reinvigorate the movement. ${ }^{67}$

\footnotetext{
63 Ouellet interview.

64 Dallas County Improvement Association Petition. October 6, 1964. RSP Microfiche Reel 3.

65 Carson, In Struggle, 157-158.

66 Thornton, "Municipal Politics and the Course of the Movement," 51, 59.

67 lbid, 59.
} 
Among the SCLC staff there was general agreement that more effort needed to be directed towards registration efforts and securing federal voting rights legislation. C.T. Vivian noted that they "must have a rallying point around which we can stir the whole nation." 68 Bevel sensed that this was the opportunity he had been waiting for to launch his project. It was agreed that Selma might be the place to start and SCLC began preparations for a campaign in Selma. Vivian was sent to Selma to establish contacts with the city's black leadership. He soon discovered that Selma had all of the elements that SCLC needed for a successful campaign; a unified black community, glaring violations of African American's civil rights, and a racist southern lawmen with a quick temper. The start date for SCLC's entrée into Selma was a mass meeting that would break Hare's injunction set for January 2, 1965.69

68 Garrow, Bearing the Cross, 359.

69 Ibid. 


\section{Chapter 8 : "And so I will go in to the king."}

And so I will go in to the king, which is not according to the law. And if I perish, I perish.

Both the black and white communities began to prepare themselves for King's arrival. Mayor Smitherman and his new Director of Public Safety, Wilson Baker, tried simultaneously to ward off King and control Clark. Baker and Clark had a long and tumultuous relationship. Baker had served on the Selma police force as a captain for several years. In 1958 he ran against Clark for sheriff. The race was closely contested, with Clark running as an "insurgent populist" and Baker as a "law and order" candidate. Many observers believe that Baker lost the election by appearing at a Klan rally late in the race. ${ }^{1}$ His appearance at the rally cost him the county's black vote; just enough votes to give Clark the election.

After the election, Baker left the city and taught Law Enforcement at the University of Alabama. In his classes he discussed the tactics police forces had successfully used in combating demonstrations, specifically those employed by Albany Police Chief Laurie Pritchett. Pritchett had studied King and SCLC's tactics and decided to respond to nonviolent direct action with "nonviolent law enforcement."2 Without making visible the violence inherent in the segregation

\footnotetext{
${ }^{1}$ Charles Fager, Selma, 1965: The March that Changed the South (Boston: Beacon Press, 1985), 17.

2 Ibid, 19.
} 
system, SCLC's campaign in Albany had failed to generate any media attention. Pritchett arrested demonstrators and took them without incident to waiting jail cells and holding facilities. There were no incidents of police brutality. Without media interest to focus national attention on the campaign, King was unable to apply public pressure on the federal government to issue legislation against discrimination.

Like Pritchett, Baker and Smitherman hoped to beat King at his own game by meeting nonviolent demonstrations with nonviolent law enforcement. The only question was whether Clark would agree to go along. Smitherman and the new city council had created the position of Director of Public Safety earlier that fall in the hopes of isolating and controlling the sheriff. Smitherman and Baker argued that the jurisdiction of the new position superceded that of the sheriff's. The plan was to limit Clark to the courthouse. Baker hoped to keep the demonstrators clear of Clark, thereby preventing violence. From the outset, however, Clark resisted. Limiting Clark's authority meant limiting the authority of Clark's boss, Judge Hare, and Hare refused to let that happen. Hare challenged Smitherman and Baker's contention by citing an old state statute that declared the county sheriff to be the highest law enforcement officer in the city. ${ }^{3}$ The day before King's arrival, Baker told city attorney McLean Pitts that his jurisdiction covered everything in the city up to the courthouse steps.

3 lbid, 5. 
Baker and Smitherman also hoped they might be able to prevent King's arrival altogether. Smitherman and Baker were well aware that even moderate whites in Selma despised King, and that the presence of the SCLC in Selma would radically increase the potential for violence. Smitherman had been elected as a reformer who promised to bring new industry to the city. Violence meant bad publicity, and that could derail any deals Smitherman was working on. In December Baker traveled to Washington. He met with Department of Justice attorney Burke Marshall and retiring Attorney General Robert Kennedy. Baker asked Marshall to convince King to hold off on his plans until the new city government had a chance to prove itself. He promised to have the registrars open their books by June. Kennedy told him that SCLC had already invested too much in the Selma campaign, and alluding to Pritchett's success in Albany, Kennedy reminded Baker that he might "beat King at his own game."4

Not all blacks in Selma were pleased with King's impending arrival. SNCC workers were bitterly disappointed. Alabama Voting Rights Project Director John Love had not even been told by the DCVL leadership that they were considering inviting King into Selma. ${ }^{5}$ SNCC and SCLC had never worked well together. The organizations differed in tactics, philosophy, style, staffing and membership. SNCC was a younger, more radical organization made up of college students, while SCLC was made up of older, more conservative ministers. Each group had

4 lbid, 7.

5 Ralph Smeltzer, "Smeltzer Interview with Frederick Reese", July 17, 1964. RSP (Microfiche, Reel 3) 
a radically different understanding of movement leadership. In a 1965 SNCC

Field Report, Silas Norman and John Love detailed the organizations'

differences:

SCLC pushes hard for the idea that local people need leaders like Martin Luther King and Rev. Abernathy and others, while SNCC says that local people build their own leaders, out of their own communities-- that they build their self-confidence by doing this. Whether or not we will be able to work out these differences remains to be seen. 6

SNCC staffers felt SCLC was moving in on their turf. Julian Bond, SNCC Public Relations Director, summed up the feelings of the staff, "When King went to Selma, we had five people there for a year beforehand, really softening the community up So we just resented SCLC's ability to capitalize on things we thought we were doing." 7 SNCC had put a great deal of resources into the Alabama Voting Rights Project and felt that SCLC was going to take credit for a movement SNCC had initiated, nurtured and sustained for two years.

John Lewis had a unique relationship with SCLC. In addition to being SNCC Chairman, he was also an SCLC board member. He quieted some of the grumbling among SNCC workers by pointing out that the people of Selma had invited King to come. ${ }^{8}$ Eventually SNCC was forced to acknowledge their movement had bottomed out, and agreed to work with King and the SCLC. King arrived on January 2, and spoke at Brown's Chapel African Methodist Episcopal

6 Silas Norman and John Love "Selma Alabama" Alabama Field Report (No date; c. Early 1965), 3. SNCC Papers Microfiche.

7 Harold Raines, My Soul is Rested: The Story of the Civil Rights Movement in the Deep South. New York, Penguin. 1988), 214. 
Church to a packed audience. The mass meeting was the first in Selma in six months and was clearly in violation of Hare's injunction. A crowd of about 700 attended the meeting. King told the assembly "we will seek to arouse the federal government by marching by the thousands to the places of registration." The city had been chosen because it had "become a symbol of the bitter-end resistance to the civil rights movement in the deep South." If the Selma campaign did not succeed, King threatened to organize another march on Washington. ${ }^{9}$

Located next to the largest black housing project in the city, the George Washington Carver Homes, Brown's Chapel would become SCLC's headquarters. SCLC brought in a large staff to run the campaign including James Orange, the Reverend C.T. Vivian, Hosea Williams and James Bevel. Organizers canvassed the city in order to alert the community to ward meetings that were planned for Thursday, January 7. Baker was out of town the week of January 3, vacationing in North Carolina, and Clark's men had free run of the city. However, with no demonstrations, there were no flashpoints for violence. That Sunday, a Selma Times Journal editorial highlighted the co-operation law enforcement was exhibiting. ${ }^{10}$ At the ward meetings on Thursday, organizers allowed residents to give voice to their needs and desires for change.

\footnotetext{
8 John Lewis, Walking with the Wind: A Memoir of the Movement, (New York, Simon \& Shuster, 1998), 320.

9 King quoted in Lewis, Walking with the Wind, 307

10 Selma Times Journal, Sunday. January 3, 1965
} 
The first SCLC march to the courthouse took place on January 18 , 1965. Baker escorted the marchers from Brown's Chapel to the courthouse where, surprisingly, Clark managed to control himself. Simultaneously, other groups tested restaurants and hotels throughout the city. None of the groups integrating segregated establishments or attempting to register were molested by the police. King checked into the Hotel Albert, the city's premier hotel, and became its first black guest. The only violence occurred when James Robinson, a National State's Rights Party assaulted King as he was checking in. Baker forcibly removed Robinson from the hotel, and arrested him. ${ }^{11}$

King's presence elicited a renewed vigor and commitment on the part of the African American community, and that was made evident by an announcement evening at a mass meeting Monday evening. That night DCVL president and Selma City School Association (SCSA) president, Reverend Frederick Reese, announced that "before long" the black schoolteachers would march to the courthouse. ${ }^{12}$ Many movement leaders discounted Reese's announcement. The traditionally conservative teachers risked their livelihoods by marching.

Following the meeting, movement staff discussed the day's events. They were distraught over Sheriff Clark's uncharacteristic tame behavior, but decided to continue pressing the issue. Without tangible victories, the high spirit and high hopes of the community would begin to dissipate. Should Clark continue to

11 Garrow, Protest at Selma, 42. 
restrain himself the movement might quickly run out of steam. As a precautionary measure, SCLC considered expanding the scope of the demonstrations into the nearby towns of Camden in Wilcox County, and Marion in Perry County. The strategy was to locate the point of greatest resistance, focus their resources at that point and use the resulting violence against peaceful protestors to stir the nation to action. Organizers had planned on Clark providing the movement with its greatest point of resistance, and they still hoped he would not disappoint them.

Despite his unusually mild demeanor, Clark was furious with the way Baker was treating him and for appeasing King. The next morning he returned to form and ignored all of Baker's pleas for restraint in dealing with the demonstrators. SCLC sent a large number of marchers to the courthouse. Clark instructed the applicants to line up in an alley that ran alongside the courthouse. While both whites and blacks often used the side door of the courthouse, the marchers saw Clark's order as nothing more than an insult, and refused to move into the alley. They demanded that they be allowed to enter through the front door. Amelia Boynton was standing in-line to serve as a voucher for potential applicants. When she did not move fast enough for Clark, he placed her under arrest. He grabbed her by the collar and dragged her to his car within full view of a group of reporters. ${ }^{13}$

12 Fager Selma, 1965, 36.

13 Ibid. 
Sixty-seven demonstrators were arrested for failing to disperse and unlawful assembly. Those arrested were subject to a $\$ 500$ fine and six months hard labor on a chain gang. Local attorneys, as well as NAACP lawyers, were called in to arrange bail for the marchers. That evening Ralph Abernathy proposed to the DCVL that Jim Clark be awarded an honorary membership "for his sterling service in bringing the plight of black people in Selma to the attention of the Nation."14 Wilson Baker recalled that when Clark heard about his "award" on a surveillance tape made of the meeting, he swore he would never do it again. ${ }^{15}$

Having stirred Clark's wrath, SCLC sent three fifty-person waves of demonstrators to the courthouse on Wednesday, January 20. John Lewis led the first group. The marchers again refused to line up in the ally. Clark recognized Lewis in line and berated the SNCC chairman, "John Lewis you are an outside agitator and that is the lowest form of humanity there is." Lewis replied, "Sheriff, I may be an agitator, but I am not an outside agitator. I grew up only 90 miles from here, and we're going to stay here until these people can vote." Clark gave the marchers one minute to disperse. After the time elapsed and no one had moved, he bellowed, "Did you hear what I said?" Lewis calmly answered, "Did you hear what I said?" 16 All were arrested.

\footnotetext{
14 Ibid.

15 Steven Kasher, The Civil Rights Movement: A Photographic History, 1954-68 (New York: Abbeville Press, 1996) 165.

16 David Halberstam, The Children, (New York: Fawcett, 1998), 497.
} 
Clark then arrested the second group of demonstrators as they marched up the steps of the courthouse. When the third group appeared, Clark was incensed. Addressing Baker by his former rank, Clark demanded that "Captain Baker" assist his men in clearing the sidewalks. Baker calmly asked the demonstrators to form a single-file line. The marchers lined up and attempted to enter the courthouse through the main entrance. Clark once again ordered his men to force the marchers off the sidewalk and into the street. He then asked Baker to clear the street. Baker refused. Clark ordered everyone to disperse or line up in the alley. When they refused, he arrested them. Smitherman, the City Council and County authorities were not pleased with Clark's behavior, and tried to downplay the friction between the sheriff and Baker. On Thursday the City Council and the County Board of Revenue issued a joint statement. They declared, "However strong the provocation, calmness and self-restraint by each of us is the greatest protection for all concerned in this time of crisis." ${ }^{17}$ No demonstrations were planned for Thursday.

On Friday, January 22, the teachers' fulfilled their promise to march. SCSA members met at the Elementary School parking lot after school. Reese scheduled the march for Friday afternoon so that none of the teachers would have to miss work that day, and, if arrested, the teachers could be bailed out by the time school began on Monday. ${ }^{18}$ Almost every black teacher in Selma was present for the march. The group of about 100 people, led by Reese, walked two

17 Selma Times Journal. Thursday January 21, 1965. 
abreast to the courthouse. In addition to Clark, School Superintendent J. A.

Pickard and School Board President Edgar Stewart were at the courthouse. The two school officials asked the teachers to leave and called the march an "unprofessional display." Reese politely refused their request. He indicated that he and the teachers wished to inquire if the registration office was open, and if it was not, to file past it as a "sign of their concern over the way registration proceedings were handled." 19

Clark refused to let the teachers enter the building and announced that the teachers had one minute to disperse. Clark became enraged and shouted that Reese was making "a mockery, a Disneyland, of the courthouse." Fearing that Clark would once again lose his cool, city attorney Blanchard McLeod quickly pulled Clark into the courthouse. McLeod pointed out to Clark that if the teachers were arrested, all of the black schools in Selma would be closed on Monday which would allow an even greater number of students to participate in demonstrations. ${ }^{20}$ Clark appeared again and ordered the teachers removed from the steps. Reese and the teachers sat at the foot of the steps for a few more minutes and then quietly marched back to Brown's Chapel.

As teachers entered Brown's Chapel, the crowd erupted in a standing ovation. SCLC staff member Andrew Young cited the teacher's march as "the

\footnotetext{
18 Longenecker, Selma's Peacemaker, .

19 Fager, Selma, 1965, 39.

20 Ibid.
} 
most significant event in the racial movement since Birmingham."21 Charles Mauldin, a student at Hudson High and SNCC volunteer, remembered the importance of the teachers march for the black community. He noted:

Before that the teachers had always been reluctant, you know, because of their sense of responsibility and their sense of job security, to really come out and put themselves on the line. And so, after that it gave tremendous momentum to the local movement in Selma. Because it wasn't just students, or it wasn't just the rag-tag folks of Selma who had nothing else to do. That was the middle-class, given Selma's concept of what middle-class was at that time. ${ }^{22}$

Also, the march meant that registrars could no longer claim that blacks were not registered to vote due to a lack of education or intelligence. Young later wrote, "The teachers' march proved that the talk of blacks being 'unqualified' to vote was a smoke screen."23 As the teachers filed into Brown's chapel, the students began singing "Ain't gonna let nobody turn me around."24

Over the weekend, Judge Frank Thomas issued a restraining order against Sheriff Clark. Thomas was by no means a supporter of civil rights. The 1964 Civil Rights Act had singled out Thomas in a section known as the "Thomas Amendment," which provided for appeals in civil rights cases to be heard by a three-judge panel. The idea was to bracket known segregationist judges with two other, hopefully, less antagonistic judges. ${ }^{25}$ NAACP attorneys had appealed

21 Garrow, Protest at Selma, 44.

22 Charles Vaughn, "Dixieland Demonstrations: The Public Displays of Power in Selmians Struggle for Civil Rights," (Ph.D. Dissertation: Ball State University, 1999), 27.

23 Juan Williams, Eyes on the Prize: America's Civil Rights Years, 1954-1965, (New York: Viking Penguin Inc., 1987), 58.

24 Fager, Selma, 1965, 40.

25 Ibid, 42. 
Hare's July order banning all protest activity to Judge Thomas, and he had refused to rule on the case for almost six months. The Department of Justice had filed a motion the previous summer, and the case had been tried in December. The order prevented Clark from interfering with the voting rights process "under the guise of law enforcement." Thomas wrote, "the court believes that neither the plaintiffs nor the defendants have made or are making a sincere effort to obtain the registration of qualified voters in Dallas County in an orderly and effective manner provoked by an unnecessary assemblage of people at improper places."26 SCLC attorneys asked Thomas to clarify his ruling.

James Bevel preached on Sunday at the mass meeting at Brown's. He was upset with Thomas's ruling and saw it as a setback for the movement. The order, he exclaimed:

Might make it more difficult for us to do some of the things that we have done before, and we might be cited for contempt of court. But I don't mind being cited for contempt of court because Negroes were born under an injunction in Alabama. If Judge Thomas plans to connive around with the letters of the law in order to deny us our rights he has a bad dream coming We mean to vote and have our representation in government and we will settle for nothing less. And I am saying here and now that we must be prepared to fight and die for everything that is ours. And there is going to be rabble rousing all over Alabama until we get the right to vote. ${ }^{27}$

That day an editorial in the Selma Times Journal railed against the "professional outside agitators." More demonstrations were planned for Monday.

As the demonstrators approached the courthouse, Baker made sure that organizers not registering remained away from the applicants in line. Baker had

26 Garrow, Protest at Selma, 44-45. 
Willie McRae, a SNCC worker arrested. While McRae was being dragged from the scene by city policemen, Annie Lee Cooper stepped out of line to see what was happening. Cooper worked at the Dunn Rest Home until she had been fired and black listed for trying to register. As Clark pushed her, she turned and punched Clark in the eye. The blow stunned Clark, and as the sheriff fell to his knees, Copper landed another blow. Two sheriff's deputies grabbed her, but she was able to fend them off long enough to strike Clark a third time. Clark and some deputies finally wrestled Cooper to the ground but not before numerous photographs were taken of Clark beating his middle-aged assailant with his billy club. ${ }^{28}$ Baker meanwhile ordered all applicants who did not have one of the appointment cards to vacate the area.

That evening, as he addressed a mass meeting, Ralph Abernathy noticed a small microphone with an antenna on the podium. Abernathy declared that he was "not afraid of any white man, or any white man's doohickey either." He then began to preach to the device. He explained to his audience and those listening on the other end of the device that demonstrators would no longer abide by the city's parade ordinance. He proclaimed:

The next time we go, we are going to walk together. We are not going to go two together. Twenty feet apart. We're not going to have a parade, doohickey. We're just going to walk downtown. When we want to have a parade, doohickey, we'll get the R.B. Hudson High School Band and take over the town. ${ }^{29}$

${ }^{27}$ Fager, Selma, 1965, 43.

28 Ibid, 44.

29 Ibid, 46. 
Smitherman, Baker and Clark were fearful that the demonstrations were about to escalate. They were worried the marches would no longer be confined to the courthouse, and might begin taking place all over the city. Clark insisted that more law enforcement personnel be brought in. Al Lingo, head of the Alabama State Troopers, was asked to assist the city authorities and arrived the next day with three-dozen state troopers. ${ }^{30}$

Sisters Mary Paul wrote a letter to the Motherhouse in Rochester that night in order to "clear up many misconceptions, and allay the fears of so many well-intentioned people."31 In her letter, she clearly articulated the Sisters and the Fathers support of the movement. She wrote:

In one message something was said about the Sisters and Fathers being neutral. If that person meant neutral as I interpret it, then we are most definitely NOT neutral. For all practical purposes we are 'Negroes' living in a Negro community. Actually we do not think in terms of color. Nor do the children or the people think of us that way. To them we are Sisters and Fathers who are their brothers and sisters in Christ, living and working with and for them. It is just as simple as that. ${ }^{32}$

She told her Congregation that a large number of her students were participating in the demonstrations. She described how the children reported to Brown's Chapel, marched downtown, and were arrested. First time offenders, she explained, were released into the custody of their parents. Repeat offenders were sentenced to five days and fined $\$ 50$. Most refused to pay the fine. Sisters

\footnotetext{
30 Ibid, 46-47.

31 Mary Paul Geck, Newsletter to Sisters of St. Joseph Motherhouse, February 7, 1965. Sisters of St. Joseph Archives (SSJA), Selma Collection, Box: G13-1-2 File: "Letters from Sisters to others 14."

32 Ibid.
} 
Geck reported that on Friday evening the police had requested that the parents of jailed children come to the armory and collect their children. The police released many of children, as they had no more room and could not keep track of all of them. Sisters Geck wrote that for many students "it has become a status symbol to get arrested." Eight children from the grammar school were jailed and kept overnight.

Geck stressed to her congregation that both the sisters and fathers wholeheartedly approved of the children's participation in the movement. She then went on to describe a PTA meeting that was held the previous Wednesday. Noting that holding the meeting did seem somewhat ridiculous under the present circumstances, the Sisters felt that it was an important way to connect with the parents of their students during stressful times. To those parents who allowed their children to participate, the Sisters offered their support. To those parents who refused to allow their children to participate, the Sisters offered encouragement. ${ }^{33}$ She wrote:

These children are vitally concerned; after all their future is at stake in this project. They need to feel that they are a part of it. Besides, you have no idea of the effect it has on all of the children, even the little ones The older ones have been in a great state of agitation. My reaction to them is this; if I were one of them, I would want to be in on it, and if I had a teenage child, I would agree with his wanting to go. ${ }^{34}$

33 "Parish Full of Jailbirds," National Catholic Reporter, February 17, 1965.

34 Ibid. 
Geck recounted that most of the parents came to meet with the teachers, and then attended a mass meeting held later that evening. She closed her letter, noting:

To say or even to hope that all will be done quickly or quietly would be foolish and blind thinking. It will not be. There will be much sacrifice and much hardship before anything is really accomplished. But a beginning is being made, and this is important. We are living in the midst of a revolution, when we realize a revolution means violent change, not a war. Our children are children of a revolution and they feel it without necessarily being aware of the full implications of what it means. These are hard days for them-more than ever they need our understanding and love. We all need to become conscious of our relationships as sisters and brothers in the mystical body. "As long as you did it not to one of these the least of my brethren, you did it not to ME." Unfortunately the Church in the South is silent, for the most part All of this leaves the impression that is not new, that the Catholic Church is the 'white man's church.' It is a tragedy. We pray that it will come to an end soon. ${ }^{35}$

And the children were not the only ones arrested. Of the twelve members of the Holy Name Society, five had been jailed since the demonstrations began. The oldest parishioner, Peter Mace, was 80. Of the twenty-five women in the Ladies Sodality and at least a third of them have been in jail—most of them more than once. ${ }^{36}$

Fears of massive civil disobedience proved unfounded and marches to the courthouse continued over the next two days. Baker continued to insist that marchers walk two abreast in order to keep traffic clear, and Clark continued to send away all applicants over the 100-person limit. On Thursday, January 28th, King met with his senior staff to assess the situation and plan the week. It was

35 Ibid.

36 "Parish Full of Jailbirds," National Catholic Reporter, February 17, 1965. 
agreed that King would plan to be arrested on Monday, February 1st, the next scheduled registration day. It was hoped that his incarceration would draw even more media attention to the movement and provide King an opportunity to issue a "Letter from a Selma Jail." Like his Birmingham letter, the SCLC staff wanted to dramatize the issue and articulate the movement's goals. "This is Selma, Alabama," King wrote in the letter, "where there are more Negroes in Jail with me than there are on the Voting rolls." 37

As plans were being made for the march that would lead to King's arrest, the Birmingham News published a copy of a SCLC's Selma strategy memo it had obtained. ${ }^{38}$ While the Doohickey had not been able to gather any truly helpful intelligence, the "Project Alabama" memo detailed King's plan to present himself for arrest and to issue his "Letter from a Selma Jail." Within a day every law enforcement officer in the state had a copy of the memo. ${ }^{39}$ The question on everyone's mind was who would arrest King. Interestingly, SCLC staff, Smitherman and the City Council all wanted Baker to take King into custody. Smitherman did not want Clark assaulting King. Ironically, Clark seemed to agree. Clark felt that it was time for Baker to get his hands dirty. For his part,

37 Garrow, Bearing the Cross, 386. Martin Luther King, "Letter from a Selma Jail," February 5, 1965 New York Times.

38 "King's arrest said second phase of 'master plan' for Negroes," Birmingham News. February 2, 1965.

${ }^{39}$ Raines, My Soul, 197. 
Baker did not want to be the arresting officer. 40 On Sunday evening, King told the mass meeting:

Whatever it takes to get the right to vote in this state we're going to follow that course ... If it takes filling up the jails. If it takes marching in the streets of this city day after day ... If it takes marching to the state capital en masse and standing before the governor to demand our rights. ${ }^{41}$

That evening, Judge Thomas finally issued his clarifications for his earlier ruling prohibiting Clark from interfering with voter registration. He ruled that the registration line could not be limited to the first 100 applicants nor could civil rights workers be prevented from assisting and advising those in line. ${ }^{42}$

On Monday, Wilson Baker outside of Brown's Chapel met King and a group of 250 demonstrators. The group walked together in violation of Baker's directive against parading without a permit. Baker demanded that the marchers break up into smaller groups. King told Baker that they had a right to march and refused to comply. He then led the marchers past Baker, who stepped aside. Baker stopped the group a few blocks later. King asked if he might lead his group in prayer. Baker allowed him to do so, and when he finished placed all of the marchers under arrest.

King and Abernathy refused to post bond, much to the dismay of city officials, and were placed in a cell with the other marchers. In addition to King's group, another 200 high school students were arrested that day by Clark at the courthouse. Those marchers were taken to the armory to be processed. Judge

40 Fager, Selma, 1965, 48.

41 Ibid, 49. 
Reynolds presided on the floor of the field house and released many of the young demonstrators into the custody of their parents. Some refused to cooperate and were sent to Camp Selma on buses. More demonstrations and mass arrests continued for the next several days and severely tested the city and county's resources.

On Tuesday, Clark arrested close to 400 school children and made liberal use of his cattle prod. That evening Governor Wallace made an appearance in Selma. 43 Only local reporters were allowed to attend the event. Wallace spoke about industrial development in the state under his administration and did not mention the demonstrations at all. On Wednesday, the Hammermill Paper Company made a long awaited announcement that it planned to build a thirty million dollar paper processing plant east of the city. ${ }^{44}$ The facility would create 250 jobs and bring in a substantial amount of taxes.

That evening Malik el-Hajj Shabbazz, formerly Malcolm X, spoke at Brown's Chapel. Shabbazz had been invited by some SNCC staff members who attended a speech he gave at Tuskegee Institute the previous night. ${ }^{45}$ Shabbazz's remarks were rather tame. As he left the podium he asked Mrs. King to pass along his good wishes to her husband. He mused that his presence in

\footnotetext{
$42 \mathrm{lbid}, 48$.

$43 \mathrm{lbid}, 54$.

$44 \mathrm{Ibid}, 55$.

45 Ibid, 57. Following his break with the Nation of Islam, he changed his name to Malik El Hajj Shabazz.
} 
Selma might make King's job easier once the white community realized that there were those in the black community who did not advocate nonviolence. ${ }^{46}$ Judge Thomas issued another injunction against the Dallas County Board of Registrars. The Board was ordered to process 100 applicants a day, to stop using the state literacy test, and to act on all applications submitted by June 1 , 1965. Thomas wrote the order after consulting with the Board and Clark. ${ }^{47}$ The Board hoped that by discontinuing the use of the literacy test, it would render moot the Justice Department lawsuit filed a few days earlier that sought to end its application statewide. However, the order did not require the Board to meet more often. With only eight more registration days scheduled, Thomas' deadline of June 1 meant that the Board would be required to process only 800 more applicants. Since nothing was said about how many applicants had to be accepted, it would take years to register all of the county's black voters under this system.

All in all the order seemed like a major concession on the part of the county and a victory for the movement. If SCLC continued to press for change, their opponents could brand them as sore winners. But organizers realized that this order in did not affect the hundreds of other communities throughout the state. What they needed was national legislation. ${ }^{48}$ On Friday, organizers again

\footnotetext{
46 Ibid, 57.

47 lbid, 58.

$48 \mathrm{lbid}, 59$. See also Garrow, Protest at Selma, 51.
} 
sent marchers to the courthouse, all of whom were arrested. Over 3,000 protesters had been arrested in the first week of February alone. 49

Father Eymard Galligan, Superior General of the Society of St. Edmund and former Director of Southern Mission traveled from Vermont to visit the mission that month. On Friday, February 5, he called Wilson Baker, whom he had known from his days as Director of Southern Missions, and asked if he and Crowley might visit King in jail. Baker agreed, and the two priests went to the jail that morning. King did not know much about the work of the Edmundites, and Crowley invited him to visit the Good Samaritan hospital when he was released. King thanked the priests and told them he looked forward to speaking with them later.

On the afternoon of Friday, February 5, King posted bond and met with a Congressional delegation that had come to investigate the situation in Selma. The delegation included Representative Charles Diggs, John Dow, Jonathon Bingham, James Scheuer and Ogden Reid. The group spoke with a number of movement leaders and city officials. They took depositions and returned to Washington that evening. King's "Letter from a Selma Jail" was published that morning in the New York Times. Friday evening he traveled to Atlanta and then to Washington, where he was scheduled to meet with the President on Monday. ${ }^{50}$ No demonstrations were held over the weekend. Over the weekend, Andy Young and Frederick Reese negotiated with city officials. They agreed

49 bid, 59. 
upon an appearance book. The idea was to have potential applicants sign the book, thereby guaranteeing their spot in line. The applicant's names would be called from the book in the order in which they appeared. Applicants did not have to wait in line all day.

On Monday, Jim Bevel led a large demonstration to the courthouse. Bevel was furious that Young and Reese had agreed to the appearance book. Chairman of the Dallas County Board of Registrars, Victor Atkins, insisted, "the board feels that the opening of the appearance book provides a reasonable basis on which Negro leaders can and should remove demonstrators from the street." 51 Bevel disagreed and saw the book as a ploy to delay registration, and remove the one means the movement had to pressure the city. Bevel and his group refused to sign the book. Clark was infuriated and bellowed, "You are making a mockery out of Justice." Bevel began to explain the Constitution to Clark, who once again lost his temper. Clark and five deputies began to beat Bevel. Bevel lost consciousness repeatedly during the beating. He awoke in his cell soaking wet and freezing. Clark had ordered his deputies to hose down him with cold water and to prop open his window. That evening a lawyer for Bevel's wife, fellow activist Dianne Nash, came to serve him with divorce papers. The lawyer insisted on seeing Bevel and found him unconscious in his cell. He was delirious

50 Garrow, Protest at Selma, 55. Fager, Selma, 1965, 60.

51 Victor Atkins, Selma Time Journal February 8, 1965. 
with a high fever. The lawyer alerted SCLC officials who negotiated to have Bevel treated. 52

That evening Dr. Ed Maddox approached John Wright, the newly appointed Director of Public Relations for Good Samaritan. Wright, a Catholic, had worked for a number of years as a reporter for the Birmingham News and later for the Alabama diocesan paper, the Catholic Week. He had been recruited by Father Galligan to work at the hospital a few months earlier. The situation in Selma and his affiliation with the mission were beginning to place a serious strain on Wright and his family. Of his first few months in the city, he recalled.

My wife and I, we were welcomed by the young white professionals But after January that changed. My wife today finds it very painful to talk about Selma; it caused her major emotional problems. After January, I had to decide what side I was going to take personally because it was a moment of truth, and I never once attempted to compromise that. I thought what the Sisters and priests were doing was heroic, unappreciated by the local community. Now, I did not, and I want to make this clear, go down to the line and march, but my heart was always there. ${ }^{3}$

Maddox told Wright about Bevel's condition. Bevel had been taken to Burwell Infirmary where he lay shackled to his bed. ${ }^{54}$ No white doctor would treat him, and Maddox wanted to know if there was anyway Wright might be able to arrange for him to have Bevel treated. Although new in town, Wright told Maddox that he would see what he could do. Wright had began to "get his face known" around town by having lunch at the Selma Dell, a local café on Broad Street. Wright phoned the owner of the café, Otis "Red" Adams, and asked if he

52 Halberstam, Children, 501.

53 John Wright Interview by author (March 18, 1994). 
would use his contacts around town to arrange for Maddox to treat Bevel. Within an hour, Adams called Wright and told him that if he showed the guards a letter of introduction from Good Samaritan, Maddox would be allowed to treat Bevel. 55 Wright spoke with Father Crowley, and the two typed the letter of introduction. Then Wright, Crowley and Maddox went to the infirmary. The group asked if the shackles could be removed, but the guards refused claiming that Bevel might try and escape. Maddox pointed out that Bevel could barely stand, let alone flee. Again the request was denied. Crowley recalls the limited room that whites felt they had to maneuver in when the issue of race was involved. They had an incredible fear of appearing "to be soft on these people." 56

That week Galligan and Crowley discussed plans to issue a statement on the demonstrations. Crowley felt that the Catholic Church's position should be clearly articulated, and he was convinced that Archbishop Toolen would not address the matter publicly. Crowley decided against holding a press conference because he feared segregationists would misquote him. A written statement, Crowley recalled, would allow me "to suppress my natural Irish anger and not touch sore buttons or, at least, touch them gently." ${ }^{57}$ Crowley wrote the piece with help from Wright. Crowley wanted to make clear that the restriction not to march placed on them by the archbishop did not indicate a lack of support for those who marched. For Wright, the chance to articulate the principles that

\footnotetext{
54 Ibid.

55 John Wright Interview.

56 Crowley Interview.
} 
guided him in choosing to side with the movement was a welcome opportunity. Wright suggested to Crowley that he end the piece with the Prayer of St. Francis. ${ }^{58}$

On Sunday February 7, Crowley took out a full-page ad in the Selma-Times Journal. Entitled "The Path to Peace in Selma," the piece was addressed to both white segregationists and black demonstrators. The document was written from the perspective of a Catholic and an American; it was the statement of a clergyman and a Selma resident. Crowley wrote:

We do not have ready, simple solutions to the problems that confront the community. We realize their complexities. However, we do know from personal experience the truth of the Negro claims of injustice, and the evil effects of discrimination on his mind, body and soul. That is why we support wholeheartedly those nonviolent efforts to obtain their full rights as Americans. ${ }^{59}$

He set fourth his belief that the problem was fundamentally a moral dilemma, and that the path to peace lay in the application of Christian love.

Crowley drew upon a number of traditions to support his point that all men and women should be treated with respect and dignity. He discussed the theological ramifications of Christ's sacrifice on the cross, and the Catholic understanding of man's unity through the mystical body of Christ. He noted that universal dignity had been affirmed by the founding fathers of this nation, and that it was a prominent theme in the works of the great poets of western civilization. Crowley praised the efforts of law enforcement officers, while

57 John Crowley Telephone Interview by author (July 11, 2001).

58 Crowley Interview. 
reminding them of their duty as Christians to love their neighbors. He also lauded the nonviolent philosophy and discipline of the demonstrators, and affirmed their right to protest.

Toolen was not pleased with the statement. Crowley heard that the Archbishop was furious with him and went to Mobile to discuss the matter. Toolen had refused to allow Crowley's piece or any mention of it to be published in the Catholic World, the diocesan paper. In fact, no mention of demonstrations was printed in the paper. When Crowley met with the Toolen, the Archbishop gruffly asked him if he "was an expert on race relations now?" Crowley said he was not and asked if the Archbishop liked the piece. Toolen answered that it was "alright." 60

On February 10, Crowley received a call from the hospital. King had taken up Crowley's offer to visit the hospital and had appeared unexpectedly. Crowley instructed the Sisters to give King an extended tour of the facility and said that he would be right over. He called Ed Moss, John Wright and a number of other mission personnel and rushed off to Good Samaritan. But before he left he grabbed a plaque with the prayer of St. Francis that hung on his office wall. When Crowley arrived he presented King with the "St. Francis Peace Prize"-an award that he concocted on his dash from his office. The white doctors at Good Samaritan were not pleased with King's visit, and one told Crowley that he could not believe the Fathers were getting involved in politics. Crowley replied, "Are

59 John Crowley, "Path to Peace in Selma" Selma Times-Journal February 7, 1965. 
you kidding me? What do you think we have been doing here for the last thirty years?"61

On Tuesday, the movement reached a low point. Sisters Michael Ann, S.S.J., chief administrator of Good Samaritan hospital, issued a statement to the staff over the loudspeaker system, saying:

We stand with you in your efforts toward securing those rights guaranteed by our Constitution. We encourage you to do all you feel able to do but always in a nonviolent manner. We follow in the footsteps of Christ who suffered all things to secure a new law. I wish to state that no one's job will be jeopardized by their participation in any demonstration that is guided by your designated leaders. We know that your activities will be a reflection of the same control and love that is characteristic of your work in the hospital. 62

But few people had attended Monday's mass meeting, and even fewer participated in demonstrations at the courthouse. It seemed as if the movement was running out of steam. The city was claiming that it had addressed all of the movement's concerns, and with no violence to report on, the press was close to moving on to a new story.

On Wednesday Clark confronted a group of Selma high school students. Members of the group were holding signs that read, "Jim Clark is a Cracker" and "Wallace Must Go."63 Clark removed the men who were posted closest to the students and parked school buses between the students and the press. At noon Clark ordered fried chicken for his men and had them eat in front of the students,

60 Crowley Interview.

61 Ibid.

62 Sisters Michael Ann "Official Statement" ( February 9, 1965) Selma Mission Archives. 
most of whom had been standing for over two hours on the picket line. The students responded by marching around to the other side of the courthouse.

Clark's restraint, however, was short lived. He soon snapped, and on the pretense of dispersing the students, ordered his men to chase the children down the street with their cattle prods. The children were chased almost six miles out of town to a county facility for training police dogs. Throughout the chase Clark screamed, "Now march! You wanted to march, didn't you!"64 Just as the children's arrest in 1963 had done, this forced march galvanized the community's support for the movement. The brutal treatment of children, some as young as ten, rallied the community and refocused national press coverage on the city. Wilson Baker later lamented that the city was "a day away from the Selma movement moving on."65

Clark was exhausted by the nonstop demonstrations, and checked himself into Vaughn Memorial Hospital on Friday February 12. Outside his window schoolchildren prayed for his recovery and carried signs that read "Get Well Soon" and "Freedom Now." Clark emerged from the hospital refreshed and with a renewed sense of purpose. Seemingly in answer to the children's placards, Clark's response to his opponent's chants and signs was summarized by a button on his lapel that simply read "NEVER."66 Marches to the courthouse continued, and SCLC stepped up its efforts to bait Sheriff Clark. On February 16,

\footnotetext{
63 Fager, Selma: $1965,66$.

64 Ibid, 67.

65 Raines, My Soul, 199.
} 
SCLC Director of Affiliates, the Rev. C.T. Vivian, led a march to the courthouse and verbally sparred with Clark. Vivian played to the cameras as he berated the sheriff. "If we are wrong, arrest us, but don't force us to leave!" Vivian declared, "We don't mind being beaten and going to jail for democracy! I know you want to beat me!"67 Clark could not resist Vivian's taunts, and punched the minister in front of the cameras.

At the same time, the movement leadership planned to escalate the demonstrations in scope and tactic. Night marches were planned. In addition to Selma, areas outside of the city were targeted for demonstrations. James Orange of SCLC began organize a voter registration movement thirty miles northwest of Selma in Perry County. Earlier that week, he was recruiting high school students in Marion, the county seat, and had been arrested for contributing to the delinquency of a minor. C. T. Vivian and SNCC worker Willie Bolden traveled to Marion on Thursday to speak at a mass meeting at the Zion Chapel Methodist Church. An evening march protesting Orange's arrest was scheduled for that evening. In addition to the movement staff, a large group of reporters traveled to the city to observe the march.

The march was to be a small one. Marchers were to proceed from the Chapel, across the town square to the jail where they would pray. The marchers had not all exited the church when Al Lingo of the Alabama State Troopers

\footnotetext{
66 Lewis, Walking with the Wind,
} 
confronted the marchers. Lingo ordered the group to disperse. Organizers began to lead those in the front of the march in prayer. Within moments of Lingo's order, the streetlights went out. Simultaneously, a contingent of Alabama State Troopers accompanied by Jim Clark's posse rushed the demonstrators. The troopers and posse men clubbed and prodded the demonstrators. No one could retreat into the church because men and women were exiting to see what was happening. SNCC worker Willie Bolden was quickly arrested. The Marion sheriff told him that if he had "kept his black ass in Atlanta" this would not have happened. Bolden answered that he was from Selma, and that he had a constitutional right to peacefully protest. The sheriff retorted, "You don't have any constitutional rights in my town."68

The reporters had been off to the side of the march, but as the assault began they rushed to get a better view. As they did, they too became targets of the mob and the troopers. Extinguishing the streetlights served a dual purpose, it created chaos among the demonstrators, and it made it difficult for the reporters to get photographs of the assault. To make sure that the reporters could not take photos, the attackers sprayed their camera lenses with black spray paint. ${ }^{69}$ Richard Valeriani, a reporter for NBC was in Marion that evening. As the assault

67 Fager, Selma: 1965, 70. This particular and many other of these exchanges between Clark and Vivian are captured on video contained in the sixth and final episode of the "Eyes on the Prize" Documentary series.

68 Raines, My Soul, 191-192.

69 Ibid. 
began, he was struck over the head with an axe handle. ${ }^{70}$ Peter Fisher, a UPI photographer, was also attacked.

In the ensuing melee, a trooper shot Jimmy Lee Jackson, an eighteenyear-old demonstrator, at point blank range. Local activist Albert Turner described Jackson as someone who attended the meetings, but was not overly involved. Turner recalled:

About this time everybody was active This was one of the prime reasons for the massacre. Because too many people were getting the message, and a lot of black folks who hadn't never rebelled against the system at all had decided that it was time to rebel against the system. And the white power structure knew that as many people we had sympathizing with us at this point, that something had to go one way of the other. And their theory was to try to deter us with force or to brutalize us. ${ }^{71}$

Jackson and his mother, Viola Jackson, tried to escape the assault by hiding in the foyer of a storefront. A trooper followed them in and began striking Mrs. Jackson. Jackson lunged at the Trooper, who threw him up against a cigarette machine. A second trooper appeared and fired his revolver point blank into Jackson's stomach. ${ }^{72}$ Jackson was taken to the Perry County hospital, but when the staff realized that he would require a blood transfusion, he was taken to Good Samaritan Hospital. Fifteen to twenty people were hospitalized and scores of

\footnotetext{
70 Richard Valeriani Interview by Chris Matthew on MSNBC (March 25, 1997). URL: http://www.msnbc.com/onair/modules/valeriani.asp. See also Fager, Selma, 1965, 73. 71 Ibid, 189. 72 Fager, Selma: 1965, 72-75.
} 
others were injured. ${ }^{73}$ When Clark was asked why he was in Marion that evening, he replied, "Things got a little too quiet for me in Selma tonight."74 When news reached Selma, a march was hastily organized, but Wilson Baker kept the marchers from leaving Brown's Chapel in order to prevent further violence. Governor George Wallace issued a ban on all night marches on the 20th. SCLC was unsure how to proceed. Originally they planned to defy Wallace's order, but pressure from the Justice Department on Monday night led King to call off the march. SNCC disagreed with the decision, which was based mainly on Justice Department reports of potential violence against King, and John Lewis led a small march that night in protest.

Jackson arrived at Good Samaritan late Thursday evening. He was in critical condition. Sisters Barbara Lum remembers speaking with Jackson on a daily basis. The doctors and nurses struggled to keep the young man alive, but due to the extent of his injuries they held out little hope for his recovery. She recalled he was always very pleasant despite the pain he was in. ${ }^{75}$ The irony of the movement in Selma was that while white on black violence had increased, violence within the black community had drastically decreased. Sisters Lum recalled:

One thing that I loved was that during the civil rights movement, before all of the mass meetings began, our emergency room on a Friday and Saturday nights was a bloodbath. If you were working nights, you were sure that you would be busy with people cutting each other. Black-on-black violence.

\footnotetext{
73 Kasher, Civil Rights Movement, 165-166.

74 Fager, Selma: 1965, 74.

75 Barbara Lum Interview by author (December 2001).
} 
During the whole civil rights movement, that stopped. People were busy and they had a new self-respect. ${ }^{76}$

However, the demonstrations made the possibility of violence and large numbers of casualties a real possibility. The hospital staff was never sure what might happen at demonstrations and tried to be prepared for the worst-case scenario.

On February 23, Col. Al Lingo, head of Alabama's State Troopers, served Jackson with a warrant for his arrest, as he lay in his hospital bed in a coma. He was charged with the attempted murder of a state officer. In addition to the blatant attempt by the state to blame Jackson for his own injuries, rumors began to circulate among the white community that Jackson's injuries were not life threatening. Many felt that the movement was not treating him in the hopes that he would die thereby giving the movement its first martyr. After years of service to the community, the Sisters were deeply upset by the insinuations of improper care. ${ }^{77}$ As the condition of Jackson deteriorated and the State of Alabama continued to deny responsibility for the incident, pressure on SCLC mounted for a response to the rampage in Marion. On the morning of Thursday, February 25, Jackson passed away.

SCLC staffer James Bevel preached at the first memorial service for Jackson in Marion that night. He chose Esther 4.8 as the text of his sermon:

Mordecai also gave him a copy of the written decree issued at Susa for their destruction that he might show it to Esther and charge her to go to the king to make supplication to him and to entreat him for her people. ${ }^{78}$

76 Ibid.

77 Ibid.

78 Esther 4:8, New Oxford Bible (RSV) (New York: Oxford University Press, 1971) 
Bevel had been playing for some time with the idea of a march to the State Capitol in Montgomery to present their grievances to Governor Wallace. The audience had been extremely receptive to the idea, as Bevel chanted, "I must go see the King!" He presented his plan to the movement strategists that night. SCLC staff members agreed that it had merit. Not only would the march demonstrate the inability of blacks to register and vote in Selma, but it would also draw attention to the conditions in Lowndes County, one of the counties marchers would pass through on their way to Montgomery. While the population was $81 \%$ black in Lowndes, there was not a single African American voter registered there. ${ }^{79}$

SNCC staff members, on the other hand, opposed the idea of a march. They thought it was not in the best interest of local leadership development. 80 Mary King, SNCC staff member at the organization's Atlanta Headquarters, recalled:

I thought that a march, although providing brief gratification and the exhilaration of a mass mobilization, was unrelated to our long-term goals and would produce few serious political results in the hamlets of Alabama. I decided that the march was regressive and along with others refused to participate. ${ }^{81}$

In spite of SNCC's objection, SCLC decided to proceed. On March 3, the day of Jackson's funeral, King informed the press that the plan to march to Montgomery

\footnotetext{
79 Powledge, Free at Last, 613.

80 Carson, In Struggle, 158-159.

${ }^{81}$ Mary King, Freedom Song: A Personal Account of the 1960s Civil Rights Movement (New York, Quill William Morrow: 1987), 476.
} 
was official. Sunday, March 7, was chosen as the date for the march to commence.

The week leading up to the march was extremely tense. Arrests and beatings occurred on Monday at the courthouse, and the American Nazi Party, as well as the National State Rights Party, had again sent groups into the city. Wallace and Lingo met on Thursday and Friday to discuss how the march was to be handled. Governor Wallace originally thought that the march should be allowed to proceed, as he doubted the ability of SCLC and SNCC to organize such a tremendous undertaking. Smitherman and Clark were informed of the Governor's decision.

Wilson Baker was out of town on vacation. When he returned he was incredulous. He did not think that it was possible for anyone to believe that $\mathrm{Al}$ Lingo and Jim Clark would allow a group of demonstrators to march through their county to the State Capitol. The march would take place outside of his jurisdiction, and Baker refused to take part in what he saw as an inevitable blood bath. He agreed to station two city police officers at the city limits.

On Saturday March 6, a bizarre spectacle occurred. Seventy whites from the Concerned White Citizens of Alabama (CWCA), led by the Rev. Joseph Ellwanger, marched to the courthouse to protest the lack of voting rights. Ellwanger, a Lutheran minister, had grown up in Selma and now lived in Birmingham. He was the son of the president of Selma's Concordia College. The marchers were predominantly ministers and academics. The group 
marched to the courthouse and began to read a statement when a mob of whites encircled them. While Selma's whites and blacks had become used to the presence of the white Yankee priests and Sisters, white Southerners were another matter all together. Some in the mob were American Nazi Party members, and they began to rough up the group. The CWCA marchers left quickly before anyone was hurt. Without the CWCA to focus their attention, the mob began to round up and beat any civil rights worker they could find.

That evening SNCC staff members met at Frazier's Café in Atlanta to discuss their stance regarding the proposed march. Julian Bond, Marion Barry, Silas Norman, Wilson Brown, Bob Mants, Ruby Doris Robinson, Courtland Cox, Ivanhoe Donaldson and James Forman attended. Most opposed any SNCC participation in the march. The group felt that the march focused attention on national figures like King and away from local leadership development. Animosity toward SCLC for reaping the benefits of what SNCC had worked so hard to sow was also evident. Eventually the group put together a statement that read:

We strongly believe that the objections to the march do not justify the dangers ... .consequently SNCC will only live up to those minimal commitments ... to provide radios and cars, doctors and nurses, and nothing beyond that. ${ }^{82}$

John Lewis again found himself in a dilemma. He felt that the most important issue was that the people of Selma wanted to march. Their will, he believed,

82 Lewis, Walking with the Wind, 
overrode any organizational differences SNCC and SCLC might have. Lewis told the meeting:

I'm a native Alabamian, I grew up in Alabama. I feel a deep kinship with the people there on a lot of levels. You know I have been to Selma many, many times. I've been arrested there. I've been jailed there. If these people want to march, I am going to march with them. You decide what you want to do, but I am going to march. 83

Lewis left Atlanta early Sunday morning and drove to Selma to join the march.

The logistical problems such a march posed were enormous. The journey

from Selma to Montgomery was fifty miles through rural Alabama along Highway

80. Above and beyond the problem of arranging for food and shelter in rural

Alabama for a large march, was the question of safety. Lowndes County was a

Klan stronghold and the terrain along route 80 provided more than enough

opportunities for ambush. But few expected the marchers to make it past the city limits. John Crear came by the hospital on Sunday morning to pick up a first aid kit he had asked Sisters Lum to prepare for the marchers. Lum recalled preparing the kit:

[I placed] something for windburn something if you sprain your ankle. [That there would be violence] never entered my mind. Why it never entered my mind I don't know. I had certainly seen enough of the violence that the police and the sheriffs were capable of, but nobody was acting as if they were walking into something really dangerous .. . I gave them what I thought would be. 84

That morning, marchers gathered at Brown Chapel.

83 Ibid.

84 Lum Interview. 
SCLC staffers Andrew Young, James Bevel and Hosea Williams and SNCC Chairman John Lewis met that morning to discus how to proceed. There was some confusion as to who was going to lead the march. King was not in Selma. He was in Atlanta preaching at Ebenezer Baptist Church. Young called King. Young asked, "Look, all these people here are ready to go now. The press is gathering and expecting us to go, and we think we have got to march even if you aren't here. There'll probably going to be arrests when we hit the bridge." 85 King told Young to send one SCLC staff member with John Lewis and for the remaining two SCLC staffers to remain behind to coordinate activities in case of trouble. He told them to flip a coin to decide who would lead the march. Young and Williams decided that they would flip to see who would go and who would remain behind. Williams won. He and Lewis led the march. Oddly enough, Clark was not in town either. He had agreed to tape an interview in Washington that Sunday. Baker arranged to have AI Lingo pick Clark up at the airport in Montgomery that afternoon in the hopes that the two might not be around when the march began. But the confusion caused by King's absence delayed the march, and gave Clark and Lingo enough time to get back to the city.

The 525 marchers led by Lewis and Williams arrived at the bridge late in the afternoon. The troopers were lined up on the east side of the Alabama River, at the far end of the Edmund Pettus Bridge. Some marchers wore their Sunday best and did not expect to get very far. Others were more hopeful wearing 
comfortable clothing and carrying bundles of blankets and toiletries. The troopers wore gas masks and carried billy clubs. The marchers approached the line of troops and were informed by Major John Cloud of the Alabama State Troopers that the march was illegal. Hosea Williams and John Lewis requested to have a word with him. Cloud refused. The exchange was repeated and Cloud then ordered the troopers to advance.

The advance began slowly, but soon the marchers were unable to keep pace with the pressing troopers. When the first marcher fell down, all hell broke loose. Marchers were struck with billy clubs, and as the troopers reformed their lines, the protesters were bombarded with tear gas and charged by Clark's mounted posse armed with nightsticks, bull whips and cattle prods. Some groups raced for a low lying area just off the highway, but tear gas bombs were thrown into this area until there was no retreat, no exit. Lewis described the effects of the gas:

"We were utterly helpless. The tear gas simply drove our folks to the height to desperation. We screamed, hollered, prayed, ran everywhere to escape the suffocating fumes. Women vomited. Men gasped for breath and fell out exhausted. Meanwhile, now circled by the troopers, these suffering people again were whipped, kicked by horses, shocked by cattle prods."

Lewis covered his head with his arms and dropped to his knees in what he called the 'prayer for protection.' He later recalled that he sensed others were hurt far worse than me, and so he began to assist women and children. ${ }^{86}$

85 Andrew Young, An Easy Burden: The Civil Rights Movement and the Transformation of America, (New York, Harper \& Collins: 1998), 355.

86 "Tragedy Stalks King in Alabama," Jet, March 26, 1965, 21. 
Marchers fled back across the bridge while others lay scattered on the ground. The mounted posse reformed its ranks and advanced again. Lewis recalled, "Some even jabbed their horses into the flanks and had them prance upwards and bring their feet down on shoulders, stomachs and feet."87 After the initial assault, Hosea Williams felt that the attack had ended.

We thought it was over and we could regroup and handle our wounded. But our ambulances were not allowed to cross the bridge and come to our rescue. Then to my utter shock, I noticed the troopers putting on gas masks. ${ }^{88}$

Cried a marcher: "God in heaven, how can people hate us so. This was a living hell."89

The troopers and posse men pursued the marchers the three miles to Brown's Chapel. Troopers were yelling "beat the niggers" "kill the black SOB."90 No one was safe from their wrath, and soon bystanders and marchers alike were being assaulted. The churches provided little refuge. One young man was taken out of First Baptist Church and hurled through a stained glass window. "They literally whipped folk all the way back to the church," remembered one marcher. "They even came up in the yard of the church, hittin' on folk. Ladies, men, babies, children -- they didn't give a damn who they were."91 The rampage lasted more than three hours.

87 Ibid.

$88 \mathrm{Ibid}, 22$.

89 Ibid.

$90 \mathrm{lbid}, 20$.

91 Kasher, Civil Rights Movement, 167. 
Towards the end of the skirmish, nonviolent discipline began to collapse as blacks began to retaliate. Rocks and bottles were the first weapons to be used, but as the situation deteriorated, men armed themselves with knives, shotguns, rifles and pistols. Andy Young was able to dissuade anyone from taking action by pointing out the fact that the blacks were out manned and out gunned by the troopers, and that any excuse to wipe out the demonstrators would be used by Clark and Lingo.

SNCC dispatched six radio cars to serve as ambulances but troopers and possemen continued to assault the wounded -- even those being carried. ${ }^{92}$. Ambulances packed with the wounded hurried over to the hospitals and first aid stations. One driver insisted he made more than ten trips-- even of those not participating. The Medical Committee for Human Rights had established a first aid center in the basement the First Baptist Church and treated marchers. ${ }^{93}$ Some of the wounded were taken to the Burwell Infirmary, but most were taken to Good Samaritan Hospital. Soon the staff was overwhelmed.

No one at Good Samaritan was aware of what had occurred at the bridge. Not all of the Sisters were on duty at the hospital. Sisters Mary Paul Geck was at the convent when she got a call from Sisters Michael Anne who asked her to send all of the nursing Sisters over to the hospital. Moments later Sisters Michael Anne called again and asked for all of the Sisters to get over to the hospital as soon as they could. When they arrived it was bedlam. Sisters St.

92 Ibid, 22. 
Joseph Creighton was at St. Elizabeth's Chapel praying when she heard the sirens of the ambulances and police cars. She had been in Selma for less than a year. "I heard the whistles and sirens and I knew instinctively," she said. "I left and hurried to the hospital." When she arrived she was stunned by the sheer number of people involved. "The flow of patients was constant, Sisters St. Joseph recalled. "We just kept moving from patient to patient. It just never seemed to stop."94

As patients began to arrive, the hospital was in the midst of the change between the day and evening shifts. "The day staff stayed where they were, the evening staff helped with the emergency," Sisters Lum recalled. "People were all standing in the hallway waiting to be told what to do."95 Sisters Geck began registering each patient. Descriptions of admitted patients in the hospital's logbook for that day begin in a neat and orderly fashion as Geck recorded each patient's name and a short description of their condition. As the flood of victims began to overwhelm the emergency room, the descriptions rapidly degenerated, finally reading "patient entered." 96 Patients were then sent to the triage room where they were assessed. Nursing Sisters worked in the Emergency Room and Triage Room, while nursing students and Teaching-Sisters took care of those overcome by tear gas and those suffering minor cuts and bruises.

93 Ibid, 16, 22.

94 "She heard the whistles and sirens and knew instinctively. . ." Sisters of St. Joseph Rochester Newsletter (Summer 2000), 3. Author's collection.

95 Lum Interview.

96 "Good Samaritan Log Book", March 7, 1965. Society of St. Edmund (SSE) St. Elizabeth 
John Wright was at home with his children that Sunday and was immediately summoned to the hospital by phone. He recalls the irony of the situation at Good Samaritan that afternoon.

Here you have this dramatic moment of the marchers being cared for by primarily segregationist mindset white doctors, giving them truly professional care, but at the same time arguing the philosophy of was this right or not. 97

Sisters Lum remembered one of the white doctors saying to each of the men and women he treated, "I know that it's outside agitators. I know you would not cause this kind of trouble. I know you would never want to be involved in this mess. I know it's outside agitators." For Lum the interaction of the black wounded protesters and white segregationist doctor was "symbolic of the great rift in perception" that divided white and black Selma. 98

The tear gas greatly added to the confusion, as it soon was affecting both patients and caregivers. Sisters Geck described the difficulty of working in such conditions:

It was on people's clothes. It was everybody's clothes. It was a small room with no ventilation, and you had to just wash your hands, wash your eyes, blow your nose and get back to work. ${ }^{99}$

In addition, there were numerous fractures and severe head lacerations, the result of blows to the head with billy clubs or from being trampled by horses. Sisters Weaver described one of the patients, who had gotten down on the

Selma Mission Archives (SEMA).

97 Wright Interview.

98 Lum Interview.

99 Geck Interview. 
ground to protect her granddaughter form marauding posse men. The mounted deputy had charged her and brought his horse down on her, breaking her ribs. 100 patients were treated and released, and 15 were admitted overnight. The Sisters returned home to the convent just past two in the morning.

Ouellet and McNeice drove around Selma collecting the wounded and trying to maintain nonviolent discipline. The two priests picked up the bloodied and battered and took them to the hospital. They also investigated many of the rumors that were flying around the city. Sisters Lum remembers having heard that two black youths had disappeared. The youths were located once the situation settled down. But, with all that had happened, Lum remembered, "there was enough chance that anything could be true."100

Ouellet returned to the mission Sunday evening, to offer Mass. For him the day's events were reminders of Christ's sacrifice on the cross. For the priest the blood of the marchers was inextricably linked to that of Christ on the cross. Ouellet later related the emotional toll of having carried bloodied and battered men, women and children to the hospital to Monsignor Daniel Cantwell of the Chicago CIC. Cantwell recalled:

He told us of a teenage girl who was brought in from the bridge...badly injured and bleeding. He picked her up, and as he carried her into the hospital felt that in his arms was his own child, bleeding and crying, seriously hurt. Before long her blood was on his coat and on his hands, and when he wiped of his face, then on his face. Broken, distressed, he knew how precious was this blood, but he knew more; he knew that afternoon on

100 Lum Interview. 
the bridge Christ's blood was poured out again, and that the blood on his face was the blood of Christ. ${ }^{101}$

Ouellet explained that during the Mass, as he lifted the chalice, he wept.

Cantwell recalled, "For him it was obvious that the bridge was a new Golgotha; all the elements of the initial Calvary were there, -- the cruelty, the violence, the bloodshed, Christ's blood was poured out again, and in His members he was put to death." 102

101 Daniel Cantwell, "To Witness," Friendship House Newsletter CUAA George Higgins papers Box 129, File 131.

102 Ibid. 


\section{Chapter 9 : "Outside Agit ators."}

"I'm the local agitator. Glad to have you outside agitators."

Brother McGinnis, S.S.E.

National television and newspaper reporters captured the entire attack on the Edmund Pettus Bridge. Camera crews and photographers were stationed within a few yards of the troopers when the assault began. That night a news bulletin interrupted ABC's "Sunday Night at the Movies" presentation of Judgment at Nuremberg and showed extensive footage of the attack. ${ }^{1}$ George Leonard saw the footage that evening and was inspired to travel to Selma. He recalled the impact the images had upon him:

A shrill cry of terror, unlike any that had passed through a TV set, rose up as the troopers lumbered forward, stumbling sometimes on the fallen bodies ... Periodically the top of a helmeted head emerged from the cloud, followed by a club on the upswing. The club and the head would disappear into the cloud of gas and another club would bob up and down ... Unhuman. No other word can describe the motions ... My wife, sobbing, turned and walked away, saying, "I can't look any more."2

SCLC's Andy Young noted, "The violence in Selma was so similar to the violence in Nazi Germany that viewers could hardly miss the connection."3 Almost immediately it was being referred to as "Bloody Sunday" and national attention, the kind SCLC and SNCC had hoped might inspire federal legislation, was

\footnotetext{
1 Garrow, Protest at Selma, 78.

2 Ibid, 84-85.

3 Young, Easy Burden, 358.
} 
riveted upon Selma. Later that evening King issued a statement asking for support.

In the vicious maltreatment of defenseless citizens of Selma, where old women and young children were gassed and clubbed at random, we have witnessed an eruption of the disease of racism, which seeks to destroy all America. No American is without responsibility. . . The people of Selma will struggle on for the soul of the nation, but it is fitting that all Americans help to bear the burden. I call therefore on clergy of all faiths to join me in Selma for a minister's march to Montgomery on Tuesday morning, March ninth. ${ }^{4}$

The unprecedented response to King's call altered the civil rights movement, the Catholic Church, and the nation itself.

The following day the attack at the bridge made the front page of every newspaper in the country. ${ }^{5}$ Pressure was quickly brought to bear on Congress, the Justice Department and President Johnson to force a government response to the violence. Demonstrations were planned in numerous cities across the country, including Washington, New York, Boston and San Francisco. Within hours of King's plea for help, groups of every denomination and affiliation and ranging from laity to the highest-ranking clergy were pouring into Selma. John Wesley Lord, Methodist Bishop of Washington, D.C., arrived on Monday night and explained his involvement to the press in terms of Christian witness: "I heard that Dr. Martin Luther King was calling for white ministers to come and march, and I am a white minister. You can say that I heard the Macedonian call. We

\footnotetext{
4 King statement cited in Fager, Selma: 1965, 98.

5 Roy Reed, "Alabama Police Use Gas and Clubs to Rout Negroes," New York Times, March 8 , 1965. Leon Daniel, "Tear Gas and Clubs are Used, Scores of Negroes Hurt; King Calls for Another Try," Washington Post, March 8, 1965.
} 
heard the voice of God from Selma and we came." Catholics would describe their participation in similar terms.

Matt Ahmann walked up the five flights of stairs to the NCCIJ office Monday morning and called his staff together. He had seen the footage of the assault broadcast on Sunday evening and realized that this was an opportunity for the fledgling NCCIJ to mobilize Catholic participation. In his eyes, Selma became the first test of the resolve and willingness of Catholics to participate as full-fledged members of the movement. NCCIJ staffer, Sisters Mary Peter, recalled:

I don't remember NCCIJ being involved like this before. This was very spontaneous. [I remember] Matt Ahmann walking upstairs . . .and saying, "We have to do something. We have to do something." I was next to his office and he said, "Call the nuns and we'll get in touch with the CICs." ${ }^{6}$

The connections that NCCIJ had made three years earlier at the Conference on Race and Religion and the March on Washington made them the primary Catholic contact for SCLC and on Monday, the NCCIJ received a telegram from SCLC headquarters in Atlanta requesting Catholic participation. The Conference sent telegrams to every one of its 110 affiliates, as well as women's religious orders, to rally support for Catholic involvement. Ahmann also called a number of key dioceses and the Social Action Department of the National Catholic Welfare Conference.

The logistical problems in sending such a large and widespread group

\footnotetext{
${ }^{6}$ Sisters Mary Peter later reverted to her given name, Margaret Traxler. Margaret Traxler
} Interview by author. 
were enormous. The NCCIJ began contacting airlines to book or charter flights to Montgomery. Meanwhile, Ahmann contacted Ouellet for the first time. The two men agreed that NCCIJ would relay all the information about flights and arrivals of all of the Catholic delegations to Selma, and the mission staff would arrange to meet them at the airport and take them to St. Elizabeth's. That afternoon Ahmann and a small staff flew to Selma and established a temporary NCCIJ office in St. Elizabeth's parish hall to coordinate Catholic involvement. The Conference planned to keep both the Selma and Chicago offices open seven days a week for the duration of the demonstrations. A six-telephone command post in Chicago coordinated the continuous movement of Catholics into Alabama from five areas of the country with the temporary office in Selma. ${ }^{7}$ The results of the NCCIJ's efforts were both effective and precedent shattering. By Monday evening groups were pouring into Selma.

The first Catholic delegation to arrive was from Washington, D.C., led by Father Geno Baroni. Baroni, the pastor of the integrated Sts. Paul and Augustine Church in Washington, had participated in protest before, mostly picket lines at the Capitol in support of civil rights legislation. But he had never been involved in direct action demonstrations. Having seen the footage of the attack on the bridge Sunday night as he watched Judgment at Nuremberg, he thought:

My God, this is my country. This is my time. I couldn't look the other way as the Nazis did in Germany. I wanted to cry. I wanted to scream. I knew I had to do something."8

7 Matthew Ahmann, "Newsweek Memorandum," March 22, 1965. NCCIJ Papers. MUA.

8 Lawrence O'Rourke, The Life and Mission of Geno Baroni, (New York: Paulist Press, 1991), 44. 
Baroni and Floyd Agnostelli, a layman who worked in the diocesan chancery office, asked Archbishop Patrick O'Boyle for permission to lead a delegation to Selma. O'Boyle agreed so long as it was limited to four priests-- no nuns. He stipulated the clergy wear black clerical garb and Roman collars the entire time to avoid trouble and specified that the delegation clear their presence in Selma with the local ordinary, Archbishop Toolen.

Abiding by this protocol had seriously limited the ability of Catholics to participate in civil rights demonstrations in diocese where the local bishop's did not support the movement. Agnostelli knew that Toolen would never give permission, but he was unable simply to ignore O'Boyle's request. He decided a feigned attempt at contacting the archbishop would suffice. He instructed his secretary, Joan Briscoe, to phone Toolen in Mobile with the request, knowing full well that Toolen was in Washington attending a meeting. With O'Boyle's final precondition satisfied, Baroni, Monsignor George Gingras, the Archbishop's advisor on racial issues, and two other priests hastily packed and left for National Airport to catch a plane chartered by the Episcopal church's delegation.

When Toolen was told of the request and that it had been directed to his office in Mobile, he was incensed. He immediately ordered his secretary to call Agnostelli and make his refusal clear. Agnostelli left his office and took a long lunch. Briscoe, after stalling for almost an hour, eventually misinformed Toolen's secretary that the Washington delegation was leaving for Selma from Dulles Airport. While Baroni and Gingras were being paged at Dulles, the delegation 
left for Selma.

Agnostelli quickly relayed the news of O'Boyle "granting permission" for the Washington delegation to the NCWC and Matt Ahmann at the NCCIJ. Ahmann used the Washington example to prod other bishops into allowing groups from their dioceses to participate. "For the first time," Ahmann recollected, "priests with authorization from their bishops marched in support of voting rights." Ahmann later credited the Washington delegation with playing an important role in spurring Catholic participation. "Whatever the details are on Archbishop O'Boyle," Ahmann said, "if he had not given his priests the O.K. to go to Selma there would have been far fewer Catholics there. I think his leadership in this act was crucial."10

Support for Catholic participation among the hierarchy varied widely. Archbishop Robert Lucey of San Antonio received a call from some of his priests requesting permission to go at 10:00 p.m. Monday evening. Lucey gave his priests permission and told them to "go with his fervent blessing."11 Cardinal Francis Spellman of New York, Archbishop Thomas Connely of Seattle, and Archbishop Joseph McGucken of San Francisco gave their unconditional support

\footnotetext{
9 The complete account of the Washington D.C. delegation is recounted in O'Rourke's, Geno, 4650. Note: O'Rourke mistakenly identifies Ahmann as the Secretary of the Catholic Interracial Conference (cf: 50).

10 Matthew Ahmann, "Telegram to Edward Keating," May 13, 1965. NCCIJ Papers. MUA. Keating was the editor of the Catholic Weekly Ramparts.

11 "Florentine Fanfare/Catholics at Selma," March 20, 1965. The Brooklyn Tablet, 332.
} 
to the participation of clergy and religious a few days later. ${ }^{12}$ Most bishops, if they did not give unconditional support, gave tacit support because they did not want to become entangled in an inter-episcopal war with Toolen. Archbishop Joseph Ritter of St. Louis did not officially sanction the activities of his priests and said that they "were mature enough to make their own decisions on involvement in Selma and that he admired them for going."13

Archbishop James McNulty of Newark allowed a small delegation to go, but refused to issue a public statement of support. Instead he thought a "silent witness might be more meaningful." 14 Similarly, Bishop of Akron did grant permission to go, but made no public statement regarding the matter. The Akron $\mathrm{CIC}$ called all the priests in the area to tell them bishop had granted permission, but only a few priests in the diocese took part in the marches. ${ }^{15}$ Several Charleston priests asked for permission to go to Selma and were denied. Msgr. Joseph Bernadin, chancellor of the diocese, denied the request after he checked with Archbishop Toolen. ${ }^{16}$ Bishop Ernest Unterkoepfler of Charleston was more conscious of offending Toolen, as well as his own Southern white parishioners,

\footnotetext{
12 "Priests, Nuns Say They Belong in Rights Drive: Alabama Archbishop Dissents," The Catholic Universe Bulletin March 26, 1965 vol. 9 no. 50 (), 1.

13 "Telegram from NCCIJ Field Representative to Matt Ahmann," March 19, 1965 NCCIJ Papers. MUA. The author of the telegram is identified as Tom.

14 Rev. John Catoir, "Participation List for Patterson N.J.," March 30, 1965. NCCIJ Papers. MUA. 15 Rev. Thomas R. Gallagher "Participation List for Akron CIC," March 26, 1965. The letter identified the Rev. Thomas Gallagher, Chaplain Akron CIC and Father Edward Griffen, an assistant at Holy Family Parish in Cleveland, as the only other priest from the diocese who marched.

16 Jack Sisson, "Telegram to Matthew Ahmann," March 17, 1965. NCCIJ Papers. MUA. Bernadin was later archbishop of Chicago and a Cardinal.
} 
and refused to grant his clergy and religious permission. The Bishop of Portland Oregon also denied permission for priests to participate. ${ }^{17}$

Archbishop Paul Hallinan of Atlanta consulted Father John Cronin, Director of the Social Action Department at NCWC, and Bishop John Spense, Vicar General for Lay Organizations of the Archdiocese of Washington D.C. Hallinan claimed that he feared for the physical safety of his priests. ${ }^{18}$ However within a few days, he changed his mind and allowed priests and laymen to go with his approval. After the demonstrations Hallinan made it clear that "no money of the Archdiocese was ever used; those who went defrayed the small expense out of their salaries."19 He asserted "the Church will probably take part in demonstrations again, if the cause is right and the necessity urgent." As long as the demonstrations remained non-violent and those who chose to participate did not neglect their pastoral responsibilities, the archbishop saw no problem. Nonviolent demonstrations, he said, "can be acts of virtue. If the cause is righteous and the result is vital, Catholics may take part." 20

The New York Catholic Interracial Council delegation included three African American priests and went to Alabama "with the approval and blessing" of the New York Catholic Archdiocese. The group left John F. Kennedy airport early Monday for Montgomery. Father John Dugan led the delegation. He

\footnotetext{
17 William McCoy, "Portland (OR) Participation List." March 14, 1965. NCCIJ Papers. MUA. 18 Jack Sisson, "Memo on Archbishop Hallinan's Position," March 11, 1965. NCCIJ Papers. MUA. 19 Religious News Service, "Letters 2-1 in Support of Religious Activity at Selma" March 31, 1965. Catholic Peace Fellowship Papers. University Notre Dame Archives (UNDA). 20 Ibid.
} 
declared that this "is a moral question, and we are moral leaders. We hope

that by our presence in Alabama we will encourage the people of Selma to keep

up the struggle for equal rights." 21

By Tuesday Catholic Interracial Councils were making plans to bring

delegations to Selma from Ann Arbor ${ }^{22}$, Baltimore ${ }^{23}$, Boston ${ }^{24}$, Chicago ${ }^{25}$,

21 "City Sends 30 Priests Into Selma," Journal American. March 15, 1965. Twenty-eight priests and four laymen went to Selma to protest racial injustice in the city. Rev.. Lawrence F. Lucas of St. Charles, Borromeo Parish, Catholic News Correspondent; Msgr. Owen Scanlon, St. Charles Borromeo; Rev.. Edward T. Dugan, Resurrection; Rev. Donald J. Johnston, Incarnation; Rev. Harold A. Salmon, Cardinal Hayes High School; Rev. Matthew M. Thompson, Cardinal Hayes High School; Rev. John J. Rossi, St. John Chrysostom; Rev. Edwin J. Conlin, Holy Family; Very Rev.. Msgr. James F. Cox, Rockland State, Hospital; Rev. Willard Kean, Rockland State Hospital; Rev. Alfred R. Guthrie, St. Matthew; Rev. John Flynn, St Raymond; Rev. Robert B. Weinheimer, Our Lady of the Assumption; Rev.. Kenneth F. O'Connell, Sacred Heart; Rev. Gerald J. Ryan, St. Anthony of Padua; Very Rev. Msgr. Robert J. Fox, director, Spanish Catholic Action; Rev.. Patrick J. McCormick St. James; Rev. Peter Gavigan, St. Theresa; Rev. Daniel J. Berrigan, S.J., Jesuit Missions; Rev. John F. Matuseviscius, St. Matthew; Rev. Dennis Murphy, SJ. St. Anthony of Padua. Rev. Paul Banet, S.S.J., Bronx; Rev. Philip Berrigan, S.S.J., Epiphany College. The laymen were: Tom Murray, St. Mary's Newburgh Community Action: John Grady, St. Charles Borromeo, Drew Foundation; Thomas Cornell, Catholic Worker; Eileen Egan, Catholic Relief Services, NCWC.

22 The Ann Arbor Delegation: Mr. Paul Bekulich, Rev. John Clark, Mr. Kenneth Gaertner, Mr. Timothy Gregory, Mr. Robert Hooper, Rev. Patrick Jackson, Mr. Glen Johnson, Mr. Paul Melton, Mr. Keith Nelson

23 The Baltimore Delegation: Rev. John Gray, Shrine of the Little Flower, and Rev. Joseph Connolly, St. Gregory's.

24 The Boston Delegation: Rev.. Thomas J. Carroll, Catholic Guild for the Blind; Rev.. Francis McDonnell, Rev. Walter McDonough and Rev. Robert Baer, C.S.P. A small group from New Hampshire also traveled with the Boston Delegation: Rev. Samuel McCain Jr., Newport; Rev. Parkman D. Howe, Concord; Dr. Samuel Bachrach, Worchester; George Parker, Mattapan; Mrs. Robert Hallgring, Newton Highlands; Francis X. Hurley, Winchester; and Barbara Cort, the Newton Center, also the daughter of John Cort, director of the State Service Corps and former labor reporter for Commonweal.

25 The Chicago Delegation (included the NCCIJ, Chicago CIC and Evanston delgations): Sr. Mary Michael, Bro. Carl, Sr. Michael Zatopa, Sr. Mary Catherine, Sr. Mary Raynold, Sr. Rose Walter, Sr. Rose Michael, Sr. Mary Peter Traxler S.S.N.D., NCClJ; Sr. Mary Benet, Rev. JohnBarlow, Rev. Alban Berling, Mr. Emery Biro, Ms. ElaineBlas, Mr. James Bonner, Rev. Francis Bonnike, Mrs. Madelaine Bonsignore, Mr. Jim Boris, Mr.Wally Bradford, Rev.John Brennan, Rev. Kenneth Brigham, Mr. Tim Buckley, Mr. George Bussey, Msgr. Daniel Cantwell, Chicago CIC, Ms. Grace Carroll, Rev. John Cavanaugh, Ms. Frances Chapman, Rev. George Clements, Rev. John Coffield, Ms. Dolores Coleman, Mr. Tom Cook, Dr. John Coons, Mr. Jim Davy, Mr. Sam Dennis, Rev. James Doyle, Rev. Jerome Du Charme, Rev. Ralph Dunlop, Mrs. Alfred Dziuk, Msgr. John Egan, Rev. John Eichleman, Mr. Elson Elden, Mr. Jerome Ernst, Mrs. Hermine Evans, Ms. Donna Glieyner, Mr. D. Goodwin, Rev. William Graney, Rev. Richard 


\begin{abstract}
Columbus ${ }^{26}$, Covington ${ }^{27}$, Detroit 28, Hartford ${ }^{29}$, Houston ${ }^{30}$, Kansas City ${ }^{31}$,
Milwaukee ${ }^{32}$, Minneapolis/St. Paul33, New York ${ }^{34}$, Oklahoma City35, Patterson ${ }^{36,}$
\end{abstract}

Grimm, Ms. Arletta Hartman, Msgr. John Hayes, Mr. Frank Hilkin, Rev. William Hogan, Rev. John Jerbi, Msgr. Kennedy, Rev. William Knott, Mr. William Kruse, Mr. Mike Lawson, Ms. Virginia Leary, Mr.Thomas Mack, Rev. Daniel Mallette, Rev. Owen McAtee, Mr. John McDermott, Rev. Tom Millea, Rev. Gerald Millin, Rev. Ralph Mollan, Rev. Francis Moskal, Rev. Michael Nallen, Mr. Al Nellum, Mr. Don O'Connell, Bro. Jack Reardon, Mr. Philip Ripp, Rev. Phil Ripp, Ms. Peggy Roach, Mr. Clifford Rogers, Ms. Betty Ryan, Mr. Donald Servatius, Mr. Dan Shay, Bro. Gordon Simmons, Ms. Denise Snyers, Ms.Connie Tarsa, Rev. Anthony Vader, Mr. Robert Vondrasek, Rev. Gerry Weber, Rev. Spencer Wilson, Rev. Boniface Prater, Mr. John Landgraf, Mrs. Betty Plank, Mrs. Lynn Williams, Mrs. William Burke, Rev. Gregory O'Brien, Rev. Thomas McDonough, Rev. Joseph Fichter, Mr. Matthew Ahmann, NCCIJ; Rev. Richard Valker, Ms. Pamela Payne, Ms. Daren Puchalski, Ms. Henrietta Humble, Ms. Bonnie Rochetto, Ms. Carol Watterman, Ms. Pat Mulryan, Ms. Charmaine Hill, Ms. Cecelia Woloski, Ms. Kayellen Hartman, Ms. Judy Stephanie, Ms. Faye Turner, Ms. Bonnie Scrobley, Ms.KathyReily, Ms. Brenda Dineen, Ms. Jo Ugolini,Ms. Regina Johnson, Ms. Helen Moorhead, Ms. Carol Dahany, Ms. Adrienne Bailey, Ms. Catherine Simmeron, Ms. Pam Meadows, Ms. Ann Murphy, Ms. Judith Hilkin, Ms. Pat Willging, Ms. Pat Kurauski, Ms. Mary Reser, Ms. Erma Neal, Ms. Sandra Charles, Sr. Mary Georgia, Sr. Mary Irma, Sr. Mary Sharon, Sr. Mary Irene, Sr. Mary Donatus, Sr. Mary Ignatia, Rev. Mullahey, Dr. Charles Abildgaard, Mrs. Milton Mozen, Rev. James Mollohan, Rev. Frank Slobig.

26 The Columbus Delegation: Rev. August L. Win, Vincent M. Rizzotto, Rev. John McCarthy, Rev. Joseph Fiorenza, Rev. Dayton Salisbury, Rev. William M. Pickard, Rev. Charles Ternes, Rev. Gerald Walker, Rev. Maurice Farge CSB, Rev. John Sheehan CSB, Mr. Edward Roberts student University of St. Thomas; Mr. Martin Buckley, a student at the University of St. Thomas; and Miss Catherine Holman.

27 The CIC of Northern Kentucky Delegation: Rev. Thomas Middendorf, National Director of Retreat Movement; Rev. Anthony Deye, Professor of History at St. Pius X Seminary; and Rev. William Poole, of Lexington.

28 The Detroit Delegation: Mrs. Maureen Bush, Detroit CIC; and Sisters Christelli, I.H.M.

29 The Hartford Delegation: Rev. Alfred Jaenicke, St. Michael's; Rev. Robert D. McGarth, St. Michael's and Rev. Tartaglia.

30 The Houston Delegation: Mr. Martin Buckely, Rev. Maurice Farge, Rev. Jospeh Fiorenza, Ms. Catherine Holman, Rev. John McCarthy, Rev. William Pickard, Rev. Vincent Rizzotto, Mr. Edward Roberts, Rev. Dayton Salisbury, Rev. John Sheehen, Rev. Charles Ternes, Rev. Gerald Walker. 31 The Kansas City Delegation: Very Rev. Msgr. Victor G. Moser, Spiritual Moderator of Kansas City CIC and president of the Greater Kansas City Council on Religion \& Race; Rev. Rene Gusnier, O.S.B., St Aloysius Parish; Sr. Mary Leoline, B.V.M., Principal Christ the King School; Rev. Richard T. Saale, Pastor Blessed Sacrament Church; Rev. Norman Rotert, Asst Pastor, Annunciation Parish; Rev. John Cole, St Louis Parish Assistant Superintendent of Schools; Rev. Alfred O'Laughlin, St. Peters Parish; Rev. Arnold Blaes, O.S.B., St Peters Parish; Sr. John Christine, M.M., Queen of the World Hospital; Sr. Madeline Marie M.M., Queen of the World Hospital; Sr. Winifred Mary Notre Dame de Sion, Sr. Raffaela Notre Dame de Sion, Sr. Ann Benedict SSJ, Sr. Joan Therese SSJ, Sr. Judith Mary, S.L., Loretto Academy, Sr. David Maureen, S.L., Loretto Academy, Sr. Mary of the Redemption SOC of Our Lady, Sr. Mary of the Incarnation SOC of Our Lady, Sr. Mary Gregory of the Diocesan School Office Sisters of Charity Leavenworth, and Avia College Students; Mary Kay Ross and Martha Machovec.

32 The Milwaukee Delegation: Racine Nuns: Sr. Christopher, a teacher at Dominican College in Racine; Sr. Gerhard, a teacher at Racine St. Catherine High School; Rev. Matthew Gottschalk, 
Philadelphia, Pittsburgh, Portland, St. Louis ${ }^{37}$, San Antonio38, San

Francisco ${ }^{39}$, Syracuse ${ }^{40}$, Toledo ${ }^{41}$, Washington ${ }^{42}$ and Youngstown ${ }^{43.44}$ Initially

Rev. Austin Schlaefer, Rev. James Groppi, Patrick Flood, and Msgr. Franklyn Kennedy, editor of the Catholic Herald Citizen; and Sr. Mary Jeanine, Sr. Ann Frances, and Pauline Turner, instructor of theology at Marquette University.

33 The Twin Cities Delegation: Rev. Thomas Conroy, Bro. DePaul, Ms. Pat Donohue, Mr. Joseph Donohue, Rev. Egan, Rev. John Forliti, Rev. Thomas Garvey, Mr. Thadeus Gierymski, Rev.

Edward Grzeskowiak, Mrs. Bernard Lang, Rev. Anthony Lewis, Rev. Paul Mohrbacher, Mr. Paul Sontag, Rev. Godfrey Diekmann

34 The New York Delegation (includes the Brooklyn, Long Island and Rockland County Delegations): Rev. William Hogan, Rev. George Clements, Msgr. Daniel Cantwell, Chaplain of the Chicago Catholic Interracial Council; Rev.. Jerome Ducharme, Rev. John Jerbi, Rev. Gerald Millin, Rev. Owen McAteer, Rev. Daniel Mallette, Sr. Mary Raynold, Rev.. Michael Nallen, Bro. Jack Reardon, Bro. Gordon Simmons, Rev. John Brennan, Rev. Kenneth Brigham, Rev. William Graney, Msgr. John Hayes, Rev. John Eichleman, Rev. Ralph Mollan, Rev. Francis Moskal, Sr. Mary Peter, S.S.N.D., NCCIJ; Sr. Mary Benet, Sr. Rose Walter, Rev. James Mollohan, Rev. Thomas McDonough, Rev. Joseph Fichter, Rev. Gregory O'Brien, Rev. John Coffield, Rev. John P. Henry, Diocesan C.Y.O. Director; Sr. Maria Eucharia CSJ, Sr. Thaddeus CSJ, William Goddard of the Long Island Catholic, Mrs. Wesley J. Rowcroft, Vice President and Executive Secretary of CIC of Long Island. Note: Father Coffield was a diocesan priest from Los Angeles who left on a three-year leave of absence after publicly criticizing Archbishop James Cardinal Mclntyre for what Coffield called the archbishop's "evil of silence" on racism. See "Scores of City's Clergy Join in Alabama Effort." March 15, 1965. Chicago Daily News.

35 The Oklahoma City Delegation: Rev. Daniel Allen, Rev. Robert McDole, Rev. J. Donavan, Rev. Paul Gallatin, Mr. Edward Kelly, Rev. Edmund Kelly, Rev. Robert McDole, Rev. James McGlindieg, Rev. William Rath, Rev. John Vrana

36 The Patterson Delegation: Rev. John Simonet, Mr. James Lamb, Director of A.I.D.; Rev. John Catoir, the CIC of Patterson

37 The Saint Louis delegation included: laypersons Roy Albeseverty, Richard Childress, John Elliot, Ken Hensiek, Dr. John Higgins, Thomas Gibbons, Thomas Gibbons III, Paul Hanlon, Jerome Holden, William Meade, Mrs. Rois, Charles Vatterott, Jr., Msgr. James Curtin and Rev. Jerome Brzakowski, Rev. Robert Courver, Rev. Gerald Curtin, Rev. John Daly, Rev. Francis Doyle, Rev. Carl Dudley, Rev. Paul Harting, Rev. George Hendel, Rev. Robert Krawinkel, Rev. John Lightle, Rev. Robert McCann, Rev. E. O'Donnell, Rev. A. Peet, Rev. Robert Peet, Rev. John Shocklee, Rev. James Schumacher, Rev. Lloyd Sullivan, Rev. Bruce Vawter, Rev. David Wichlan, and Rev. Aloysius Wilmes. Sr. Thomas Marguerite, C.S.J., and Sr. Ernst Marie C.S.J., both professors of sociology at Fontbonne College, Sr. Eugeen Marie, Sr. Ann Christopher, S.L., Sr. Mary Antona, S.L., Sr. Christine Mary, S.L.

38 San Antonio Delegation: Rev. Sherrill Smith and Rev. Lawrence Murtagh went as Archbishop Lucey's personal representatives to the Reeb memorial on Monday March 15.

39 San Francisco Delegation: Laywomen Gertrude Behan and Mary Connoughton, and Rev. Tomothy Monohan, St. Simon's.

40 Syracuse Delegation: Msgr. Charles Brady led the delegation, Rev. Edward Hayes, Rev. Thomas Costello, David W. Barry Foundation, Rev. Charles Fahey, Rev. J. Elwood, Rev.Charles Eckerman, Rev. Thomas McLaughlin, Rev. Walter Denero, Sr. Robert Joseph, Sr. John Joseph, Mr. William Chiles, Ms. Mary Klein, Mr. Jerome Berrigan, Dr. John Brule, Dr. Frank Durgin, Rev. Donald Bauer, Our Lady of Lourdes Church. 
Catholic participants at Selma did not discuss the question of authority

widely. It was not an issue they chose to deal with during their stay. Ouellet

recalled being asked only once if the ordinary had approved of the

demonstrations:

I remember a priest from the Hartford diocese came up to me and asked, "what was Bishop Toolen's stand on this. We shouldn't be doing anything he doesn't want us to do." I said, "You're the first person who has asked that and if it is really a concern for you, you probably shouldn't be here." And that was the end of that. ${ }^{45}$

Ahmann remembered that Toolen sent a priest to investigate the situation in Selma. ${ }^{46}$ But many activists were simply unaware of Toolen's antipathy toward demonstrations. The archbishop did not issue a public statement regarding the assault on the bridge nor the presence of Catholics in the demonstrations until Thursday March 18.47 "I don't think there would have been any way to stop [Catholics from coming]," Ahmann recalled. "I think that [Toolen] was smart enough to realize that. We were never faced with that question. In any case we

\footnotetext{
${ }^{41}$ Rev. Bernard J. Boff, Rev. Robert J. Armstrong, Rev. Robert J. Drouillard, and Rev. John E. Lester marched on March 15, 1965.

42 Washington D.C. Delegation: Rev. Geno Baroni, Msgr. George Gingras Rev. Joseph Haslinger, Rev. Gerald Horgan Mr. Walker Johnson, Rev. George Joyce Bro. Leo Kiley, Mr. Henry Leake, Rev. John McBride, Rev. Richard McSorely, Dr. Llewellyn Scott, Rev. George Spellman, Mrs. Marie Cotes

43 Youngstown Delegation: Rev. Donald Bank, Mr. Edgar Barmann, Mr.Dennis Finnernan, Rev. Ralph Friedrich, Rev. John Gallagher, Rev. Joseph Koch, Rev. Richard Konkel, Rev. Thomas McCarthy, Msgr. Paul O'Connor, Rev. Stewart Platt

44 The NCCIJ surveyed all its affiliate organizations as well as the chancery office of each diocese in order to account for all those who participated in the demonstrations. The information regarding which councils, orders and diocese which were represented are from these letters. The letters are located in the Selma Correspondence files, NCCIJ Papers MUA.

45 Ouellet Interview.

46 Ahmann identifies the priest as Father Foster, the diocesan supervisor of education.

47 Lipscombe Interview.
} 
would have had to break it." 48

Many simply came without the consent of their superiors. To surmount the problem of episcopal authority, many delegations simply did not ask permission of their superiors and the local ordinary, ignoring the protocol altogether. For them, Selma was a matter of individual conscience outweighing any episcopal considerations. The Rev. Daniel Mallette, pastor at St. Agatha's parish in Chicago, traveled on his own to Selma and sought no permission. ${ }^{49}$ The Rev. Richard Sinner of North Dakota had been involved in interracial activities for a number of years, and had sponsored groups of priests and laymen in SNCC's 1964 Freedom Summer project. He also sought no permission to march in Selma. 50 Others, like the Rev. James Cox, President of the Rockland County $\mathrm{CIC}$, who traveled to Selma with the New York delegation, had not bothered to check with his superior before he left even though Cardinal Spellman had given permission. ${ }^{51}$

SCLC's plan was to seek a court order from U.S. District Court Judge Frank Johnson, to restrain the state and county officials from using excessive force and to guarantee the demonstrators the right to march to Montgomery. Johnson had been a supporter of civil rights since King's first encounter with him during the Montgomery Bus Boycott in 1955. But he was also a man who went

\footnotetext{
48 Ahmann Interview.

49 Daniel Mallette Questionnaire. Mallette had been picketed with the nuns at the Loyola Towers in 1964.

50 Ralph Sinner Questionnaire.

51 James Cox Questionnaire.
} 
by the book. The judge refused to issue an injunction without first holding hearings, ruling "there would be no irreparable harm if the plaintiffs waited for a judicial determination of the matter involved." He scheduled the hearings to begin Wednesday, March 10.52 No marches were to take place in the interim.

To this point King had carefully abided by Federal court decisions because he considered the Federal courts to be one of the movement's few allies. King was placed in an extremely awkward position, as he did not want to defy a federal judge. Initially organizers planned to abide by the order, but at the last minute King announced that the march would proceed. There were an estimated three thousand demonstrators from across the United States and Canada in Selma who had come specifically for the Tuesday march. No one was sure how long this level of participation, and the media attention that it generated, would last. Organizers needed to take advantage of the situation before support waned.

SCLC began frantic negotiations with city, state and federal officials. Attorney General Nicholas Katzenbach spoke with King on the phone and asked him to hold off until Wednesday. ${ }^{53}$ Leroy Collins, former Florida Governor and Director of the Community Relations Service, flew in to Selma early Tuesday morning to broker a deal. A secret agreement was reached between Collins, King and state officials, in which King would lead a march to the bridge, assert

52 Johnson quoted in Fager, Selma:1965, 101.

53 Garrow, Protest at Selma, 85. Hosea Williams was the only SCLC official who supported marching, all other leaned towards canceling the proposed Tuesday march. 
the group's right to march, pray, and return to Brown's Chapel. ${ }^{54}$ Sisters Mary Paul requested that the Sisters in Rochester offer prayers for the mission. "Another March is planned by the colored, reinforced by more than 100 clergymen from the North of all denominations," she wrote. "Please pray that there will be no violence or bloodshed." 55

Despite the coordination efforts of the NCCIJ, the mission staff was not prepared for the large number of demonstrators that came to the city. Sisters Mary Paul Geck described the shock the Sisters experienced when they realized the extent of the participation. "We didn't even know they were all going to come," she recalled, "All of a sudden, here they are." 56 On Sunday night Father Ouellet and Sisters Mary Paul discussed what should be done about the school. Ouellet asked that the Sisters keep the school open in order to provide as normal a life as possible for the children. The Superior in Rochester was very concerned about the situation in Selma. On Tuesday she called to ask if the convent needed extra staff---- a number of Sisters had volunteered to go to Selma. Sisters Mary Paul Geck declined the offer. She explained the situation was under control and that the Sisters were able to take half days off. However, if new staff were to be sent, all of the Sisters' free time would be spent acclimating the new arrivals. ${ }^{57}$

\footnotetext{
$54 \mathrm{lbid}, 1002-103$. Garrow, Protest at Selma, 86. See also Garrow, Bearing the Cross, 403. 55 "Call for Prayers," Memorandum Motherhouse of the Sisters of St. Joseph Rochester March 9, 1965. SSJA. G13-1-1/History-Establishment of Mission 8A.

56 Geck Interview.

57 Ibid.
} 
St. Elizabeth's was the command center for Catholic participation.

"The phones rang all night: How do we get there? Are there accommodations? . . . Get to Montgomery and we will meet you and fix something up." ${ }^{8}$ An arrival board was posted in the parish hall with flight information and assignments for drivers to pick up delegations. Assistant pastor Father Charles McNeice supervised the transportation of Catholics from Montgomery to Selma.

Throughout the day participants who had to leave to fulfill other commitments were dropped off at the airport, while more arrived. Some traveled with delegations whose arrival was anticipated by Ouellet and the staff, others came on their own and unannounced. Eileen Egan, who covered the demonstrations for the journal Peace, traveled from Atlanta to Dannelly Field in Montgomery with a delegation of labor leaders including Ben Siegel, Tom Donohue, Norman Hill, Leo Smith, AFL-CIO, and Charles S. Zimmerman, Vice President of the International Ladies Garment Workers Union. They were met at the airport by a member of the mission staff, Brother Anthony Maginis, S.S.E. Maginis welcomed the group, exclaiming, "I'm the local agitator. Glad to have you outside agitators." 59

At 1:30 p.m. on Tuesday afternoon the marchers, led by King, walked to the Edmund Pettus Bridge. The atmosphere was extremely tense. King had declared earlier, "Nothing will stop us, not even the threat of death itself."60 For

58 Gerald Sherry, "Dateline: Selma, Ala.," Georgia Bulletin. March 15, 1965.

59 Eileen Egan, "Turning Point in Selma," Peace, Spring 1965, 8-9.

60 King quoted in Fager, Selma: 1965, 103. 
most, this march was their first experience protest march. The potential consequences of marching suddenly became very clear as the marchers approached the site of Sunday's attack. Almost no one knew of the agreement between SCLC and the State Troopers and those who did were hesitant to put much faith in it. Most marchers expected a violent confrontation with police. At the foot of the bridge a small group of city policemen waited. A U.S. marshal read Judge Johnson's order prohibiting the march, but refused to intervene.

King asserted the group's right to march and the group proceeded across the bridge. Major John Cloud and a large contingent of state troopers and possemen were positioned on the other side of the bridge. Cloud ordered the marchers to disperse, and King again affirmed the group's right to march. King asked if he could lead the marchers in prayer, and Cloud conceded the request. The group knelt down as King and other dignitaries led them in prayer. As they did, the line of troopers parted, providing unobstructed access to the road ahead. No preparation had been made for a long march, and the agreement with the police had not included anything like this. Not wanting to call Clark and Lingo's bluff, the organizers retreated back to Brown's Chapel, ironically singing "Ain't nobody gonna turn me around." 61

A number of participants were displeased with the decision to return to the chapel. SNCC organizers, some Selma participants and many of the new arrivals wanted to confront the police and were upset with what became known

61 Fager, Selma: 1965, 103-5. See also Carson, In Struggle, 159-160. 
as the "Turnaround march." Father Geno Baroni described the feelings of "frustration and disappointment." 62 Catholics were disenchanted, not only with the march organizers and the police, but also with the lack of federal involvement. Baroni explained:

When we came over the bridge we hoped that we might find federal troops or marshals waiting on the other side to protect us. Instead, there were the state troopers. After a while you begin to wonder whether there must be brutality on the part of the authorities in every city and county in the South before the federal government will step in and protect the rights of citizens.

The danger, Baroni noted, was that many in the movement would begin to lose hope in the possibility for change and abandon nonviolence. In Selma I heard people singing 'We Ain't Gonna Be Turned Around' he recalled, "but I also remember a 16 year old boy named Maurice with a bandaged head who was singing a song that went 'There ain't no God.'”3 For Baroni, the presence of the clergy served to reaffirm the religious dimension of the struggle.

That evening in Washington White House Press Secretary George Reedy announced that the President was monitoring the situation. The President, Reedy stated, "deplored the violence" and had begun preparing new federal legislation that would guarantee the right of every American to vote. Reedy expected the bill to be completed by the weekend, at which point, the President would send a special message to Congress. ${ }^{64}$

Neither marchers nor organizers expected the demonstrations to last more

62 Geno Baroni, "...Is on Our Side: Selma, U.S.A.: Brutality," The Catholic News. 3.

63 Ibid.

64 Reedy cited in Garrow, Bearing the Cross, 405. 
than a few days, but Judge Johnson's order had prevented the march from proceeding. The tension created by the influx of protesters was left unresolved. Most participants left the mass meeting Tuesday night determined to stay in Selma for at least a few more days. One participant who chose to stay was James Reeb, a Unitarian minister from Boston. He had originally planned to return to Atlanta that evening, but at the last minute changed his mind. Reeb accompanied some friends to Walker's Café, a local African American soul food restaurant. He discussed the movement, his decision to come to Selma and the day's events with reporters Larry Still and Maurice Sorrell of Jet, James Hicks of the Amsterdam News and Mary Strattford of the Afro-American, as Sam Cook's "A Change Is Gonna Come" played on the jukebox. 65

Upon leaving Walker's, Reeb and two fellow Unitarian ministers, Clark Olsen and Orloff Miller, mistakenly turned away from Brown's Chapel. The men passed the Silver Moon Café, a notorious hangout of white toughs. As they walked down Washington Street four men attacked them. Reeb was struck in the head with a club. The attack lasted only a few moments. The three men stumbled to the SCLC office a few blocks away. Reeb was in intense pain and was immediately taken to Burwell Infirmary. Dr. William Dinkens quickly realized that Reeb needed advanced medical attention and arranged for him to be taken by ambulance to the University Medical Center in Birmingham, two hours away. Ten miles outside of the city, the ambulance had a flat tire and was delayed for

65 Tragedy Stalks King in Alabama (1965). Jet. 28-29. 
an hour before another vehicle was able to continue transporting Reeb. In Birmingham Reeb lingered in a coma, and doctors held out little hope for recovery. 66

The assault on Reeb had a powerful effect on clergy of all faiths. His participation in the demonstrations was seen as an extension of his Christian witness, and his eventual death was viewed by many as martyrdom. Many clergy who had been hesitant to travel to Selma were inspired by the minister's death. Monsignor John Egan of Chicago, a longtime Chicago CIC member and Director of the Archdiocesan Office of Urban Affairs, was recuperating from a heart attack. He had been ordered not to participate in stressful activities and was vacationing in South Carolina. Although he was aware of the demonstrations, Egan had decided not to go to Selma due to his medical condition. "When I heard that the Reverend Reeb had been beaten up," Egan said, "and that people were going to assert their civil rights, I decided to go and by my presence and witness give good example to others to stand up and be counted."67 Egan recalled that he felt personally summoned by King's call and called Chicago to ask for Archbishop Francis Cardinal Meyer's blessing. He was told that the Archbishop's only concern was for his health and that if he felt up to it he could go. He drove to Charleston and flew to Montgomery and arrived in Selma Wednesday evening. ${ }^{68}$

66 Fager, Selma:1965, 108.

67 Catholic Clergy Outnumber Others in Demonstration (1965). Southwest Louisiana Register. 68 Egan Interview and Peggy Roach Interview. 
On Wednesday, Reverend L. L. Anderson, pastor of Tabernacle Baptist church, led a group of protesters to the courthouse in order to pray for Reeb. Mayor Smitherman and Baker decided that cordoning off the demonstrators was the best strategy for preventing violence. The mayor declared the city to be in a state of emergency and banned all further marches. Baker mustered a 200-man force of state, county and city law enforcement officials. ${ }^{69}$ Baker and Smitherman met the marchers on Sylvan Avenue about 100 yards from Brown's Chapel. As the group approached, Baker informed the demonstrators "You will not march today. We have a court order forbidding it." Anderson replied, "Mr. Mayor, we are not here to rebel against your order but since we have been unsuccessful in seeking to see you we feel we have no alternative but to offer our bodies as a living sacrifice." ${ }^{\prime \prime}$ Anderson carried with him a list of the notable visitors, and each was allowed to say a few words. Monsignor Daniel Cantwell was the first Catholic to make a public statement that evening. He explained, "We stand here in the name of millions of people in the land who deplore the rise of violence and who want to repair the honor of our country before God and man."71

Various groups tried to circumvent the police barricades by taking alternate routes to the courthouse, and Baker and his officers shuttled back and forth

\footnotetext{
69 "Rights Marchers halted, Bed Down In Streets of Selma and Montgomery," Chicago Sun Times, March 11, 1965.

70 Anderson quoted in Fager, Selma: 1965, 112.

71 Eileen Egan, "Turning Point in Selma," Peace, Spring 1965, 7.
} 
intercepting marchers. ${ }^{72}$ Tension ran high as police and marchers maneuvered in and around Brown's Chapel and engaged in a game of cat and mouse. The possibility of violence on the part of the police, Clark and his deputies, state troopers or individuals was very high. And the threat of a serious breakdown in nonviolent discipline on the part of the marchers was quite real as well. The fact that so many of the demonstrators were unfamiliar with basic nonviolent techniques made a repeat of Reeb's tragic mistake extremely likely.

At the conclusion of that evening's mass meeting Abernathy announced that a march led by priests, ministers and religious was being organized to confront the authorities at the barricade. "On my right hand, said Abernathy, "will be a confrere of Jim Reeb who is dying in a Birmingham hospital, on my left hand will be Msgr. Jack Egan of Chicago."73 Another priest, aware of Egan's heart condition, offered to take his place, but Egan adamantly refused. The group proceeded outside and approached the barricades. Egan recalled:

It was the "first time l've ever been afraid, wearing a roman collar, to walk through a white neighborhood. It was the first time I've ever seen hate in the eyes of my fellow brothers or heard a policeman say, 'I'd like to put my club through that priest's skull.'"74

Egan was photographed on the line and the wire service distributed the image to newspapers across the country. Egan's fragile health was apparent. A friend of Egan's later remarked that [C.T. Vivian and Ralph Abernathy] "were holding you

\footnotetext{
72 Fager, Selma: 1965, 114.

73 Margery Frisbie, An Alley in Chicago. (Chicago: 1991) The two other ministers were Unitarian ministers Rev. Edward Blackman of Boston and Rev. Frank Anderson of Braintree.

74 Ibid.
} 
up, Jack." An editor at the Chicago Daily News recognized the priest and called Egan's parish, St. Angela's, to confirm the story. The photograph was run on the front page the next day. Hundreds of priests called both the chancellor's office and the news desk to ask if it was really Monsignor Egan. Many exclaimed, "If Jack can be there, then I can be there."75

Many of the younger marchers wanted to break through the lines in front of the Chapel and force a confrontation with Baker and Clark rather than wait for Judge Johnson's decision. "I did all I could to help," Ouellet said, "I told them who the responsible leaders were. I particularly watched over the Sisters to see that they did not jeopardize lives by acting imprudently. A couple of times I raised the roof about them being placed in dangerous situations."76 On one occasion, Ouellet appeared in the mission's V.W. bus and told the nuns that this was their "last chance to get out."77 He was concerned after a large group of whites had gathered and were shouting at the demonstrators from beyond the troopers. He counseled patience and restraint and was constantly on the lookout for breakdowns in nonviolent discipline.

Despite the determination and spirit of the marchers none were allowed to march to the courthouse. Organizers decided to hold an all night vigil at the barricade and an estimated 400 African Americans and clergymen prepared to bed down outside for the night. Baker was content to let the group remain, and

\footnotetext{
75 Peggy Roach Interview by author. John Egan Interview by author.

76 John Cogley, "Archbishop Ousts Priests at Selma," New York Times, June 26, 1965.
} 
declared they could stay there "as long as they want to."78 That evening, Baker strung a nylon rope across the area. Baker's nylon rope quickly became the object of several songs based on the spiritual "Joshua Fit the Battle of Jericho."79

As night fell it began to rain, and the marchers hastily constructed a makeshift shelter at the police barricade, and prepared to bed down for the night. Wednesday evening Ralph Abernathy contacted Ahmann and asked if it would be possible to get additional Roman Catholic priests and nuns into Selma.

Ahmann sent a telegram to all chairmen, presidents and chaplains of CICs.

Prayers needed for Justice in Alabama. I am still here. Over eighty priests from sixteen dioceses have been here. Six nuns from St. Louis led today's march. Urgently need continual flow of priests and nuns to Selma until Monday. Your help in recruiting them desperately needed. 80

Monsignor Jack Egan had an inordinate number of connections throughout the country, and Ahmann immediately put him to work on the phones. The two men spent hours trying to mobilize a Catholic response. Many who came were

\footnotetext{
77 Judith Mary, "On the Line in Selma with a Sisters Demonstrator," National Catholic Reporter, March 24, 1965.

78 "Rights Marchers halted, Bed Down In Streets of Selma and Montgomery," Chicago Sun Times, March 11, 1965.

79 The words to the "Selma Wall." Were gonna break this Berlin Wall, Berlin Wall/ We're gonna break this Berlin wall in Selma, Alabama/We're gonna stay here till it fall, till it fall, till it fall/We're gonna stay here till it fall in Selma, Alabama/Hate is the thing that built that wall, built that wall, built that wall/hate is the thing that built that wall in Selma Alabama/love is the thing that will make it fall make it fall make it fall/love is the thing that will make it fall in Selma, Alabama/we're gonna stand here till it fall, til it fall, till it fall/we're gonna stand here til it fall in Selma Alabama. Moore cites: Freedom Song 1965 Band 4 Side 1 112. See also Fager, Selma: $1965,116$.

80 Matthew Ahmann, "Prayers Needed For Justice". Telegram to all chairman, presidents and chaplains on official NCCIJ "CIC Council" List, March 11, 1965. NCCIJ Papers. MUA.
} 
personally asked to "please come to Selma" by the two men. ${ }^{81}$

The influx of hundreds of Catholics during the week placed a tremendous strain on the Mission and its staff. Few visitors were even aware of the existence of the Edmundite Mission before they arrived. One Sisters told Sisters Mary Paul Geck that she had expected "to be sleeping out in a field somewhere." 82 Eileen Egan, a reporter for Peace magazine, described the parish hall as littered with mattresses. "Priests squatted on them, while others found room at the long refectory tables. The rectory was also filled with visiting priests." 83 Ouellet told the Sisters not to board anyone at the Convent. "You Sisters, you're gonna be working hard," Ouellet told them, "and you need to get your sleep. If there are other people over there, you won't get your rest." 84

Good Samaritan had recently opened a new four-story building, leaving the original two-story building empty. Sisters Michael Ann and John Wright placed mattresses on the floors of the old wing and created a male and a female floor to house demonstrators, which participants referred to as "Ecumenical Hall." 85 Parishioners also housed visitors in their homes. Volunteers prepared food for the guests in the kitchen at Good Samaritan and St. Elizabeth's. Virginia Leary, head of the International Catholic Auxiliaries, along with some members of the organization, came to assist with food preparation. They slept on the floor of

\footnotetext{
81 Margery Frisbie, An Alley in Chicago.

82 Geck Interview.

83 Eileen Egan, "Turning Point in Selma," Peace Spring 1965,

84 Geck Interview.

85 Eileen Egan, “Turning Point in Selma," Peace Spring 1965,
} 
the parish center for girls. ${ }^{86}$

For those arriving in groups, the experience was somewhat organized. Many delegations like the New York and Chicago ClCs, arranged transportation for their groups. Others, like the Washington, D.C. and Kansas City delegations, traveled with ecumenical groups. The interfaith St. Louis delegation consisted of seven laymen, one laywoman, six nuns and twenty priests. The St. Louis Conference on Religion \& Race and the Archdiocesan Human Rights Commission jointly sponsored the group. St. Louis businessman Charles Vatterot chartered two planes. The flights were scheduled to leave Wednesday afternoon, but after discussing the plans with organizers in Selma, the departure time was changed to 6 a.m. so that the delegation might arrive in time for the afternoon marches. ${ }^{87}$ The delegation held a press conference at the airport and explained:

Without needlessly dramatizing the situation, it must be understood that an element of physical danger exists. It is our intention to join in the latemorning march on the Dallas County Courthouse, participate in any religious observance planned, cooperate with the Human Rights forces if anything else be asked of us, and then leave the town.

Most organized delegations had their members sign forms empowering the organizations to appoint attorneys and name family members in the event of arrest or injury. Some participants were given a "fact sheet" with important names, places and addresses in Selma. The sheets also included important safety tips. The Chicago CIC sheet warned participants to "remain within the 
Negro community. Do not wander downtown or visit white stores or restaurants. As a general rule do not travel on the streets alone."88 For northern whites, noted McDermott, these instructions were often quite ironic. "It was such a reverse from their experience in urban Chicago where even in those days a black neighborhood was considered hostile and strange, and here we had just the reverse."89 While safety was one primary concern, discipline was another. The delegation organizers repeatedly emphasized following the instructions of the SCLC. The St. Louis fact sheet cautioned:

If these precautions seem "overdone" we ask you to remember that a thoughtless action, an angry response can endanger the whole group. We are a part of a controlled mob-- discipline is all that keeps it under control and enables us to present a reasonable presentation of our views. ${ }^{90}$

Some organized delegations asked their members to sign a pledge promising to abide by the instructions of the group's leaders. Each group of marchers was asked to pick a contact person who would be responsible for bail and publicity in the event of arrest or violence. ${ }^{91}$ Participants were also reminded that two demonstrators had died in less than two weeks.

But despite the efforts of $\mathrm{NCClJ}$, the mission staff and movement organizers, lines of communication were often confused. When the Kansas City delegation arrived in Montgomery on Wednesday, they were greeted by two

87 "St. Louis Lead March in Selma," St. Louis Review, March 12, 1965.

88 "Fact Sheet: CIC Mission to Selma." CHS DCP.

89 McDermott Interview.

90 Community, S. L. R. (1965). "Supporting Justice." Tom? St. Louis, Unpublished.

91 Judith Mary, "On the Line in Selma with a Sisters Demonstrator," National Catholic Reporter, March 24, 1965. 
drivers from St. Elizabeth's who drove them in the mission's two Volkswagen buses. Sisters Judith Mary recalled that the first few hours in Selma were chaotic. Participants were unsure of who was in charge as a number of men, all of whom claimed to be working for King, issued contradictory instructions. ${ }^{92}$ Father Philip Hurley, S.J., a member of the NYCIC delegation, took the group directly to the barricade in front of Brown's Chapel. Sisters Judith Mary, S.L. of the Kansas City delegation recalled:

I found myself facing three rows of troopers' cars, six deep. Each car held four troopers. Directly in front of our singing, friendly line, which was sheltered from the rain by a makeshift plastic tent, [was] Baker, the Director of Public Safety, [who] sat in his car. This was the enemy. . I looked long and hard at the troopers, convinced they wouldn't hit a Sisters and waited for the world to move. ${ }^{93}$

For individuals who arrived on their own, the experience of Selma was even more disorganized.

Jerome Ernst was a twenty-one old journalist working for the Catholic weekly Extension Magazine. Hearing about Selma, he was determined to join the demonstrations. "I called my editor," said Ernst, "and said that either they were sending me to Selma to cover the story, or they could send my last paycheck to my house." He recounted that the first thing he saw upon exiting his plane was C.T. Vivian demonstrating what to do if attacked by a policeman: "Vivian had rolled up a newspaper and was beating someone over the head with it in order to demonstrate the proper technique for protecting yourself." Ernst

92 Ibid.

93 Ibid. 5. 
was taken to Brown's Chapel were he slept on the Rectory floor. Within hours, he too was on the lines in front of the Chapel. 94

For many this was their first experience dealing with segregation, nonviolence, and the chaos that accompanied a large movement. One unidentified Sisters claimed:

We did not come to Selma to sprinkle Holy Water on the movement. We found out immediately that we came to Selma to join something we should have joined years ago. I do not think that our greeting from SCLC would have been "thank you for coming to save us" but rather, "come, get to work; it's about time you joined us." 95

Some had no idea what they were getting into and thought that they would be free to do as they pleased. The participants were quickly given a basic lesson in nonviolent technique in orientation sessions run by SCLC and SNCC staff members. SCLC organizer James Orange introduced himself at one orientation session, "My name's James Orange and I work for the King Construction Company. We are in the process of rebuilding the South." James Bevel explained to the new arrivals that demonstrations would end in one of three ways: 1) the marchers would get to the Selma courthouse and hold a short service; 2) the marchers would be arrested; or 3) the marchers would be beaten. Bevel also gave a crash course in nonviolence. He explained:

The purpose of non-violence is to offer your body as a sacrifice and to absorb hate. There is a lot of hate in the white community downtown. I heard that the sale of firearms in Selma is up and so there is a lot of people hating there, and they've got to release that hate. And if they release it on

\footnotetext{
94 Jerome Ernst Interview by author.

95 Judith Mary, "On the Line in Selma with a Sisters Demonstrator," National Catholic Reporter, March 24, 1965.
} 
you, you must let them. If they release it on you, they'll get it out, and maybe it'll save someone else from getting beaten. There will be beatings before this march is over, and some of us may even be killed, but we've got to love, we've got to absorb the hate so that we dry it up-- so that there's finally none left. 96

Other leaders ominously advised, "While they are beating you, pray."97

Maintaining nonviolent and organizational discipline was a serious problem. Most delegations came and went, staying for only a few days. Many of the recent arrivals considered themselves leaders in their own right and were unaccustomed to taking orders and few were acquainted with mid level SCLC and SNCC staff members. Some newly arrived demonstrators expressed uncertainty at their own ability to remain nonviolent and one unidentified nun jokingly remarked, "I am not sure all those Irish are going to be good for the nonviolent movement."98 Making it clear that everyone had to follow orders was paramount. The Rev. Earl Neil, an Episcopal priest from Chicago, told one group, "You are simply to be of help to the leaders who asked us here ... No matter how big a Chief you were in your own teepee, when you came to the border of Alabama, you became an Indian."99

The issue of authority was all the more pressing for Catholics as they attempted to address issues of authority and conscience. In the weeks leading up to "Bloody Sunday," the Chicago CIC was embroiled in a struggle for control of the Council. The issue ostensibly dealt with a letter executive director John

\footnotetext{
96 Nicole D'Entremont, "To Selma and Back," Catholic Worker. April 1965

97 "Advice in Selma: If Beaten, Pray," Milwaukee Journal, March 15, 1965.

98 "Defiant Clergy Gather in Selma Despite Threats," New World. March 1965
} 
McDermott had written to Cardinal Meyer in January of 1964 regarding the desegregation of the Philip Neri Parish, a situation the Council had been involved with for some time. McDermott wanted the Cardinal to take a more active stance and order the parish to integrate and threatened protests against the archdiocese. Some council members, most notably Monsignor Daniel Cantwell, noted that the letter had not been approved by the board and felt McDermott had acted irresponsibly. But the issue was not about the specific solution to a problem. McDermott and Council Chaplain Cantwell clashed over the role clergy and laity were to play in the interracial justice movement.

Feeling that the board was leaning towards McDermott's position, Cantwell resolved to resign as the chaplain of the Council. $100 \mathrm{He}$ announced his intention at a board meeting on February 11. The minutes of the meeting reveal a wide variety of opinion among the members. McDermott praised Cantwell for his service and especially for his support of lay initiatives. In a letter circulated to the board, he wrote:

I do not think it would have been possible for us to operate as freely as we have without Monsignor's attitude of respect and restraint. But it is ironic that of all people, it is Msgr. Cantwell who must suffer because we have exercised the freedom he taught us about."101

But, McDermott charged that a chaplain could not be counted on to function in the best interests of the council, as he was beholden to the archbishop.

99 Selma, Civil Rights and the Church Militant (1965). Newsweek, 75-78.

100 Daniel Cantwell, "Remarks at CIC Board Meeting," February 11, 1965. DCP. CHS.

101 Chicago CIC, "Minutes of February 11, 1965 Board Meeting," DCP. CHS.. 
McDermott favored a more aggressive stance in dealing with the archdiocese. He told Cantwell privately, "You have played two roles, one for the hierarchy and another for the laymen in CIC."102 "The real issue," McDermott wrote, was:

Whether or not there is room in the life of the Church for adult men, whether or not there is genuine freedom for Catholic men to follow their conscience in implementing the social teachings of the Church in the temporal order, and as part of an organized and identifiably Catholic group."103

Cantwell felt that any aggressive moves towards the archbishop would destroy the Council's relationship with the hierarchy and derail any hopes for reform. At the meeting he stated:

The $\mathrm{CIC}$ cannot at the same time be inside and outside the functioning structure of the Church. The CIC cannot be part of the extended office of the Cardinal and at the same time be used or be associated with pressure tactics directed against him, or seemingly in his name directed against anyone else. I say the board must make a choice...The choice rather centers around what you think the actual role of a full time chaplain who represents the cardinal should be. This is only a small part of the central question: what kind of organizational relationship to the structure of the church do you want?"104

Cantwell feared that if threatened by the Council the Cardinal might create a new organization under his direct control to address the issue of racial justice and undercut the council's support. He rejected McDermott's conception of a 'lay church' at war with the 'clerical church,' and was unwilling to jettison the hierarchical nature of the Church itself.

102 John McDermott, J. "McDermott Letter to Cantwell." February 23, 1965. DCP. CHS.

103 John McDermott, "McDermott Letter to Cantwell, Edward M. Kravovec Jr., John J. Farrell, and Richard Walsh," March 4, 1965. DCP CHS.

104 Cantwell, "Remarks at CIC Board Meeting," 3. DCP. CHS 
Both sides of the debate struggled to chart the course of a lay-run, unofficial Catholic group seeking to involve itself more closely in the Negro revolution. One Board member said, "It will be a tragedy if CIC backs down from the strong leadership role it has played. $\mathrm{CIC}$ is the only thing that gives many Negro Catholics any hope in the Church."105 Edward Kravolec noted the "CIC has had to walk a tightrope; we are both in and out of the Church. This is our problem."106 A resolution that defined the CIC as "an organization of laymen and priests not associated with, or in any way dependent upon, top structure of the Church in order that in this way interracial justice and charity may best be promoted" was defeated. Another meeting was schedule for February 23 to resolve the issue. McDermott wrote to Cantwell and chided him for forcing the board to make a choice between the two of them.

The events in Selma, however, radically altered the context in which the Chicago debate was taking place. The experience of Christian witness momentarily removed both priest and layman from the nuances of church politics and served to mend the personal relationship of the two men. On March 10, McDermott wrote to Cantwell, "I don't want to end our friendship. Our problem is one of structure as well as personality, and if we can somehow work it out, I for one would be very happy."107

Similar debates regarding Catholic participation and the role of laity and

105 The Board member is identified only as Mr. Twine. $106 \mathrm{CIC}$ Minutes of February 11, 1965 Board Meeting. 
clergy occurred in Selma. Ouellet and Ahmann, the most prominent Catholic organizers, considered themselves facilitators, not leaders, of the movement in Selma. The New York CIC delegation had proposed forming a Catholic Coordinating Committee, but the Chicago delegation objected to the idea. McDermott recalled a meeting with Father Glenn Heally of the New York CIC:

We knew that he wanted to form some kind of an overarching Catholic committee to guide Catholic participation at Selma, under his leadership of course... And it isn't that we were against his idea, he didn't have an idea. If he had said why don't we propose to do ' $X$ ' as part of an overall scheme to help Dr. King then that would have been something to discuss but, no, he said that we should all be coordinated under one leadership structure. We said, "thank you, but no thank you."108

Catholics had responded to King's call and were there to help the movement with their presence as witnesses to the struggle being waged. The SCLC leadership in conjunction with SNCC and the DCVL decided strategy and tactics.

After the attack at the bridge, Monsignor George Higgins at NCWC contacted John Wright, public relations director at Good Samaritan. Higgins was familiar with Wright's work as a reporter with the Birmingham News and the Catholic Week. The NCWC and the Catholic news Service had no reporters in the immediate area to cover the developing story, and Wright's unique experience as a professional reporter attuned to Catholic issues made him the perfect choice. Wright interviewed King and asked him about the presence of Catholics. King responded:

107 John McDermott, "Note to Daniel Cantwell," March 10, 1965DCP CHS. Box 109, File "McDermott."

108 McDermott Interview. 
It has given a new, creative and encouraging dimension to our whole struggle. It has identified the Church with the struggle in a way that has not existed before and has made it clear that civil rights is, at the very bottom, a moral issue. We are so happy about the great response of the Catholic Church. ${ }^{109}$

Movement organizers immediately recognized the importance of the symbolic value the Sisters possessed. King noted that their presence had "a very special significance in arousing the national conscience to the plight of the Negro because the public knows a nun to be a woman of great sacrifice and dedication."110 Both F. D. Reese and Edwin Moss commented on the presence of nuns. "By them offering their presence and service," noted Reese, "they made it one of the outstanding events in the civil rights movement." Moss explained:

Their coming helps our cause and gives justification to demonstrations as the right way to achieve our goals. It certainly has given the Negroes of this community greater courage. It makes me feel that this is more than an Alabama movement. We feel sure their presence curbed further violence. The fact that they were permitted to associate makes us feel that we are right. ${ }^{111}$

Selma officials also commented on the role of Catholic nuns in the demonstrations. Wilson Baker recalled, "I think probably the nuns' presence did keep down violence." For the same reason, Mayor Smitherman was upset because the nuns acted "like a shield" for the demonstrators. ${ }^{112}$

109 John Wright, "Witnessing the courage, love of our black brothers and sisters." Bridge Summer $2000,2$.

110 Ibid.

111 lbid.

112 Ibid. 
While Catholic priests wearing Roman collars might be misidentified as

Protestant clergy, Sisters in their medieval habits were unmistakably Catholic.

Catholic women religious provided a powerful new symbol of Christian witness.

The presence of Sisters countered the criticism that the marchers were mostly young radicals.

March leaders also consciously positioned Sisters on the front line. "No matter where we would come," recalled NCCIJ staffer Sister Traxler, "anyone with a habit was asked to come up to the front of the line because they knew the troopers wouldn't storm it."113 Photographers were drawn to the images of nuns, the paramount symbol of the Catholic Church's social conservatism, on the front lines of potentially violent civil rights demonstrations. Sisters Judith Mary, S.L., remembered "cameramen jumped at the sight of nuns and spent the next hour till supper feeding their cameras with the black and white novelty."114 NCClJ director Matt Ahmann recalled:

We had nuns already there, but Andy [Young] . . . could see that there was a different response to nuns. People had become accustomed to some extent to collars, but a nun in a habit! I think that was good organizing-- it was a very fresh symbol. So we worked on that in the second round [of contacts] . . .Now many communities were already experimenting with modern dress. But SCLC said, "No, no, we want full habits!"115

The habits served to prevent violence and maximized the media profile of the nuns. The irony however is that a group of Protestants were more concerned

\footnotetext{
113 Traxler Interview.

114 Judith Mary, "On the Line in Selma with a Sisters Demonstrator." 5.

115 Ahmann Interview. The conversation was confirmed by Andrew Young Interview by author April 24, 1994
} 
about the symbolic importance of the habit than Sisters who in their reform efforts were attempting to move past the physical and social limitations of their traditional dress.

In addition to the many Protestant ministers and Catholic priests who spoke and offered prayers at the police line on Wednesday were six nuns from St. Louis. One Sisters, Mary Antona of the Sisters of Loretto, was African American. She had been asked earlier in Montgomery whether she feared for her life. She replied, "I'm willing to die. One of the charisms of women is to suffer. Another dimension is added to this dying daily when one is both a women and a religious." 116 As she approached the barricade she told Baker, "I am Sisters Mary Antona of the Sisters of Loreto. I am a Negro and proud of it. I vote and I want every American to have that right."117 When she entered Brown's Chapel after her stint on the line, Reverend Anderson declared, "this is the first time in my life I have ever seen a Negro nun." He asked Sisters Antona to stand up, at which point she explained, "I'm here as a Catholic, and a Negro, and a nun. And because I want to give witness." The crowd applauded wildly. ${ }^{118}$

Sisters themselves promoted their role in the movement. On Tuesday, March 11, two Sisters from St. Louis, Sr. Thomas Marguerite, C.S.J., and Sr. Ernst Marie C.S.J., spoke on the CBS radio show "At Your Service." The phone lines were so flooded the day of the show that the station scheduled a second

\footnotetext{
116 Margaret Traxler, "The New Nun-- Ministry of Presence." Community. 26:6.

117 Egan, "Turning Point in Selma."

118 "St. Louis Clergy Lead March in Selma," St. Louis Review, March 12, 1965.
} 
day of airtime for the Sisters. On the second day local calls were received at the rate of 100 per minute while over 6,000 busy signals were recorded. Over the two-day period the total number of calls reached $20,000.119$

The full-fledged participation of so many Catholics made it all the more difficult for the mission staff not to march. "I can state unquestionably that we priests felt very badly because we could not take part in the march," said Ouellet, but he never lost sight of his commitment to the mission and abided by the archbishop's order. While he was thankful and amazed at the sheer numbers of Catholics who came to Selma, their presence also disturbed him. He said:

And so as far as the Church was concerned, it wasn't until that time that Dr. King came, then everybody came. I as a priest felt angry about that. I was saying in 1963 our lives were really in danger. It was really bad business. Where were you? That was when we really needed you. There was a feeling that now that Dr. King was here, there were T.V. cameras. That was when Dr. King said [to me] "that is not the point. The point is that they are here." He had waited ten years; I had waited two. ${ }^{120}$

Ouellet's feeling that the outside demonstrators would be here momentarily and had no long-term commitment to the local community mirrored SNCC's criticism of SCLC policies.

On Thursday March 13, King went to Montgomery to testify before Judge Johnson's hearings. Justice Department attorney John Doar remained in Selma after meeting with Dr. King, and mediator Leroy Collins cancelled a Florida speaking engagement to return to the city. The Justice department asked Judge Johnson to forbid Governor Wallace and state law enforcement officers from

119 “The Listeners Called in-- 20,000 Times” 1965. The Catholic News, March 18, 1965. 
interfering with peaceful demonstrator and cited the February 10,18 and March 7 assaults on demonstrators. The acts of the defendants, the complaint said, "have not been directed towards enforcing any valid law of the State of Alabama, but have been for the purpose of preventing and discouraging Negroes from exercising their full rights of citizenship."121

After Bloody Sunday, President Johnson gave no indication that he was preparing to take dramatic action regarding voting rights. On Tuesday, March 9, the President met with Speaker of the House John McCormack. Forty-three representatives and seven senators called for voting rights legislation on the house and senate floors earlier in the day. ${ }^{122}$ McCormack suggested that the President address a joint session of Congress. The session was eventually scheduled for Monday, March 15. Johnson was deeply moved by the crisis, especially the death of Reeb. However, he rejected deploying troops to Selma. 600 picketers protested the government's inaction across from the White House in Lafayette Park. ${ }^{123}$

On Thursday, March 11, Vice President Hubert Humphrey met with a delegation of clergy to discuss the crisis. Monsignor George Higgins of the NCWC was asked by the White House to attend the meeting. Higgins was

\footnotetext{
120 Ouellet interview.

121 Associated Press, "End Wallace Interference Justice Dept. Asks Court." Chicago Sun Times, March 11, 1965.

122 Garrow, Protest at Selma, 88.

$123 \mathrm{lbid}, 89$.
} 
concerned with how hard-line some in the movement were becoming. In a letter to Father John Cronin, he wrote:

I must say that I am a little concerned about the eagerness of the clergymen, nuns, and seminarians to take part in the demonstrations in front of the White House, which are calculated to leave the impression that Johnson is a segregationist. One of the pickets who took part in Saturday's demonstration was actually carrying a sign which compared Johnson to Governor Wallace. That's pretty dirty pool. ${ }^{124}$

Higgins demanded a guarantee from his colleagues that the meeting would not be described as a protest meeting. On Friday morning the group met with the President. Some of the clergymen were extremely hostile. Paul Moore Jr., Episcopal Bishop of new York City, asked Johnson why he had taken so long to get a voting rights measure drafted and before Congress. Johnson explained:

Two reasons. First, it's got to pass. We can't risk defeat or dilution by filibuster on this one. This bill has got to go up there clean, simple and powerful. Second, we don't want this law declared unconstitutional. This can't be just a two-line bill, as someone suggested. The wherefores and therefores are insurance against that. ${ }^{125}$

Higgins, by contrast, felt that the President displayed an understanding "of the complexities of the Selma problem"126

Saturday afternoon the President met with Governor Wallace for over three hours, and Johnson "quietly read Wallace the riot act."127 Following the meeting Johnson declared:

\footnotetext{
124 George Higgins, "Higgins Letter to Daniel Cantwell" March 15, 1965. CHS. DCP.

125 Richard Stolley, "Inside the White House: Pressures Build Up to the Momentous Speech," LIFE, March 26, 1965. 34-7.

126 Ibid. Interview with George Higgins by author.

127 Garrow, Protest at Selma, 100-1.
} 
It is wrong to do violence to peaceful citizens in the streets of their town. It is wrong to deny American citizens the right to vote. It is wrong to deny any person full equality because of the color of his skin. ${ }^{128}$

Johnson explained that he had instructed Wallace to declare his support for universal suffrage, to assure the right of peaceful assembly and to hold bi-racial meetings addressing the concerns of the demonstrators. ${ }^{129}$ Johnson then met with a joint Congressional delegation and explained, "The attorney general can draft, and Congress can pass a law, but only the President can use his office as a great moral instrument."130

In Selma, demonstrations continued at the barricades. Just after 9:00 p.m. Thursday evening, March 11, word reached the city that Reverend Reeb had died. Wilson Baker announced the news to the protesters. Demonstrators now manned the front lines hoping to march to the courthouse to hold a memorial vigil for the latest movement martyr.

128 Richard Stolley, "Inside the White House: Pressures Build Up to the Momentous Speech," LIFE, March 26, 1965. 34-7.

129 Johnson quoted in Ibid, 101. 
130 Richard Stolley, "Inside the White House: Pressures Build Up to the Momentous Speech," LIFE, March 26, 1965. 34-7. 


\section{Chapter 10 : "We Shall Overcome."}

Their cause must be our cause because it is not just Negroes, but really it is all of us, who must overcome the crippling legacy of bigotry and injustice. And we shall overcome.

Lyndon Johnson

Archbishop Toolen was convinced demonstrations should be halted. He was in close contact with numerous state officials who convinced him that King and other key organizers were being influenced by Communists. In addition he spoke on at least three occasions with Judge Frank Johnson in Mobile about possible solutions to the crisis. ${ }^{1}$ However he opted not to speak publicly about either the planned march or the large Catholic presence. The death of Reeb however forced the archbishop to issue a statement. That afternoon Toolen expressed regret and sorrow over the minister's death. "We tender our sincere sympathies and prayers to his family and to his congregation at their terrible loss," he said. However, the archbishop stopped well short of endorsing the demonstrations. He declared, "Nor is it enough to condemn those, who acting on animosity born of prejudice against their fellowman, have committed this crime." Toolen pointed out that Reeb had sacrificed himself for the cause of love and justice. Reeb's death demanded "the stilling of hatred and the end of the fires of prejudice so that justice may begin to work through love, understanding, respect, and harmony among our citizens." 2 The archbishop echoed this theme in a pastoral letter that he ordered read at all Masses on Sunday March 14. Toolen

\footnotetext{
1 Toolen Letter to Shehan, April 22, 1965. ADMA Box 1965, File S.
} 
stated:

We cannot remain silent in the face of growing racial tension and violence in the Selma area of our diocese. Justice, human decency and Christian brotherhood demand recognition of the real needs of the Negro people and every legitimate effort in their struggle to exercise fully all their constitutional rights has our complete support. We condemn without reservation the exercise of police power vested in the hands of our public officials as beyond the requirements of present difficulties and unable to affect their solution. At the time we cannot condone a complete disregard on the part of the citizens for statutes legally enacted in the interests of the common good and public safety.

But Toolen noted, "Lasting results cannot be achieved in an atmosphere charged with hostility and mutual recrimination." Such an environment would lead only to more violence, and all parties, the archbishop felt, should do all in their power to prevent bloodshed. ${ }^{3}$

When the assault on the bridge occurred, Father John Crowley, S.S.E. was traveling on a fundraising mission. The hospital was facing a $\$ 50,000$ deficit. On Thursday he was in New York to meet with the Archbishop of New York, Francis Cardinal Spellman. The two men discussed the hospital's financial situation as well as the political situation in Selma. Spellman donated $\$ 5,000$ and asked Crowley to read a letter he was having read at all parishes the following Sunday. Later that evening Crowley learned that Reeb had died. He phoned Spellman to request that the Cardinal donate the money in memory of the slain minister. Spellman agreed and gave him a check for $\$ 10,000$ in memory of Reeb. On Friday Spellman declared:

2 Frank Wade, "Alabama Murder of Reeb National Cancer," Catholic Week. March 12, 1965).

3 Thomas Toolen, "Archbishop's Statement on Racial Tension," Catholic Week, March 12, 1965. 
The frightening disturbances in Selma, Alabama culminating in the martyrdom of the Reverend James Reeb are a tragedy for America and must awaken the consciences of all who are fair-minded and against the evil of violating the rights of men. Racial and civil injustices are a cancer attacking the very life of our nation and society. Their eradication is the urgent concern of all Americans, and we cannot disassociate ourselves from this great challenge.

Spellman asked that Catholics pray for racial and civil peace at all masses on Sunday March 14, and that people "be encouraged to continue appropriate action in order that all our citizens may obtain their moral and civil rights."4 Rather than return to Selma as he had originally planned, Crowley traveled to Boston to visit with the Reeb family in order to explain to them the situation in Selma and the South and to offer his condolences. ${ }^{5}$

Other bishops issued statements after the assault on Reeb and most described the minister's death as martyrdom. Archbishop Ritter of St. Louis explained that his sympathy for the Reeb family was "offered in shame -- shame that other members of my own human family could be so filled with hate as to do this thing, and yet my sympathy is also offered with pride -- pride that another member of my own human family could be a man like the Rev. James Reeb." Ritter announced that he had asked Monsignor Lloyd Sullivan to attend the memorial service for Reeb on his behalf. Archbishop O'Boyle noted "All Americans must have felt a sense of shame and outrage at the callous denial of justice in Alabama this week. Not only were Negroes refused their constitutional right to vote but when they attempted to exercise another constitutional right, that

\footnotetext{
4 Spellman quotation.
} 
of peaceful petition, they were met with clubs, whips, and tear gas." Bishop Navaugh of Patterson, Bishop Ernest Primeau of Manchester, Bishop Coleman F. Carroll of Miami had prayers said March 14, 1965, for "all those involved in the tragic racial struggle in Selma."6 Bishop Floyd Begin of Oakland said, "To treat human beings with such a shabby contempt is an insult to the personal dignity of man."7 One of the most outspoken bishops was Bishop Lucey of San Antonio who declared:

After all this, some Catholics will probably still maintain that civil law is sacred; priests should be the first to obey; they should stay home and be quiet. If some law is unwise, let the laity clean it up. Priests should be docile, meek and humble of heart. Demonstrations are undignified. These Catholics should recall that our Lord demonstrated vigorously one day even in the temple where he found men selling oxen, sheep and doves. He also saw moneychangers at their tables. And making a whip of cords, he drove them all out of the temple. Then he poured out the money of the changers and overturned their tables. And He said: "My house is a house of prayer but you have made it a den of thieves."8

Lucey concluded, "If it is wrong to defy an unjust law, the leaders of the America Revolution were traitors to the crown, and Benedict Arnold was a saint."9

The national outcry over Reeb's death further strengthened the resolve of the recently arrived participants and attracted more to Selma. The Chicago CIC delegation arrived Friday afternoon. During this time, two priests went over to discuss the situation with Archbishop Toolen. The chancellor, Monsignor Oscar

5 Crowley Interview.

6 "Religious Leaders Around Country Denounce Racial Injustice," New Orleans Clarion Herald March 18, 1965.

7 Ibid.

8 Lucey, "Murder in Alabama," Alamo Messenger March 19, 1965

9 lbid. 
Lipscombe, informed the group they did not have an appointment and that the archbishop would not see them. ${ }^{10}$ Sisters Traxler recalled them wanting to ask the archbishop, "Do you know what is happening? Why don't you come over and look before you blot it all out."11 While they did not feel that his permission was necessary to be there, they realized that if he were to change his mind, a major obstacle to the participation of many Catholics would be overcome.

The large number of demonstrators who traveled to Selma following Reeb's death soon overwhelmed both SCLC and SNCC organizers. Ahmann sent a telegram to SCLC headquarters in Atlanta. It read:

Late Wednesday night Ralph Abernathy asked me to try and get additional Roman Catholic priests and nuns into Selma. They have been arriving since yesterday afternoon. I estimate that by this afternoon there will be priests and nuns from over 40 Catholic dioceses. I have been unable to reach any SCLC or SNCC leadership by telephone since yesterday. Shall I quit organizing? What are plans? Please advise ${ }^{12}$

There were simply too many people and not enough for them to do. In addition tensions between SCLC and SNCC were rising. SCLC wanted to limit violence, while SNCC wanted to force a confrontation with the police. ${ }^{13}$ On Friday a few SNCC staffers tried to convince some nuns to provoke an incident at the barricade. Father Ouellet was called and he sternly lectured both students and Sisters. "We are not looking for heroines and heroes," he said. "We only want

\footnotetext{
10 Oscar Lipscombe Interview by author February 3, 1997. Note: Lipscombe is presently the archbishop of Mobile.

11 Traxler interview.

12 Matthew Ahmann, "Ahmann Telegram to King," March 12, 1965, NCCIJ Papers. MUA.

${ }^{13}$ Frank Aukofer, City with a Chance: A Case History of the Civil Rights Movement, (Bruce

Publishing: Milwaukee, 1968), 87
} 
those who are going to help the cause of interracial justice. Anyone else may leave now."

On Saturday, March 13, Monsignor Cantwell, Father John Cavanaugh, C.S.C., former president of the University of Notre Dame, and Sisters Mary Peter of NCCIJ were elected head of a Catholic delegation scheduled to man the barricades. Cavanaugh, when stopped by Baker, explained, "We may talk cross while excited. But we ask you to pray for us, that you may see our cause. We don't look for violence. We believe in justice for all. We ask the blessings of God, of the Father, the Son and the Holy Ghost on all of you." Baker retorted, "This is no argument of faith. We all follow God. I worship the same God you worship. But you are not going to proceed."

The group remained at the barricades for two hours before being relieved for dinner to Brown's Chapel. As the group departed, Cavanaugh and Baker shook hands. Baker laughed, telling newsman he, a Baptist, had gone to Notre Dame last October to address the Honor Society of the Law School. ${ }^{14}$ After dinner the group, now headed by Cantwell returned to the police barricade. Late that evening some members of the group wanted to return to St. Elizabeth's, but it was dark and the streets were crowded with whites. In order to prevent another potential assault on an out-of-town minister, Baker announced over his bullhorn that he would provide transportation back to the mission. Cantwell

\footnotetext{
14 See also "Demonstrators Saturday Halted in Two Marches," Selma Times Journal,
} 
recalls the gesture as an example of "rationality in an irrational situation."15

As the organizers and the participants prepared to settle in for a longer engagement than any of them had planned, a daily routine emerged in the Catholic community. It began with a morning Mass at St. Elizabeth's. While priests had not asked Toolen's permission to be in Selma, they could not say Mass without first obtaining faculties from the local ordinary. Toolen issued a memo which stated that visiting priests would be allowed to say Mass for two mornings after arriving in the diocese after which they must present credentials to chancery in order to obtain permission. ${ }^{16}$ The Mission also faced the problem of providing for the spiritual needs of visiting Catholics. The staff quickly realized that the attendance at the Sunday Mass would be overwhelming, and the mission's supply of communion hosts would not suffice. Sisters Mary Paul Geck remembered that the Sisters called churches in Birmingham and Montgomery to solicit extra hosts. Some priests refused outright to supply the mission. Eventually, a group of Carmelite Sisters in Montgomery gave the mission a number of large hosts, which they broke into smaller pieces. ${ }^{17}$

During the services Ouellet stressed that everyone must maintain nonviolent discipline. He also commended the hospitality the parishioners were providing for the many Catholic visitors. The parish bulletin noted:

\footnotetext{
15 Daniel Cantwell, "To Witness," Friendship House Newsletter CUAA George Higgins papers Box 129, File 131.

16 Thomas J. Toolen, "Faculties for Visiting Priests Memorandum," undated, ADMA. Box: 1965, File: "Selma Demonstrations."

17 Geck Interview
} 
The generosity of all the parishioners has been very evident. We ask you to continue to receive our visitors well. I am sure that our visiting priests and Sisters would be very pleased to meet our Catholics, so if you should see them, introduce yourself and assure them of their welcome here. ${ }^{18}$

In his sermon, Ouellet asked that they go back and tell people what they had seen. ${ }^{19}$

Many of the visitors were not content to simply stand at the barricades. Small groups attempted to integrate the white Episcopal and Baptist churches in the city, but were not allowed to enter. The Rev. Frank T. Matthews Jr., rector of St. Paul's Episcopal Church, met privately with a delegation of Northern Episcopal clergy. He stated that he saw "nothing wrong with Negroes and whites worshipping separately." But within days, pressure was brought to bear on the minister. By the end of the week Matthews had left town "on the insistence of my doctor and the demand of the vestry."20 Despite Ouellet's pleas for restraint, a small group of visiting Catholics from San Francisco and two parishioners tried to integrate the Mass at Assumption. "It was not a demonstration," noted one participant. There was no violence, although "there were some catcalls [and] priests returning from the Communion Rail were insulted by some parishioners." The group asked the pastor of Assumption, Father Charles F. Aucoin, whether Negroes could join his parish. "Well, I don't know," Father Aucoin replied

\footnotetext{
18 Maurice Ouellet, "St. Elizabeth's Mission Parish Bulletin," Sunday March 14, 1965. DCP. CHS. Box: 32 File: "Race Relations January - March 1965."

19 Geck Interview.

${ }^{20}$ Bass, Blessed are the Peacemakers, 169.
} 
hesitantly. "That is a legal question. Call in the canon lawyers."21

Another group of priests decided to pray the divine office on the street at

the barricade. Monsignor Cantwell later described the experience:

On one side of us was the barricade, the expression of human injustice and oppression. Surrounding us were the beleaguered people, in what was probably the same situation in which the psalms were first prayed. We prayed together and publicly of the law of God to which all human law must be subject. In this situation Psalm 118 took new life:22

Cantwell stressed the importance of maintaining nonviolent discipline. He said, "The eyes of the world are upon us. We must be sensitive to that which is undignified and undisciplined," he said. "This is primarily a moral and spiritual problem, and we must move as the whole Church."23

Around the nation demonstrations and memorials for Reverend Reeb were organized. The Protestant Council of the City of NY, CICNY-- Bronx chapter, American Jewish Congress, Fordham University students and faculty, sponsored a march in New York. Of the 15,000 marchers, 500 were nuns and over 50 were brothers and priests. ${ }^{24}$ The demonstrators marched for two and a half miles in Harlem. The Sisters were Maryknoll Sisters, Sisters of Charity of Mt.

\footnotetext{
21 Daniel Cantwell, "To Witness." Speech given at the Friendship House in Chicago. George Higgins Papers CUA. Box: 129.

22 Ibid, 2. Psalm 118: "My soul pines for your salvation. I hope in your word. How I love your law, Oh Lord, Your law, Oh Lord, is my meditation all the day. Your commandment made me wiser than my enemies, which it is ever with me. I have more understanding than all of my teachers when your decrees are my meditation. I have more discernment than the elders because I observe your precepts. How sweet to my palate are your precepts, sweeter than honey to my mouth; through your precepts, I gain discernment, therefore I need your word. A lamp to my feet is your word, a light to my path. I resolve and swear to keep your just ordinances."

23 Edmund Rooney, "Quiet Chicago Priest A Leader in Selma," Chicago Daily News, March 15, 1965.
} 
St. Vincent, Franciscan handmaids of the Most Pure, Immaculate Heart of Mary, Sisters of Mercy, of St. Joseph, of Our Lady, of Christian Doctrine, and of

St. Dominic. The clergy were mostly priests from Harlem parishes. Mother Loreto Bernard of the Sisters of Charity explained

We hope to demonstrate for social and civic justice for American citizens on the basis of equality. That is why we are in the religious life-- to work for all men equally as God's children. Our community was founded by the Blessed Elizabeth Seton, who suffered discrimination herself and worked tirelessly for the underprivileged. Our institutions like the Foundling Hospital are dedicated to serving the underprivileged. Each of us has given her life for the underprivileged. It would be right that we should suffer and show our suffering when-- in Selma or anywhere-- any of God's children are oppressed."25

Cardinal Spellman read the statement he and Crowley had discussed earlier in the week. ${ }^{26}$ The largest rally took place in Boston where over 20,000 people attended the event on the Boston Common. The Boston CIC helped to organize the event, and Cardinal Richard Cushing led the group in prayer. ${ }^{27}$ Other marches were held in Chicago, Detroit, San Antonio, San Francisco, Seattle, and Washington D.C.

Back in Selma, on Sunday morning the chapel at St. Elizabeth's was full.

The theme of the Mass was the dignity of the human body. Ouellet also cautioned his parishioners and guests. He wrote:

This is a time of great excitement when people are tired and quick to make judgments. We should be very conscious of the fact that a movement, such as we are experiencing, needs leadership, and we should follow that

24 Bill Fanning, "New York in Selma," The Catholic News, March 18, 1965, 1.

25 Ibid.

$26 \mathrm{lbid}, 5$.

27 "Reverend Reeb Demonstrations Stir Moral Conscious of Hub," The Pilot March 20, 1965 
leadership if we expect to be successful. I would especially caution our young people to restrain themselves so as not to be carried away and possibly harm the cause for which we struggle. Let us all work together without bitterness. We shall overcome but only if we love one another and those who oppose us. ${ }^{28}$

The parish bulletin thanked those who were providing for the many visitors and requested additional volunteers to prepare lunches. After the morning service at St. Elizabeth's, the Sisters met in the basement of the parish for a quiet period of reflection.

While the movement leadership recognized the symbolic value of women religious, the Sisters were conscious of their participation in the movement in a different way. They were aware of their role as women religious in a movement dominated by men of all faiths. ${ }^{29}$ While logistical problems such as the amount of time a group could stay were discussed, the meeting primarily served as a forum to air concerns about the demonstration. It also allowed women to discuss the pain, oppression, and bitterness the Sisters faced while they manned the lines in front of Brown's Chapel. They discussed how they could relate the suffering and oppression they witnessed here to the suffering and oppression they experienced in the church. Sisters Mary Paul recalled speaking with some Sisters from Chicago:

We came down here to give witness and march with the people. We thought we were coming down here to do something that was so wonderful.

28 Maurice Ouellet, "St. Elizabeth's Mission Parish Bulletin," Sunday March 14, 1965. DCP. CHS. Box: 32 File: "Race Relations January - March 1965."

29 Traxler Interview 
But she said, sisters you sisters have been giving witness down here for thirty, almost forty, years. ${ }^{30}$

Participation in the meetings by women of the congregation served to strengthen the resolve of many of the Sisters and the faith of many of the laywomen.

Cantwell spoke at the Sunday evening mass meeting at Brown's Chapel. Many blacks in the movement were disturbed at the attention that Reeb's death had elicited from the media, the federal government, and among the visiting clergy. "It is a tragedy that it took the death of a white man to wake us up," he said. "It is a tragedy....when Negroes have been dying here for years and it didn't wake is us up."31 He also spoke about the effect that his participation had upon himself.

In great pretension, I came down here thinking I could do something for you. You have done something enormously important to me. I feel the very enormous weight of my own religious family for their insensitivity and blindness to the race problem for so long. We have lived for so long in the face of this monstrous evil." 32

The ecumenical nature of the mass meeting impressed everyone. That evening a Methodist minister led the assembly in an evangelical hymn. Eileen Egan, a reporter who had traveled to Selma with the New York delegation recalled:

I looked at the singers in the body of the plain square church and caught a fantastic, incredible picture- nuns in Benedictine habits of black, Maryknoll habits of gray, half a dozen other habits of brown and black-and-white collared priests in every nook and cranny singing, clapping, swaying to "That old time religion is good enough for me."33

\footnotetext{
30 Geck interview.

31 Edmund Rooney, "Quiet Chicago Priest A Leader in Selma," Chicago Daily News, March 15, 1965.

32 Ibid.

33 Egan, "Turning Point in Selma," 13.
} 
Catholic nuns were singing a Protestant evangelical hymn, while waiting to be told what to do by a black Baptist minister named Martin Luther. Harvard Divinity School Professor Harvey Cox noted, "The Catholic clergy at Selma had not rejected the idea of authority. They had chosen, in this instance, to submit to another authority, realizing it could mean danger or even death. They had chosen to obey Dr. King rather than Toolen."34

Newsweek noted that the participants had "worked out a kind of joint theology and spontaneous liturgy." 35 It described a service led by Episcopalians in a black Baptist church using borrowed Catholic vestments and communion bread as Jews sang Freedom songs. Presbyterian minister Donald Schilling noted that the demonstration was "the greatest ecumenical conference in history." We were together in spirit and purpose before we arrived," he said, "and it was much easier to get ahead with the business of making our witness known."36

On Monday morning March 15, Baker and his officers abandoned the barricades. The registrar's office was open, and, C. T. Vivian seized the opportunity quickly organizing a march to the courthouse. Shana Alexander, a writer for LIFE magazine, reported the sudden unexplained disappearance of Baker and his officers reminded everyone "how easy it had been a few days

\footnotetext{
34 See Harvey Cox, "Ferment in the Churches: The New Christian Soldiers," The Nation, October 11, 1965. 217.

35 "Selma, Civil Rights and the Church Militant," Newsweek, March 29, 1965, 75.

36 Ibid.
} 
earlier for hoodlums to club another cleric to death without interference on a lighted downtown street."37 One nun told a rabbi in front of her "You're my protector now."38 Sheriff Clark quickly moved in to prevent the march. He announced that individuals would be allowed to go to the courthouse, but no marches would be permitted. Cantwell was concerned that Baker's absence and Clarks' assumption of control would result in violence. ${ }^{39}$ Clark remained in charge for forty-five minutes before Baker reassumed control by moving his officers in between the marchers and Clark's men. During the ensuing standoff, SCLC officials and Baker negotiated for the right to hold a memorial service at the courthouse for Reeb. 40

A memorial service for Reeb was held at Brown's Chapel on Monday Afternoon. Monsignor James Shannon, Auxiliary Bishop-elect of St. Paul, participated in the memorial service and was the highest-ranking Catholic official to date to take part in the Selma crisis. Other notables included: Greek Orthodox Archbishop lakovos, Primate of the Greek Orthodox Church of North and South America, Episcopal Bishop John Hines, United Auto Workers President Walter Reuther and Massachusetts Representatives Silvio Conte and Edward Bolland. ${ }^{41}$ King delivered the eulogy. 42

\footnotetext{
37 Shana Alexander, "Three Strangers in Selma," LIFE, March 26, 1965. 38 Ibid.

39 Daniel Cantwell, "Cantwell Letter to George Higgins," March 17, 1965. DCP, CHS. Box 7, File: Higgins.

40 Fager, Selma: 1965, 124-125. Garrow, Protest at Selma, 104.

41 Garrow, Protest at Selma, 104.

42 Fager, Selma: 1965, 133.
} 
At the end of the service, Ralph Abernathy announced, "God done spoke from the Federal Court." Circuit Court Judge Daniel Thomas in Montgomery had ruled that the march to the Dallas County Courthouse could take place. Abernathy continued, "And we can line up and proceed right now." Abernathy specifically called three nuns to march right behind King. ${ }^{43}$

That afternoon the NCCIJ distributed a statement for all Catholic participants to sign. It testified to many of the changes fermenting in the Church long before Vatican II: an expanded definition of the Church, ecumenism, a commitment to social justice and the recognition of individual conscience. The statement read:

We, the undersigned, want to speak at the joy we feel at the witness of the Roman Catholic Church in Selma. In the face of gross injustice and brutality, amidst a growing national crisis, hundreds of priests, nuns, and laymen and women went to Selma and witnessed to the Gospel. As our bishops in the country have come to feel a greater responsibility to the entire Church, so have we all come to feel our responsibility in our own country. We have learned in Selma, through our own participation and through the witness of Protestants and Jews, that the Church can respond, that the responsibility to the Gospel in a crisis situation is not impeded by necessary and legitimate diocesan jurisdictions. ${ }^{44}$

This document was the only statement Catholic participants issued as a group.

Not all participants signed it, many had already left, but over 300 did.

At 9 p.m. on Monday night, President Johnson addressed the nation.

Johnson placed the week's events in Selma, Alabama, on a par with the country's epic battles:

43 Egan, "Turning Point in Selma," 13 One is identified as Sr. Rose Walter Maryknoll. The other two are only referred to by their order as a Benedictine, the other as a B.V.M. 
At times history and fate meet at a single time in a single place to shape a turning point in man's unending search for freedom. So it was at Lexington and Concord. So it was a century ago at Appomattox. So it was last week in Selma, Alabama. 45

Johnson declared the nation was faced with the challenge of securing equal

rights for all its citizens. He said:

But rarely in any time does an issue lay bare the secret heart of America itself. Rarely are we met with a challenge, not to our growth or abundance, our welfare or our security, but rather to the values and the purposes and the meaning of our beloved Nation. The issue of equal rights for American Negroes is such an issue. And should we defeat every enemy, should we double our wealth and conquer the stars, and still be unequal to this issue, then we will have failed as a people and as a nation. ${ }^{46}$

Johnson declared there is no Negro problem, no Southern problem, no Northern problem, only an American problem. Americans had fought and died for two centuries to make the promise of liberty a reality. And the solution to the problem was clear-all men and women must be accorded their basic human dignity.

Those words are a promise to every citizen that he shall share in the dignity of man. This dignity cannot be found in a man's possessions; it cannot be found in his power, or in his position. It really rests on his right to be treated as a man equal in opportunity to all others. It says that he shall share in freedom, he shall choose his leaders, educate his children, and provide for his family according to his ability and his merits as a human being ... To apply any other test--to deny a man his hopes because of his color or race, his religion or the place of his birth--is not only to do injustice, it is to deny America and to dishonor the dead who gave their lives for American freedom. 47

\footnotetext{
44 "The Starry Heavens -- the Moral Law" (1965). Newsweek, 19-22.

45 Ibid.

46 Ibid.

47 Ibid.
} 
A number of Senators from Mississippi and Virginia did not attend the joint session. 48 Heading off potential constitutional challenges to his proposed legislation, Johnson pointedly declared:

There is no constitutional issue here. The command of the Constitution is plain. There is no moral issue. It is wrong--deadly wrong--to deny any of your fellow Americans the right to vote in this country. There is no issue of States rights or national rights. There is only the struggle for human rights. I have not the slightest doubt what will be your answer. 49

The next line of the speech was as unexpected by those listening in Selma, Alabama as it was by those in the House of Representatives and across the nation. "Their cause must be our cause because it is not just Negroes, but really it is all of us, who must overcome the crippling legacy of bigotry and injustice," the President said. "And we shall overcome." He continued:

The real hero of this struggle is the American Negro. His actions and protests, his courage to risk safety and even to risk his life, have awakened the conscience of this Nation. His demonstrations have been designed to call attention to injustice, designed to provoke change, designed to stir reform. . . He has called upon us to make good the promise of America. And who among us can say that we would have made the same progress were it not for his persistent bravery, and his faith in American democracy. . .For at the real heart of battle for equality is a deep-seated belief in the democratic process. Equality depends not on the force of arms or tear gas but upon the force of moral right; not on recourse to violence but on respect for law and order.

He ended the speech recounting his own experiences as a young teacher in East Texas and the discrimination he witnessed there. He assured Americans of their constitutional right to vote and promised legislation to guarantee it.

In Selma, people gathered in chapels, churches and homes, huddled

48 Ibid. 
around televisions and radios, some listening outside of windows. John McDermott recounted his memories of that night:

I remember being in [St. Elizabeth's] when Lyndon Johnson gave his ... speech. There was an electric moment in the room because that is what we were down there saying, "We Shall Overcome" and here is the President of the United States getting on board. There was a feeling of tremendous triumph. ${ }^{50}$

The speech was a climactic moment in the civil rights struggle.

Judge Johnson concluded his hearings on Tuesday but withheld an immediate ruling, instead saying that would hand one down "as soon as possible." 51 While march organizers waited for Judge Johnson to rule on whether to allow the march to Montgomery, they struggled to control the increasing numbers of protestors who came to the city. Wilson Baker was convinced that since these new arrivals had missed "the big show" they were determined to march. 52 More marchers attempted to circumvent the police barricades. Sheriff Clark had remained behind the scenes for the most part due to Baker and Smitherman's plan to restrict protests to the area around Brown's Chapel. But Clark desperately wanted to get involved. He told one group of marchers, "You'll march over my dead body." Baker tried to explain his reasons for preventing marches to the courthouse. "It is unsafe because of the tension and resentment from long drawn out demonstrations here." Baker finally allowed the marchers to make statements, telling them, "This is your show. Go ahead

49 Ibid.

50 McDermott Interview.

${ }^{51}$ Rex Thomas, "Rights Leaders Await Decision," Selma Times-Journal, March 17, 1965, 1. 
and make your statements and return to your church. You claim to be men of God, and if you are, you will stop this foolishness."53

Tuesday afternoon Mounted police stormed a 600-person demonstration organized by SNCC at the State Capital building in Montgomery. ${ }^{44}$ The group marched from the Jackson Street Baptist Church to the capitol building. Law enforcement officials halted the marchers. Montgomery Sheriff Mac Butle, riding a horse and wearing a cowboy hat, ordered the group to disperse, shouting, "Get out of here!" 55 When the protesters refused to move, the Butler led the horsemen into the crowd swinging clubs, canes, and double lengths of rope. When one rider pinned a youth against a porch, a priest rushed up and pleaded, "Please let that boy go!" The possemen whacked the priest on the shoulder and snarled, "You bastard preacher!"56

State officials denied giving the order to advance and disperse the crowd and claimed it was a miscommunication. City prosecutor Dave Crossland said the sheriff had been asked only to disperse the small group and to help contain the others. Montgomery Assistant Police Chief D. H. Lackey claimed: "I don't feel like it was necessary. All our orders were to hold them and contain them. How they got the word to disperse this crowd, I don't know."57

\footnotetext{
52 Ibid.

53 "Hootenanny and Revival Flavor Local Siege," Selma Times-Journal, March 17, 1965, 1.

54 "Starry Heavens-the Moral Law," Newsweek march 17, 1965.

55 "Troopers Asked by City, State to Handle Mob," Selma Times Journal, March 17, 1965.

56 The Nation: Civil Rights" Time, March 26, 1965.

57 "Troopers Asked by City, State to Handle Mob," Selma Times Journal, March 17, 1965. Starry Heaven
} 
The images of the troopers clubbing unarmed demonstrators once again riveted media attention on Alabama. 58 The attack was the first real confrontation with law enforcement since Bloody Sunday. King announced that a major rally would be held on Wednesday to protest the assault. Numerous demonstrators traveled to Montgomery from Selma to man the protest lines. Father James Groppi, a diocesan priest from Milwaukee drove to the capitol along with Father Patrick Flood, Matthew Gottschalk and Father Austin Schlaefer. The four priests went to a house where SCLC and SNCC officials were conferring, and then they attended a mass meeting at Buelah Baptist Church. After the meeting, the priests participated in an all night prayer vigil. As had happened in Selma, various ministers offered prayers. Of the vigil, Groppi recalled, "That's something I have always wanted to do-- sit down in the heart of the segregationist South with a group of priests and ministers in an ecumenical protest." The priests marched the next day and then returned to Milwaukee. ${ }^{59}$

Tuesday afternoon Judge Johnson issued his ruling on whether SCLC would be allowed to march from Selma to Montgomery. In the decision, he wrote:

The plan as proposed reaches the outer limits of what is constitutionally allowed. However the wrongs and injustices inflicted upon these plaintiffs have clearly exceeded-- and continue to exceed-- the outer limits of what is constitutionally permissible. The extent of the right to assemble, demonstrate and march should be commensurate with the enormity of

58 Rex Thomas, “Nobody Admits Giving Orders for Attacks," Selma Times Journal, March 17, 1965.

${ }^{59}$ Aukofer, City with a Chance, 94 
wrongs that are being protected and petitioned against. In this case, the wrongs are enormous. ${ }^{60}$

Movement organizers were ecstatic. The week following the ruling was spent frantically planning the overwhelming task of organizing a fifty-mile march of thousands of demonstrators to Montgomery. Hosea Williams announced that the march would begin on Sunday, March 21, and conclude on March 25.

On Wednesday in Selma there were indications demonstrators were becoming restless. While groups were again permitted to make their way to the courthouse, for the first time a protest was held outside of the area around the courthouse and Brown's Chapel.61 Tom Connell, an editor for the Catholic Worker, and over 400 people picketed Mayor Smitherman's home that afternoon. As the mostly white picketers were loaded onto a bus to be transported to the jail they began to sing Freedom songs. Baker was incensed that the group had attempted to demonstrate outside of the designated area, ruefully observed, "What a point this movement has come to. At least before we had good singing."62 All were taken into protective custody and brought to the Dallas County Courthouse. Later they were moved to the Negro community center. A few hours later they were released on their own recognizance, but opted to stay

60 Ruling cited in "The Nation: Civil Rights" Time, March 26, 1965. Garrow, Protest at Selma, 111112.

61 Garrow, Protest at Selma, 110.

62 Fager, Selma:1965, 144 
overnight in the black community center where they were housed because "no one dared to leave the building after dark."63

On Wednesday morning, the Senate Judiciary Committee held hearings on the President's proposed voting legislation. That evening, Archbishop Toolen publicly responded to the demonstrations at a St. Patrick's Day banquet in Mobile. To date Toolen had not discussed his position on the presence of Catholics in the marches. As the archbishop left the event in Mobile he was asked by reporters what he thought of the situation in Selma. Despite having agreed not to speak publicly on the matter, he gave an extensive impromptu interview. ${ }^{64}$ Toolen called for the equal treatment of African Americans, and readily admitted the difficulties placed in the way of African Americans attempting to register. He added, "If I took one of these examinations, I would probably fail." But he was noticeably offended and upset by the presence of clergy and religious:

Certainly the nuns are out of place in these demonstrations; their place is at home doing God's work. I would say the same is true of the priests. As to whether they have permission to come in-- they have not asked for it. It is customary to ask permission in such cases. What do they know about conditions in the South? I am afraid that they are simply eager beavers who feel this is a holy cause. ${ }^{65}$

Toolen was completely opposed to any demonstrations because he thought they only incited violence. According to Toolen, King and SCLC were "trying to divide

63 "Focus: Local Eyewitness on March on Montgomery." San Francisco Monitor, March 25, 1965. 64 Lipscombe Interview. Lipscombe notes that while the interview was not planned, Toolen felt that the reporters covering the event had quoted him fairly. 
the people" through demonstrations. The archbishop was also upset that those working for the betterment of Negroes were not getting proper credit. Presumably he had himself in mind. Again he admitted that "some corrections in our attitude toward the Negro people were needed," but he pointed to the example of the African American community of Mobile which had not seen demonstrations. He closed his remarks by saying:

Let us be sensible. We know that all men, regardless of race and color, are made after the image of God. We know that all are redeemed in the blood of Jesus Christ. All citizens are entitled to equal rights under the constitution. But these problems must be solved in a lawful way...There are crazy people on both sides. As good citizens of Alabama, we should try to control them. 66

Reaction to Toolen's statement was swift.

The Alabama legislature passed a joint resolution praising Toolen for his wisdom and guidance. The resolution described the situation as "desperate" and the state as "overrun with outsiders" who threatened the "cherished social order" with violence. Despite the archbishop's objections, few heeded his request. Newsweek reported, "The spirit ---if not the letter--- of Catholic canon law had in fact been ignored by Catholic bishops who 'allowed' their priests and nuns to enter the Mobile-Birmingham diocese without first asking permission of the archbishop."

Rationale for disobeying the archbishop varied. One priest claimed that "conscience is the highest law" and another priest denied that Toolen had any March 19, 1965. 
jurisdiction over such a universal issue as human rights. He claimed:

I owe obedience to my Bishop and I don't see that in this situation I owe obedience to Archbishop Toolen. I think that what happened in Selma is a cause of concern to the universal Church, and it's not a local issue any more than the political situation is a local issue. Politically, we do not allow Governor Wallace to represent the US; by the same token I don't see that one Bishop can represent the Church in the US. 67

John Butler of NCClJ was more pragmatic when he observed that it was not grand theological principles that enabled Catholics to defy the archbishop, but the public support of the marchers. "A lot of priests came without permission from either end," Butler said. "If the public hadn't supported them we all would have been hung."

The group that had most carefully addressed this very issue was the Priests' Rights Committee. The committee had met in Chicago exactly one year earlier to discuss the issue of ecclesiastical authority and the participation of priests in demonstrations. The committee declared the Holy Spirit invested bishops with authority and stimulated the conscience of priests. In order to address the potential for conflict between bishops and priests, the committee argued, "The exercise of individual conscience must be responsive to episcopal authority." However, eleven of the twenty-four men who had attended the meeting marched in Selma in complete disregard of Archbishop Toolen's

66 Ibid.

67 Cantwell, "To Witness." 
stance. 68

For his refusal to meet with a Catholic delegation and his public stance against the demonstrations, Toolen was vilified by many participants. Sister Traxler's recollection of the archbishop was typical:

We knew that he didn't give permission and we didn't care. He was sitting in his overstuffed chair fretting, poor guy. But you see, there he is...he had all of the white structure which was helping him run his diocese financially and he didn't want to say anything or do anything which would somehow diminish the money. He was a racist, plain and simple. Racism ran through all of his books, all of his morals. But again he was the product of his times, ignorant and abrasive. 69

Toolen's motives for curtailing the demonstrations were reduced by marchers to purely financial concerns. Father Frank Slobig declared "the real tragedy is that the great number of priests and nuns in the Alabama diocese who want to be involved in order to identify themselves with their own people can't-because he refuses to allow them. I think it is a violation of their own right of conscience." And Father Don Brooks of Lawton Oklahoma said Toolen had missed the point, "The Selma situation has hurt the movement of Christ toward the redemption of all men." Toolen was publicly transformed from a defender of African Americans to their oppressor, from the "nigger" bishop of the 1930s to the

68 Msgr. Daniel Cantwell, Msgr. Joseph Connolly, Rev. John Cronin S.S., Monsignor George Gingras, Rev. William Hogan, Rev. James Sheehan, Rev. John Shocklee, Rev. Sherrill Smith, Rev. James Stewart, and Rev. Thomas Carroll all marched. 
racist bishop of the 1960s.

69 Traxler Interview. 


\section{Chapter 11 : "Pilgrimage."}

It was a pilgrimage of dedicated people with a common cause-- the cause of justice. It was a group of different races, colors, religions, ages. There were old and young, rich and poor, black and white from all portions of the countryyet we were all one in Christ the great peacemaker. It was the greatest thing I have ever experienced.

Monsignor Victor G. Moser

Judge Johnson's ruling secured the organizers right to march, but hundreds of questions remained as to how the march would be conducted, and details regarding security, transportation, housing, food, needed to be worked out. The three days following the court order were spent frantically coordinating the enormous undertaking. Not only did SCLC and SNCC staffers need to plan for the fifty-mile march to the Alabama capitol, they also had to address an important shift in the nature of the campaign itself. "Like electric charges," Time magazine noted, "the civil rights movement has crackled between two poles--demonstrations and legislation."1 This march, unlike the original attempt on Bloody Sunday, was not an attempt to force a confrontation with state authorities, but a symbolic attempt to dramatize the need for federal voting rights legislation. While march officials did have serious concerns about the possibility of violence, their task was to minimize those risks, not accentuate them. Wallace hoped to stay Judge Johnson's order, but his appeal was rejected. Meanwhile President Johnson pressured the governor to promise to protect the marchers. Wallace 
claimed Alabama could not afford to pay for such a large undertaking.

Unable to obtain Governor Wallace's word that the marchers would be protected, the President federalized 1,800 Alabama National Guardsmen on Saturday. ${ }^{2}$ Ramsey Clark was appointed to head the operation. Clark and Justice Department officials scouted the route along Highway $80 .^{3}$ The four-lane highway quickly narrowed to two lanes and wound through swampy terrain, which offered numerous opportunities for an ambush.

SCLC designated Hosea Williams as the official in charge of organizing the logistics of the march. ${ }^{4}$ Randolph Blackwell was in charge of procuring supplies. The biggest question Blackwell faced was, "Where do you get food for three thousand people without buying it?"5 An operation the magnitude of the Selma to Montgomery march should have taken a month to organize; SCLC had less than a week. Blackwell called representatives of the Packinghouse Workers Union and arranged for food to be donated and transported to Selma. ${ }^{6}$ Blackwell later recalled:

I felt that this was an historical moment. It was very personal with me. I didn't discuss it with anybody. Didn't check it out. I felt that this was the moment when it had to be. And that every force that could be rallied should be rallied at this point. I felt that we were strong enough in terms of our own integrity to deal with any criticism that we would run into for the lack of preparation. And strangely enough there was none. ${ }^{7}$

1 The Nation: Civil Rights" Time, March 26, 1965

2 Garrow, Protest at Selma, 114-5.

3 Ibid, 115.

4 Fager, Selma: 1965 ,

${ }^{5}$ Raines, My Soul is Rested, 448.

6 Ibid.

7 Ibid. 
Blackwell also solicited other donations. He arranged for surplus blankets from a hospital in Boston that had recently closed to be delivered in a day to Selma on a donated plane. ${ }^{8}$

Dr. Ellwyn Allan Smith, Presbyterian minister and professor at Pittsburgh Theological Seminary, headed the Food Committee. ${ }^{9}$ Smith and twelve volunteers prepared meals around the clock at the Green Street Baptist Church in Selma for an undetermined number of people. ${ }^{10}$ The menu was oatmeal or cold cereal for breakfast, peanut butter \& jelly sandwiches for lunch and baked beans and spaghetti for dinner. ${ }^{11}$ Volunteers brought the food to the marchers in galvanized metal garbage cans. David Duncan and Kenneth Murdock (of the Chicago-based, interfaith Urban Training Institute) coordinated medical services, housing, communication and transportation. ${ }^{12}$ Yellow Hertz rental trucks were procured to carry food, water, hay, camping equipment, an electric generator and toilet facilities to the campsites each night. ${ }^{13}$ Work crews pitched two $50 \times 80$ foot tents for sleeping, one for men and the other for women, and two 30x40 foot tents for a mess hall and housing supplies. ${ }^{14}$

\footnotetext{
${ }^{8}$ Raines, My Soul is Rested, 450.

9 Fager, Selma: 1965, 151.

10 Peter Praetz "Black Selma," YCS Bulletin, April 1965, 9.

11 Fager, Selma: 1965, 151

12 Ibid, 146

13 Rex Thomas, "Rights Leader Await Decision," Selma Times Journal, March 17, 1965.

14 "Thousands March: King Rights Legion Head for Capitol," Birmingham Post-Herald, March 22, 1965
} 
News that the march would be allowed to proceed inspired a legion of men and women to come to Selma for the first time and for others to return, so that they might participate in the historic march. The march was scheduled to take place over five days and four nights. After arriving in Montgomery, march organizers planned to hold a mass demonstration at the state Capitol, where they hoped to present a petition of grievances to the governor. ${ }^{15}$ Campsites were selected on private property along U.S. Highway 80 . Walkie-talkies and two-way radios would be used to keep the demonstrators in touch with their leaders and with food wagons and equipment trucks. Judge Johnson ruled that an unlimited number of marchers would be allowed to walk along the 30 miles of four-lane highway, but citing safety concerns, no more than 300 would be allowed on the 20-mile stretch of two-lane pavement. Thus, a shuttle system was planned. Anyone else wanting to march could do so, but they had to return to Selma by bus each evening. The next morning marchers were bussed out to the campsite to complete the next leg of the journey.

SNCC's Frank Sorracco was given the unenviable task of choosing 300 participants to march the entire 50 miles to Montgomery. Only thirty-six spots were reserved for outside participants. Of those thirty-six, Sorocco chose four Catholics: Father Sherrill Smith of San Antonio, Father Rene Gusnier, O.S.B., of St. Meinrad's Archabbey, Sisters Mary Leoline, B.V.M., principal of Christ the King School in Kansas City, and Sisters Mary Patrice, I.H.M. of San Mateo,

${ }^{15}$ Rex Thomas, “Rights Leader Await Decision," Selma Times Journal, March 17, 1965. 
California. ${ }^{16}$ When Sisters Mary Patrice was chosen to march, she was

stunned. She called her superior and said, "Pray for me, mother. I've just been chosen . . . to march all the way to Montgomery. Pray for me. All of you there pray for all of us. It's a long, long way to Montgomery and I'm such a long way from you."17 Sisters Mary Leoline, was a bit more confident in her witness and noted that her superior, Mother Mary Consolatrice, gave her permission. "Mother Consolatrice," she said, "is very, very interested in extending the apostolate and doing all that we can to become relevant."18

Father Gusnier and Sisters Mary Leoline traveled to Selma to participate in the march to Montgomery. They came with Father Victor Moser, the director of the Kansas City $\mathrm{ClC} .{ }^{19}$ Sisters Mary Patrice traveled with the small California delegation. ${ }^{20}$ None of them had been to Selma prior to the march to the Capitol. Father Smith had demonstrated in Selma after Bloody Sunday. ${ }^{21}$ When asked why he was in Selma marching, he replied:

From my youth, I was a typical Northerner. I brushed shoulders with Negroes daily, but I never really saw them. While I was in service, though, we came up through Georgia, and I saw for the first time the terrible gulf

\footnotetext{
16 Cf: Fager, Selma: 1965, 153 and Traxler Interview. See also W.C. Heinz and Bard Lindeman, "The Meaning of the Selma March: Great Day at Trickem Fork," LIFE Magazine, 90. John Wright, "Priest-Sisters Selma Marchers Protest the Inhumanity of the Past 100 Years," New Orleans Clarion Herald, April 1, 1965.

17 Alice Burke, "Unsung heroes Stay on the Job" St. Michael's Review, Spring, 1965, 14.

18 John Wright, "Priest-Sisters Selma Marchers Protest the Inhumanity of the Past 100 Years," New Orleans Clarion Herald, April 1, 1965.

19 The two flew in a small private plane March 20, 1965. A local black Kansas City politician piloted the plane. When the plane landed, the door fell off. They returned to Kansas City on a commercial flight. See Rene Gusnier Questionnaire.

20 California delegation: Riordan, Sisters Mary Patrice, I.H.M., etc .

21 Father Sherrill Smith traveled to Selma on Tuesday March 9, and was Archbishop Lucey's personal representative to the memorial service for Reverend Reeb.
} 
between the Negro and the white man. It was like another country. Of course as a priest, I represent the Church, and I've felt great anguish about the silence of the Church in the South. We've made enough high-sounding statements, and it seemed to me that the time had come when we should be eyeball to eyeball. As a man, I've felt this keenly. All I know is that I just had to put my feet on this highway, and I just had to walk.22

Numerous Catholics who had marched earlier now returned to Selma to take part in the historic march. Many dioceses and orders sent delegations for the first time. ${ }^{23}$

The first day of the march was the second Sunday of Lent. The theme for the Mass at St. Elizabeth's was "The Evil in Our World." Ouellet proclaimed,

Christ has complete power over the devil. Our means of protection against all evil is to be found in our response towards The Word of God. We are blessed if we hear it and keep to it. If we keep it, we are to proclaim it.24

Following Mass, Catholic participants gathered outside of Brown's Chapel. The march was scheduled to begin at 10:00 a.m., but due to delays did not commence until $12: 48$ p.m. The route took the roughly 3,200 marchers through the city, over the Edmund Pettus Bridge, and seven miles along Highway 80.25 The group was scheduled to camp in a field belonging to David Hall. Marchers completed the first leg of the march at around 8:00 p.m., and chartered busses took most marchers back to Selma for the night.

\footnotetext{
22 Smith quoted in W.C. Heinz and Bard Lindeman, "The Meaning of the Selma March: Great Day at Trickem Fork," LIFE Magazine, 92.

23 Groups included: The Archdiocesan Commission on Racial Justice of San Francisco, Boston $\mathrm{CIC}$, Catholic Council of Human Relations of Houston, Catholic Human Relations Council of Los Angeles, CIC of Northern Kentucky, Chicago CIC, Detroit CIC, Milwaukee CIC, NCCIJ, New York $\mathrm{CIC}$, Saginaw CIC, Washington D.C. CIC, Youngstown CIC, Mundelein College,

24 St. Elizabeth Parish Bulletin, March 22, 1965. CHS Cantwell papers Box 32 File Race Relations January - March 1965

25 Garrow, Protest at Selma, 115.
} 
As the protesters marched through town and along the highway, white bystanders jeered and heckled them. Onlookers focused particularly on priests and nuns. Some carried signs that read, "Rent Your Priest Suit Here," "Yankee Trash Go Home," and "Fake Clergy and Beatniks Go Home."26 One reporter wrote "What Sisters Patrice, from San Mateo, Cal., and Sisters Mary Leoline, from Kansas City, heard concerning their chastity out of the mouths of the white women of Alabama cannot be transmitted in public print." ${ }^{27}$ One marcher recounted seeing a young white mother in her early 30 s who repeatedly shouted, "You all got your birth-control pills?"28 One of the most photographed marchers was Jim Leatherer, a member of the Catholic Interracial Council of Saginaw, Michigan. Leatherer had only one leg, and marched on crutches. He bore the brunt of numerous rude comments. In a mock military cadence, onlookers chanted, "Left, left, left."29 Leatherer was not sure that he would be able to complete the trek and asked that Holy Communion be brought to him every morning of the march. ${ }^{30}$

Fears of Klan violence were well founded. On the first day of the march, a parishioner at Our Lady Queen of the Universe, a black parish in the "Dynamite Hill" section of Birmingham, found 40-50 sticks of dynamite on the front steps of

\footnotetext{
26 Fager, Selma: 1965, 159. Stanton, From Selma to Sorrow, 157

27 Heinz and Lindeman, "The Meaning of the Selma March," LIFE, 90. 28 Ibid.

29 Fager, Selma: 1965, 153. The Saginaw CIC delegation included: R. Kenney Leatherer, President Saginaw CIC, Jim Leatherer, Fr. Robert Davey, Dr. Donald Cady, Mrs. Frank Mannion, Mrs. Frank O'Malley, Mrs. Lope Ortega, Mr. Frank Walsh, Mr. Al Van der Bellen. From the Junion CIC; Patricia O'Malley, Timothy O'Malley, Frank O'Malley Jr., Chris Mannion, Patrick
} 
the church. The timer had been set for noon, but apparently the batteries failed to set off the blasting caps. Father Foster evacuated the building without injury and police later diffused the bomb. Other explosives were found at the home of civil rights attorney Arthur Shores, the Smith \& Gaston Funeral Home and the black Western High School. ${ }^{31}$ Federalized National Guardsmen, regular Army troops, state troopers and police guarded the marchers. Spotter planes and helicopters surveyed the march from the air for snipers, while demolition teams searched the roadside for bombs. In addition, a select group of clergymen served as a SCLC security detail and patrolled the campsites. ${ }^{32}$

The next day Highway 80 narrowed from four lanes to two, and Johnson's order required that the marchers be limited to 300 . The marchers were scheduled to camp on the property of Mrs. Rosie Steele, a seventy-eight-year-old widow. As the marchers ate breakfast and prepared for the day, the weather changed and it began to rain. Many marchers were suffering from serious sunburn from the previous day's march. Father Sherrill Smith welcomed the rain as it offered a break from the harsh sun. He explained to a reporter that he had gotten very little sleep the night before due to the cold. One reporter described Sisters Mary Leoline stepping "firmly through the puddles, her black habit muddy from the

Mannion, Stephen Smith, William Smith Jr., Rebecca Martinez.

30James Maloney, C.M.F., "Three Days in Selma," U.S. Catholic May 1965, 12.

31 "4 Dynamite Bombs Found Here: Quick Action Prevents Explosions," Birmingham News Herald, March 22, 1965

32 Sisters Mary Leoline, BV.M. Affidavit. April 22, 1965 MUA NCCIJ Papers File: Congressional Record 
knees down and her face covered with white lotion."33 The day was warm with temperatures in the 60s, but few had rain gear and a few marchers used empty corn flake boxes for hats. ${ }^{34}$ The marchers covered eleven miles that day.

Segregationist politicians attempted to undermine public support for the marchers with a virulent propaganda campaign. On the second day of the march Alabama Representative William Dickenson introduced allegations into the Congressional Record that marchers were guilty of numerous immoral acts. The charges ranged from public intoxication, interracial kissing and hand holding, to the more serious charges of interracial sex, statutory rape and orgies. ${ }^{35}$ The office of Congressman Dickenson distributed a pamphlet, entitled "The Kingdom of Satan Is at Hand," to bolster the charges. It stated, "Free love among this group is not only condoned, but is encouraged" and noted that persons were recruited to participate by being promised $\$ 10$ a day and "all the sex they wanted from opposite members of either group." These bacchanals and orgies were alleged to have occurred in one of the movement churches. The pamphlet quoted a Selma resident who charged, "A white civil rights workers was molested by so many blacks that she is now dead." She accused civil rights' activists of covering up the murder. The pamphlet demanded an accounting of church funds used to support "civil rights" and questioned the role of the churches in political activity. Voting rights, the pamphlet explained, were "not in the spiritual realm of

\footnotetext{
33 Roy Reed, "Alabama March at the Midpoint: Sore Feet and High Spirits in Evidence at Camp," New York Times, March 24, 1965

34 Reed, "Alabama March."
} 
Christ our Lord," and the sins committed in the name of religion in Selma were indicative of the spiritual death suffered by the demonstrators. In his remarks on the house floor, Dickenson especially singled out Catholic priests and nuns. Besides the charges that "degeneracy, drunkenness, and sex orgies were the order of the day," he declared that the "hard core" of the marchers were organized and funded by communists. ${ }^{36} \mathrm{He}$ submitted police reports and affidavits from eyewitnesses to substantiate his charges. He also claimed to have photographs. However, the affidavits and police reports refused to name the minors involved "for their own protection" and Dickenson never produced any photographs. ${ }^{37}$

The participants and several impartial observers effectively repudiated these charges. Wilson Baker denied the allegations, saying he "knew of no photos to support public charges of drunkenness and immorality by priests and nuns during the Selma voting rights demonstrations." Montgomery police chief, Marvin Stanley, also denied having any knowledge of any such acts. Selma Times-Journal editor Arthur Capel did witness numerous instances of "embraces and kissing between racially mixed couples," which he claimed was done "to provoke and inflame" police officers and onlookers. But Capel saw no evidence of gross sexual misconduct on the part of marchers, and he claimed to have kept a round-the-clock watch on the demonstrations. Commenting on Dickenson's

35 Congressional Record, March 30, 1965, p. 6113.

36 "Marchers Repudiate Immorality Charges" Pittsburgh Catholic, May 6, 1965, 2.

37 "Civil Rights: Kiss and Tell," Newsweek, May 10, 1965. 
charges, he said: "I feel like this is a defense mechanism encouraged by local people, who are very resentful of what they consider to be an invasion, and they have struck back with such force that it has gotten out of hand."38

An ad hoc committee of march participants was also created following the march to address the charges. The Clergy for Truth in Alabama solicited affidavits from clergymen, seminarians and nuns who marched or worked in support crews. ${ }^{39}$ The committee declared:

We carried out the positive convictions of our respective consciences. It was our intent to lend dignity and to exemplify our Christian concern for human rights. This we did! This we will continue to do as long as it is necessary. ${ }^{40}$

Monsignor Victor G. Moser, Chairman of the Council on Religion and Race and member of the Catholic Interracial Council of Kansas City, Missouri declared in his affidavit:

It was a pilgrimage of dedicated people with a common cause-- the cause of justice. It was a group of different races, colors, religions, ages. There were old and young, rich and poor, black and white from all portions of the

\footnotetext{
38 "Alabama Officials Debunk Charges," Pittsburgh Catholic, May 6, 1965

39 Clergy coordinated their response to Dickenson's charges through the ad hoc group called Clergy for Truth in Alabama. "From Friday April 19, through Wednesday, April 28th, clergy and laymen of all communions from all parts of the country participated in an effort to bring to the attention of Congress, the press, and the people of the nation the facts regarding the Selma March." In addition to affidavits, the participants testified on the house floor and individuals sent telegrams to their congressional representatives. The coordinators of the group were the Rev. Rodney Shaw, Parthenon Press, Father John Cronin and Fred Sontag (See John Morris Letter to Matthew Ahmann, and Dr. Fred Sontag, Rev. Cannon Sharp, Rev. Dom Orsini, Rev. Arthur Walmsley, Rev. Rodney Shaw, Rev. Morris Samuel, April 29, 1965 MUA NCCIJ Papers File: $\mathrm{NCClJ}$ Correspondence) Dickenson claimed that a Wartburg Theological Seminary student left the march in disgust over the immoral conduct he witnessed. Norman Tuesdell denied that was the reason he returned to lowa. See Norman Tuesdell Affidavit. April 22, 1965 MUA NCCIJ Papers File: Congressional Record.

40 Rodney Shaw, Director Clergy for Alabama Truth, "Statement on Morality in Selma Crisis, April 28, 1965. MUA. NCCIJ Papers, File: Congressional Record
} 
country- yet we were all one in Christ the great peacemaker. It was the greatest thing I have ever experienced. ${ }^{41}$

However, the most telling rebuttal of all to Dickenson's inflamed version of the events in Selma came in a speech by Bob Craig, managing editor of the Spartanburg Journal. Craig posed as a marcher, in order to investigate the allegations. "You can find more sex at an average businessmen's convention," Craig concluded. He surmised that the orgy stories were invented to "cover up the basic fact that people cannot vote in Selma."42 One unidentified SNCC official scoffed at the charges and exclaimed, "Baby, everyone was too tired from all that marching."43 The traditional tactics of red-baiting, anti-Catholic bias, and charges of vice were ineffective and overall public opinion remained firmly behind the marchers.

The third night's campsite was on land owned by A.G. Gaston, noted African American businessman from Birmingham and civil rights supporter. However, the field was completely soaked by the rain. Work crews pitched the tents on a slight rise overlooking the flooded pasture. ${ }^{44}$ The next day, the group marched sixteen miles to the outskirts of Montgomery, and their numbers swelled as the highway once again opened up to four lanes. The final night of the march was spent at the City of St. Jude, the largest Catholic educational and medical facility serving African Americans in the United States. The City of St. Jude's

\footnotetext{
41 Victor Moser, Affidavit. April 22, 1965 MUA NCCIJ Papers File: Congressional Record 42 Ibid, "Spartanburg Editor Reports on Selma Rights March," Charleston News and Courier, April 27, 1965

43 "Civil Rights: Kiss and Tell," Newsweek, May 10, 1965.
} 
was run by diocesan priests and staffed by the Sisters of Charity. Located on the west side of Montgomery along Route 80 , the complex included housing for the staff, an elementary school, high school, large playing fields and a hospital specializing in pediatric care. Like the St. Elizabeth's mission, the City of St. Jude depended upon donations from across the United States to fund its activities. Paul Mulaney, director of the City of St. Jude, explained at a press conference:

It is our hope that these outside demonstrators will bring back to their own communities in their hearts what they witnessed in Alabama in order that it will help them solve their own racial problems. The racial problem is not limited to Alabama. Unions, housing accommodations are problems in many cities of our country, North, East, South and West. Therefore Alabama hosts this demonstration in order to express the terrible need for a more close communication between the races. ${ }^{45}$

SCLC aides negotiated with Archbishop Toolen for permission to use the grounds. Despite his recent remarks condemning Catholic participation, Toolen approved the use of the complex. ${ }^{46}$ He had approved the use of the complex to help the city officials avoid putting them up on municipal property. The large eighteen-acre complex was located in the African American section of town and was enclosed by a fence, making it an ideal choice for march organizers who were primarily concerned with safety. Tents were pitched on the large playing fields.

\footnotetext{
44 "Marchers Camp After 11 Mile Stretch," Birmingham Post Herald, March 24, 1965.

45 "Father Mullaney States Policy Involved In Use of St. Jude's Property," Catholic Weekly, March 26, 1965.

46 Ibid. Cf. Fager, Selma: 1965, 159.
} 
By the time the marchers reached St. Jude's, the number of participants had swelled to 10,000 . It took on a holiday atmosphere, as people from across the nation came to Montgomery to be a part of the historic moment. Dick Gregory, Harry Bellefonte, Tony Bennett, Sammy Davis, Jr., Nipsey Russell, Shelly Winters, Joan Baez and Peter, Paul and Mary, provided entertainment for the crowds at St. Jude's. ${ }^{47}$ The movement's logistical support crumbled under the vast throngs and when supplies ran out, marchers and supporters were left to fend for themselves.

On Thursday morning, the number of participants had swelled to 25,000 . Many participants who had been forced to leave earlier returned to complete the march. Others, sensing that this was a momentous occasion, came for the first time. The group included numerous Catholics who would go on to lead the church in other direct action campaigns: the Berrigan brothers, future leaders of the Catholic left, Father Groppi, who would later lead integrated housing marches in his home town of Milwaukee, and Father Geno Baroni who would organize an ecumenical response to the riots that later devastated Washington, D.C.

As the marchers entered the city of Montgomery, many noticed that there was no American flag flying over the capitol building, only the Confederate battle flag. Reporter Chris Condon, who covered the march for the National Catholic Reporter and KSD-TV St. Louis, explained:

Of the memories that they carried home I think one of the most searing must have been the sight of that Confederate flag atop the capitol building

47 Fager, 159 
of what was decided a hundred years ago in blood, is and will remain a state of the Union. Doubtless many privately determined to do what they could to see the stars and stripes restored some day to its proper place. One had a strong feeling in that square in front of the building with its renegade flag and blocked off by a cordon of state employees, of being in a tiny enclave in an alien land. America seemed limited to that small area of the rally site surrounded by the federalized troops. ${ }^{48}$

"It was like going to another country to see the Confederate flag up there," commented Father James F. Rowane of St. Padua's, Bronx, New York 49 "What struck me," said Father Bernard P. Donachie of the St. Patrick's Cathedral in New York, "was the almost complete lack of the American flag except in the hands of the marchers." He was shocked at white bystanders who called the stars and stripes "a nigger flag."50

Martin Luther King now stood on the same steps of the Alabama Capitol where Jefferson Davis had taken his oath of office on the spot 104 years earlier. The spot had been commemorated with a bronze star, which Wallace ordered covered with a sheet of plywood. ${ }^{51}$ Governor Wallace had been sworn in as governor. King's speech was a tribute to the firm determination of the marchers in their cause. The outpouring of public support following Bloody Sunday, King declared, had been "a shinning moment in the conscience of man."52 "The confrontation of good and evil," in Selma, King said, "generated the massive

\footnotetext{
48 Chris Condon, "First Steps Toward Reform," Catholic News, April 7, 1965.

49 Marie Oresti, "Notes on Maureen Bush speech to Detroit CIC," March 28, 1965. MUA. NCCIJ Papers. CICs- Detroit CIC.

50 Paul Mulcahey, "N.Y. Priests Jeered in Alabama," Catholic News, March 28, 1965.

51 Fager, Selma: 1965, 161.

52 King quoted in Garrow, Bearing the Cross, 413.
} 
power to turn the whole nation in a new direction." 53 In the familiar rhythms and intonations of a black preacher, King spoke of the road ahead and the difficulties needing to be overcome, foretelling a "season of suffering." ${ }^{4} \mathrm{He}$ brought his sermon to a close quoting the "Battle Hymn of the Republic." Following the speech, a representative committee tried to present Wallace a petition, but they were rebuffed. ${ }^{5}$ Wallace remained in his office guarded by state troopers.

As soon as the march concluded, the thousands of marchers-- clergy, laypeople, reporters, locals and visitors alike—began to make their way back home. The large military escort guarding the marchers was relieved of its duty and returned home as well. Viola Gregg Liuzzo was a mother and housewife from Detroit who had felt compelled to come and help in Selma. She arrived on March 17 and volunteered in Brown's Chapel arranging housing for recently arrived participants. Because she had her own car, she drove protesters to and from the airport.

Viola Gregg was born in 1925 in California, Pennsylvania, a small mining town located on the West Virginia border. Her father lost a hand in a mining accident, and the family often was forced to move in search of work. The family lived in Tennessee and Georgia before moving to Michigan in 1940, looking for work in the booming defense industry. She attended school through the ninth

53 King quoted in Fager, Selma: 1965, 163.

54 King quoted in Garrow, Bearing the Cross, 413.

55 "March into Montgomery" Chicago Sun Times, March 26, 1965 
grade, but then dropped out. She married her boyfriend in Knoxville,

Tennessee in 1941, but had the marriage annulled the following day. ${ }^{56}$ In 1943 she married George Argyris, the manager of the cafeteria in which she worked, and the couple had two children. Seven years the couple divorced. In 1950 Viola met James Liuzzo, a union organizer for the Teamsters. A year later they married. Jim and Viola had three children. ${ }^{57}$

Despite her lack of formal education and the demands of being a mother, Viola was involved in social justice issues. She and a close friend, Sarah Evans, an African American women whom she had met in Detroit, were both involved with the Detroit NAACP and attended seminars and workshops. ${ }^{58}$ In 1961 she enrolled in a medical assistant training program and eventually took a job as an assistant. In 1963 she began taking classes at Wayne State University in the hope of completing her education. In 1964 Liuzzo objected to a school board ruling reducing the age at which a student could drop out for school from eighteen to sixteen. Having struggled with her own lack of education, she fervently believed that children should be required to finish high school. She pulled her children out of school and home schooled them for a month in protest and was arrested for violating state laws regarding mandatory attendance. She refused to pay the fine and pleaded her case in court. She was convicted of the

\footnotetext{
56 The boyfriend was William Philips.

57 Mary Stanton, From Selma to Sorrow: The Life and Death of Viola Liuzzo, (Georgia University Press, Athens, 1998), 82-91.

58 Stanton, From Selma to Sorrow, 91.
} 
offence.59 In September of 1964 Liuzzo was briefly hospitalized for exhaustion; the strain of raising five children, her social activism, working and going to school had finally taken its toll. However, she resumed her studies the following semester.60 There she was drawn even further into the cause of interracial justice. She also began to explore religion. Her mother was Catholic, and Viola briefly attended parochial school as a young child but had not practiced the faith since her childhood. When she married Jim Liuzzo, she had converted to Catholicism, but she was not a practicing Catholic. In 1965, Liuzzo began to attend the First Unitarian Universalist Church and also attended workshops at the home of the Wright State University chaplain, Episcopal priest Malcolm Boyd. Here students discussed theology, ethics, culture and politics. Boyd was a former Freedom Rider and espoused what he called "an ethics of action." He later described her as "a truly religious person, not explicitly religious, but religious in a profound sense." She did not describe herself as Catholic, or as the member of any other denomination. When asked about her faith, she answered, "that she had no formal religion but believed in basic good conduct which is the basis of all religions." 61

While Liuzzo was horrified by the news images of Bloody Sunday, she did not immediately travel to Selma. Several days later she attended a memorial

\footnotetext{
59 Ibid, 60-61.

$60 \mathrm{lbid}, 105$.

61 Boyd quoted in Stanton, From Selma to Sorrow, 54. As a result of her conviction, Liuzzo was required to meet regularly with a parole officer. Liuzzo quoted in Stanton, From Selma to Sorrow, 104.
} 
service for Reeb at First Unitarian Universalist.62 On March 16, Liuzzo and her eldest daughter participated in a sympathy march at the federal building in Detroit organized by Wayne State students. That evening, they met with other students at Rev. Boyd's house. By the end of the evening, inspired by her own penchant to right injustice, the work she was doing in school, and her new interest in religion, she could no longer put off the urge to go and help. Liuzzo decided to go. She called her husband from campus to tell him she was leaving for Selma. She left directly from Wayne State without stopping home. ${ }^{63}$

On Thursday afternoon, as the march was making its way to the Capitol, Liuzzo spoke to Father Timothy Deasy, a member of the St. Jude's staff. She told him that she had a premonition of evil. "Something is going to happen today. I feel it," she said, "Somebody is going to get killed. You know it might even be Governor Wallace himself--- he may be killed by his own because he has a lot of enemies down here. And they would lay the blame on the marchers." ${ }^{4}$ Liuzzo watched King speak and then began shuttling participants back and forth between Montgomery and Selma. Early Thursday evening, Liuzzo and a young nineteen-year-old African American SCLC volunteer, Leroy Morton, began the return trip to Montgomery to pick up another load of demonstrators. At around 7:30 p.m., four Klansmen driving along Highway 80 noticed the young white women with a teenage black man in a car with out-of-state license plates. The

62 Stanton, From Selma to Sorrow, 133-139.

$63 \mathrm{lbid}, 105$.

64 Fager Selma: 1965, 160. 
couple symbolized everything the Klansmen abhorred and pursued them.

Liuzzo attempted to outrun the men, but she was overtaken. As the Klansmen pulled alongside the car, two of the men fired their pistols and struck her both times. One of the bullets struck her in the head, killing her instantly. The car swerved off the road and into a fence. Morton survived and played dead when the Klansmen returned to check on their prey. Morton fled the scene and was picked up by a passing truck carrying demonstrators back to Selma. He was taken directly to Brown's Chapel. The four Klansmen, Eugene Thomas, William Eaton, Collie Leroy Wilken and Gary Rowe were from Bessemer, Alabama. ${ }^{65}$ Authorities quickly learned the identity of the assailants because Rowe was a paid F.B.I. informant.

SCLC staffer and Episcopalian minister, Meryl Rouse, called James Liuzzo in Detroit to inform him Viola had been killed. Mr. Liuzzo was devastated by the news. Rouse then contacted the Episcopal Bishop of Detroit, C. Kilmer Myers, and asked if he would visit with the Liuzzo family. When told that Bishop Myers had arrived, James Liuzzo declared, "I'm a Catholic. I want a priest."66 James Hoffa, president of the Teamsters Union, offered the use of the Teamster's plane to fly Viola's body back to Detroit. ${ }^{67}$ SCLC officials organized a memorial march to the courthouse in Selma. The funeral was held in Detroit. Father Albert

65 On the history of Garry Thomas Rowe's involvement with the Klan and as an informant for the FBI see Diane McWhorter, Carry Me Home, 572-3.

66 Mary Stanton, From Selma to Sorrow: The Life and Death of Viola Liuzzo, (Georgia University Press, Athens, 1998), 58.

67 Ibid, 100. 
Hutting offered a high requiem Mass for Liuzzo at the Immaculate Heart of Mary in Detroit on March 30. Following the service, she was buried in the Holy Sepulcher Cemetery. Numerous high profile officials attended the ceremony --James Hoffa, Walter Ruether, Lt. Governor William Milliken, Auxiliary Bishop John Donovan, Martin Luther King, John Lewis, James Farmer and Roy Wilkins. Many Catholics were upset that the funeral took place in the church becasue Liuzzo had been divorced and had remarried. Regarding those who called the diocese to lodge their objections, the Michigan Catholic reported, "There was belligerence and hatred in their voices they deeply resented the prayers on her behalf and the consolation offered to her family." However, chancellery officials discounted the motives of those who opposed the ceremony. ${ }^{68}$ Father James Shehan, director of the Detroit Human Relations' Committee, delivered the eulogy. He declared:

Many Detroiters have criticized Viola Liuzzo for leaving her children to make the trip. People travel all over the world for business and pleasure and nobody criticizes them. But Vi's death touched consciences. . Today America hurts. All of us have pride in what our country stands for and are in anguish over the death of Viola Liuzzo. . The great work was in Selma and that's where she belonged. Now that she is dead, all over the world people are picking up the torch that she dropped, people who feel guilty for their brothers. ${ }^{69}$

Other memorials were held throughout the country. ${ }^{70} \mathrm{Jim}$ Leatherer, the onelegged Selma marcher, spoke at one service. He said, "Mrs. Liuzzo did not die in vain because thousands of people who've been uncertain of their course on civil

68 Stanton, From Selma to Sorrow, 101

69 Shehan quoted in Stanton, From Selma to Sorrow, 101 
rights are realizing you have to get off the fence."71 Michigan Governor George Romney designated two days of mourning throughout the state.

Viola Liuzzo's death and her lifestyle became a battleground between civil rights activists and pro-segregationists. Time magazine referred to Liuzzo as "the much-married Mrs. Liuzzo" and LIFE magazine as "the plumpish perky blonde, belatedly a sophomore at Wayne State University, who liked a cause."72 F.B.I. officials were reluctant to admit that an informer was involved in the murder and began to leak information in an effort to besmirch Liuzzo's character. ${ }^{73}$ Rumors involving drug use, interracial sex, prior arrests, and her unfitness as a mother were circulated. Even James Liuzzo's union connections were attacked and he was portrayed as "strong-armed extortionist." However, the harshest and most often heard criticism centered on the fact that Liuzzo had "abandoned" her children. Imperial Wizard Robert Shelton declared, "If this woman was at home with her children where she belonged, she wouldn't have gotten in jeopardy."74

Numerous civil rights and women's organizations praised her participation. The National Council of Catholic Women addressed the criticism of Liuzzo's decision to leave her family. The NCCW declared:

Women everywhere are challenged to ease the burden of other families where love and security are struggling against insuperable obstacles. . .Women in their natural concern for the nature of children cannot be content

70 Stanton, From Selma to Sorrow, 176-177.

$71 \mathrm{lbid}, 177$.

72 lbid, 100.

73 "Groups Praise Action of Mrs. Liuzzo," New World, April 9, 1965, 20.

74 Detroit News, March 28, 1965. 
to secure for their own children those benefits without seeking to assure them for all. ${ }^{75}$

However, the competing images of Viola Liuzzo as a naïve, disenchanted Northern housewife, as a drug addicted, sexual deviant, or as a pious Catholic laywoman were gross caricatures. The nuances of her beliefs and motivations were overwhelmed by the need to justify competing causes. In 1965 the world seemed black and white, and both sides used her life and death to describe a person that did not exist. While one side elevated her to the status of Catholic interracial martyr, the other lowered her to that of deranged, family-abandoning, nigger-lover. In truth, she was neither. Viola Liuzzo did not act out of a deeply rooted Catholic piety; she was a woman who chose to do the right thing and participate in a cause that she thought was just. After interviewing family and friends, Jean Sharley recounted how Viola Liuzzo taught her children "to take their lumps, to live intensely, treat all people as equals, and to keep their promises."76 Rather than abandoning her family, she felt that her actions were invaluable examples for her children.

The atmosphere that had settled upon the marchers only the night before turned quickly to moral outrage and shock. Support poured in again from all fronts as President Johnson ordered the FBI to fully investigate the murder and asked the House Un-American Activities Committee to begin a probe into Klan

\footnotetext{
75 Singers of the statement included the National Council of Jewish Women, the National Council of Negro Women, the United Church of Women and the national board of the Young Christian Women's Association.

76 Stanton, From Selma to Sorrow, 59.
} 
activity. Liuzzo's death reinforced what most seasoned veterans of the movement already knew—one march does not make a movement or guarantee its success. The nearly 1,000 Catholic participants of the seventeen-day demonstrations had returned to their homes and their dioceses along with the thousands of other supporters.

SNCC and SCLC began the next step: the difficult and dangerous task of organizing Alabama with limited resources and without intense glare of national media attention. The financial cost of the demonstrations was the first problem. The NCCIJ spent $\$ 15,000$ on telegrams, phone calls and plane fares and found itself $\$ 31,000$ in debt. ${ }^{77}$ The National Federation of Catholic College Students (NFCCS) appealed to its membership to help pay the NCClJ's debt. 78

When the marchers and the television cameras left town, the priests, nuns and parishioners at St. Elizabeth's went back to the job of running the mission, the school and the hospital. Divine protection, Ouellet noted was "more necessary now than ever. We're almost certain to be the main targets for reprisal and hatred from some elements of the white community for what happened in Selma these past three weeks. There are always crackpots. Our lives are in danger and we know it." However, what truly concerned him was that the nation would believe that the battle for equal rights had been won in Selma. Ouellet warned:

\footnotetext{
77 "Editorials," Ave Maria, March 26, 1965.

78 "Collegians Asked to Aid Selma Fund," Chicago New World, March 26, 1965
} 
That war wasn't won here, anymore than it was won in Birmingham two years ago or any more than it was won by the Supreme Court School decision of 1954 or the Civil Rights law of 1964. All that was won in Selma was a small battle. The war-- the non-violent war fought with the weapon of love that has destroyed men like Rev. Jim Reeb-- will go on and on. And we in the society of St. Edmund will go on and on, playing our small part in it. 79

Father McNeice explained that moderates on both sides were quietly meeting, but that there was a great deal of mutual recrimination. Officials continued to investigate the charges that the Sisters of St. Joseph had allowed Jimmie Lee Jackson to die. 80

On May 25, Ouellet wrote a note to thank a woman in New Hampshire who had donated clothes to the mission. "Our city is very quiet in comparison to some months ago, and we have returned to a normal routine of things," he said. "However, there is a change that has taken place and even though it is not apparent to strangers, we who live here can see that change. It is for the good, and I am sure that it will bring about good things in the future." ${ }^{81}$ By April the media was no longer focused on events in Selma. SCLC was unsure of how to capitalize on the success of the campaign. Immediately following the Liuzzo murder, King proposed a boycott on all Alabama products. However the idea was rejected on the grounds that such an action would harm as many blacks as whites. ${ }^{82}$ SCLC opted to continue voter registration efforts and James Bevel and

\footnotetext{
79 Burke, “Unsung Heroes," 12.

80 "Selma Appraises it Future: Moderates Meet for Action", National Catholic Reporter, March 24, 1965

81 Maurice Ouellet letter to Mrs. A. LeClerc. May 25, 1965. ARC, Ouellet Papers Box 1, File 3.

82 Garrow, Bearing the Cross, 414.
} 
Hosea Williams proposed competing proposals. ${ }^{83}$ By May SNCC had begun a voter registration campaign in Lowndes County. The Liuzzo murder trial also began in Haynesville in May. Despite the testimony of F.B.I. informant Rowe, the jury deadlocked 10-2 in favor of conviction. In Selma, following the march to Montgomery the boycott collapsed and by early May negotiations between black officials and Smitherman had stalled. ${ }^{84}$ The Dallas County Voters League was embroiled in a scandal regarding the dispersal of funds donated during the campaign. Another organization, the Selma Emergency Relief Fund (SERF) was embroiled in a scandal regarding donated food and clothing. The director of the program, Ezra Greer, and his staff were accused of hoarding the supplies and pillaging the best for themselves. F.D. Reese was arrested on charges of embezzlement in July.

On June 1, 1965 in a letter to Thelton Henderson, the African American Justice Department official involved in the King rental car scandal, Ouellet described the past few months. "I returned to Selma just in time for the demonstrations," he wrote, "and somehow managed to find the strength to do all that had to be done during those days. After it was all over I experienced such a fatigue that I have never known on all my life. I had to take a little time off and get some rest." 85 Despite the lack of progress with the mayor, community

\footnotetext{
83 Fager, Selma: 1965, 167-169. Garrow, Bearing the Cross, 416. Bevel hoped to continue his Alabama Project while Williams proposed a new organization, the Summer Community Organization and Political Education (SCOPE).

84 Garrow, Protest at Selma, 127.

85 Maurice Ouellet Letter to Thelton Henderson, June 1, 1965. ARC. Ouellet Papers.
} 
leaders were preparing blacks for professional employment, noting that a number of people were studying for the Civil Service exams. In addition Ouellet and others had formed a corporation to start a supermarket. Ouellet served as vice-president of the Board of Directors. "They taught us nothing about supermarkets in the Seminary," he wrote to Henderson, "so I may need a good lawyer." As for his relationship with Toolen, Ouellet described it as severely strained. Ouellet explained:

My tenure at present is quite shaky, even though I stay out of any direct participation in any demonstrations. It seems that I am being held responsible for everything that occurred here in Selma and the Archbishop did not favor the demonstrations. Therefore a goat is going to have to be selected and it looks as if I am standing first in line. But then again things may work themselves out. I sincerely hope so since I would feel very bad about leaving now. I had even more difficulty restraining myself from taking a real active part than I did when you were here. I managed to do so and wonder if I shouldn't have gone ahead and done what I wanted to do since I am going to be tossed out anyway. ${ }^{86}$

Two weeks after the letter, the archbishop asserted his authority and demanded Ouellet leave the diocese. While the archbishop did not have the authority to remove Ouellet, it was within his authority to order the entire order out of the diocese. Toolen gave no reason for the order. It was the first contact Ouellet had had with Toolen since their meeting two years earlier. The news that Ouellet was being transferred was quietly published in the mission bulletin.

Many parishioners were extremely upset about the order and petitioned the archbishop, the Apostolic Delegate in Washington and the Vatican to have the order rescinded. Parishioner Kate Trainor headed the Concerned Members 
of the Parish Committee to coordinate the parish's efforts to restore Ouellet.

The group's letter to the Pope Paul VI explained:

We, the parishioners, knowing the Church's stand on civil rights, feel this as a personal insult. We are concerned that all of Fathers endeavors and those priests who preceded him in bringing Christ to the poor people of this area may be severely damaged because of Archbishop Toolen's decision. Therefore, we would appreciate action on your part that would help to change this action of the Archbishop. ${ }^{87}$

Robert Crear, President of the Holy Name Society, wrote to Toolen and informed him that the mission would not be participating in the annual Holy Name convention in Mobile. Mrs. Thomas L. Robertson, President of the Ladies Sodality, and the entire Executive Board of the Confraternity of Christian Doctrine wrote to the archbishop to protest the removal. The C.C.D. board members wrote:

The removal of Rev. Maurice Ouellet from our parish is a source of discouragement to the work of the board. It is our understanding that the C.C.D. teaches true doctrine and relates it to daily life. Father Ouellet lived this and was making doctrine relevant to our lives and to the conditions in which we live. We admire your courage when you insisted that Catholic schools in Alabama be integrated. We think that your removal of Father Ouellet is wrong and will diminish Catholic influence in the community. ${ }^{88}$

Individual parishioners wrote to plead with Toolen to reverse his decision. One woman begged, "Please don't do it." Mrs. Alice West, who housed many of the demonstrators in her home at the Washington Carver Homes, asked, "I as a

86 Ibid.

87 Concerned Members of the Parish Committee Letter to Pope Paul VI, June 26, 1965

88 CCD Executive Board Telegram to Thomas Toolen. June 26, 1965. The letter was signed by Mr. Charles Maxey, President, Mrs. Rose Maxey, Secretary, Mr. John Crear, Chairmen- Apostles of Good Will, Mr. William Good, Chairmen of Fishers, Mrs. Mary Taswell, Chairmen of Parent 
Catholic always thought the Catholic Church was color blind."89 In all, 853 letters were mailed to the archbishop.

The NCCIJ, the NCWC, various CICs and a number of bishops protested his removal. Matthew Ahmann wrote to Ouellet to thank him for the work he had done and praise his accomplishments. He wrote:

We understand that controversy was but a normal consequence of either the intransigence of white men or the struggle within the conscience of whites, who have been accustomed to traditions of a bygone era. Fortunately there are signs that the work done by you and others is imposing an order on those who would continue to enslave Negroes politically, economically, and socially. And many people are now moving to forge a new community where the dignity of all is recognized by opportunities being available to all. . . Surely, your witness and the aid you gave the wider Roman Catholic community by your Christian hospitality in the trying days of national demonstrations, will live on and inspire countless thousands to stand with courage for the great commandment of the New Testament, that by our love will all men know that we are Christ's disciples ${ }^{90}$

Ahmann also petitioned Church officials to pressure Toolen to change his mind. In a letter to The Apostolic Delegate Archbishop Egidio Vagnozzi, Ahmann praised Ouellet for his work and pointed out that the city's other Catholic church remained segregated. Ahmann called St. Elizabeth's "one of the few Catholic parishes in the deep South deeply identified with the aspirations of the Negro people."91 Ahmann also wrote to Archbishop Toolen. He praised the archbishop for his efforts; especially Toolen's order that summer to desegregate the

Educators, Mrs. Mary Good, Teacher, Miss Eradean Jackson, Teacher, Miss Geneva Pate, Teacher.

89 Kate Trainor Letter to Matt Ahmann, June 30, 1965. MUA. NCCIJ Papers. Ahmann Correspondence.

90 Matthew Ahmann Letter to Ouellet, June 25, 1965. MUA. MUA. NCCIJ Papers. Ahmann Correspondence. 
parochial schools in the fall of 1965.92 But all efforts to change Toolen's mind were unsuccessful.

Toolen personally answered few of his critics. Regarding the mission's refusal to attend the Holy Name Convention, Toolen wrote to Craig and chastised him for his failure to attend the convention. He explained, "I have ignored your petitions because they came from a crowd and I only deal with the people through the priests. It has been impossible to deal with any priest in Selma for a long time." Regarding the actions of Ouellet, Toolen declared,

When he stated that he had my permission to meet with these people from the outside, he lied, and knew he was lying. He had permission to meet with the nuns of Selma and only the ministers of Selma. Many of his statements are just as untrue as this one and have done more harm for the Church in Selma and Alabama than can be remedied in the next twenty-five years. ${ }^{93}$

He again reiterated his contention that he was not a segregationist and recounted the numerous works he had initiated on behalf of black Catholics in the diocese. "All down the line it was not so popular to be on the side of the Negro and I was working for them and continued through the years and will in spite of Father Ouellet and his partners," wrote Toolen. "I have no excuse to any for my attitude."94

\footnotetext{
91 Matthew Ahmann Letter to Edigio Vagnozzi, June 25, 1965. MUA. NCCIJ Papers. Ahmann Correspondence.

92 Matthew Ahmann Letter to Thomas Toolen, June 25, 1965. MUA. NCCIJ Papers. Ahmann Correspondence.

93 Thomas Toolen letter to Robert Craig, December 13, 1965. ADMA, Box: 1965, File: W. 94 Ibid.
} 
Francis Cardinal McIntyre, Archbishop of Los Angeles, was one of the few supporters of Toolen. Throughout his career, McIntyre had been opposed to anyone challenging the status quo. ${ }^{95}$ The two prelates were both perceived to be archconservative-although, unlike Toolen, McIntyre seemed to relish his image as a defender of the status quo. McIntyre wrote to give his support to Toolen. "I fear that the question of demonstrations will be an active and disturbing one for some time to us all, and I am confident that the actions of some of our clergy and nuns going to Selma was not helpful to either cause," the cardinal said. 'It is obvious that the promoters were anxious to use 'religion' in all its publicity."96 But Toolen also felt betrayed by what he viewed as the disobedience of the priests and nuns who had marched and was disturbed by the increasing public perception of him as a "racist bishop."

In late April, Toolen wrote to Cardinal Shehan of Baltimore. The two were both from Baltimore and had been friends for a number of years. Shehan had been a strong supporter of the demonstrations. At a press conference in Baltimore on March 26, the Cardinal praised the ecumenical spirit of the demonstrations and defended the right of priests to participate. A priest is a citizen, Shehan argued, and did not lose his rights when he took his vows. He explained that short of a ban on participation by one's superior, a priest was free

\footnotetext{
95 McIntyre was chancellor of the New York archdiocese and had opposed most of Father John LaFarge's work in the 1930s and 1940s. In addition to his aversion to radical social and political movement, McIntyre resisted implementing many of the Second Vatican Council's liturgical reforms. See Charles Morris, American Catholic, 260-261.

96 Francis McIntyre to Thomas Toolen, March 22, 1965.
} 
to participate in demonstrations. ${ }^{97}$ "They made a segregationist out of me," Toolen wrote to Shehan, "and I have never been a segregationist." He repeated the allegations of immorality, noting that the behavior of the mob was "beyond description," but specifically pointed only to the fact that priests and Sisters stayed out past 11:30 p.m. "swinging and dancing with the Negroes and shouting and clapping." ${ }^{88}$ He closed his letter to Shehan, "Your Eminence, we have been friends too long for anything or anyone to disturb that friendship."99

Toolen received as many letters in support of his position as opposed to it. While Toolen was adamant in decision, he felt both his supporters and critics misunderstood his position. In a reply to one letter, Toolen explained:

Where were all these people 35 or 40 years ago when we were trying to do for the Negro. They all want to get on the bandwagon now, but not 35 or 40 years ago when those who had the best interest of the Negro at heart, working and suffering for them ... I still say, a great injustice has been done by these 'do-gooders' who came to Alabama. Looking at the problem from a distance and living with it is two different propositions. ${ }^{100}$

Toolen was caught between two competing visions of the demonstrations and constrained by the socio-political realities of the South. On the one hand, he believed that the march organizers, King and other leaders, had communist connections. On the other hand, he knew that segregation was immoral and had quietly worked to better the material, spiritual and political status of blacks in the diocese. Toolen also held to many of the baser stereotypes about blacks. In a

97 Shehan Press Conference March 26, 1965

98 Toolen letter to Shehan, April 2, 1965

99 Ibid.

100 Thomas Toolen Letter to Frank Westoff. April 26, 1965 ADMA, Box: 1965, File: W. 
letter to Archbishop Vagnozzi, Toolen explained:

Your Excellency, let us look at the other side of the picture. Rights bring obligations and responsibilities. These people have never heard of anything but rights. They do not, as a group, have the least idea of obligations and responsibilities. ${ }^{101}$

He also knew that supporting equality would bring severe financial repercussions, as the diocese's entire Negro apostolate depended upon the generosity of white patrons. "The story is told they don't support church or school because of irregularity of wages," wrote Toolen. "This is not true. They get equal wages with the white man in the South today."102 Toolen was convinced that the mission had profited from the publicity it had received during the demonstrations and was recklessly spending the money. In the fall of 1965 , Toolen wrote to Father Crowley and ordered the mission to pay off its standing debt. Toolen demanded, "After the windfall you had from the Selma demonstrations you ought to be able to pay at once and this I expect."103 Crowley informed the archbishop that while the mission did receive $\$ 10,000$ from Cardinal Spellman and $\$ 7,450$ from a special appeal by the Bishops of the United States, these were insufficient to cover even the operating expenses of the mission. "In fact," Crowley replied, "I wish the 1965 hospital operating deficit of $\$ 108,000.00$ was as fictitious as that windfall. Alas, it's a very factual item."104

101 Toolen letter to Shehan, April 2, 1965

102 Ibid.

103 Thomas J. Toolen Letter to John Crowley, September 11, 1965. ADMA, Box: 1965, File: C.

104 John Crowley Letter to Thomas Toolen, September 20, 1965 ADMA, Box: 1965, File: C. 
For Toolen, this was proof that blacks were simply not ready for equality. However, what troubled Toolen the most was the lack of deference to authority that the demonstrations and protests engendered. While civil rights were essential to a just society, so was the maintenance of proper social relationships. He lamented:

If you correct a Negro child today, if you criticize their way of life, if you speak of their disrespect for law and order, you are anti-Negro. They are a people apart on a pedestal. What we really need in our land is an organization for the protection of white people. 105

He ended his letter to Vagnozzi, "I have always had the reputation of being the friend of the Negro and I still have it and I want them to have their rights and justice, but they must do a great deal for themselves before they are ready for what they are seeking."106 Vagnozzi replied, "Let me say that I agree with Your Excellency that the participation of priests and nuns in such demonstrations should never have taken place without the consent of the local ordinary. However, I would make the observation that Father Ouellet's removal was perhaps untimely, but, be that as it may, Your Excellency certainly acted within his power."107

The National Catholic Reporter reported that since the demonstrations had ended, the archbishop had "repeatedly and openly stated that Father Ouellet

\footnotetext{
105 Thomas Toolen Letter to Edigo Vagnozzi. June 8, 1965. ADMA, Box: 1965, File: Apostolic Delegate.

106 Ibid.

107 Edigo Vagnozzi Letter to Thomas Toolen. July 23, 1965. (No. 381/35) Vagnozzi also notes a "complete report" on the issue. Vatican officials have not made this document available to scholars at the present time.
} 
must go because of his part in the demonstrations."108 Even non-Catholics were upset by the order. The African American newspaper the Chicago Defender awarded Toolen its "Onion for the Day" and stated:

Bending to the bigots in his Alabama Diocese, [Toolen] has moved to silence a voice which has been crying out for equality. Fr. Ouellet, who has been active in civil rights activities-- particularly voter registration for two years, administered to an almost total Negro parish. Though Alabama's civil rights battle will not be thwarted by such an undermining move, it will surely miss the leadership and inspiration of Fr. Ouellet. 109

Ouellet thought the decision was the result of financial pressure put on the bishop by white Catholics in the diocese. Of the order to leave, Ouellet recounted:

He said that I was a good priest, but that I was too wild on the racial question. But I never disobeyed one of his orders. I never demonstrated. I felt though like a man who had been allowed to walk out in the middle of a stream and then was forbidden to swim in either direction. ${ }^{110}$

While deeply upset, he did not appeal the action. Ouellet wrote a form letter to his friends and supporters announcing his transfer. He explained that the archbishop offered no specific reason for his decision, and he reiterated the fact that he "never disobeyed any order given me by the Bishop even though they may be contrary to my personal conviction." 111 The Society of St. Edmund unsuccessfully appealed Toolen's decision. The archbishop gave the order a choice: Ouellet or the mission. The order transferred Ouellet and assigned him

\footnotetext{
108 "Selma Pastor on Way Out" National Catholic Reporter, June 22, 1965.

109 "Raps Removal of Selma Cleric," Chicago Defender, June 28, 1965.

110 John Cogley, "Archbishop Ousts Priests at Selma," New York Times, June 26, 1965. "Selma Civil-Rights Priest is Transferred," Chicago Sun Times, June 27, 1965.

111 Maurice Ouellet to Matt Ahmann. August 22, 1965. NCCIJ Papers. Box: NCCIJ
} 
as the master of novices to the society's novitiate in Connecticut. In a letter to Ahmann informing the NCCIJ of his transfer he wrote, "When rebels are picked to train new men a new day has come!"112

In his farewell sermon on June 27, Ouellet asked that all his parishioners accept the change with dignity. Ouellet reminded his congregation that:

As a person and individual, I matter very little. However, the Church matters a great deal. There are those who might want to see the Church cease to be effective. I come, and I go. The Church remains, and you who make up the Church remain. God will not abandon you. And please, my people, make no mistake: I am not the Church. I go, but the Church goes on and the work goes on. ${ }^{113}$

Ouellet was a simple priest, and he submitted willingly to Toolen's order. His concern for the spiritual, physical and emotional well being of his congregation and his community far outweighed personal pride. In closing his sermon, he recounted many of the memories of his life in Selma. His last thought captured the very soul of the Catholic witness in Selma:

A song, a song to remember, a song so much more than just a melody, a song burned forever in this man's heart embodying the deep, agonizing, loving search of man's love for man. A song, challenge, a hope, and a faith. A song: WE SHALL OVERCOME. ${ }^{114}$

The song had been sung by Baptists, Methodists, Episcopalians, and Jews. Now it belonged to Catholics as well.

Correspondence, File: Ouellet.

112 Ibid.

113 Maurice Ouellet "Farewell Sermon," (27 June, 1965) NCCIJ Papers. Box: NCCIJ Correspondence, File: Ouellet.

114 Ibid. 
Once the throng of marchers had returned home and with them the threat of national media scrutiny, a segregationist backlash occurred. On August 20, a small demonstration was held in Fort Deposit, Alabama, a small town in Lowndes County, a few miles east of Selma. Thirty SNCC organizers were arrested and taken to the county seat in Haynesville where they were incarcerated for a week. The group was unexpectedly released eight days later. A few of the recently released SNCC demonstrators walked to the small general store in Haynesville to call the SNCC office in Selma and arrange a ride home. Jonathon Daniels, an episcopal seminarian from Keene, New Hampshire, and Father Richard Morrisroe, a Catholic priest from the St. Columbanus parish in Chicago, along with Ruby Sales and Joyce Bailey, attempted to enter the store to buy some sodas. Daniels had been in Selma for over a year. Morrisroe had marched in Selma and had returned to spend his summer break volunteering for SNCC. As they walked up the steps of Varner's Cash Store, the owner, Deputy Sheriff Tom Coleman, brandished a shotgun and ordered them off his property. As the group of SNCC workers retreated, Coleman fired. Daniels' was struck in the stomach and was killed instantly. Coleman fired a second time, striking Morrisroe in the back and seriously injuring him. Coleman then walked over to the courthouse and called the authorities to report the attack. ${ }^{115}$ The continuation of marches was widely debated among organizers. Many felt that a period of

\footnotetext{
115 Fager, Selma: 1965, 205-207. For more on Daniels' see Charles Eagles, Outside Agitators: Jon Daniel and the Civil Rights Movement in Alabama, University of North Carolina Press: Chapel Hill, 1993)
} 
cooling off was needed now that the right to vote had been secured with the passage of the Voting Rights Act. John Wright related the Haynesville incident in a letter to Sisters Alonzo in Rochester. "It is hard, I'm afraid, for some goodhearted people to realize," he wrote, "that by continuing the demonstrations they do more harm to the Negro's chances for progress now that they have the right to vote."116 There was some coverage of the killings and subsequent trial, but no massive outpouring of support or media attention.

The Selma demonstration highlights the importance of both the local and national structures of the Church to determine the reasons that Selma was such a lightning rod for Catholic involvement. While the Church has not always been at the forefront of the cause of racial justice, there have been those who made lasting contributions to the movement. Their legacy is the starting point for any discussion of Catholic participation. What Father LaFarge had begun in the early 1930s was directly responsible for the Church's familiarity with the issue of race in the 1960s. The efforts Catholic Interracial Councils, which championed the cause of interracial justice throughout the American Catholic community, provided the necessary organizational, theoretical and theological foundation for Catholic involvement in the direct action campaigns of the 1960s. The CICs espoused a theology, which declared the universal brotherhood in the mystical body of Christ, and created a national network of organizations and individuals dedicated to the cause of interracial justice. From a practical standpoint, CICs 
contacts with established civil rights organizations such as the NAACP and SCLC, and with emerging activists groups, such as SNCC, introduced Catholic activists to the philosophy of nonviolence and basic community organizing techniques.

The rise of the NCClJ signaled a new era of Catholic engagement in social issues, especially by Catholic laity. And while these activists remained "an effective minority," two major events occurred. Both the 1963 Conference on Race and Religion and the March on Washington were seminal events for Catholic interracial activists. These events enabled them to create an important network of contacts with major civil rights organizations and leaders, and, more importantly, to establish an institutional framework that would help them to muster a large Catholic presence on short notice. Prior to 1965, the Catholic interracial movement simply did not have the institutional resources in place to coordinate a massive undertaking.

In addition to the national development of the Catholic Interracial movement, the history of the St. Elizabeth's mission is an essential component of the history of the city of Selma. The importance of the mission as a haven for protest activity and bulwark against hostile white intimidation must not be underestimated. Although Catholics made up a small percentage of Selma's black community, they played a role in the movement far greater than their numbers suggest. The fathers of St. Edmund, the Sisters of St. Joseph and the

116 John Wright Letter to Sisters Alonzo, August 20, 1965. SSJA Selma Papers G13-1-1/Hospital- 
parishioners of the St. Elizabeth's mission labored to create a vibrant Catholic community within the strict confines of segregation. They were not concerned with a theoretical defense of inter-racialism, but with the practical needs of their parishioners. The religious, economic and social resources the mission was able to provide allowed SNCC organizers to initiate the Alabama Voting Rights Project. The mission also provided cover for both parishioners and employees of the mission to participate in the campaign. Father Ouellet's leadership inspired both his parishioners and the black community and helped to consolidate a fragmented local black leadership.

Of even greater importance was the dramatic shift in the public's perception of the civil rights movement, particularly after the Birmingham campaign of 1963. The profound change in public opinion forced many in the Church to question what role Catholics should play in the social revolution that was erupting in the South. At that time, numerous bishops and religious superiors radically changed their opinions about whether clergy should be allowed to participate in nonviolent demonstrations. However, bishops opposed to radical activity such as McIntyre and Toolen still posed formidable obstacles to major Catholic involvement. As the civil rights movement developed, Catholics, particularly Catholic activists, struggled to articulate a new vision. The decision by over half of the members of the Priests' Rights Committee to march in the Selma demonstrations highlights the rapid pace at which priests were redefining 
their role in social protest and their relationship to authority. The large presence of nuns at Selma is indicative of the strides Catholic women religious had taken as they sought to redefine their role in the Church and their place in the world.

And yet, despite the emergence of the NCCIJ onto the national scene and the grassroots involvement of Catholics in the Selma campaign, Catholics around the country were not drawn to participate in the movement in the Selma Voting Rights Campaign until March 7, 1965. It was the image of vicious state troopers beating unarmed black marchers and Martin Luther King's "Macedonian call" for clergy of goodwill that drew priests, nuns and laity from dioceses across the country. What distinguished the Selma movement from other civil rights campaigns was that for the first time the Catholic interracial movement was able to muster a large Catholic response. The NCCIJ amplified King's request throughout the Catholic community and, in concert with movement organizers and the staff of St. Elizabeth's, offered invaluable logistical assistance to those who wished to march. When protesters arrived, the St. Elizabeth's mission served as a safe haven, this time for visiting Catholics.

The Selma demonstration was the culmination of the Catholic interracial movement's attempts to involve the church in the struggle for interracial justice. Both Catholics and non-Catholics noted the impressive numbers the Church had turned out. Ralph McGill, editor of the Atlanta Constitution, wrote:

The Roman Catholic Church has not been without its failures, but more than any other single division of the Christian faith it has, from Vatican to the 
lowliest priests and nun, been more forthright in its participation and pronouncements against racial injustice than any other group. ${ }^{117}$

And Catholics who had participated pointed to the demonstrations as an indication that the Church was transformed. Of the hundreds of Catholics who had joined the marches, Ouellet recounted:

It meant that the Catholic Church, at least at the grass roots level was on our side too-- which [the movement] needed to hear. The official Church still kept its distance, but de facto, as far as the civil rights movement was concerned, priests and nuns were there, and that is the Catholic Church. ${ }^{118}$

Father Crowley echoed those feelings. "Now at last," he said, "this great outpouring of priests and nuns has marked officially, indelibly and forever the stand for racial justice the church has taken over many, many years. So many people-- so many Catholics-- have never understood it. Now no one can fail to identify it."119

The Catholic Church provided the campaign with a fresh new symbol of Christian witness, particularly in the case of women religious, and the massive influx of Catholics infused the campaign with a renewed sense of moral legitimacy, as the last of the mainstream American churches aligned itself with the struggle for equal rights. Their presence forced SCLC and SNCC to construct with a new operational paradigm as they struggled to incorporate their new partners effectively into the movement. Catholics had been extremely selfconscious of themselves as outsiders in a Protestant world, and had often

117 Ralph McGill, "The Agony of the Church," Atlanta Constitution, March 14, 1965.

118 Ouellet Interview.

119 Alice Burke, “Unsung Heroes Stay on the Job," St. Michael's Review, Spring 196514. 
avoided confrontations with the status quo for fear of inviting economic, political and social retribution. Selma marked a break with the Church's cautious past and inaugurated the beginning of concerted action in dealing with political, social and moral problems. For the Catholic Church, Selma is the watershed that divides a period of sporadic and indecisive activity and one of intense immersion into contemporary social problems. This change was most clearly illustrated by the fact that most marchers ignored the tradition requiring permission from the local bishop to perform public acts.

Those who rejoiced at "the presence of the Church" misread the scene. What Ouellet, Crowley and others saw as indicative of a definitive Catholic presence was, in fact, the participation of the men and women who had been involved in the interracial justice movement or African American evangelization for years. While there were Catholics who had not heretofore been involved in the interracial apostolate, there was no mass conversion to the cause of interracial justice. Instead there was a sense of confidence that allowed those Catholic clergy, religious and laity to stand up and give witness for Catholic ideals in a new way. Rather than heralding a change in the nature of Catholic social engagement, the demonstrations denote a change in public perception, and specifically Catholic self-perception, of the role of the Church in radical social activism. The men and women who traveled to Selma saw themselves as engaging in a pilgrimage. The word pilgrimage is an apt metaphor for the event as pilgrimages are made by the faithful to reestablish their connection to the 
sacred.

Catholic interracial activists for over three decades had espoused a notion of brotherhood and equality modeled on the Mystical Body of Christ. This vision of the perfect society in many ways mirrored King's notion of the Beloved Community. Catholics were well aware of the obstacles facing such a racial reconciliation. As Selma veteran Father Philip Berrigan, S.S.J., explained, "I would be risking grave dishonesty if I said that Catholics or other Christians are making mighty progress in realizing for their Negro brothers the practicalities of justice and charity." 120 Ironically, Catholics joined the movement just as it began the transition to a new phase of the struggle. Following the march, the civil rights movement fragmented, as the very nature of the struggle was radically altered.

Fred Powledge described the Selma movement as "the last great demonstration" of the movement in which the last vestiges of overt legal discrimination were defeated. He continued:

Of course the Movement was not over. But an important moment had been passed. The march was one of the last gatherings of the original civil rights movement. Now the groups that together formed the Movement moved further and further apart. The crusade against discrimination went on, but in different ways, at different tempos, with different aims and agendas. The original campaign-- the movement of Brown, of Montgomery, of Greensboro, of soul force and satyagraha, of Anniston and Birmingham-was ending. "Never" had died' the long haul was here. The real revolution had begun. ${ }^{121}$

The coalition that emerged during the Selma demonstrations was an uneasy alliance of white Northern liberals entering the movement for the first time and 
hardened black activists who had spent years on the front lines. Martin

Luther King's personal advisor Stanley Levinson explained:

The coalition of Selma and Montgomery, with its supporting millions, is not a coalition with an unrestricted program. It is a coalition around a fairly narrow objective ... It is basically a coalition for moderate change, for gradual improvements which are to be attained without excessive upheavals as it generally alters old patterns. It is militant only against shocking violence and gross injustice. It is not for deep radical change. ${ }^{122}$

Just as Catholics actively entered into the movement, this vision of an integrated society was under assault by disillusioned black movement veterans who began to ask for a great deal more than simply "justice and charity." Nor were these leaders willing to abstain from violence. ${ }^{123} \mathrm{~A}$ few months after the final march to Montgomery the cry of black power startled many recent arrivals and fractured the nascent coalition.

The decision by SCLC to initiate a campaign in Chicago the following year also eroded Catholic support for the movement. After Selma, the civil rights movement would not be presented with another venue in which to stage a morality play, where the forces of good would be so clearly aligned against the forces of evil. Catholic interracial activists left Selma and went back North, where the nature of the struggle was much less well defined. Monsignor John Egan, Monsignor Daniel Cantwell, John McDermott and other Catholic organizers were completely unprepared for the violent and vehement response of Catholic laity to the marchers. The "open housing" marches in the community of Cicero, Illinois

121 Powledge, Free at Last, 630.

122 Levinson quoted in Garrow, Bearing the Cross, 
brought out angry mobs of Catholic laity who hurled insults, racial epithets and bricks at priests, nuns and blacks. Whereas roman collars and habits had offered a modicum of protection in Selma, the sight of them incited the crowd to even greater violence in the North. ${ }^{124}$ McDermott recalled, "The scores of nuns and priests who marched became special targets. Spectators yelled, "You're not a real priest," "Hey, Father, are you sleeping with her?"125 Catholic activists in Albany, Baltimore, Boston, Detroit, Philadelphia, Milwaukee and New York, who hoped to push forward reform on the heels of the Selma demonstrations, found deep-seated resistance to their efforts. Residents of these Northern ethnic Catholic enclaves were convinced that the entrance of African Americans into their parishes would inevitably lead to their destruction. 126 On February 22, 1966, Ted Sorensen spoke at the Chicago CIC's annual John F. Kennedy awards banquet. The award was given to Father Richard Morrisroe who was still recovering from the gun shot wound he sustained in Haynesville six months earlier. Of the movement's migration north, Sorensen stated:

It was easier in fact, to march at Selma last year than it is to admit that this problem is not just the South's or the Nation's, or even the Mayor's or the School Board's, but ours-- our problem-- and we white liberals are part of the Negro's problem. As this issue moves rapidly from South to North, the pressures on our Northern Churches are going to increase-- pressure from parishioners who want no Negroes in the neighborhood- pressures from important contributors and important church leaders and important

123 On the rise of black power see Garrow, Bearing the Cross, 481. Clayborne Carson,

124 McGreevey, John, Parish Boundaries, 189-190.

$125 \mathrm{Ibid}, 189$.

126 Ibid, 192-197. 
politicians. Then will be tested the courage and commitment of your churches far more than they were tested in far-off Selma. ${ }^{127}$

For Catholics in the North, the issue of race was clouded by religion and ethnicity, segregation was de facto not de jure and the antagonists and protagonists were neighbors, parishioners and fellow priests. ${ }^{128}$ Once again the issue was not "Catholic racialism in theory but Catholic racialism in practice."129

Catholic participation at Selma heralded what seemed to be an explosion of Catholic involvement in numerous social and political issues. The appeal to personal conscience as a valid justification for participation in social activism opened up the possibility for clergy and religious involvement in a host of social issues. It marked the birth in the popular mind of the "radical priest," as clergy became familiar faces on picket lines. ${ }^{130}$ As Catholics adopted the lessons of nonviolence and the language of rights, they organized other causes--- the antiwar, the woman's, free speech, migrant labor, la raza and sanctuary movements. Philip and Daniel Berrigan became leaders of anti-war protests. Philip eventually married while still a priest and left the Church. Father Geno Baroni became a key community organizer in the neighborhood around his Washington, D.C. parish and eventually served as the Assistant Secretary for Housing and Urban Development in the Carter Administration. Father James Groppi led numerous

127 Ted Sorensen, CIC Award's Banquet Speech, February 22, 1966. CHS Chicago CIC Papers. 128 For more on Catholic involvement in the Civil Rights movement in the Chicago see Alan Anderson and George Pickering, Confronting the Color Line: The Broken promises of the Civil Rights Movement in Chicago, University of Georgia Press: Athens, 1986 and McGreevey, Parish Boundaries.

129 McGreevey, Parish Boundaries, 33. 
open housing marches in Milwaukee. ${ }^{131}$ Father Sherrill Smith was active in the migrant labor movements in Texas. Sisters Mary Peter, S.S.N.D., like many Sisters, reverted to her original name. She continued her work on the South Side of Chicago and her involvement with the Sisters Formation Movement. But the presence of Catholics in these movements also pointed to the deep divisions that existed in the Church and Catholic society as a whole. Catholics challenged the hierarchical nature of the Church itself particularly on the issues of birth control, celibacy, the ordination of women and liturgical reform. In the late 1960s numerous African American priests and laity adopted the language of black power and challenged the very nature of the Church itself. In 1968 a group of black priests, including Selma veterans Fathers George Clements and John Lucas, formed the Black Catholic Clergy Caucus and charged that the Church was essentially a "white racist institution." 132 By the late 1960s American Catholics were no longer a people set apart, rather they were fully engaged with the full range of issues and causes, just as likely to criticize the status quo as defend it.

The role that Catholics played in the Selma campaign was by no means a dominant one, but it was an important one. Examining the interaction of American Catholics and the civil rights movement on both the local and national level, adds much needed depth, color and dimension to the historical narrative. It

130 Jay Dolan, American Catholic Experience, 447

131 On Groppi's activities see McGreevey, Parish Boundaries, 198-205.

132 See Davis, History of Black Catholics, 257-9 
expands our understanding of the full range of resources that the African American community was able to draw upon in the struggle for civil rights and enables us to assess its impact and offers us insight into the ways in which the Black freedom struggle was able to integrate itself into the American mainstream. Finally, it allows us to explore the effects the movement had on the Church as it struggled to reappraise its place in a changing America. 